\title{
METAL FILTERS FOR PRESSURIZED FLUID BED COMBUSTION (PFBC) APPLICATIONS
}

\author{
Final Report \\ DOE/NETL Contract No. DE-AC26-98FT40002
}

January 2, 2004

\author{
by \\ M. A. Alvin \\ Siemens Westinghouse Power Corporation \\ Science and Technology Center \\ 1310 Beulah Road \\ Pittsburgh, PA 15235-5098
}

\author{
Prepared for \\ U.S. Department of Energy \\ National Energy Technology Laboratory \\ 626 Cochrans Mill Road \\ P.O. Box 10940 \\ Pittsburgh, PA 15236-0940
}

R. Dunst and T. J. McMahon - DOE/NETL Project Manager 


\section{DISCLAIMER}

This report was prepared as an account of work sponsored by the United States Government. Neither the United States nor the United States Department of Energy, nor any of their employees, makes any warranty, expressed or implied, or assumes any legal liability or responsibility for the accuracy, completeness, or usefulness of any information, apparatus, product, or process disclosed, or represents that its use would not infringe privately owned rights. herein to any specific commercial product, process, or service by trade name, mark, manufacturer, or otherwise, does not necessarily constitute or imply its endorsement, recommendation, or favoring by the United States Government or any agency thereof. The views and opinions of authors expressed herein do not necessarily state or reflect those of the United States Government or any agency thereof. 


\begin{abstract}
Advanced coal and biomass-based gas turbine power generation technologies (IGCC, PFBC, PCFBC, and Hipps) are currently under development and demonstration. Efforts at the Siemens Westinghouse Power Corporation (SWPC) have been focused on the development and demonstration of hot gas filter systems as an enabling technology for power generation. As part of the demonstration effort, SWPC has been actively involved in the development of advanced filter materials and component configuration, has participated in numerous surveillance programs characterizing the material properties and microstructure of field-tested filter elements, and has undertaken extended, accelerated filter life testing programs. This report reviews SWPC's material and component assessment efforts, identifying the performance, stability, and life of porous commercial metal, advanced alloy, and intermetallic filters under simulated, pressurized fluidized-bed combustion (PFBC) conditions.
\end{abstract}




\section{LIST OF ACRONYMS}

\section{DOE \\ EDX \\ in-wg \\ PCFBC \\ PFBC \\ NETL \\ SEM \\ STC \\ SWPC \\ USF}

\author{
Department of Energy \\ Energy dispersive $\mathrm{x}$-ray analysis \\ Inches water gauge \\ Pressurized circulating fluidized-bed combustion \\ Pressurized fluidized-bed combustion \\ National Energy Technology Laboratory \\ Scanning electron microscopy \\ Science and Technology Center \\ Siemens Westinghouse Power Corporation \\ U.S. Filter/Fluid Dynamics
}




\section{TABLE OF CONTENTS}

\section{ABSTRACT}

EXECUTIVE SUMMARY

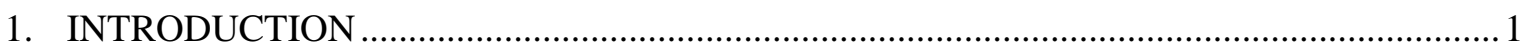

1.1 Program Overview and Filter Element Construction..................................................... 1

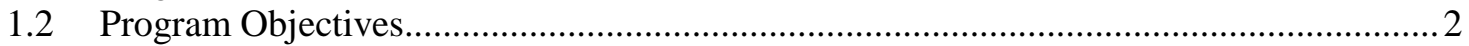

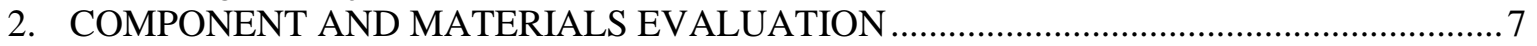

2.1 Room Temperature Gas Flow Resistance Measurements............................................. 7

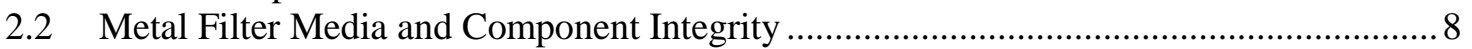

2.3 Mechanical Properties — Process Temperature Tensile Strength ................................... 8

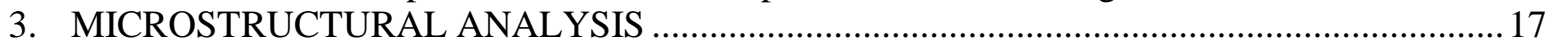

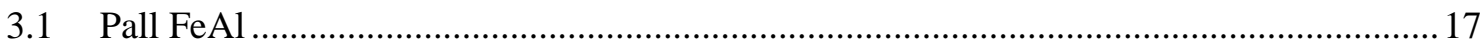

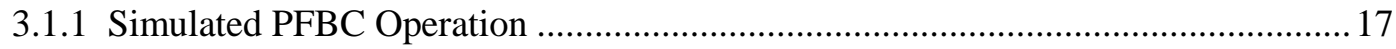

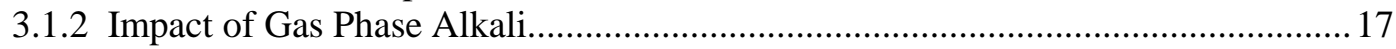

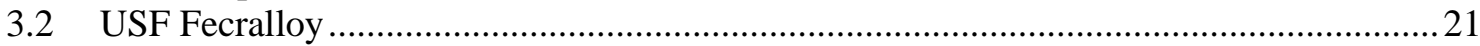

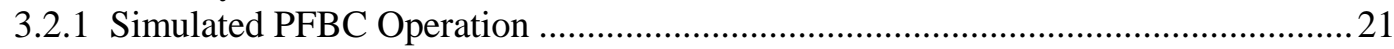

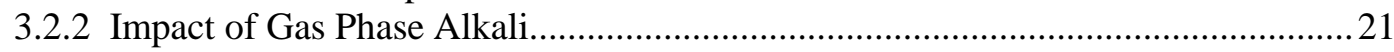

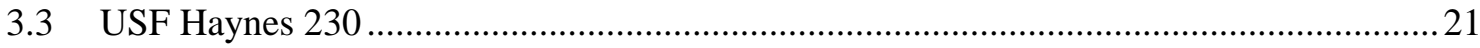

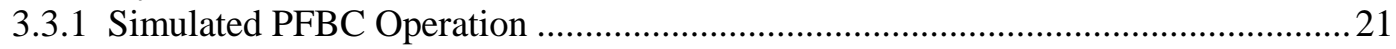

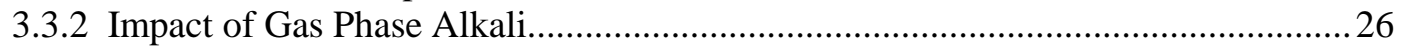

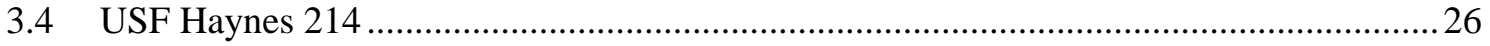

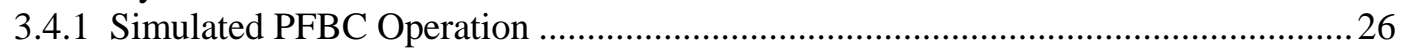

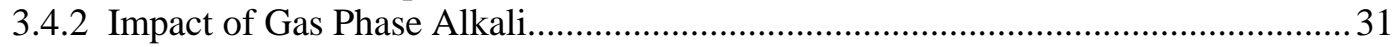

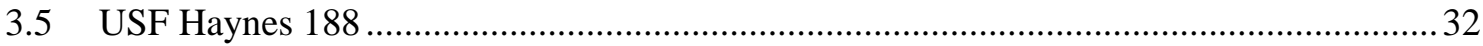

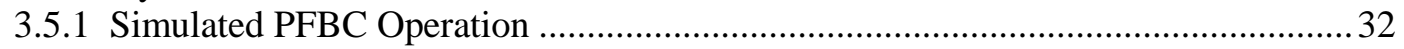

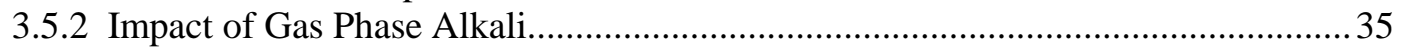

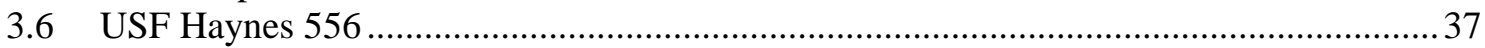

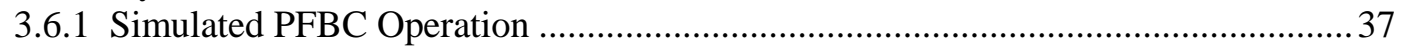

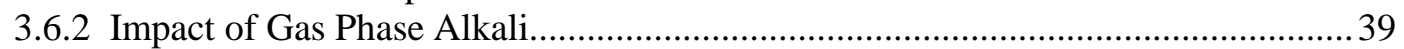

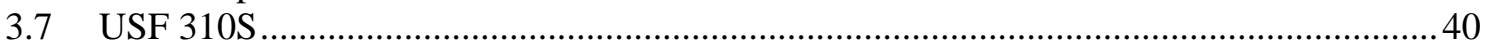

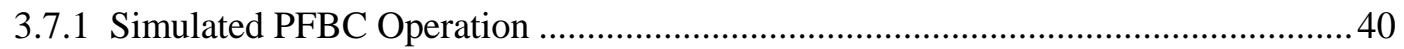

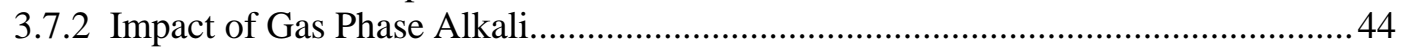

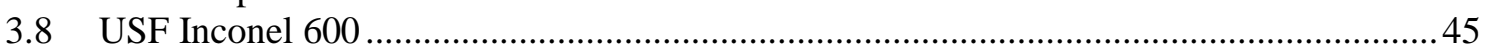

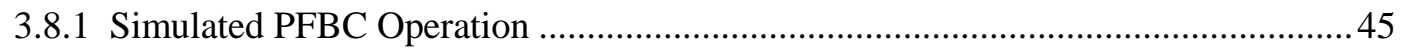

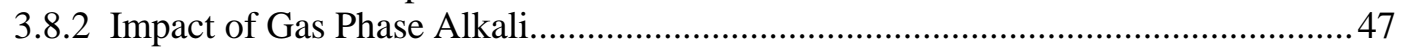

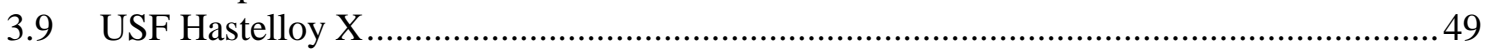

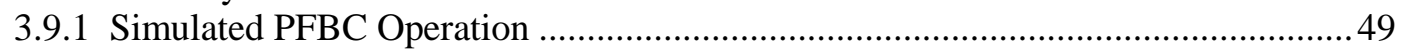

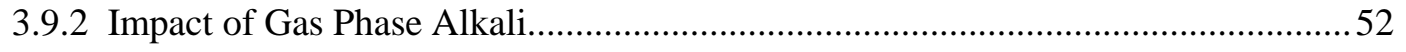

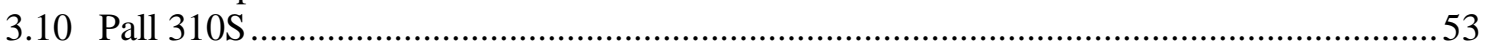

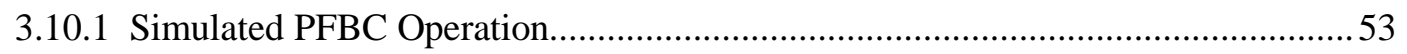

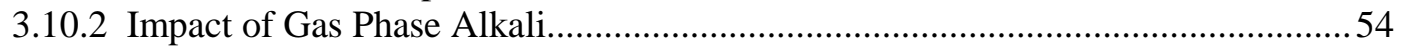

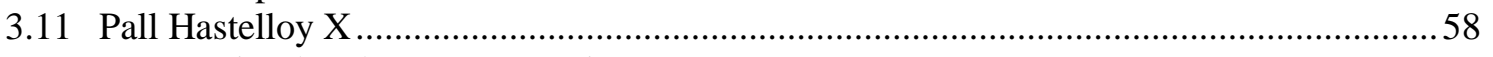

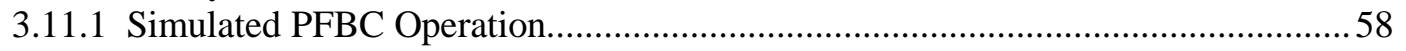

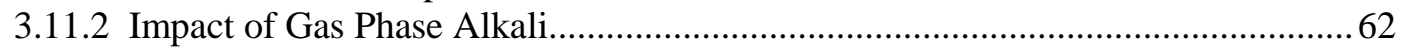

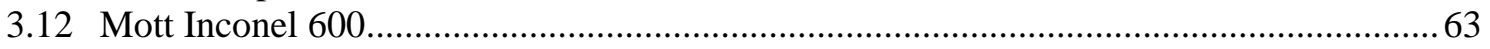




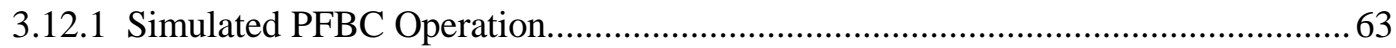

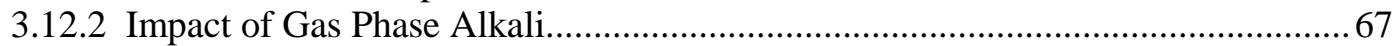

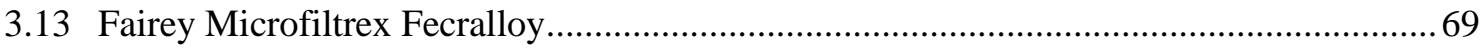

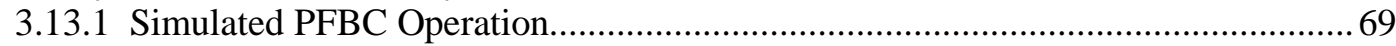

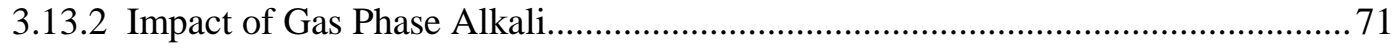

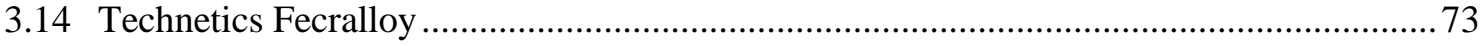

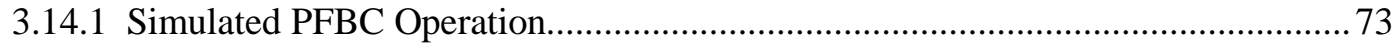

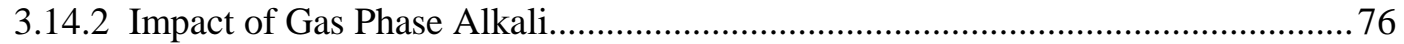

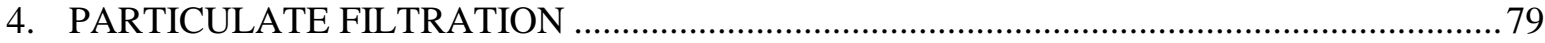

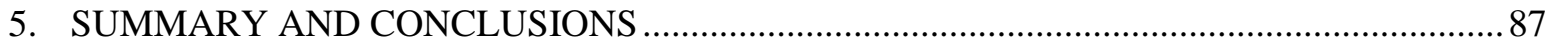

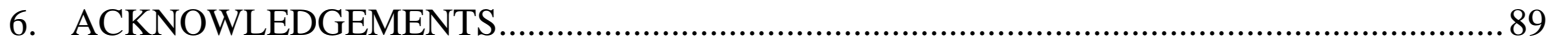

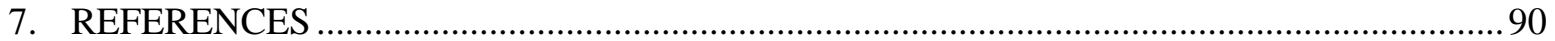

APPENDIX A - Summary of Metal Filter Media Stability under Simulated PFBC Operating Conditions 


\section{TABLES}

1. Developmental and Commercially Available Metal Filter Media ......................................... 1

2. Metal Filter Elements - Component Architecture and Materials of Construction.................. 3

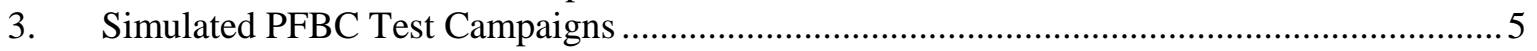

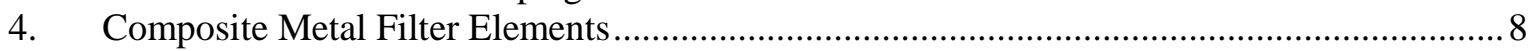

5. Metal Filter Media and Component Physical Integrity .................................................. 9

6. Candle Filter Array — Steady State, Accelerated Pulse Cycling and Thermal Transient

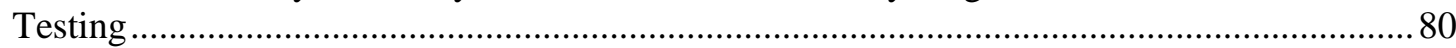

7. Candle Filter Array — High Temperature Corrosion Testing …........................................... 82

8. Recommended Use of Metal Filter Elements in PFBC Applications .....................................87 


\section{FIGURES}

1. Metal filters for PFBC and PCFBC applications 1

2. Porous, sinter bonded, fibrous, USF filter metal media. (a) Composite architecture; (b) Cross-sectioned filtration media wall; (c) External filtration surface; (d) Internal structural mesh surface. 4

3. Composite metal filter array used in SWPC STC PFBC simulator testing.......................... 6

4. Room temperature gas flow resistance measurements of as-manufactured, porous, metal

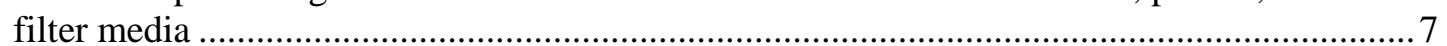

$5 \quad$ Failure of porous metal filter media during simulated PFBC operation ................................ 10

6. Process temperature tensile strength of the iron-based, intermetallic and advanced alloy, porous filter media after exposure to simulated PFBC operating conditions ............................13

7. Process temperature tensile strength of the iron-based, advanced and commercial alloy, porous filter media after exposure to simulated PFBC operating conditions ............................ 14

8. Process temperature tensile strength of the nickel-based, commercial alloy, porous filter media after exposure to simulated PFBC operating conditions ........................................... 15

9. Process temperature tensile strength of the nickel and cobalt-based, advanced alloy, porous filter media after exposure to simulated PFBC operating conditions...

10. Microstructure of the porous Pall FeAl filter media after 500 hours of operation in the $650^{\circ} \mathrm{C}\left(1200^{\circ} \mathrm{F}\right)$ simulated $\mathrm{PFBC}$ process gas environment.

11. Microstructure of the porous Pall FeAl filter media after 258-1016 hours of operation in the $760^{\circ} \mathrm{C}\left(1400^{\circ} \mathrm{F}\right)$ and $840^{\circ} \mathrm{C}\left(1550^{\circ} \mathrm{F}\right)$ simulated $\mathrm{PFBC}$ process gas environment.....

12. Failure of the Pall FeAl filter element sections after 225 hours of exposure in the $840^{\circ} \mathrm{C}$ $\left(1550^{\circ} \mathrm{F}\right)$ simulated $\mathrm{PFBC}$ process gas environment containing gas phase sulfur and alkali... 19

13. Accelerated oxidation of the Pall FeAl filter media after 225 hours of exposure in the $840^{\circ} \mathrm{C}\left(1550^{\circ} \mathrm{F}\right)$ simulated PFBC process gas environment containing gas phase sulfur and alkali

14. Morphology of the USF Fecralloy filter media after exposure to $650-840^{\circ} \mathrm{C}\left(1200-1550^{\circ} \mathrm{F}\right)$ simulated PFBC operating conditions

15. Morphology of the USF Fecralloy filtration media after exposure to $840^{\circ} \mathrm{C}\left(1550^{\circ} \mathrm{F}\right)$ simulated PFBC operating conditions containing gas phase sulfur and alkali........................23

16. Morphology of the USF Haynes 230 filter media after exposure to $650-840^{\circ} \mathrm{C}(1200-$

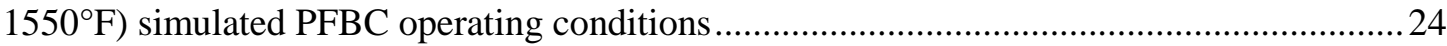

17. Morphology of the USF Haynes 230 filtration media after exposure to $840^{\circ} \mathrm{C}\left(1550^{\circ} \mathrm{F}\right)$ simulated PFBC operating conditions containing gas phase sulfur and alkali..... 27

18. Morphology of the USF Haynes 214 filtration media after 500 hours of operation in the

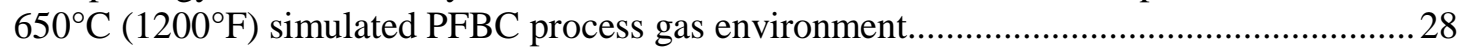

19. Morphology of the USF Haynes 214 filtration media after 258 hours of operation in the $760^{\circ} \mathrm{C}\left(1400^{\circ} \mathrm{F}\right)$ simulated $\mathrm{PFBC}$ process gas environment.

20. Micrograph montage illustrating the morphology of the $760^{\circ} \mathrm{C}\left(1400^{\circ} \mathrm{F}\right) \mathrm{USF}$ Haynes 214 filtration media after 1016 hours of operation in the simulated PFBC process gas environment.

21. Morphology of the USF Haynes 214 filtration media after operation in the $815-840^{\circ} \mathrm{C}$

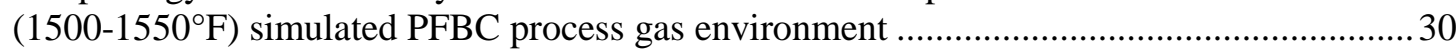

22. Morphology of the USF Haynes 214 filtration media after 1014 hours of operation in the $840^{\circ} \mathrm{C}\left(1550^{\circ} \mathrm{F}\right)$, sulfur-free, simulated $\mathrm{PFBC}$ process gas environment. 
23. Morphology of the extensively oxidized USF Haynes 214 fibers after 496 hours of operation in the $840^{\circ} \mathrm{C}\left(1550^{\circ} \mathrm{F}\right)$ simulated PFBC process gas environment that contained

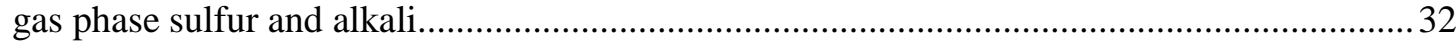

24. Morphology of the USF Haynes 188 filtration media after 500 hours of operation in the

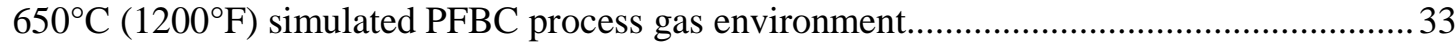

25. Impact of PFBC operating temperature and time on the morphology of the USF Haynes filtration media

26. Micrographs illustrating extensive external and internal oxidation that resulted along the surface and throughout the $840^{\circ} \mathrm{C}\left(1550^{\circ} \mathrm{F}\right)$, sulfur-free, simulated PFBC-exposed, USF Haynes 188 filtration media

27. USF Haynes 188 filtration media filter media after operation in the $840^{\circ} \mathrm{C}\left(1550^{\circ} \mathrm{F}\right)$ simulated PFBC process gas environment containing gas phase sulfur and alkali 36

28. Extensive oxidation, as well as removal of the oxide formation along the external surface of the USF Haynes 188 fibers after 225 hours of operation in the $840^{\circ} \mathrm{C}\left(1550^{\circ} \mathrm{F}\right)$, gas phase sulfur and alkali-containing, simulated PFBC process gas environment ..................................36

29. Morphology of the USF Haynes 556 filtration media after operation in the $650^{\circ} \mathrm{C}\left(1200^{\circ} \mathrm{F}\right)$ simulated PFBC process gas environment.

30. Impact of PFBC operating temperature and time on the morphology of the USF Haynes

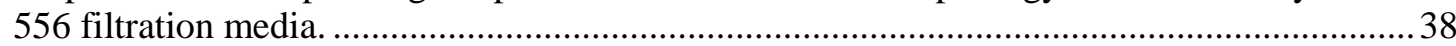

31. Morphology of the USF Haynes 556 filtration media after 1014 hours of operation in the sulfur-free, $840^{\circ} \mathrm{C}\left(1550^{\circ} \mathrm{F}\right)$, simulated $\mathrm{PFBC}$ process gas environment.

32. Extensive oxidation of the USF Haynes 556 filtration media after operation in the $840^{\circ} \mathrm{C}$ $\left(1550^{\circ} \mathrm{F}\right)$, gas phase sulfur and alkali-containing, simulated PFBC process gas environment...

33. Microstructure of the USF $310 \mathrm{~S}$ filtration media after operation in the $650^{\circ} \mathrm{C}\left(1200^{\circ} \mathrm{F}\right)$ simulated PFBC process gas environment

34. Microstructure of the USF 310 S filtration media after 1016 hours of operation in the $760^{\circ} \mathrm{C}$ $\left(1400^{\circ} \mathrm{F}\right)$ simulated $\mathrm{PFBC}$ process gas environment.

35. Morphology of the cross-sectioned, 986 hour, $815-840^{\circ} \mathrm{C}\left(1500-1550^{\circ} \mathrm{F}\right)$, simulated PFBCexposed, USF 310 S filtration media.

36. Morphology of the USF 310 S filtration media after operation in the sulfur-free, $840^{\circ} \mathrm{C}$ $\left(1550^{\circ} \mathrm{F}\right)$, simulated $\mathrm{PFBC}$ process gas environment.

37. Morphology of the USF 310 S filtration media after operation in the $840^{\circ} \mathrm{C}\left(1550^{\circ} \mathrm{F}\right)$ simulated PFBC process gas environment that contained gas phase sulfur and alkali .............44

38. Morphology of the USF Inconel 600 filtration media after 500 hours of operation in the $650^{\circ} \mathrm{C}\left(1200^{\circ} \mathrm{F}\right)$ simulated $\mathrm{PFBC}$ process gas environment.

39. Morphology of the USF Inconel 600 filtration media after operation in the $760^{\circ} \mathrm{C}\left(1400^{\circ} \mathrm{F}\right)$ simulated PFBC process gas environment

40. Microstructure of the USF Inconel 600 filtration media after 986 hours of operation in the $815-840^{\circ} \mathrm{C}\left(1500-1550^{\circ} \mathrm{F}\right)$ simulated $\mathrm{PFBC}$ process gas environment.

41. Morphology of the USF Inconel 600 filtration media after 1014 hours of operation in the sulfur-free simulated PFBC process gas environment

42. Microstructure of the USF Inconel 600 filtration media after operation in the $840^{\circ} \mathrm{C}$ $\left(1550^{\circ} \mathrm{F}\right)$ simulated $\mathrm{PFBC}$ process gas environment that contained gas phase sulfur and alkali

43. Morphology of the USF Hastelloy X sinter bonded filtration media after 242 and 500 hours of operation in the $650^{\circ} \mathrm{C}\left(1200^{\circ} \mathrm{F}\right)$ simulated PFBC process gas environment

44. Morphology of the USF Hastelloy X filtration media after 258-1016 hours of operation in the $760^{\circ} \mathrm{C}\left(1400^{\circ} \mathrm{F}\right)$ simulated $\mathrm{PFBC}$ process gas environment....

45. Morphology of the sinter bonded USF Hastelloy $\mathrm{X}$ fibers as a result of operation in the $815-840^{\circ} \mathrm{C}\left(1500-1550^{\circ} \mathrm{F}\right)$ simulated $\mathrm{PFBC}$ process gas environment. 
46. Microstructure of the USF Hastelloy X filtration media after operation in the sulfur-free simulated PFBC process gas environment...

47. Morphology of the USF Hastelloy $\mathrm{X}$ filtration media after operation in the $840^{\circ} \mathrm{C}\left(1550^{\circ} \mathrm{F}\right)$ simulated PFBC process gas environment that contained gas phase sulfur and alkali ............52

48. Morphology of the Pall $310 \mathrm{~S}$ filtration media after operation in the $650^{\circ} \mathrm{C}\left(1200^{\circ} \mathrm{F}\right)$ simulated PFBC process gas environment.

49. Morphology of the Pall $310 \mathrm{~S}$ filtration media after 258 hours of operation in the $760^{\circ} \mathrm{C}$ $\left(1400^{\circ} \mathrm{F}\right)$ simulated $\mathrm{PFBC}$ process gas environment.

50. Fracture characteristics of the Pall $310 \mathrm{~S}$ filtration media at $\geq 650^{\circ} \mathrm{C}\left(\geq 1400^{\circ} \mathrm{F}\right)$ simulated PFBC operating temperatures

51. Morphology of the Pall $310 \mathrm{~S}$ filtration media after 225 hours of operation in the $840^{\circ} \mathrm{C}$ $\left(1550^{\circ} \mathrm{F}\right)$, gas phase sulfur and alkali-containing, simulated PFBC process gas environment (o.d. surface).

52. Higher magnification micrographs illustrating the thickness and morphology of the oxide layer that formed along the outer surface of the 225 hour, $840^{\circ} \mathrm{C}\left(1550^{\circ} \mathrm{F}\right)$, gas phase sulfur and alkali-containing, simulated PFBC-exposed, sinter bonded, Pall 310S particles (o.d. surface)

53. Higher magnification micrographs illustrating the extensive surface and internal oxidation that resulted along and within the sinter bonded Pall 310S particles after 225 hours of operation in the $840^{\circ} \mathrm{C}\left(1550^{\circ} \mathrm{F}\right)$, gas phase sulfur and alkali-containing, simulated PFBC process gas environment.

54. Morphology of the cross-sectioned, sinter bonded, Pall 310S particles along the mid-section of the 225 hour, $840^{\circ} \mathrm{C}\left(1550^{\circ} \mathrm{F}\right)$, gas phase sulfur and alkali-containing, simulated PFBCexposed, filter wall

55. Morphology of the Pall Hastelloy X filtration media after 242 hours of operation in the $650^{\circ} \mathrm{C}\left(1200^{\circ} \mathrm{F}\right)$ simulated PFBC process gas environment

56. Microstructure of the Pall Hastelloy X filtration media after 258 hours of operation in the $760^{\circ} \mathrm{C}\left(1400^{\circ} \mathrm{F}\right)$ simulated PFBC process gas environment. (a) o.d. surface; (b) Midsection; (c) Pulse cycled or i.d. surface

57. Micrograph illustrating the morphology of the Pall Hastelloy X filter media after 524.5 hours of $760^{\circ} \mathrm{C}\left(1400^{\circ} \mathrm{F}\right)$ simulated PFBC operation.

58. Morphology of the Pall Hastelloy X filter media along the (a) o.d. surface and (b) i.d. or pulse cycled surface of the filter element after 1016 hours of operation in the $760^{\circ} \mathrm{C}$ $\left(1400^{\circ} \mathrm{F}\right)$ simulated $\mathrm{PFBC}$ process gas environment.

59. Oxide formation along the outer surface of the Pall Hastelloy $\mathrm{X}$ sinter bonded particles after 259 and 986 hours of operation in the $815-840^{\circ} \mathrm{C}\left(1500-1550^{\circ} \mathrm{F}\right)$ simulated PFBC process gas environment .....

60. Morphology of the Pall Hastelloy X filter media after 1014 hours of operation in the $840^{\circ} \mathrm{C}$ $\left(1550^{\circ} \mathrm{F}\right)$ simulated $\mathrm{PFBC}$ process gas environment.....

61. Micrographs illustrating the formation of cracks and separation of the oxide layers along the outer surface of the sinter bonded Pall Hastelloy X particles after 253, 546.5, and 1014 hours of exposure in a sulfur-free simulated PFBC process gas environment

62. Morphology of the as-manufactured Mott Inconel 600 filtration media.

63. Morphology of the Mott Inconel 600 filtration media after 242 and 500 hours of operation in the $650^{\circ} \mathrm{C}\left(1200^{\circ} \mathrm{F}\right)$ simulated $\mathrm{PFBC}$ process gas environment.

64. Morphology of the Mott Inconel 600 filtration media after 258 and 1016 hours of operation in the $760^{\circ} \mathrm{C}\left(1400^{\circ} \mathrm{F}\right)$ simulated $\mathrm{PFBC}$ process gas environment

65. Morphology of the Mott Inconel 600 filtration media after 259 and 986 hours of operation in the $815-840^{\circ} \mathrm{C}\left(1500-1550^{\circ} \mathrm{F}\right)$ simulated PFBC process gas environment.

66. Morphology of the Mott Inconel 600 filtration media after 253 and 1014 hours of operation in the $840^{\circ} \mathrm{C}\left(1550^{\circ} \mathrm{F}\right)$, sulfur-free, simulated PFBC process gas environment. 
67. Morphology of the Mott Inconel 600 filtration media after 225 and 496 hours of operation in the $840^{\circ} \mathrm{C}\left(1550^{\circ} \mathrm{F}\right)$ simulated PFBC process gas environment that contained gas phase sulfur and alkali

68. Micrographs illustrating the morphology of the cross-sectioned Mott Inconel 600 media along the mid-section of the filter wall after 496 hours of exposure in the $840^{\circ} \mathrm{C}\left(1550^{\circ} \mathrm{F}\right)$ simulated PFBC process gas environment containing gas phase sulfur and alkali ..................68

69. Morphology of the as-manufactured Fairey Microfiltrex filtration media.

70. Morphology of the sinter bonded Fairey Microfiltrex Fecralloy fibers after 500 hours of operation in the $650^{\circ} \mathrm{C}\left(1200^{\circ} \mathrm{F}\right)$ simulated PFBC process gas environment. (a) Outer surface fibers; (b) Inner surface fibers

71. Microstructure of the Fairey Microfiltrex Fecralloy fibers after 1016 hours of operation in the $760^{\circ} \mathrm{C}\left(1400^{\circ} \mathrm{F}\right)$ simulated PFBC process gas environment.

72. Microstructure of the Fairey Microfiltrex Fecralloy fibers after 986 hours of operation in the $815-840^{\circ} \mathrm{C}\left(1500-1550^{\circ} \mathrm{F}\right)$ simulated $\mathrm{PFBC}$ process gas environment.....

73. Densification of the outer surface of the Fairey Microfiltrex filter element section that contained the fine Fecralloy fibers after 225 hours of operation in the $840^{\circ} \mathrm{C}\left(1550^{\circ} \mathrm{F}\right)$, sulfur and alkali-containing, simulated PFBC process gas environment

74. Morphology of the coarse Fecralloy fibers contained within the Fairey Microfiltrex filtration media after 225 hours of operation in the $840^{\circ} \mathrm{C}\left(1550^{\circ} \mathrm{F}\right)$ simulated PFBC process gas environment that contained gas phase sulfur and alkali.

75. Morphology of the as-manufactured Technetics Fecralloy filter media. ............................... 74

76. High magnification micrographs illustrating the thickness and morphology of the oxide layer that formed along the outer surface of the cross-sectioned Fecralloy fibers contained within the 1016 hour, $760^{\circ} \mathrm{C}\left(1400^{\circ} \mathrm{F}\right)$, simulated PFBC-exposed, Technetics filtration media

77. Microstructure of the Technetics Fecralloy filtration media as a result of operation in the $815-840^{\circ} \mathrm{C}\left(1500-1550^{\circ} \mathrm{F}\right)$ simulated PFBC process gas environment.

78. Morphology of the Technetics Fecralloy filtration media after 225 hours of operation in the $840^{\circ} \mathrm{C}\left(1550^{\circ} \mathrm{F}\right)$ simulated PFBC process gas environment containing gas phase sulfur and alkali

79. Higher magnification micrograph illustrating extensive surface and internal oxidation of the Fecralloy fibers that were present along the outer surface of the Technetics filtration media after 496 hours of operation in the $840^{\circ} \mathrm{C}\left(1550^{\circ} \mathrm{F}\right)$ simulated $\mathrm{PFBC}$ process gas environment that contained gas phase sulfur and alkali

80. Micrographs illustrating the morphology and thickness of the oxide formations that resulted along the outer surface of the Technetics Fecralloy fibers that were located near the i.d. or pulse cycled surface of the 496 hour, $840^{\circ} \mathrm{C}\left(1550^{\circ} \mathrm{F}\right)$, simulated PFBC-exposed, filter media.....

81. Higher magnification micrographs illustrating extensive oxidation of the Fecralloy fibers and embedded mesh that were present along the outer surface of the Technetics filtration media after 496 hours of operation in the $840^{\circ} \mathrm{C}\left(1550^{\circ} \mathrm{F}\right)$, gas phase sulfur and alkalicontaining, simulated PFBC process gas environment

82. Filter element array for demonstration of particulate removal capabilities and thermal stability of 1.5 and $2.0 \mathrm{~m}$ candle filter elements

83. Failure of the $2.0 \mathrm{~m} \mathrm{Bekaert/Mott} \mathrm{candle} \mathrm{filter} \mathrm{after} 81$ hours of high temperature, steady state, PFBC testing.

84. Wrinkled appearance of the Bekaert/Mott and Microfiltrex filtration media after completion of the simulated PFBC accelerated pulse cycle test campaign

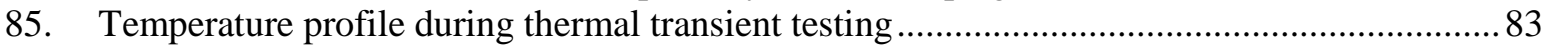

86. Filter elements at the conclusion of steady state, accelerated pulse cycling, and thermal transient testing 
87. Photograph illustrating the absence of ash along the i.d. or pulse cycled surface of the Pall FeAl, USF 316L, and Microfiltrex Fecralloy filter elements, but minor presence of ash along the i.d. or pulse cycled surface of the Bekaert/Mott Fecralloy filter element at the conclusion of the steady state, accelerated pulse cycle, and thermal transient test campaign .85

88. Scanning electron micrographs illustrating limited penetration of ash fines into the Bekaert/Mott and Microfiltrex Fecralloy filtration media. 


\section{EXECUTIVE SUMMARY}

As a key component in advanced coal or biomass-based power applications, hot gas filtration systems protect the downstream gas turbine components from particle fouling and erosion, cleaning the process gas to meet emission requirements. When installed in either pressurized fluidized-bed combustion (PFBC) or integrated gasification combined cycle (IGCC) plants, lower downstream component costs are projected, in addition to improved energy efficiency, lower maintenance, and elimination of additional and expensive fuel or flue gas treatment systems. As a critical component, long-term performance, durability and life of the porous filter elements are essential to the successful operation of hot gas filtration systems in advanced combustion and gasification applications.

Porous metal filter media as Hastelloy $\mathrm{X}$ were used to construct particulate filtration elements during the late 1970's. Accelerated oxidation or corrosion, and loss of tensile strength and load bearing capability of the porous metal filter media resulted. As proposed PFBC system operating temperatures were increased to $870^{\circ} \mathrm{C}\left(1600^{\circ} \mathrm{F}\right)$, efforts were refocused through the early 1990 's on the development of filter systems which utilized monolithic ceramic clay bonded silicon carbide candle filters. For operation in combustion gas environments, oxide-based, porous ceramic filter matrices were developed in order to achieve the chemical stability requirements for materials during long-term operation. Both oxide, as well as nonoxide porous ceramic filters were installed and operated in Siemens Westinghouse's Advanced Particulate Filtration systems at the American Electric Power PFBC Tidd Demonstration Plant in Brilliant, Ohio, and at the Foster Wheeler pressurized circulating fluidized-bed combustion (PCFBC) test facility in Karhula, Finland. Siemens Westinghouse conducted extensive filter material surveillance programs for candles that had been operated in each facility. Failure of the oxide-based candles was attributed to thermal failure of alumina/mullite matrix resulting during long-term pulse cycling of the elements, as well as to thermal shock of the matrix during plant thermal transient events. For the nonoxide-based clay bonded silicon carbide elements, elongation and failure of the candles resulted which lead to improvements and stabilization of the clay binder, while oxidation of the silicon carbide grains and volume expansion of the component were addressed through the inclusion of oxidation resistant grain and/or binder additives.

To provide a more 'ruggidized' filter system, emphasis in the mid-1990's was focused on the development and manufacture of advanced nonoxide- and oxide-based, porous second-generation, continuous fiber ceramic composite and filament wound filter elements which were projected to have significantly improved fracture toughness characteristics over that of the first-generation monolithic ceramic filter materials. When tested in Siemens Westinghouse filter systems, oxidation of the nonoxide-based elements lead to brittle failure of the candles, while debonding of external particulate filtration membranes, and failure initially occurred along seams and non-integral flanges and end caps of the advanced second-generation oxide-based candle filters.

Towards the end of the 1990's, advanced corrosion resistant porous metal and intermetallic filter media were considered as a potential low risk alternative for use in PFBC hot gas filtration systems, particularly when installed in second-generation PCFBC systems operating at temperatures of $650-750^{\circ} \mathrm{C}\left(1200-1400^{\circ} \mathrm{F}\right)$. Porous advanced metal and intermetallic filters were expected to be non-brittle (i.e., ductile), and exhibit improved thermal stress damage tolerance in comparison to ceramic filter elements. Advantages over ceramic candles also included eliminating the need for thermal regenerators, the ability to directly weld metal filters to support structures to form hermetic seals, eliminating the use of ceramic fiber dust seals, and the ability to form metals in a wide variety 
of shapes. These advantages would permit more robust designs to be considered, improve packaging, lower system costs, and increase process operating reliability.

In September 1998, Siemens Westinghouse Power Corporation (SWPC) initiated effort on the Metal Filters for Pressurized Fluid Bed Combustion Applications program to develop and evaluate the use of porous, high temperature, sinter bonded fiber and powder metal media candle filters in PFBC and PCFBC systems. Advanced alloys selected for evaluation in this program included Haynes 230, Haynes 214, Haynes 188, Haynes 556, iron aluminide (FeAl), and Fecralloy (FeCrAl(Y)) porous metal media manufactured by U.S Filter/Fluid Dynamics (USF), Pall Advanced Separation Systems, Mott Corporation, Fairey Microfiltrex, and Technetics. Elements constructed from 310S, Inconel 600, and Hastelloy X were included as commercially available materials for comparison with the performance and stability of the advanced alloys and intermetallic media in this program.

Testing of composite candle filters constructed from joined metal media filter sections was conducted in Siemens Westinghouse's bench-scale PFBC particulate filtration system in Pittsburgh, PA. Composite candle filter elements were installed and operated in a $650^{\circ} \mathrm{C}\left(1200^{\circ} \mathrm{F}\right), 760^{\circ} \mathrm{C}$ $\left(1400^{\circ} \mathrm{F}\right)$, and $840^{\circ} \mathrm{C}\left(1550^{\circ} \mathrm{F}\right)$, pressurized $(1.103 \mathrm{kPa}(147 \mathrm{psi}))$, simulated PFBC process gas environment containing $6 \% \mathrm{O}_{2}, 7 \% \mathrm{CO}_{2}, 73 \% \mathrm{~N}_{2}, 14 \% \mathrm{H}_{2} \mathrm{O}$, and $200 \mathrm{ppm}(\max ) \mathrm{SO}_{2}$, for periods of 250, 500, and 1000 hours. Post-test characterization of each commercially available, advanced alloy metal media, and intermetallic filter media included determination of the residual process temperature strength, and an assessment of the microstructural and/or phase stability of the porous filter matrix. Testing was similarly conducted at $840^{\circ} \mathrm{C}\left(1550^{\circ} \mathrm{F}\right)$ in the absence of gas phase sulfur, and with the addition of 1 ppm gas phase alkali in the sulfur-laden simulated PFBC process gas environment.

Based on testing conducted in this program, porous sinter bonded $\mathrm{FeAl}$ and Fecralloy media are identified as candidate materials for construction of metal filter elements for installation and potential extended operation in high temperature, gas phase alkali-free, PFBC/PCFBC applications. In the presence of $1 \mathrm{ppmv}$ gas phase alkali, accelerated oxidation, pore closure, crack formations through the surface oxide, and/or removal of filter media sections limit the use of all porous sinter bonded metal media filter elements during operation in an $840^{\circ} \mathrm{C}\left(1550^{\circ} \mathrm{F}\right) \mathrm{PFBC} / \mathrm{PCFBC}$ process gas environment. 


\subsection{INTRODUCTION}

\subsection{Program Overview and Filter Element Construction}

In September 1998, Siemens Westinghouse Power Corporation (SWPC) ${ }^{1}$ initiated effort on the Metal Filters for Pressurized Fluid Bed Combustion (PFBC) Applications program ${ }^{2}$ to develop and evaluate the use of porous, high temperature, metal media candle filters in PFBC and pressurized circulating fluidized bed combustion (PCFBC) systems. In conjunction with U.S. Filter/Fluid Dynamics (USF), ${ }^{3}$ Pall Advanced Separation Systems, Mott Corporation, Fairey Microfiltrex, ${ }^{4}$ Technetics, and Ultramet, SWPC produced composite metal media filter elements (Figure 1) for exposure to simulated PFBC conditions in the SWPC Science and Technology Center (STC) test facilities in Pittsburgh, PA.

Advanced alloys selected for evaluation in this program included Haynes 230, Haynes 214, Haynes 188, Haynes 556, iron aluminide (FeAl), and Fecralloy $(\mathrm{FeCrAl}(\mathrm{Y}))$ porous metal media (Table 1). Elements constructed from 310 S, Inconel 600, and Hastelloy X were included as commercially available materials for comparison in this program. Metal filter elements manufactured by USF consisted of $\sim 25 \mu \mathrm{m}$ diameter metal media fibers that were sinter bonded at high temperature, forming a $\leq 1 \mathrm{~mm}$ thick filtration mat layer (Table 2, Figure 2). The filtration media was subsequently inter-layered with wire mesh screens for structural support, wrapped around a perforated, densified metal tube, and longitudinally seam welded. Joiner end rings of $310 \mathrm{~S}$ were welded to both ends of the $\sim 20.3 \mathrm{~cm}$ long cylindrical USF filter media sections for assembly of multiple units into an $\sim 1.5 \mathrm{~m}$ composite candle filter. Densified end caps and SWPC's fail-safe/regenerator-contained flanges were welded to the ends of the $1.5 \mathrm{~m}$ long cylindrical filter body [1].

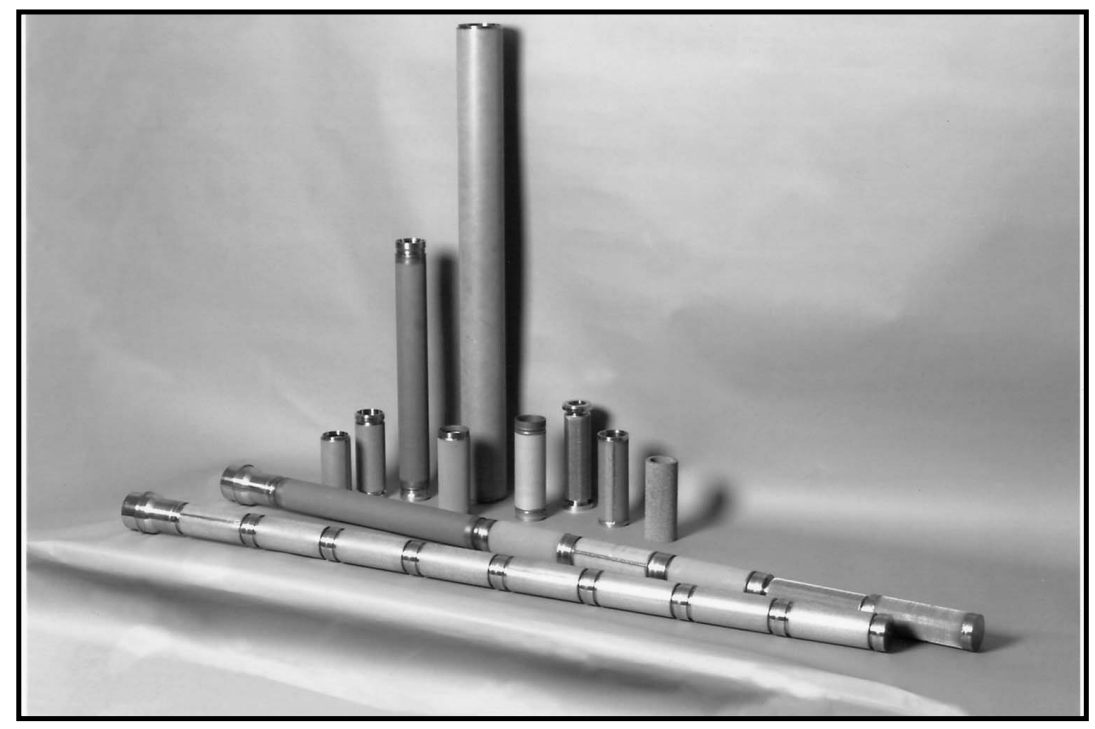

Figure 1 - Metal filters for PFBC and PCFBC applications.

\footnotetext{
${ }^{1}$ Formerly Westinghouse Electric Corporation.

${ }^{2}$ DOE/NETL Contract No. DE-AC26-98FT40002.

${ }^{3}$ Currently Pall Corporation.

${ }^{4}$ Currently Microfiltrex, a member of the Porvair Filtration Group.
} 


\begin{tabular}{|c|c|c|c|c|c|c|}
\hline \multicolumn{7}{|c|}{$\begin{array}{l}\text { TABLE } 1 \\
\text { DEVELOPMENTAL AND COMMERCIALLY AVAILABLE METAL FILTER MEDIA }\end{array}$} \\
\hline Supplier & $\begin{array}{l}\text { U.S. Filter/ } \\
\text { Dynamics }\end{array}$ & $\begin{array}{l}\text { Pall } \\
\text { Advanced } \\
\text { Separation } \\
\text { Systems }\end{array}$ & $\begin{array}{c}\text { Mott } \\
\text { Corporation }\end{array}$ & $\begin{array}{c}\text { Fairey } \\
\text { Microfiltrex }\end{array}$ & Technetics & Ultramet \\
\hline Media Architecture & Fibers & Powder & Powder & Fibers & Fibers & $\begin{array}{c}\text { Reticulated } \\
\text { Foam (b) }\end{array}$ \\
\hline $310 S$ & $\mathrm{X}$ & $\mathrm{X}$ & & & & \\
\hline Inconel 600 & $\mathrm{X}$ & & $\mathrm{X}$ & & & \\
\hline Hastelloy X & $\mathrm{X}$ & $\mathrm{X}$ & & & & \\
\hline Haynes 214 & $\mathrm{X}$ & & & & & \\
\hline Haynes 556 & $\mathrm{X}$ & & & & & \\
\hline FeAl (Mod) & $\mathrm{X}$ & $\mathrm{X}(\mathrm{a})$ & & & & \\
\hline Fecralloy & $\mathrm{X}$ & & & $\mathrm{X}$ & $\mathrm{X}$ & \\
\hline Haynes 188 & $\mathrm{X}$ & & & & & \\
\hline Haynes 230 & $\mathrm{X}$ & & & & & \\
\hline $\mathrm{Ni}$ & & & & & & $\mathrm{X}$ \\
\hline
\end{tabular}

(a) $2 \% \mathrm{Cr}$.

(b) Sections were not included within the composite candle filter architecture, but exposed to simulated PFBC process gas at temperature in a flow-over fashion.

Similarly, the architecture of the Fairey Microfiltrex filter element sections consisted of a longitudinally seam welded, porous, fibrous, filtration mat and an external wire mesh support layer that were welded to an underlying perforated cylindrical metal structural support. In contrast, the Technetics filter element sections consisted of a porous, fibrous, metal filtration layer, and an external wire mesh support overlayer. Joiner end rings of $310 \mathrm{~S}$ were welded to the Fairey Microfiltrex and Technetics filter element sections.

The Pall and Mott filter element sections consisted of $\sim 25 \mu \mathrm{m}$ metal particles (i.e., powder) that were sinter bonded into an $\sim 2 \mathrm{~mm}$ and $\sim 4 \mathrm{~mm}$ thick porous filter wall, respectively. In contrast to the seamless monolithic Pall 310S and Mott Inconel 600 filter media sections, the Pall Hastelloy X filter section contained a longitudinal seam weld. Joiner end rings of $310 \mathrm{~S}$ were added to the cylindrical Pall and Mott filter sections, prior to assembly with the Fairey Microfiltrex and Technetics filter sections, forming an $\sim 1.5 \mathrm{~m}$ composite candle. Fail-safe/regenerator-contained flanges and end caps were welded to the body of each composite candle filter.

\subsection{Program Objectives}

The objectives of this program were to evaluate the potential use of porous metal media for hot gas filter applications in PFBC systems. Siemens Westinghouse has worked with key industry metal media suppliers to develop suitable, corrosion-resistant materials representing both the metal powder, fiber, and wire laminate technologies. The application of metal media to PFBC systems requires materials to be capable of withstanding operating temperatures of $650^{\circ} \mathrm{C}$ to $900^{\circ} \mathrm{C}\left(1200^{\circ} \mathrm{F}\right.$ to $\left.1650^{\circ} \mathrm{F}\right)$ in coal combustion process streams that potentially contain gas phase sulfur and alkali. 


\begin{tabular}{|c|c|c|c|c|c|c|c|}
\hline & - COMPO & JENT ARCH & $\begin{array}{l}\text { TABI } \\
\text { METAL FILTE } \\
\text { TECTURE AND }\end{array}$ & $\begin{array}{l}\text { 2 } 2 \\
\text { ELEMEN' } \\
\text { MATERIA }\end{array}$ & S OF CONST & RUCTION - & \\
\hline Supplier & $\begin{array}{l}\text { Metal } \\
\text { Media }\end{array}$ & $\begin{array}{c}\text { Media } \\
\text { Architecture }\end{array}$ & $\begin{array}{l}\text { Outer } \\
\text { Wire } \\
\text { Mesh }\end{array}$ & $\begin{array}{c}\text { Internal } \\
\text { Structural } \\
\text { Core }\end{array}$ & $\begin{array}{l}\text { Longitudinal } \\
\text { Weld }\end{array}$ & $\begin{array}{c}\text { Weld } \\
\text { Material }\end{array}$ & End Rings \\
\hline \multirow[t]{9}{*}{ U.S. Filter } & $310 \mathrm{~S}$ & Fiber & $\begin{array}{l}\text { Hast X/Hast } X \\
\text { (a) }\end{array}$ & $310 \mathrm{~S}$ & Included & 556 Wire & $310 \mathrm{~S} / 310 \mathrm{~S} * *$ \\
\hline & Inconel 600 & Fiber & $\begin{array}{l}\text { Hast X/Hast } X \\
\text { (a) }\end{array}$ & $310 \mathrm{~S}$ & Included & 556 Wire & $310 \mathrm{~S} / 310 \mathrm{~S} * *$ \\
\hline & $\begin{array}{c}\text { Hastelloy } \\
\text { X }\end{array}$ & Fiber & $\begin{array}{l}\text { Hast } X / \text { Hast } X \\
\text { (a) }\end{array}$ & $310 \mathrm{~S}$ & Included & 556 Wire & $310 \mathrm{~S} / 310 \mathrm{~S} * *$ \\
\hline & Haynes 214 & Fiber & $\begin{array}{l}\text { Fecralloy/ } \\
\text { Fecralloy or } \\
\text { Hast X or } \\
\text { Inconel (a) } \\
\end{array}$ & $310 \mathrm{~S}$ & Included & $\begin{array}{l}556 \text { Wire or } \\
\text { Inconel }\end{array}$ & $310 \mathrm{~S} / 310 \mathrm{~S} * *$ \\
\hline & Haynes 556 & Fiber & $\begin{array}{l}\text { Hast X/Hast X } \\
\text { (a) }\end{array}$ & $310 \mathrm{~S}$ & Included & 556 Wire & $310 \mathrm{~S} / 310 \mathrm{~S} * *$ \\
\hline & $\begin{array}{c}\mathrm{FeAl} \\
(\mathrm{Mod})\end{array}$ & Fiber & $\begin{array}{l}\text { Hast X/Hast X } \\
\text { (a) }\end{array}$ & $310 \mathrm{~S}$ & Included & $\begin{array}{c}\text { TBD } \\
\text { (Kanthal) }\end{array}$ & $310 \mathrm{~S} / 310 \mathrm{~S} * *$ \\
\hline & Fecralloy & Fiber & $\begin{array}{c}\text { Fecralloy/ } \\
\text { Fecralloy or } \\
\text { Hast X (a) }\end{array}$ & $310 \mathrm{~S}$ & Included & $\begin{array}{c}\text { Kanthal or } \\
556 \text { Wire or } \\
\text { Hastelloy }\end{array}$ & $310 \mathrm{~S} / 310 \mathrm{~S}^{* *}$ \\
\hline & Haynes 188 & Fiber & $\begin{array}{l}\text { Hast X/Hast X } \\
\text { (a) }\end{array}$ & $310 \mathrm{~S}$ & Included & 556 & $310 \mathrm{~S} / 310 \mathrm{~S} * *$ \\
\hline & Haynes 230 & Fiber & $\begin{array}{l}\text { Hast X/Hast X } \\
\text { (a) }\end{array}$ & $310 \mathrm{~S}$ & Included & 556 & $310 \mathrm{~S} / 310 \mathrm{~S}^{* *}$ \\
\hline \multirow[t]{3}{*}{ Pall } & $310 \mathrm{~S}$ & Powder & None & None & None & $309 / 310 \mathrm{~S}$ & $310 \mathrm{~S} / 310 \mathrm{~S} * *$ \\
\hline & $\begin{array}{c}\text { Hastelloy } \\
\text { X }\end{array}$ & Powder & None & None & Included & $\begin{array}{l}\text { Hastelloy } \\
\text { C276 }\end{array}$ & $\begin{array}{c}\text { 310S/ } \\
\text { Hastelloy } \\
\text { C276** }\end{array}$ \\
\hline & $\begin{array}{c}\text { Iron } \\
\text { Aluminide }\end{array}$ & Powder & None & None & None & $309 / 310 \mathrm{~S}$ & $310 \mathrm{~S} / 310 \mathrm{~S}^{* *}$ \\
\hline Mott & Inconel 600 & Powder & None & None & None & Inconel 82 & $310 \mathrm{~S}$ \\
\hline $\begin{array}{c}\text { Fairey } \\
\text { Microfiltrex }\end{array}$ & $\begin{array}{l}\text { CCTFTM } \\
\text { Fecralloy }\end{array}$ & Fiber & Hastelloy C276 & $\begin{array}{c}\text { Hastelloy } \\
\text { C276 } \\
316 \mathrm{~L} \\
\text { Support } \\
\text { Core } \\
\end{array}$ & Included & $\begin{array}{c}\text { Autogeneous } \\
* * *\end{array}$ & $310 \mathrm{~S}$ \\
\hline Technetics & Fecralloy* & Fiber & & & Included & Hastelloy X & $310 \mathrm{~S}$ \\
\hline Ultramet & $\mathrm{Ni}$ & $\begin{array}{l}\text { Reticulated } \\
\text { Foam }\end{array}$ & None & None & None & None & None \\
\hline
\end{tabular}

(a) Mesh embedded within filtration mat/Mesh layered between filtration mat and structural support core.

* $\mathrm{Fe}(22.5 \% \mathrm{Cr}, 5 \% \mathrm{Al}, 0.5 \% \mathrm{Y})$

** Transition ring section added to join porous filter media to SWPC provided end rings.

*** Weld pool generated from parent metal.

As shown in Table 3, five test campaigns were conducted at SWPC STC for periods up to $\sim 1,000$ hours in duration, exposing six, $1.5 \mathrm{~m}$, composite metal media candle filters to temperatures of $650^{\circ} \mathrm{C}\left(1200^{\circ} \mathrm{F}\right), 760^{\circ} \mathrm{C}\left(1400^{\circ} \mathrm{F}\right)$, and $840^{\circ} \mathrm{C}\left(1550^{\circ} \mathrm{F}\right)$, and system pressures of $1,013 \mathrm{kPa}$ 


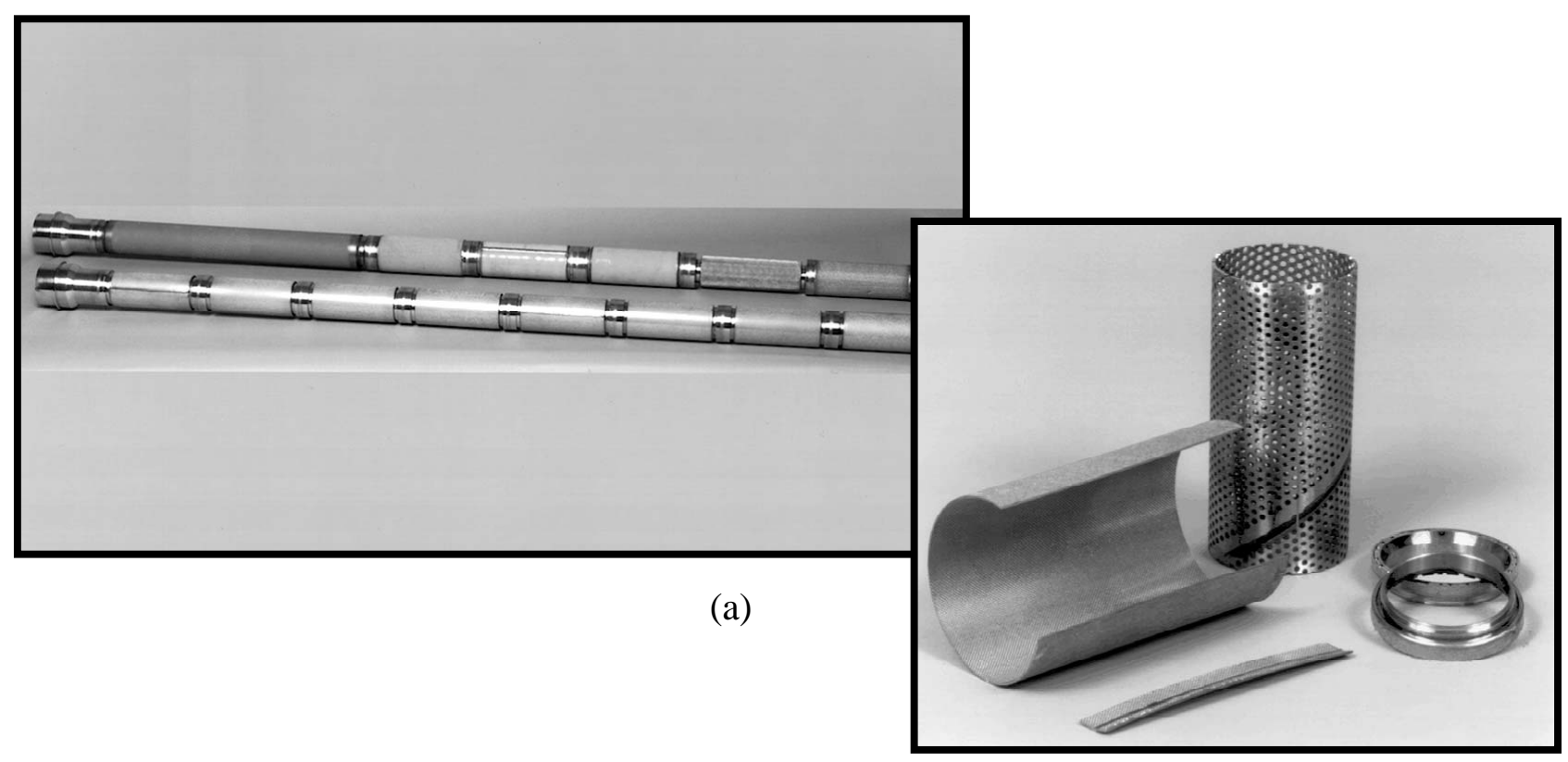

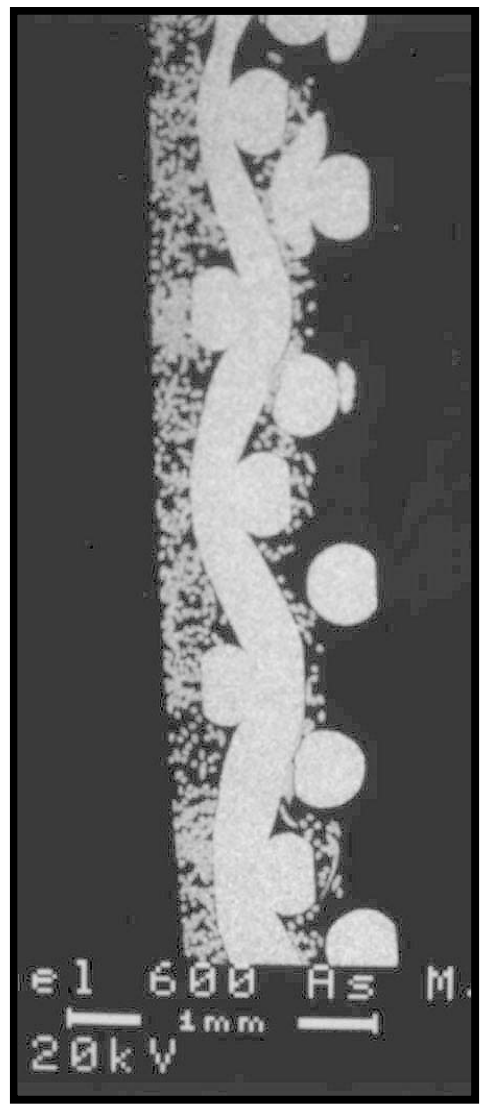

(b)
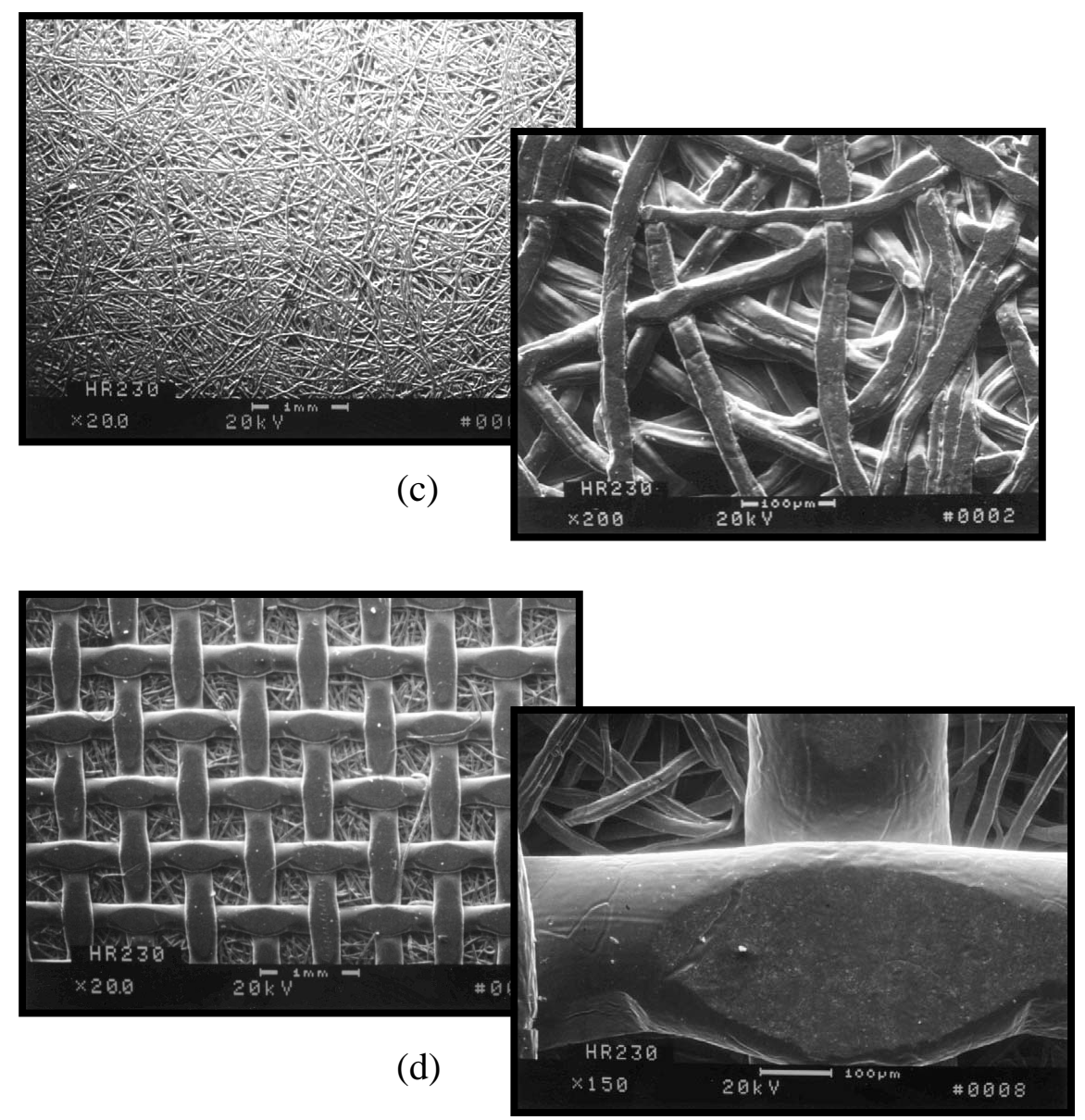

Figure 2 - Porous, sinter bonded, fibrous, USF filter metal media. (a) Composite architecture; (b) Cross-sectioned filtration media wall; (c) External filtration surface; (d) Internal structural mesh surface. 


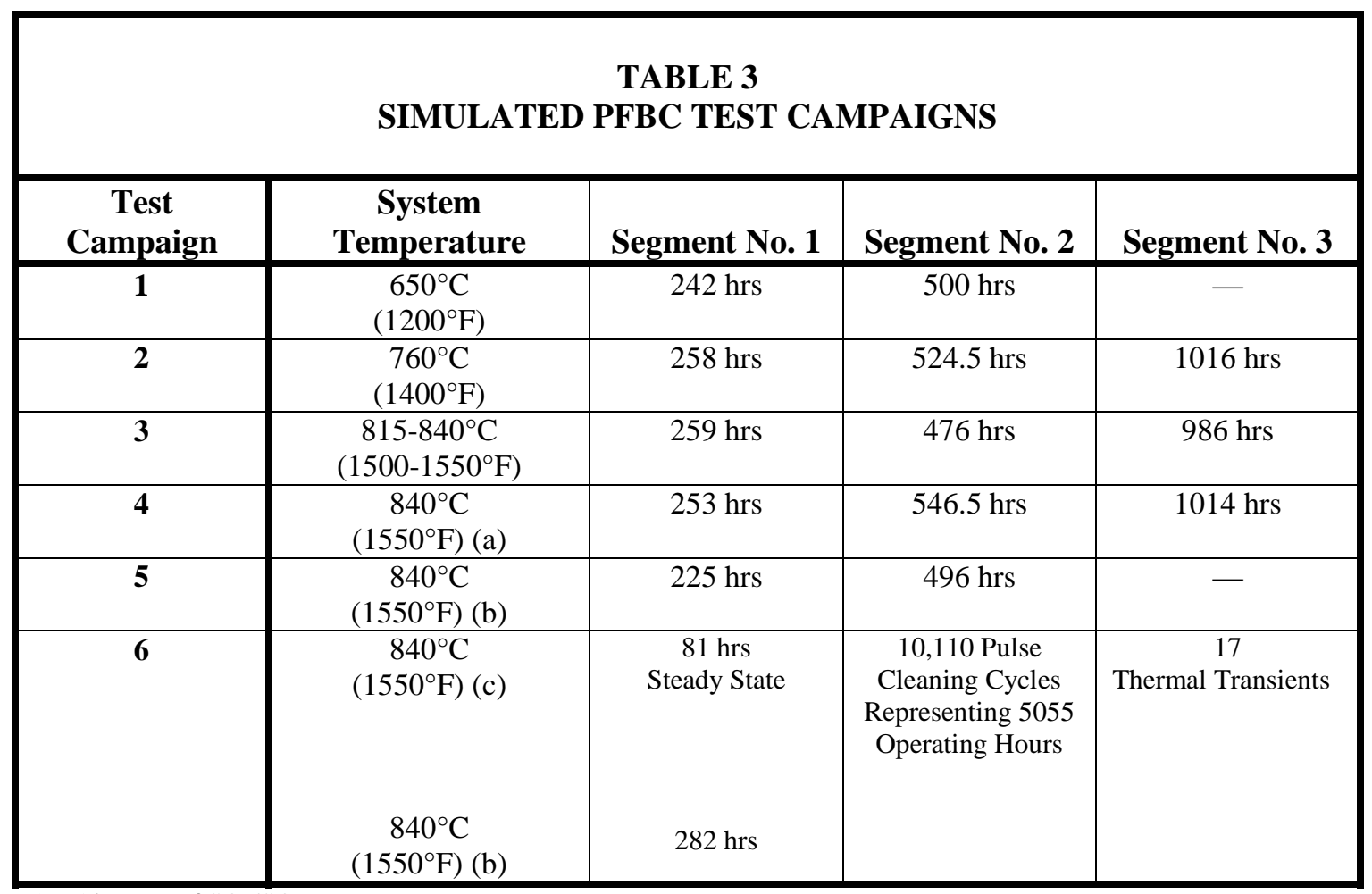

(a) Absence of $\mathrm{SO}_{2} / \mathrm{SO}_{3}$.

(b) Inclusion of $\mathrm{SO}_{2} / \mathrm{SO}_{3}$ and gas phase alkali.

(c) Particulate filtration and life testing.

(147 psia), under simulated PFBC process gas conditions containing $200 \mathrm{ppmv} \mathrm{SO}_{2} / \mathrm{SO}_{3}$ (Figure 3). Gas phase alkali was included in the $840^{\circ} \mathrm{C}\left(1550^{\circ} \mathrm{F}\right)$ simulated $\mathrm{PFBC}$ process gas environment in Test Campaign No. 5, at concentrations of 1 ppmv. Pre- and post-test characterization of the component, metal media, and welds included visual inspection, room temperature gas flow resistance measurements, microstructural analyses, and high temperature tensile strength testing. A final test campaign series was conducted in which $1.5 \mathrm{~m}$ and $2.0 \mathrm{~m}$ metal media candle filters were subjected to $840^{\circ} \mathrm{C}\left(1550^{\circ} \mathrm{F}\right)$ steady state particulate filtration, accelerated pulse cycling, and thermal transient testing. Fecralloy elements manufactured by Mott ${ }^{5}$ were included in Test Campaign No. 6. In a parallel effort at SWPC STC, $1.5 \mathrm{~m}$ Mott elements were exposed to the $840^{\circ} \mathrm{C}\left(1550^{\circ} \mathrm{F}\right)$ simulated $\mathrm{PFBC}$ process gas containing gas phase alkali and sulfur.

\footnotetext{
${ }^{5}$ Formerly Bekaert Fibre Technology.
} 


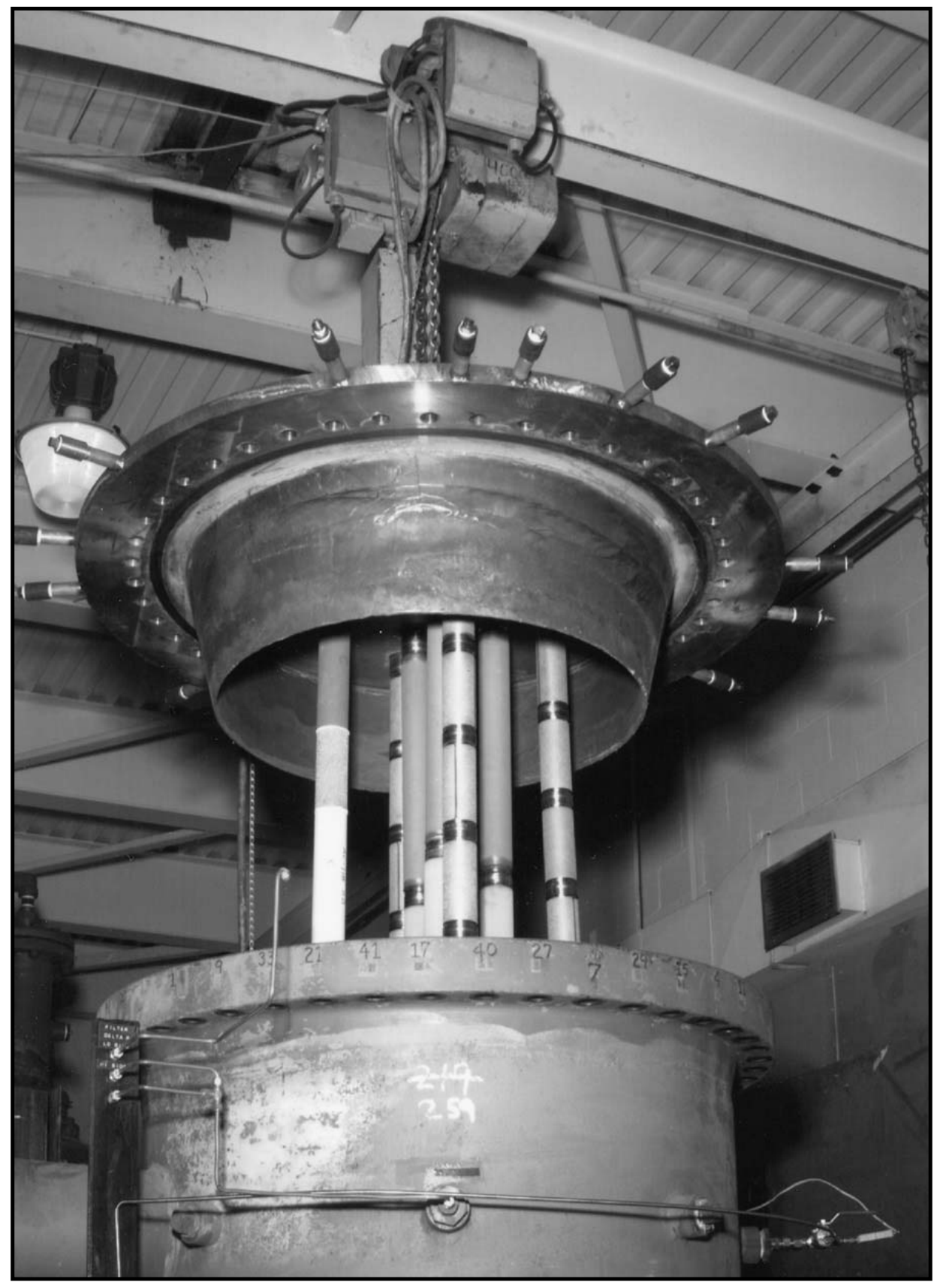

Figure 3 - Composite metal filter array used in SWPC STC PFBC simulator testing. 


\subsection{COMPONENT AND MATERIALS EVALUATION}

\subsection{Room Temperature Gas Flow Resistance Measurements}

As shown in Figure 4, the as-manufactured, room temperature, gas flow resistance through the sinter bonded fibrous, USF, Fairey Microfiltrex, and Technetics metal media filter element sections was $\leq 2$ in-wg at $10 \mathrm{ft} / \mathrm{min}^{6}{ }^{6}$ In contrast, the as-manufactured, room temperature, gas flow resistance through the sinter bonded metal powder, Pall and Mott filter media ranged from 4 to $10 \mathrm{in}-\mathrm{wg}$ at $10 \mathrm{ft} / \mathrm{min}$. In terms of component architecture and relative gas flow resistance, the porous sinter bonded metal powder media is analogous to the thicker walled, oxide or nonoxide-based, monolithic, ceramic filter materials (i.e., Coors P-100A-1 alumina/mullite; Schumacher FT20; Pall 326; Blasch and Ensto mullite bonded alumina; etc.), while the porous sinter bonded fibrous metal media is analogous to the thinner walled, continuous fiber ceramic composites (CFCC; 3M oxide/nonoxide, McDermott, and Techniweave CFCCs), and filament wound porous ceramic filter matrix (DuPont ${ }^{7}$ PRD-66).

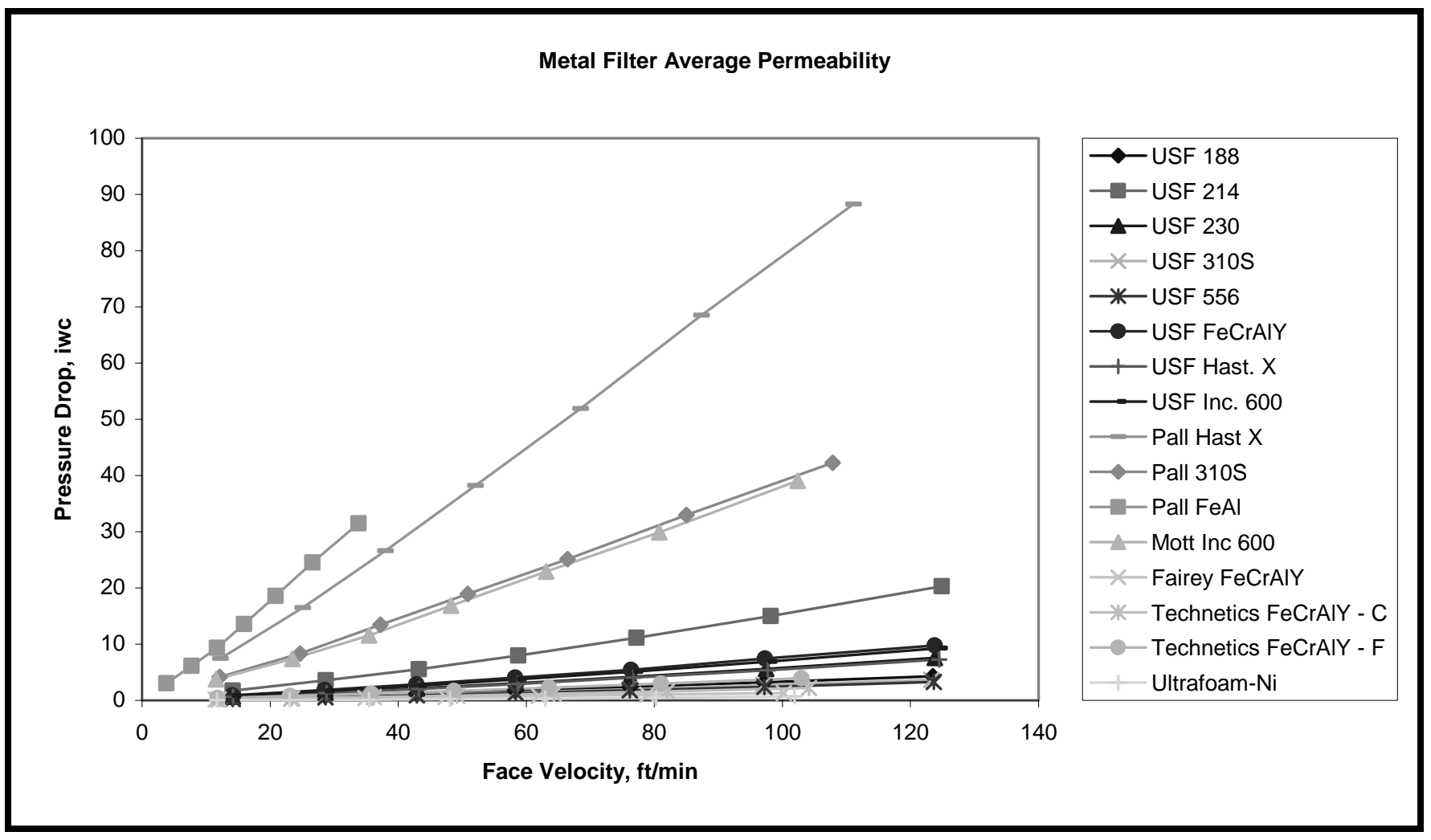

Figure 4 - Room temperature gas flow resistance measurements of as-manufactured, porous, metal filter media.

\footnotetext{
${ }^{6}$ SWPC specifications: $\leq 10 \mathrm{in}-\mathrm{wg}$ at $10 \mathrm{ft} / \mathrm{min}$.

${ }^{7}$ Currently GE Power Systems.
} 


\subsection{Metal Filter Media and Component Integrity}

Table 4 identifies the order of the filter element sections within the six composite candle filters that were used in this test program. After completion of 500 hours of $650^{\circ} \mathrm{C}\left(1200^{\circ} \mathrm{F}\right)$ simulated PFBC testing, all filter element sections remained intact (Table 5). As temperature was increased to $760^{\circ} \mathrm{C}$ $\left(1400^{\circ} \mathrm{F}\right)$, circumferential failure of the Pall $310 \mathrm{~S}$ filter element sections resulted along the metal joiner ring welds (Figure 5). When removed from the ash hopper, the brittle fractured surface of the powder metal media was observed.

At temperatures $>650^{\circ} \mathrm{C}\left(>1200^{\circ} \mathrm{F}\right)$, debonding and removal of sections of the USF Haynes 556 media resulted, reducing the expected particulate collection efficiency of the porous filtration media. Similar failure of the Pall $310 \mathrm{~S}$ and USF Haynes 556 media occurred at temperatures of $815-840^{\circ} \mathrm{C}$ $\left(1500-1550^{\circ} \mathrm{F}\right)$.

In the presence of gas phase sulfur and alkali at $840^{\circ} \mathrm{C}\left(1550^{\circ} \mathrm{F}\right)$, densification of the outer surface of the USF Fecralloy, Haynes 230, 310S, and Inconel 600 filtration media resulted. In addition, failure of the Pall FeAl and 310S matrices, the USF Haynes 214, Haynes 188, Haynes 556, and Hastelloy X matrices, and Fairey Microfiltrex Fecralloy matrix occurred. Circumferential cracks near the metal joiner ring of the Mott Inconel 600 filter section were observed, and the integrity of the Technetics' longitudinal seam weld was questioned.

\begin{tabular}{|c|c|}
\hline \multicolumn{2}{|c|}{ TABLE 4 } \\
COMPOSITE METAL FILTER ELEMENTS \\
\hline Flange & Flange \\
\hline USF 214 & Pall FeAl \\
USF 230 & Mott Inconel 600 \\
USF 556 & Pall Hast X-1309H \\
USF 188 & Pall 310S-329S100-11 \\
USF Fecralloy & Fairey CCTFTM \\
USF IN600 & Technetics Fecralloy \\
USF Hast X & \\
USF 310S & End Cap \\
\hline End Cap &
\end{tabular}

\subsection{Mechanical Properties — Process Temperature Tensile Strength}

With the exception of the Pall FeAl filter element sections, the length of all metal filter media sections was $13.5 \mathrm{~cm}(\sim 5-5 / 16$ in). The FeAl filter elements sections used in this program were Pall's standard $44.5 \mathrm{~cm}$ (15.5 in) length materials. After removal of the heat affect zone adjacent to the welds along the metal joiner rings, and longitudinal sectioning removing weld seams, if present, both the as-manufactured and simulated PFBC-exposed filter media (Test Campaign No. 1 through No. 6) were prepared for tensile strength testing. Standard tensile bars ${ }^{8}$

\footnotetext{
${ }^{8}$ Overall dimensions: $12.4 \mathrm{~cm}$ (4.88 in) long x $0.64 \mathrm{~cm}$ (0.25 in) wide; Gauge section: $3.8 \mathrm{~cm}$ (1.5 in) long x $1.27 \mathrm{~cm}$ (0.5 in) wide.
} 


\begin{tabular}{|c|c|c|c|c|c|}
\hline \multirow[b]{3}{*}{$\begin{array}{l}\text { Filter } \\
\text { Media }\end{array}$} & \multicolumn{5}{|c|}{$\begin{array}{c}\text { TABLE } 5 \\
\text { METAL FILTER MEDIA AND COMPONENT PHYSICAL INTEGRITY }\end{array}$} \\
\hline & \multicolumn{5}{|c|}{ Simulated PFBC Operating Conditions } \\
\hline & $650^{\circ} \mathrm{C}\left(1200^{\circ} \mathrm{F}\right)$ & $7^{\circ} 0^{\circ} \mathrm{C}\left(1400^{\circ} \mathrm{F}\right)$ & $\begin{array}{c}815-840 \circ \mathrm{C} \\
(1500-1550 \\
\end{array}$ & $\begin{array}{l}840^{\circ} \mathrm{C}\left(1550^{\circ} \mathrm{F}\right) \\
-\mathrm{No} \mathrm{SO}_{2}-\end{array}$ & $\begin{array}{l}840^{\circ} \mathrm{C}\left(1550^{\circ} \mathrm{F}\right) \\
-\mathrm{SO}_{2} \& \mathrm{Na}-\end{array}$ \\
\hline Pall FeAl & Intact & Intact & Intact & Intact & $\begin{array}{c}\text { Failure at weld; Volume } \\
\text { expansion; Raised Bubbles; } \\
\text { Longitudinal and } \\
\text { circumferential distortion } \\
\text { within } 225 \mathrm{hrs}\end{array}$ \\
\hline USF Fecralloy & $\begin{array}{c}\text { Transverse linear } \\
\text { indications and } \\
\text { through-cracks along } \\
\text { longitudinal weld } \\
\text { seam after } 242 \mathrm{hr} ; \\
\text { Section removed and } \\
\text { media was modified } \\
\end{array}$ & Intact & Intact & Intact & $\begin{array}{l}\text { Intact; Densified external } \\
\text { surface (496 hrs) }\end{array}$ \\
\hline USF Haynes 230 & Intact & Intact & Intact & Intact & $\begin{array}{c}\text { Intact; Densified external } \\
\text { surface (496 hrs) }\end{array}$ \\
\hline USF Haynes 214 & Intact & Intact & Intact & Intact & $\begin{array}{l}\text { Removal of the filtration } \\
\text { media and outer mesh within } \\
496 \text { hrs }\end{array}$ \\
\hline USF Haynes 188 & Intact & Intact & Intact & Intact & $\begin{array}{l}\text { Expansion and separation of } \\
\text { filtration media radiating } \\
\text { from the circumferentially } \\
\text { welded metal joiner rings } \\
\text { within } 496 \mathrm{hrs} \text { (i.e., elephant } \\
\text { foot formation); Longitudinal } \\
\text { cracks within filter media }\end{array}$ \\
\hline USF Haynes 556 & Intact & $\begin{array}{c}\text { Isolated removal of } \\
\text { the outer filtration } \\
\text { mat occurred within } \\
1,016 \mathrm{hrs}\end{array}$ & $\begin{array}{l}\text { Isolated removal of } \\
\text { the outer filtration } \\
\text { mat occurred within } \\
259 \mathrm{hrs}\end{array}$ & $\begin{array}{l}\text { Isolated removal of } \\
\text { the outer filtration } \\
\text { mat occurred within } \\
253 \mathrm{hrs}\end{array}$ & $\begin{array}{l}\text { Expansion and separation of } \\
\text { filtration media radiating } \\
\text { from the circumferentially } \\
\text { welded metal joiner rings } \\
\text { within } 496 \text { hrs (i.e., elephant } \\
\text { foot formation); Longitudinal } \\
\text { cracks within filter media }\end{array}$ \\
\hline USF 310S & Intact & Intact & Intact & Intact & $\begin{array}{l}\text { Intact; Densified external } \\
\text { surface }(496 \mathrm{hrs})\end{array}$ \\
\hline USF Inconel 600 & Intact & Intact & Intact & Intact & $\begin{array}{c}\text { Intact; Densified external } \\
\text { surface (496 hrs) }\end{array}$ \\
\hline USF Hastelloy X & Intact & Intact & Intact & Intact & $\begin{array}{l}\text { Expansion and separation of } \\
\text { filtration media radiating } \\
\text { from the circumferentially } \\
\text { welded metal joiner rings } \\
\text { within } 496 \text { hrs (i.e., elephant } \\
\text { foot formation); Longitudinal } \\
\text { cracks within filter media; } \\
\text { Embrittlement and cracking } \\
\text { of the filtration media }\end{array}$ \\
\hline Pall 310S & Intact & $\begin{array}{l}\text { Circumferential } \\
\text { failure at metal ring } \\
\text { weld within } 258 \mathrm{hrs}\end{array}$ & $\begin{array}{l}\text { Circumferential } \\
\text { failure at metal ring } \\
\text { weld within } 259 \text { hrs }\end{array}$ & $\begin{array}{l}\text { Circumferential } \\
\text { failure at metal ring } \\
\text { weld within } 253 \mathrm{hrs}\end{array}$ & $\begin{array}{l}\text { Circumferential failure at } \\
\text { metal ring weld within } \\
225 \text { hrs }\end{array}$ \\
\hline Pall Hastelloy X & Intact & Intact & Intact & Intact & Surface scaling (496 hrs) \\
\hline Mott Inconel 600 & Intact & Intact & Intact & Intact & $\begin{array}{l}\text { Crack detected near } \\
\text { circumferential weld to ring } \\
\text { with } 225 \text { hrs }\end{array}$ \\
\hline $\begin{array}{c}\text { Fairey } \\
\text { Microfiltrex } \\
\text { Fecralloy }\end{array}$ & Intact & Intact & Intact & Intact & $\begin{array}{c}\text { Failure of the external Hast } \\
\text { C276 mesh; Localized } \\
\text { removal of filtration mat } \\
\text { within } 225 \text { hrs }\end{array}$ \\
\hline $\begin{array}{l}\text { Technetics } \\
\text { Fecralloy }\end{array}$ & Intact & Intact & Intact & Intact & $\begin{array}{l}\text { Continuity of the longitudinal } \\
\text { weld in question (496 hrs) }\end{array}$ \\
\hline
\end{tabular}



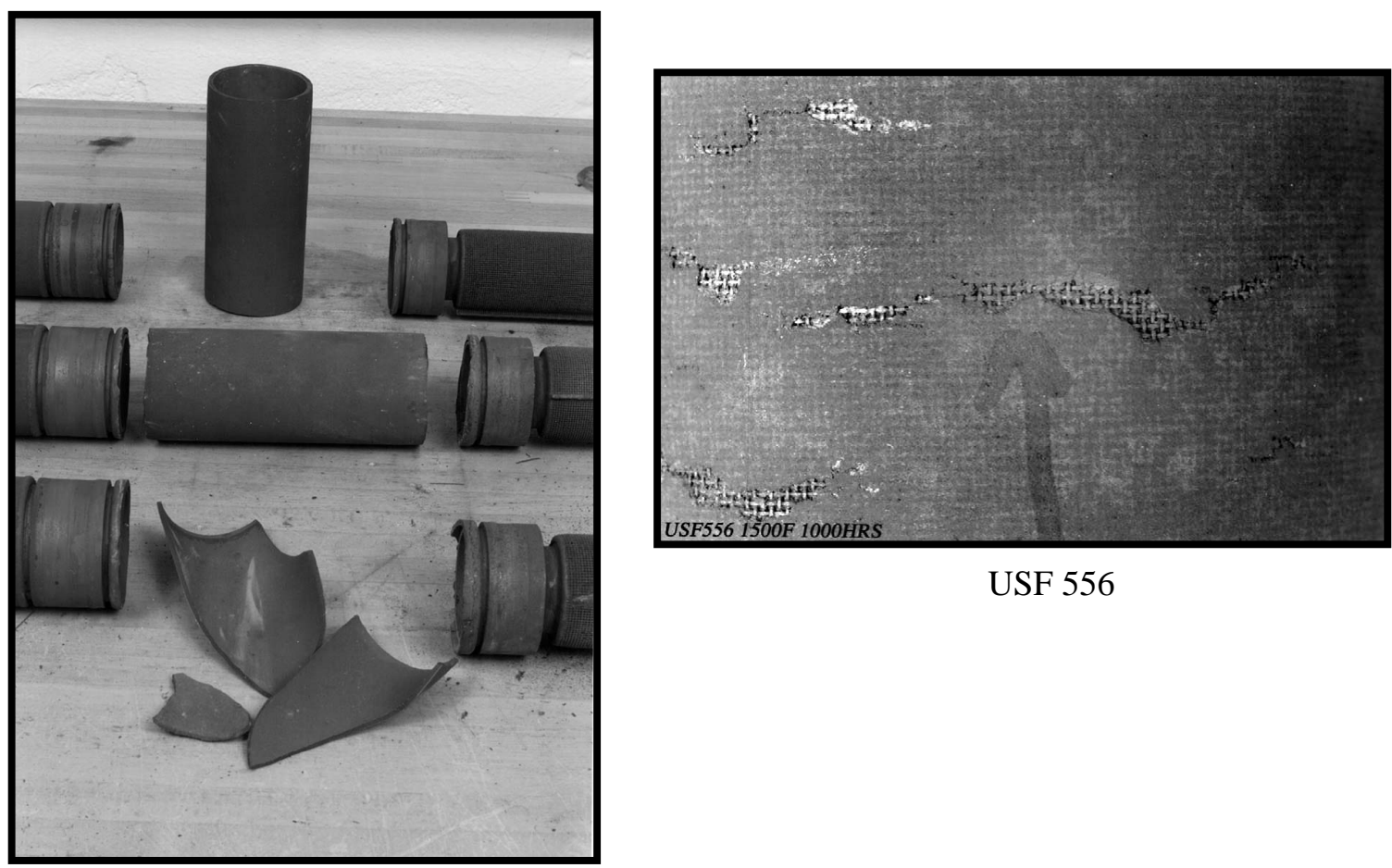

USF 556

Pall 310S

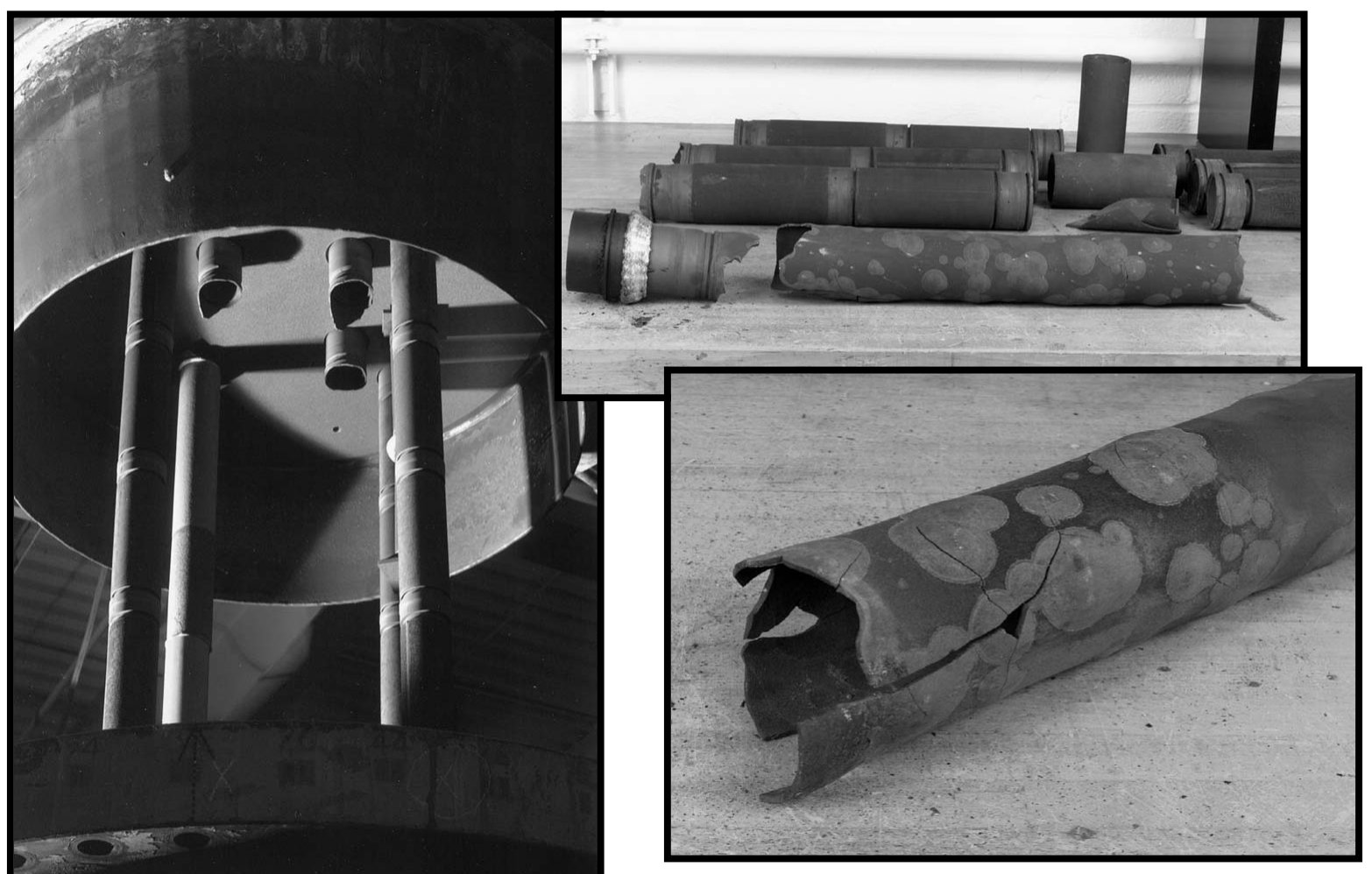

Pall FeAl

Figure 5 - Failure of porous metal filter media during simulated PFBC operation. 


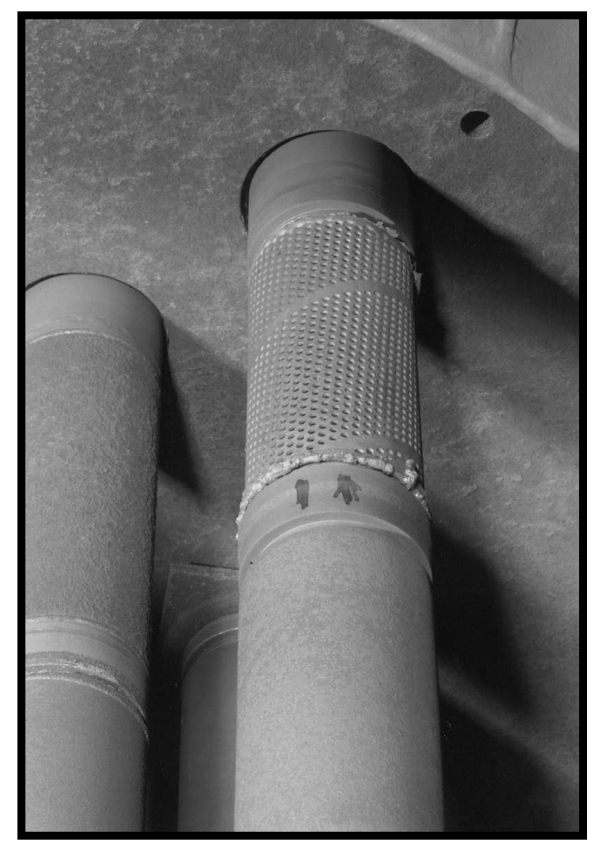

USF 214

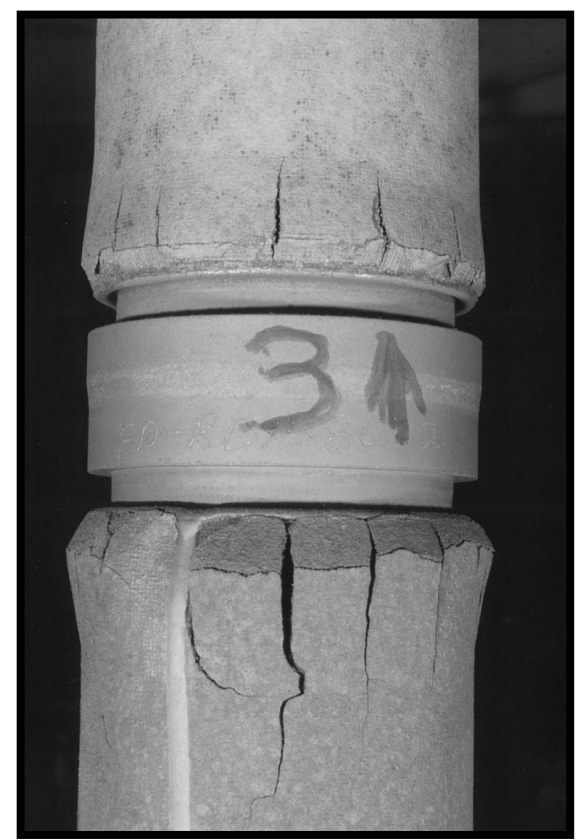

USF 556 (Top) USF 188 (Bottom)

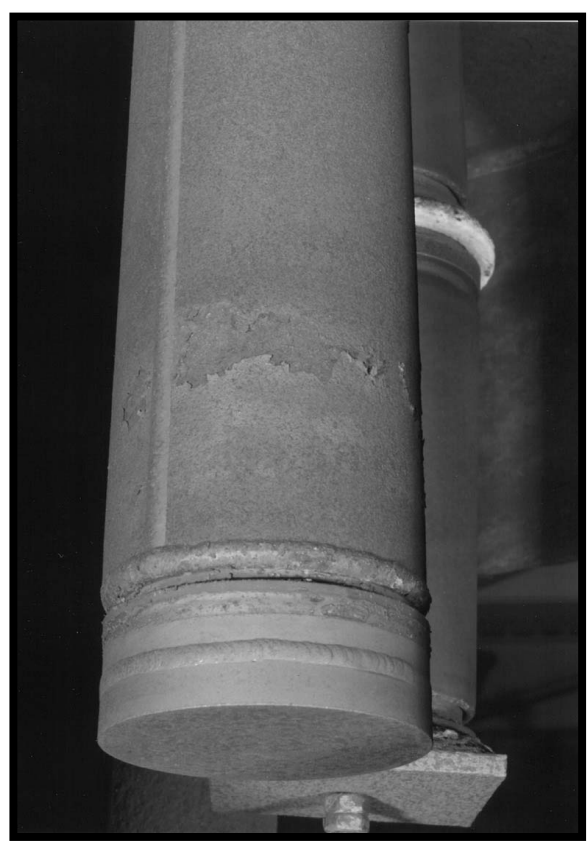

Pall Hastelloy X

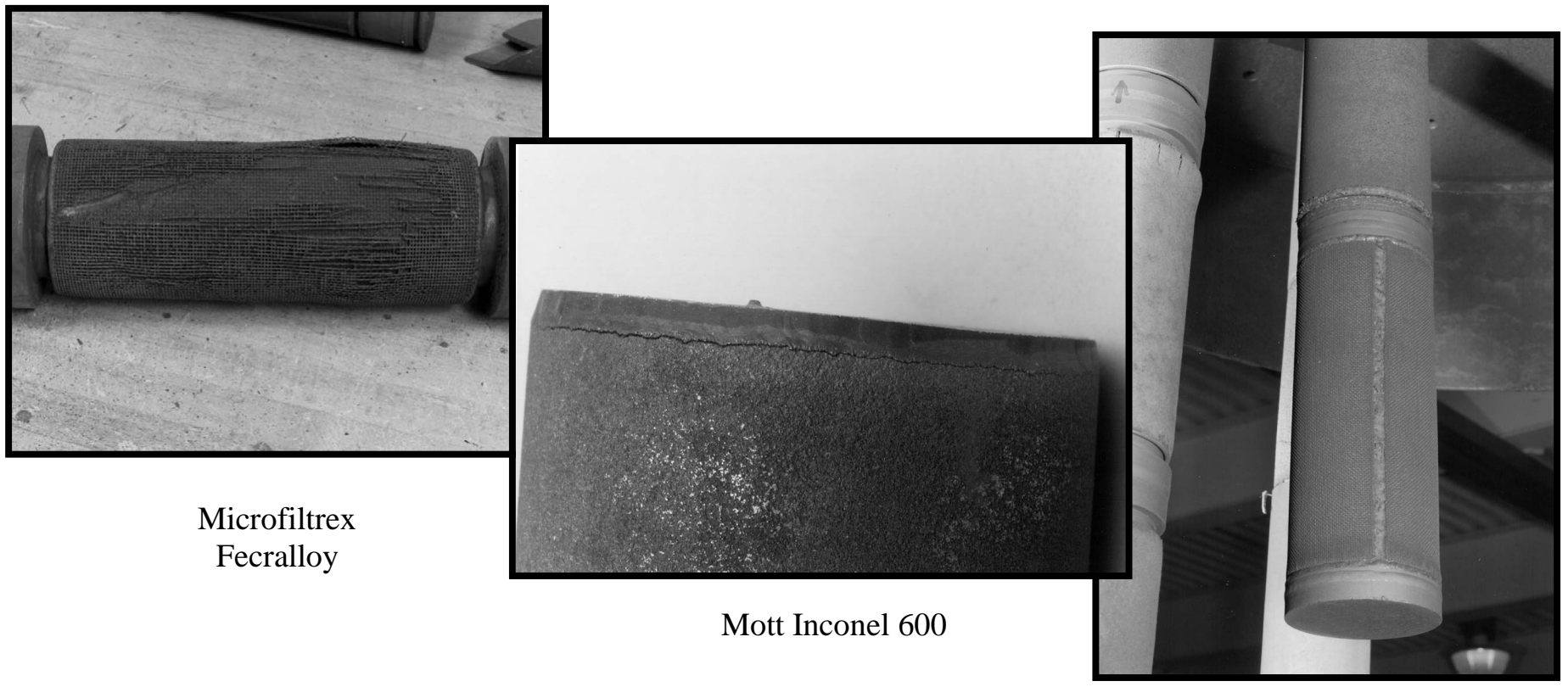

Technetics Fecralloy

Figure 5 (Cont'd.) — Failure of porous metal filter media during simulated PFBC operation. 
were cut from each filtration media, and subjected to tensile pull testing at the respective simulated PFBC process operating temperatures. As-manufactured filter media was similarly subjected to tensile strength testing at $650^{\circ} \mathrm{C}\left(1200^{\circ} \mathrm{F}\right), 760^{\circ} \mathrm{C}\left(1400^{\circ} \mathrm{F}\right)$ and $840^{\circ} \mathrm{C}\left(1550^{\circ} \mathrm{F}\right)$ in static air in order to establish the initial strength of the porous filter media. Figures 6-9 identify the impact of simulated PFBC exposure on the residual tensile strength of the porous sinter bonded filter materials. In general, as the process operating temperature increases, the strength of the porous metal filter media decreases. In addition, as-manufactured and residual process temperature strength are shown to be dependent on the architecture of the filtration media (i.e., sinter bonded fibers vs powders; monolithic filter wall vs inclusion of mesh support layers), as well as the composition of the metal alloys or intermetallic substrates used to construct the porous filter element sections.

The porous, fibrous, nickel-based, USF filter media generally tended to initially experience an increase and subsequently a reduction in tensile strength during operation in the $650^{\circ} \mathrm{C}\left(1200^{\circ} \mathrm{F}\right)$ simulated PFBC environment. With the exception of the USF Fecralloy media, an increase in tensile strength for the USF iron-based alloys was observed at $650^{\circ} \mathrm{C}\left(1200^{\circ} \mathrm{F}\right)$. The $650^{\circ} \mathrm{C}$ $\left(1200^{\circ} \mathrm{F}\right)$ tensile strength for the USF cobalt-based media remained relatively constant with time. As simulated PFBC operating temperatures were increased to $760-840^{\circ} \mathrm{C}\left(1400-1550^{\circ} \mathrm{F}\right)$, the tensile strength of the USF filter media decreased. Although dependent on the alloy or intermetallic composition, process temperature tensile strength generally stabilized with continued simulated PFBC exposure time. Typically the presence of gas phase sulfur in the $840^{\circ} \mathrm{C}\left(1550^{\circ} \mathrm{F}\right) \mathrm{PFBC}$ process gas promoted a slight further reduction in metal media tensile strength in comparison to the strength of the various USF filter materials during exposure in a sulfur-free process gas environment. In contrast, significant reduction in metal media tensile strength resulted at $840^{\circ} \mathrm{C}$ $\left(1550^{\circ} \mathrm{F}\right)$ when gas phase alkali and sulfur were present in the simulated PFBC process gas stream. Similar trends were observed for the Pall, Mott, Fairey Microfiltrex, and Technetics porous filter media. 

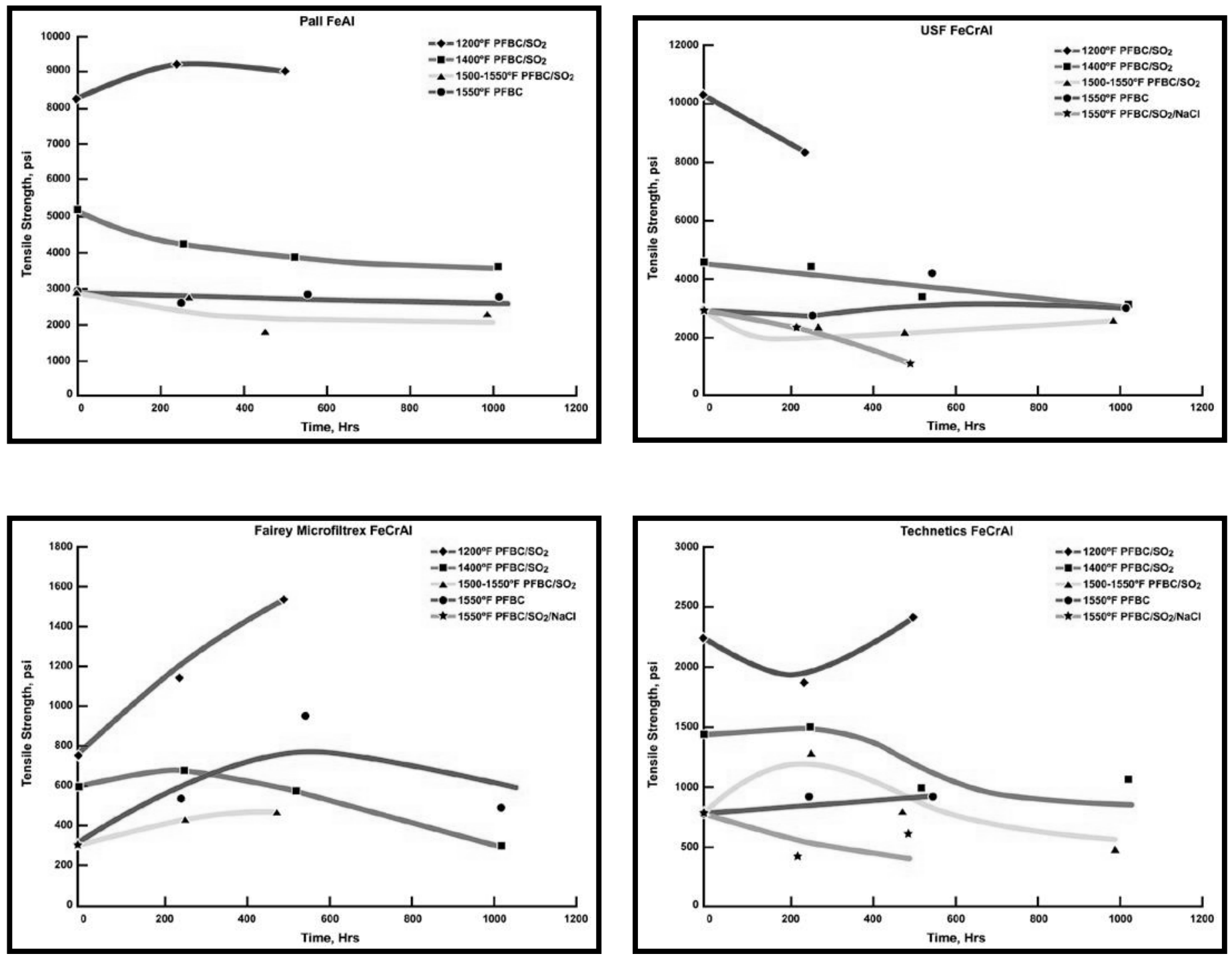

Figure 6 - Process temperature tensile strength of the iron-based, intermetallic and advanced alloy, porous filter media after exposure to simulated PFBC operating conditions. 

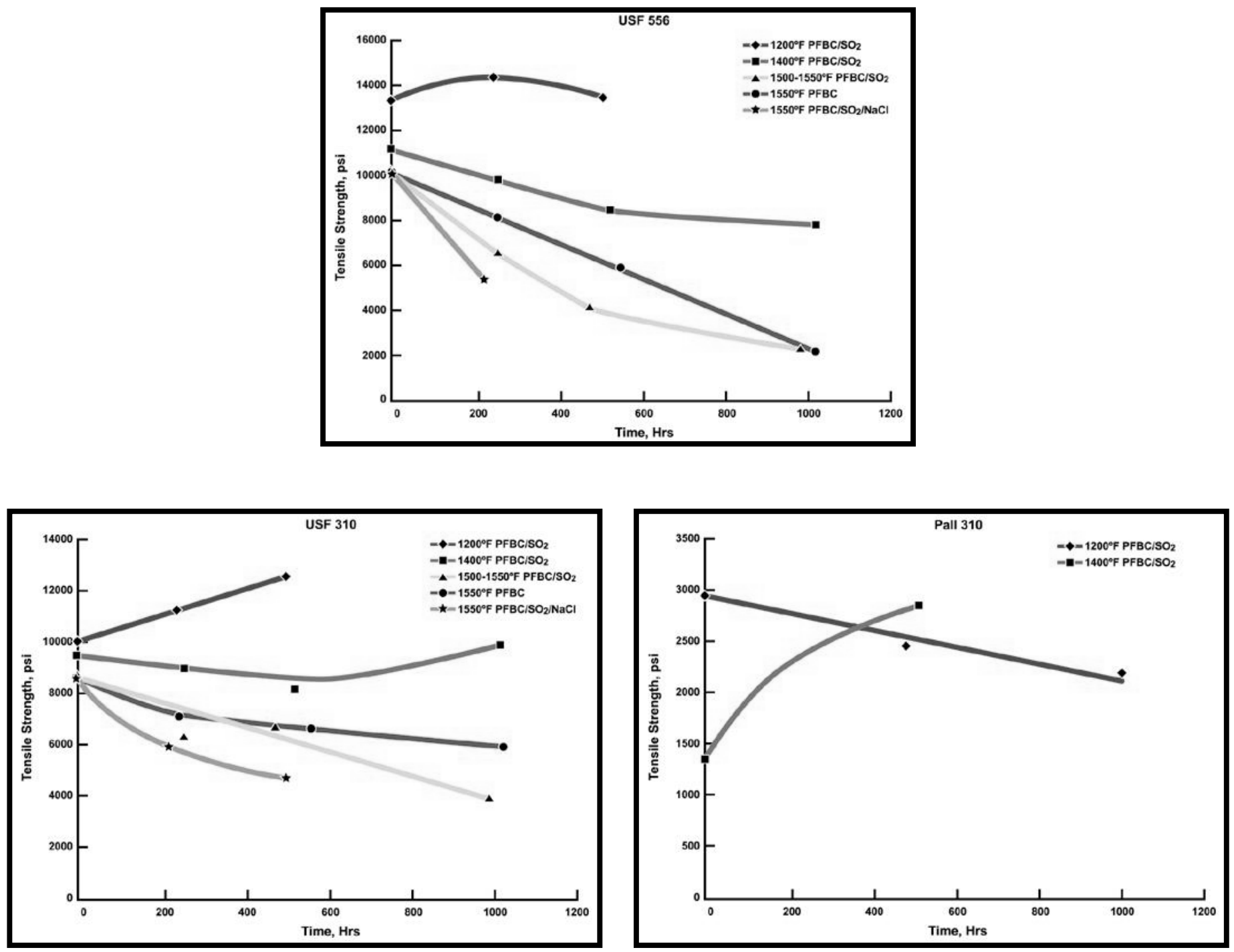

Figure 7 - Process temperature tensile strength of the iron-based, advanced and commercial alloy, porous filter media after exposure to simulated PFBC operating conditions. 

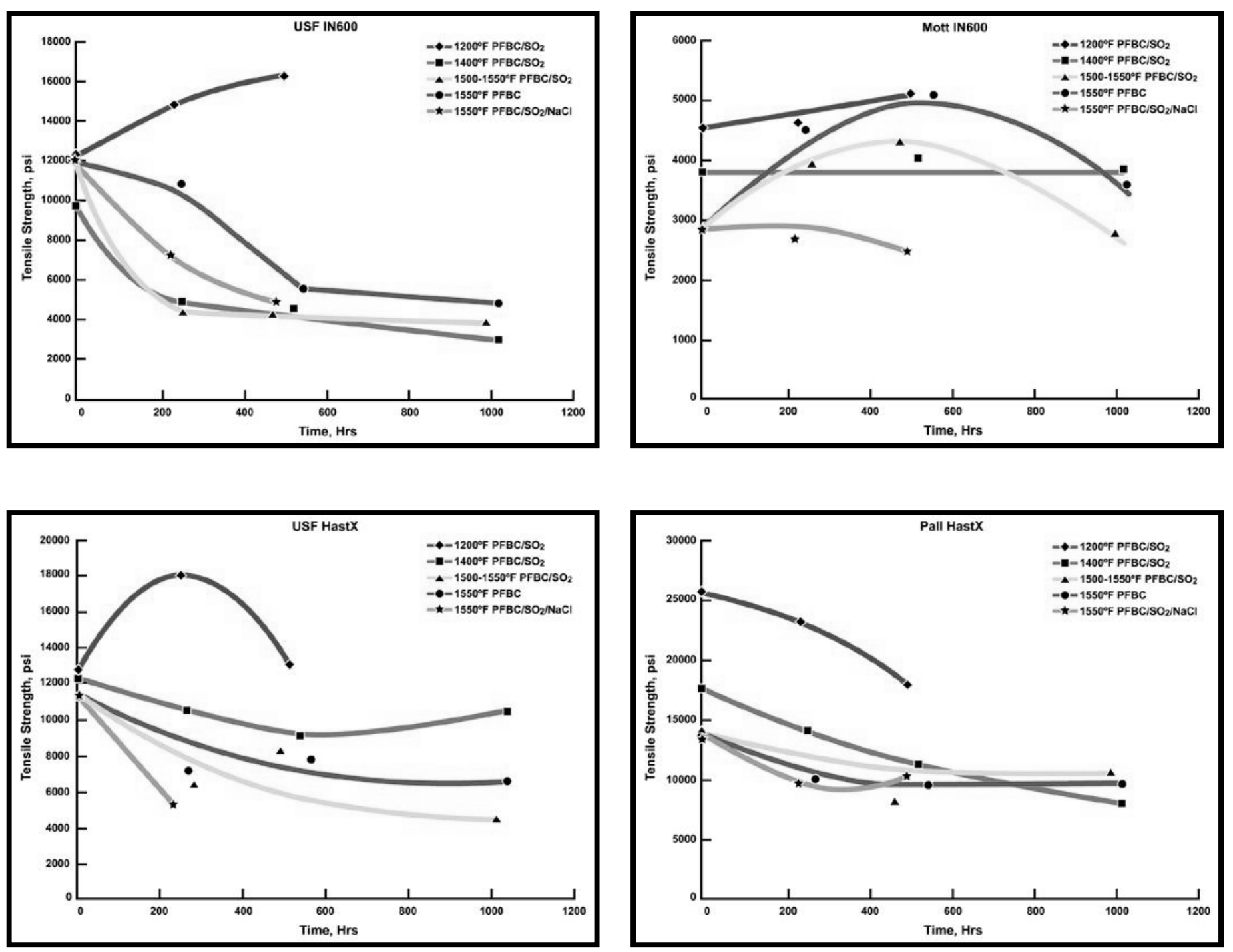

Figure 8 - Process temperature tensile strength of the nickel-based, commercial alloy, porous filter media after exposure to simulated PFBC operating conditions. 

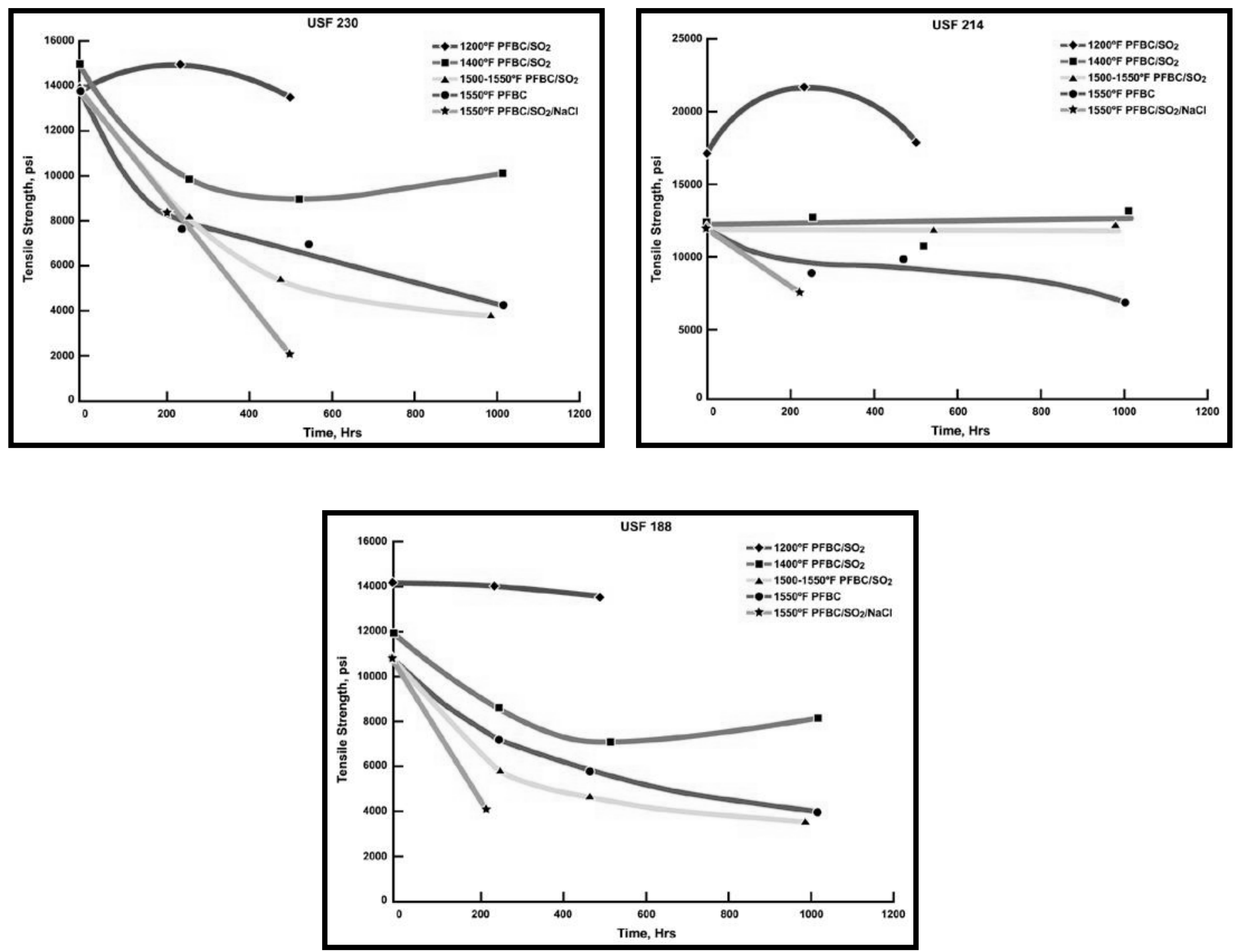

Figure 9 - Process temperature tensile strength of the nickel and cobalt-based, advanced alloy, porous filter media after exposure to simulated PFBC operating conditions. 


\subsection{MICROSTRUCTURAL ANALYSIS}

In addition to the visual observations and mechanical strength test results, post-test characterization of the various porous commercial, advanced alloy, and intermetallic filter media included scanning electron microscopy/energy dispersive x-ray analysis (SEM/EDX) of polished crosssections of the candle filter sections exposed in Test Campaigns No. 1 through No. 5. The results of this effort follow.

\subsection{Pall FeAl $-74.77 \% \mathrm{Fe}, \mathbf{2 2 . 8 5 \%} \mathrm{Al}, \mathbf{2 . 3 8 \%} \mathrm{Cr}$}

\subsubsection{Simulated PFBC Operation}

The open porosity throughout the $\sim 1.6 \mathrm{~mm}$, cross-sectioned, sinter bonded FeAl wall was retained during exposure of the Pall filter element sections to $650-840^{\circ} \mathrm{C}\left(1200-1550^{\circ} \mathrm{F}\right)$ simulated PFBC operating conditions (Test Campaign No.1 - No. 5). An $\sim 0.2 \mu \mathrm{m}$ thick alumina-enriched surface oxide formed along the outer periphery of the sinter bonded $\mathrm{FeAl}$ particles after 500 hours of exposure at $650^{\circ} \mathrm{C}\left(1200^{\circ} \mathrm{F}\right)$ (Figure 10). The thickness of the alumina-enriched surface increased to $\sim 0.5 \mu \mathrm{m}$ after 986 hours of operation at $840^{\circ} \mathrm{C}\left(1550^{\circ} \mathrm{F}\right)$ (Figure 11). Negligible intragranular oxidation was observed, while limited oxidation was detected between adjacent sinter bonded FeAl particles.
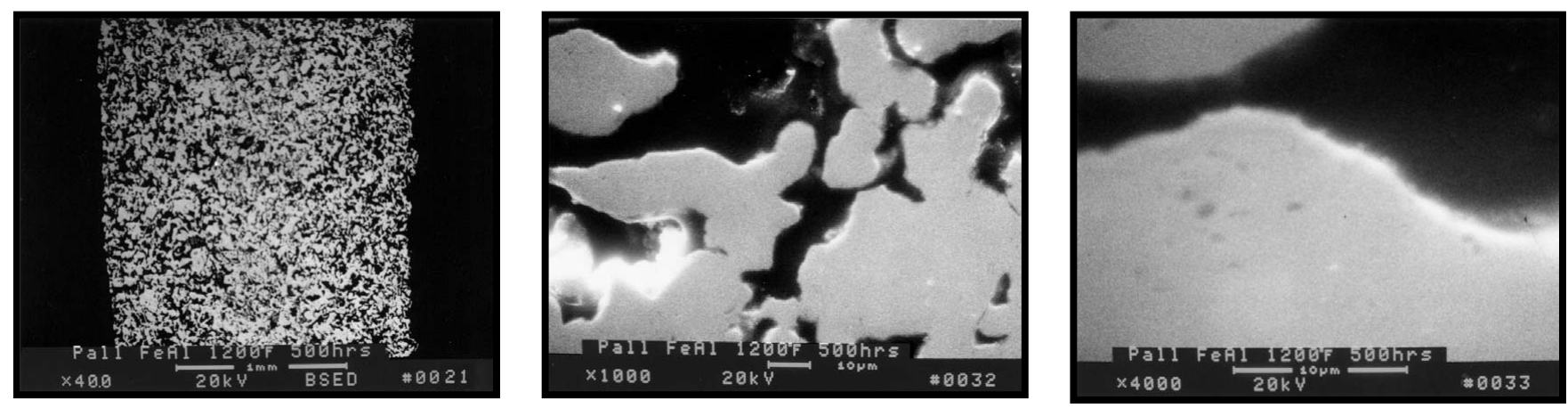

Figure 10 - Microstructure of the porous Pall FeAl filter media after 500 hours of operation in the $650^{\circ} \mathrm{C}\left(1200^{\circ} \mathrm{F}\right)$ simulated $\mathrm{PFBC}$ process gas environment.

\subsubsection{Impact of Gas Phase Alkali}

After 225 hours of exposure in the $840^{\circ} \mathrm{C}\left(1550^{\circ} \mathrm{F}\right)$, sulfur and alkali-containing, ${ }^{9}$ simulated $\mathrm{PFBC}$ environment, failure of the Pall FeAl filter media occurred. Volume expansion of the FeAl filter matrix resulting in longitudinal, as well as circumferential distortion, and generation of raised bubblelike formations with matrix cracking were evident (Figure 12). The diameter of the bubble-like formations was nominally $25 \mathrm{~mm}$, ranging between 10 and $40 \mathrm{~mm}$. An iron-sulfur-oxide-enriched

\footnotetext{
${ }^{9}$ A solution of sodium chloride was injected into the combustor gas passage, which subsequently was converted to sodium sulfate as a result of reaction with gas phase sulfur $\left(\mathrm{SO}_{2} / \mathrm{SO}_{3}\right)$ in the simulated PFBC process gas stream.
} 

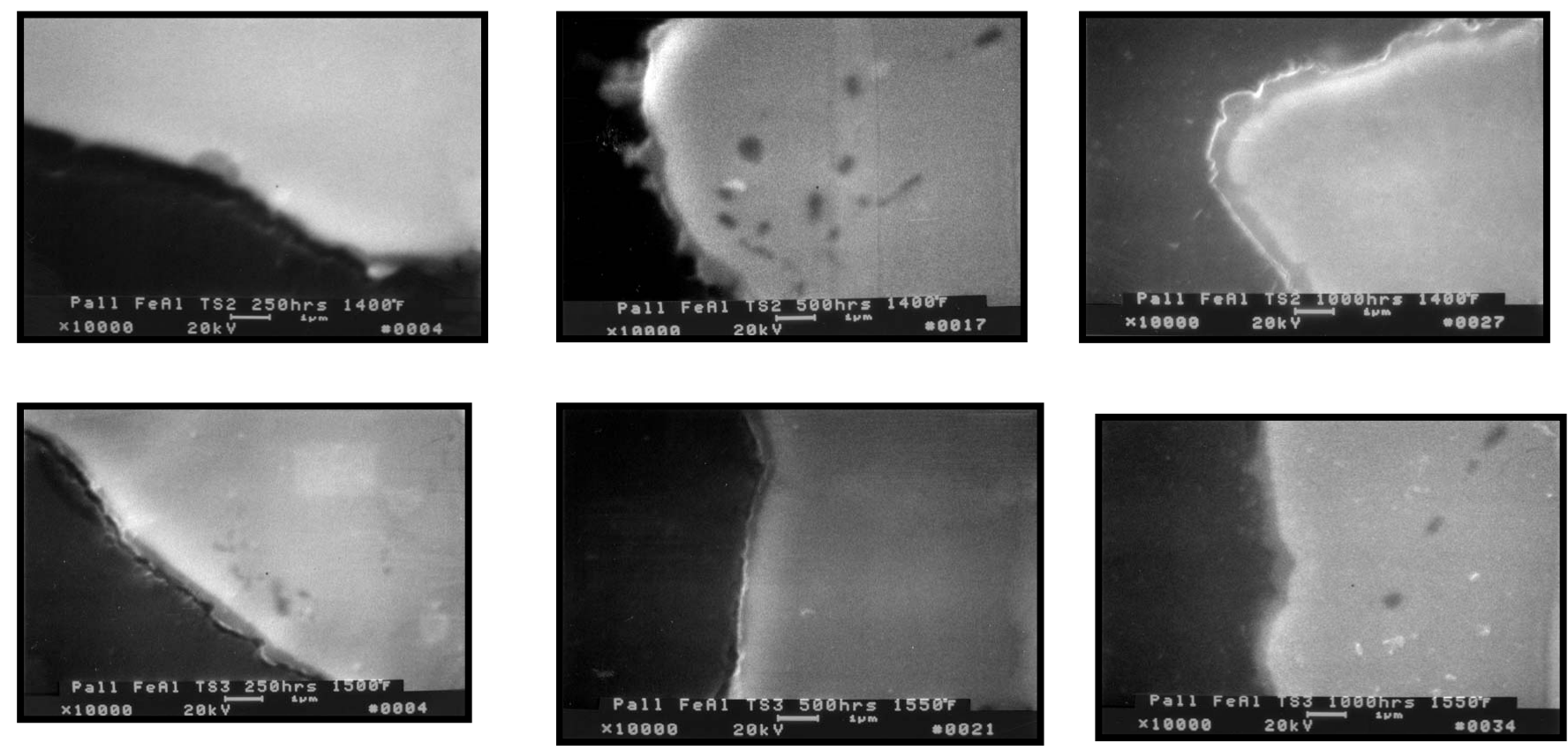

Figure 11 - Microstructure of the porous Pall FeAl filter media after 258-1016 hours of operation in the $760^{\circ} \mathrm{C}\left(1400^{\circ} \mathrm{F}\right)$ and $840^{\circ} \mathrm{C}\left(1550^{\circ} \mathrm{F}\right)$ simulated $\mathrm{PFBC}$ process gas environment.

phase formed along the outer surface of the filter media. Sodium was also detected to be present. An $\sim 0.2-0.3 \mathrm{~mm}$ "orange" band formed, defining the outer periphery of the raised bubble-like formations. The "orange" band consisted of iron oxide and sodium sulfate. Along the raised section of the bubblelike formations, $\sim 20-30 \mu \mathrm{m}$ sodium-sulfur-enriched crystals (i.e., sodium sulfate complex) were formed. Low concentrations of sulfur were present within the underlying iron oxide-enriched outer surface of the raised bubble-like formations.

When the Pall FeAl filter media was cross-sectioned, a continuous melt-like iron oxide phase was seen to have formed along the o.d. and i.d. surfaces of the filter wall, closing porosity, limiting direct passage of the process gas through the filter media (Figure 13). Similarly, the open porosity through the filter wall was reduced as a result of oxidation of the sinter bonded FeAl particles. An iron oxide $(\mathrm{FeO})$-enriched phase formed along the outer surface of the contained particles. Subsequently $\mathrm{FeAl}_{2} \mathrm{O}_{\mathrm{x}}$ and $\mathrm{FeAlO}_{\mathrm{x}}$ were formed, surrounding the underlying particle core. Sulfur was detected to be present within both iron aluminate-enriched layers. The central core of the residual FeAl particles was either a densified structure consisting principally of the base metal iron, or an internally oxidized mottled structure consisting principally of iron oxide. 

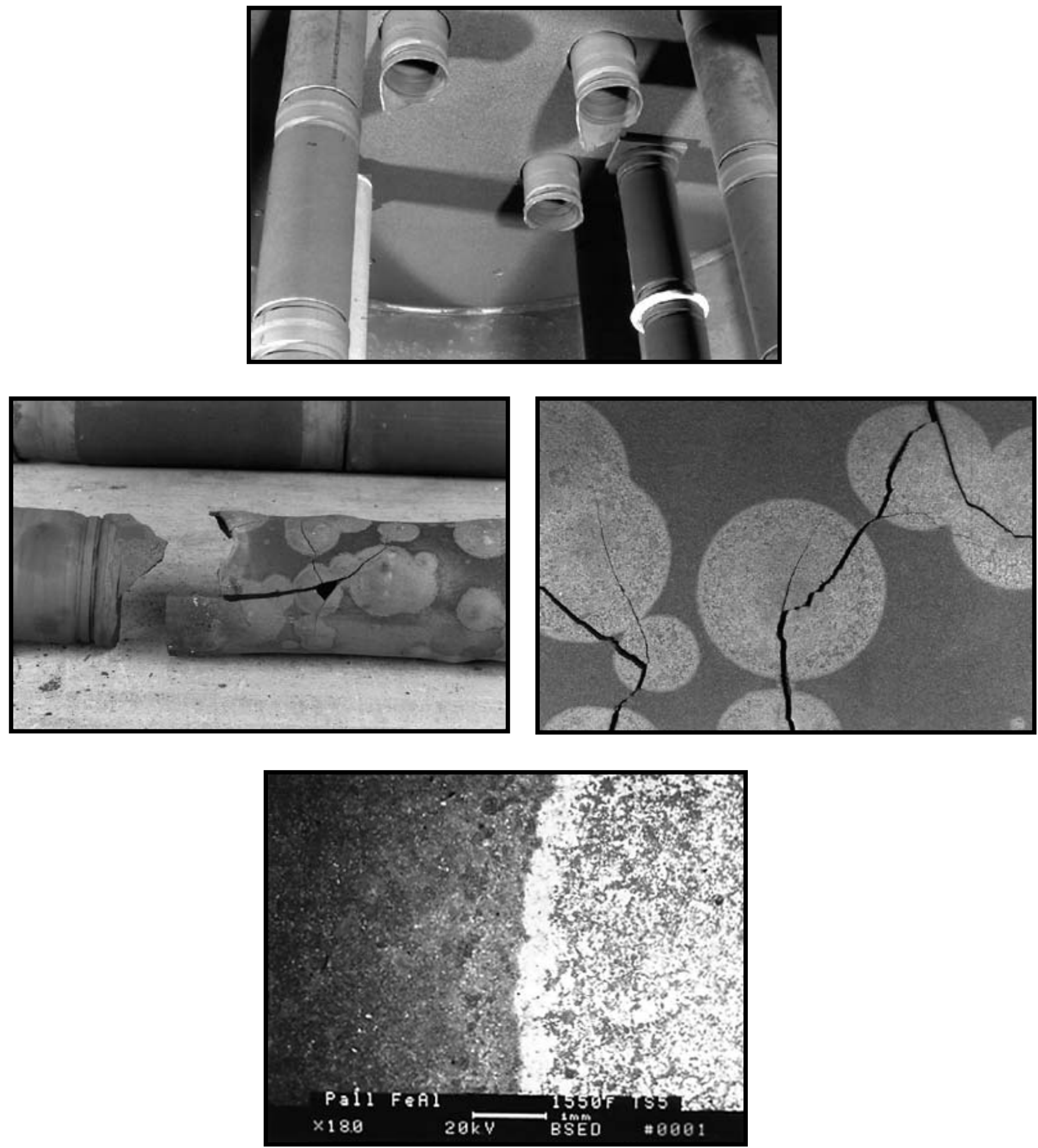

Figure 12 - Failure of the Pall FeAl filter element sections after 225 hours of exposure in the $840^{\circ} \mathrm{C}\left(1550^{\circ} \mathrm{F}\right)$ simulated $\mathrm{PFBC}$ process gas environment containing gas phase sulfur and alkali. 

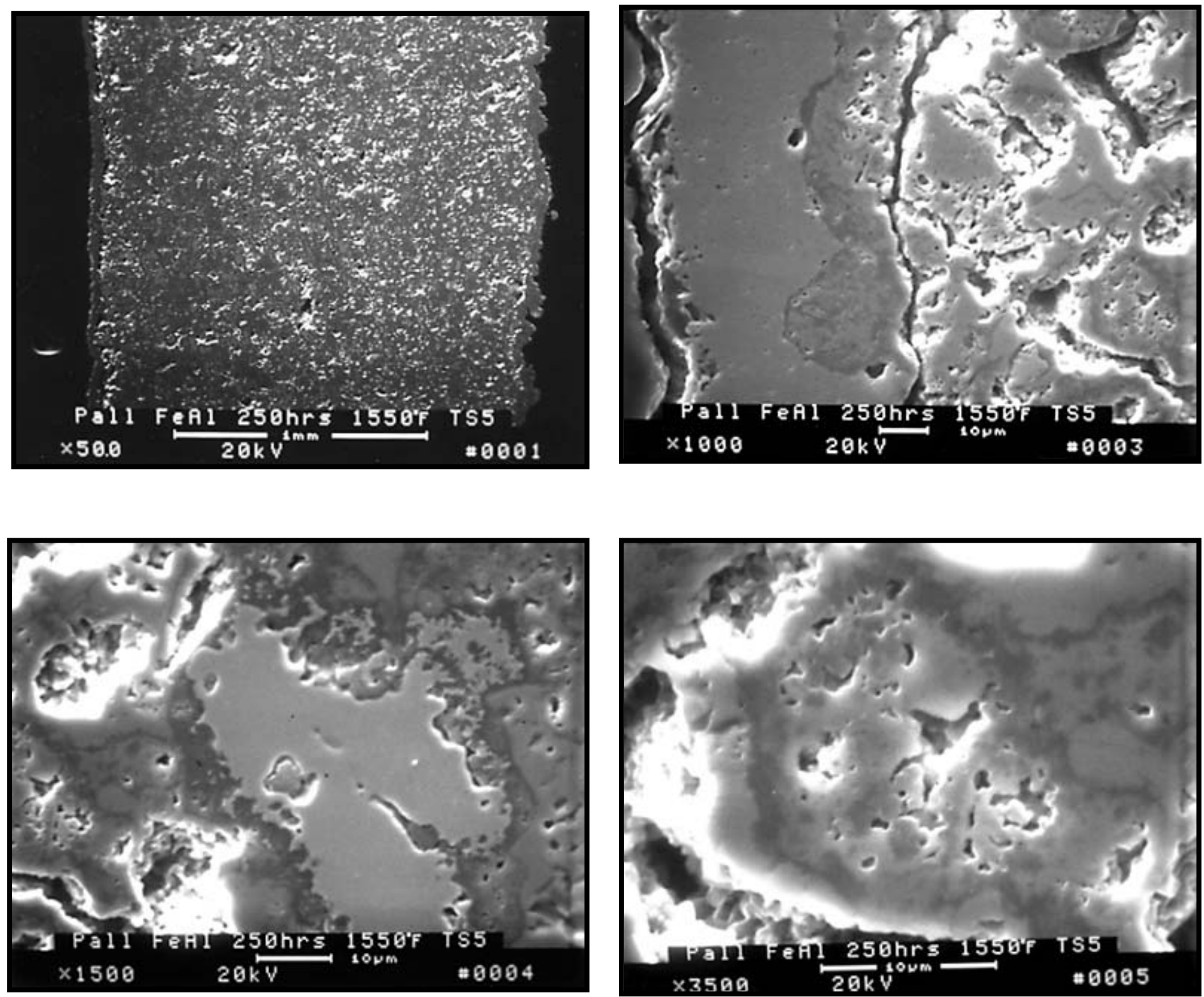

Figure 13 - Accelerated oxidation of the Pall FeAl filter media after 225 hours of exposure in the $840^{\circ} \mathrm{C}\left(1550^{\circ} \mathrm{F}\right)$ simulated $\mathrm{PFBC}$ process gas environment containing gas phase sulfur and alkali. 


\subsection{USF Fecralloy - Hoskins 875 fibers: Fe Bal; $22.5 \% \mathrm{Cr}, 5.5 \% \mathrm{Al}, \mathbf{0 . 5} \% \mathrm{Si}, 0.1 \% \mathrm{C}$}

\subsubsection{Simulated PFBC Operation}

During the initial 242 hours of operation in the $650^{\circ} \mathrm{C}\left(1200^{\circ} \mathrm{F}\right)$ simulated PFBC process gas environment, an $\sim 0.1 \mu \mathrm{m}$ thick alumina-enriched phase formed along the outer surface of the sinter bonded Fecralloy fibers in the USF filtration media. After 1016 hours of operation in the $760^{\circ} \mathrm{C}$ $\left(1400^{\circ} \mathrm{F}\right)$ simulated PFBC environment, the thickness of the alumina-enriched layer increased to $\sim 0.2-$ $0.5 \mu \mathrm{m}$. After 476 hours of operation in the $840^{\circ} \mathrm{C}\left(1550^{\circ} \mathrm{F}\right)$ simulated PFBC process gas environment, a discontinuous $\sim 1-2 \mu \mathrm{m}$ thick, alumina-iron oxide-chromia layer formed along the outer surface of the Fecralloy fibers (Figure 14). Although surface oxidation of the Fecralloy fibers occurred, the open porosity of the USF filtration media was retained. During simulated PFBC testing, internal oxidation of the Fecralloy fibers was not observed. Negligible oxidation resulted along the fibrous sinter bond interface.

\subsubsection{Impact of Gas Phase Alkali}

In contrast, the open porosity of the USF Fecralloy filter media was limitedly retained after 225 hours of operation in the $840^{\circ} \mathrm{C}\left(1550^{\circ} \mathrm{F}\right)$ simulated $\mathrm{PFBC}$ process gas environment that contained both gas phase sulfur and alkali (Figure 15). Alumina-enriched, $\sim 2-3 \mu \mathrm{m}$, needle-like whisker formations resulted along the outer surface of the Fecralloy fibers and Fecralloy structural support mesh. Internal oxidation was not observed throughout the sinter bonded USF Fecralloy fibers.

After 496 hours of operation in the $840^{\circ} \mathrm{C}\left(1550^{\circ} \mathrm{F}\right)$ simulated PFBC process gas environment, the microstructure of the USF Fecralloy fibrous filtration mat was no longer retained due to oxidation and coalescence of the originally porous, fibrous, metal media. Gas flow permeability through the oxidized filtration mat was expected to be severely restricted. Surface and subsurface void formations frequently resulted along the periphery of the USF Fecralloy structural support mesh after 496 hours of operation in the gas phase sulfur and alkali-containing, simulated PFBC process gas environment. Limited sulfation was seen to have resulted within chromia-enriched phases that were embedded within the coalesced USF Fecralloy fibrous media.

\subsection{USF Haynes $230-57 \% \mathrm{Ni}, 22 \% \mathrm{Cr}, 14 \% \mathrm{~W}, 5 \% \mathrm{Co}, 3 \% \mathrm{Fe}, 0.1 \% \mathrm{C}, 0.4 \% \mathrm{Si}$, $0.5 \%$ Mn, $0.02 \%$ La, $0.015 \%$ B, $2 \%$ Mo, $0.3 \%$ Al}

\subsubsection{Simulated PFBC Operation}

The open porosity of the USF Haynes 230 was retained after 500 hours of operation in the $650^{\circ} \mathrm{C}$ $\left(1200^{\circ} \mathrm{F}\right.$ ) simulated PFBC process gas environment (Figure 16). An $\sim 2.5-3.0 \mu \mathrm{m}$ thick oxygenchromium-nickel-enriched layer formed along the surface of the sinter bonded Haynes 230 fibers. Internal oxidation of the fibers was initiated.

Oxidation similarly resulted along the outer surface of the sinter bonded Haynes 230 fibers in the USF filtration media after 258 hours of operation in the $760^{\circ} \mathrm{C}\left(1400^{\circ} \mathrm{F}\right)$ simulated PFBC process gas environment. The open porosity of the filtration media appeared to have been retained during the initial 258 hours of exposure, but may have been limited after 524.5 and 1016 hours of operation. With time, an $\sim 3-5.5 \mu \mathrm{m}$ thick oxide scale formed along the outer surface of the Haynes 230 fibers in the USF filtration media. 

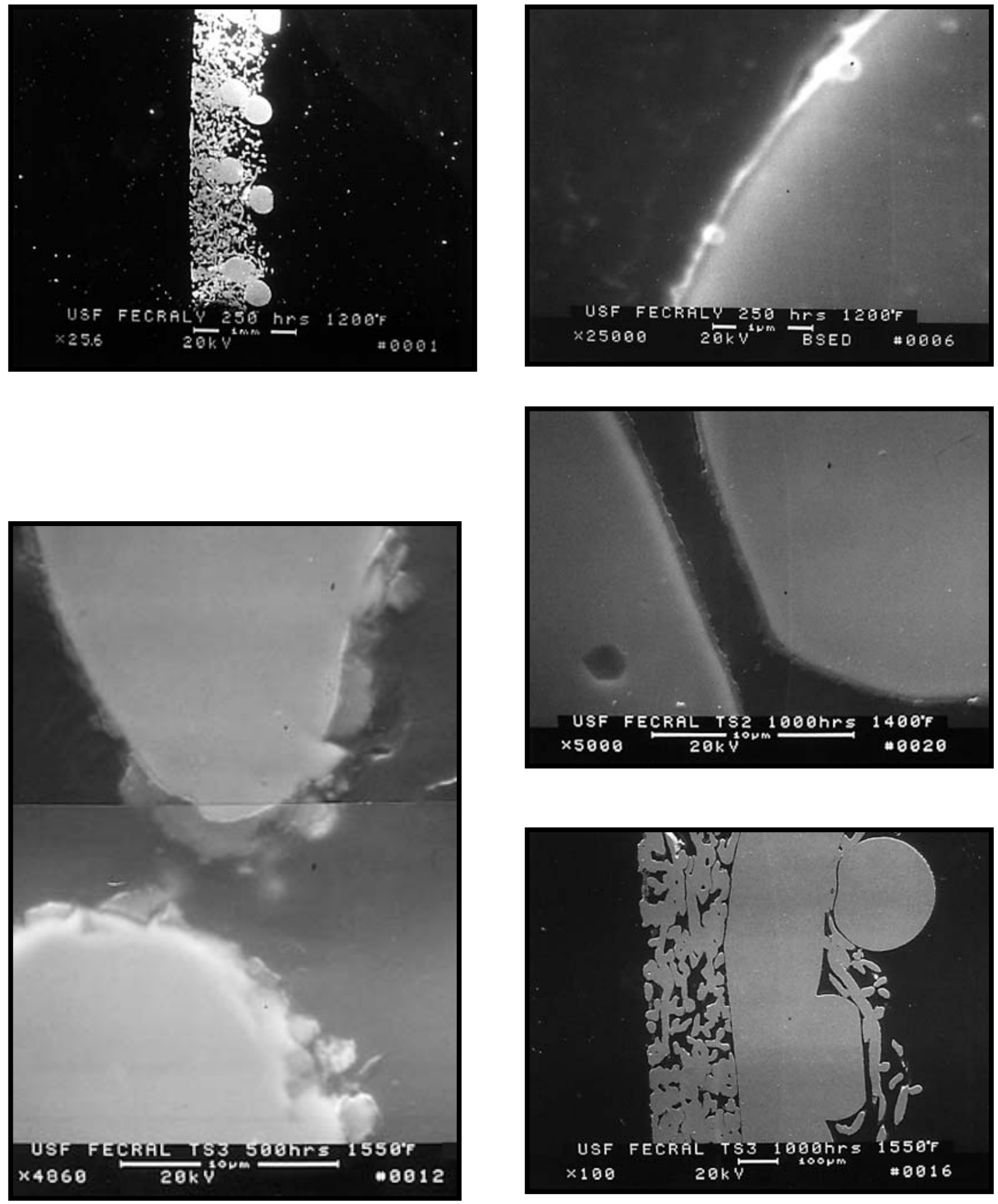

Figure 14 - Morphology of the USF Fecralloy filter media after exposure to $650-840^{\circ} \mathrm{C}(1200$ $1550^{\circ} \mathrm{F}$ ) simulated $\mathrm{PFBC}$ operating conditions. 

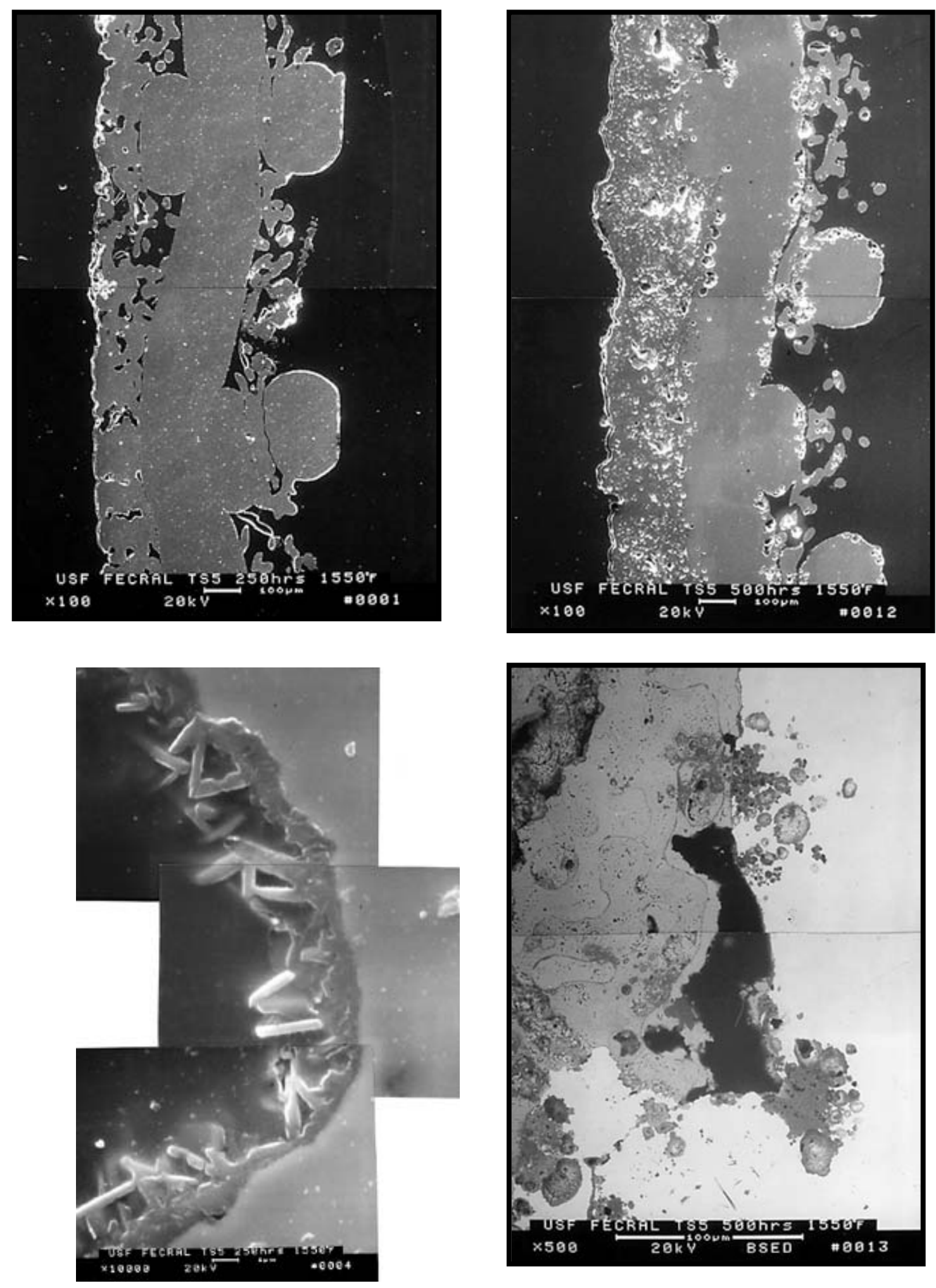

Figure 15 - Morphology of the USF Fecralloy filtration media after exposure to $840^{\circ} \mathrm{C}\left(1550^{\circ} \mathrm{F}\right)$ simulated PFBC operating conditions containing gas phase sulfur and alkali. 

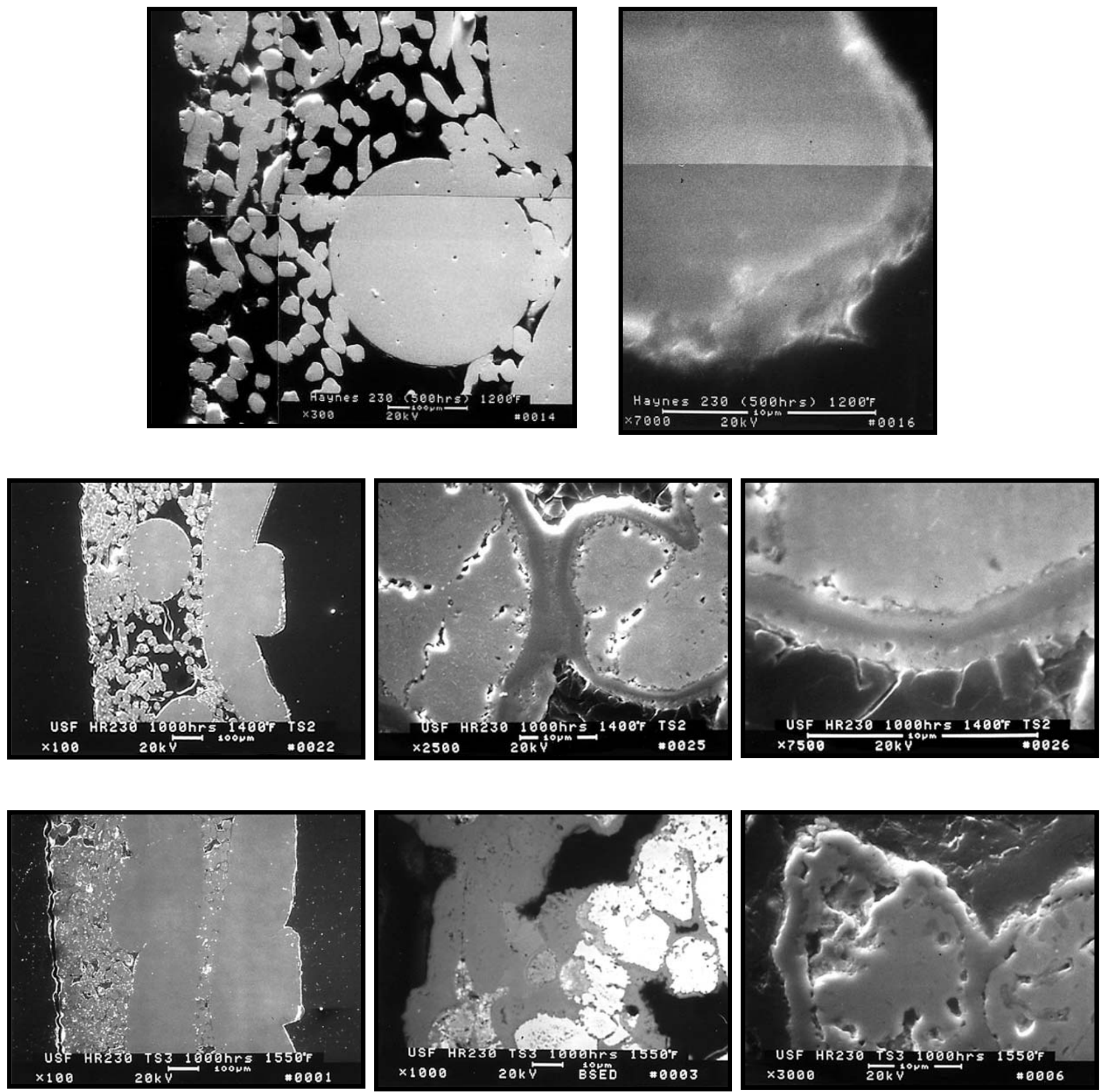

Figure 16 - Morphology of the USF Haynes 230 filter media after exposure to $650-840^{\circ} \mathrm{C}(1200$ $1550^{\circ} \mathrm{F}$ ) simulated PFBC operating conditions. 
At $760^{\circ} \mathrm{C}\left(1400^{\circ} \mathrm{F}\right)$, an external nickel oxide layer initially formed along the outer surface of the Haynes 230 fibers. Subsurface layers were enriched with chromia and minor concentrations of nickel, and a nickel chromate spinel. After 524.5 hours, iron was seen to be present within a thin band that formed between the external nickel oxide and chromia-enriched layers. Along the i.d. or pulse cycled surface of the USF Haynes 230 filter element, a thicker (i.e., $\sim 2 \mu \mathrm{m}$ ) oxygen-nickel-ironenriched layer formed along the outer surface of the USF Haynes 230 fibers. As the simulated PFBC exposure time was extended to 1016 hours, nickel oxide was identified as the primary phase along the outer surface of the Haynes 230 fibers, with minor concentrations of nickel present within an underlying chromia-enriched subsurface layer.

After 259 hours of operation in the $815^{\circ} \mathrm{C}\left(1500^{\circ} \mathrm{F}\right)$ simulated PFBC process gas environment, oxidation similarly resulted within the USF Haynes 230 filtration media. The open porosity of the filtration media appeared to have been retained during the initial 259 hours of operation, but may have been limited after 986 hours of exposure in the $815-840^{\circ} \mathrm{C}\left(1500-1550^{\circ} \mathrm{F}\right)$ simulated PFBC environment. With time, an $~ 1.5-6 \mu \mathrm{m}$ thick oxide scale formed along the outer surface of the 815 $840^{\circ} \mathrm{C}\left(1500-1550^{\circ} \mathrm{F}\right)$, simulated PFBC-exposed, Haynes 230 fibers in the USF filtration media. A continuous, $\sim 10-30 \mu \mathrm{m}$ thick, iron-nickel oxide spinel or nickel oxide layer formed along the o.d. surface of the Haynes 230 filtration media.

Microstructural characterization of the Haynes 230 fibers within the USF filtration media indicated that the fibers were encapsulated with an external chromia-enriched layer, and a subsurface chrome-nickel oxide layer after 259 hours of exposure in the $815^{\circ} \mathrm{C}\left(1500^{\circ} \mathrm{F}\right)$ simulated PFBC environment. After 476 hours of exposure at $815-840^{\circ} \mathrm{C}\left(1500-1550^{\circ} \mathrm{F}\right)$, a nickel oxide or nickel-iron oxide layer, and a subsurface chromia layer formed along the outer surface of the Haynes 230 fibers. After 986 hours of exposure, the outer surface of the oxide was enriched with either a chromium-ironnickel spinel or a nickel-chromate complex. Chromia was present as the primary subsurface oxide phase.

Void formations were evident along the oxide/base metal interface of the USF Haynes 230 fibers. With continued exposure time at $760^{\circ} \mathrm{C}\left(1400^{\circ} \mathrm{F}\right)$ and $815-840^{\circ} \mathrm{C}\left(1500-1550^{\circ} \mathrm{F}\right)$, this became more pronounced. Intragranular oxidation within Haynes 230 fibers, oxidation between sinter bonded Haynes 230 fibers, as well as oxidation at the Haynes 230 fiber/Hastelloy X structural support mesh interface resulted during exposure of the USF filtration media in the $760^{\circ} \mathrm{C}\left(1400^{\circ} \mathrm{F}\right)$ and $815-840^{\circ} \mathrm{C}$ $\left(1500-1550^{\circ} \mathrm{F}\right)$ simulated $\mathrm{PFBC}$ process gas environment.

A Hastelloy X structural support mesh was used in the manufacture of the USF Haynes 230 filtration media. An $\sim 3-6 \mu \mathrm{m}$ thick oxide scale formed along the outer surface of the $760^{\circ} \mathrm{C}\left(1400^{\circ} \mathrm{F}\right)$, simulated PFBC-exposed, Hastelloy X structural support mesh. Between 258 and 524.5 hours of simulated PFBC exposure, the outer surface of the oxide layer was enriched with oxygen-nickel-iron. Subsurface layers consisted primarily of oxygen-chromium-nickel, and subsequently chromia. After 1016 hours of simulated PFBC operation, the composition of the oxide layer was seen to be enriched with nickel oxide along the outer surface of the scale, followed by an oxygen-nickel-iron-enriched layer, and subsequently a chromia-enriched layer.

In the $815-840^{\circ} \mathrm{C}\left(1500-1550^{\circ} \mathrm{F}\right)$, simulated PFBC-exposed, USF Haynes 230 filter media, an $\sim 1-10 \mu \mathrm{m}$ thick oxide layer formed along the outer surface of the Hastelloy X, structural support mesh. Within the initial 259 hours of operation, the oxide layer consisted of chrome-nickel spinel. After 476 and 986 hours of exposure, the external chrome-nickel spinel became enriched with iron, while a chromia-enriched subsurface oxide formed. 


\subsubsection{Impact of Gas Phase Alkali}

In the presence of gas phase alkali, oxidation resulted along the outer surface of the Haynes 230 fibers after 225 hours of operation in the $840^{\circ} \mathrm{C}\left(1550^{\circ} \mathrm{F}\right)$ simulated $\mathrm{PFBC}$ process gas environment, limiting the open porosity of the filtration media (Figure 17). Internal oxidation and numerous voids were observed along the cross-sectioned surface of the Haynes 230 fibers. With continued exposure (i.e., 496 hours of operation), extensive oxidation was seen to have resulted along the o.d. surface of the filter element sections, as well as within the filtration mat, severely limiting the open porosity of the USF Haynes 230 filter media.

The thickness of the oxide layer that formed along the outside surface of the Haynes 230 fibers tended to increase with continued operation in the $840^{\circ} \mathrm{C}\left(1550^{\circ} \mathrm{F}\right)$ simulated PFBC environment (i.e., $\sim 1-25 \mu \mathrm{m}$ after 225 hours; $~ 25-50 \mu \mathrm{m}$ after 496 hours). The outer surface layer of the oxide after both 225 and 496 hours of operation was enriched with nickel and oxygen. Subsurface oxides consisted of oxygen-chromium-nickel-iron phases.

The thickness of the oxide layer that formed along the outer surface of the Hastelloy $\mathrm{X}$ structural support mesh in the USF Haynes 230 filter media tended to remain constant after 225 and 496 hours of exposure in the $840^{\circ} \mathrm{C}\left(1550^{\circ} \mathrm{F}\right)$, alkali-laden, simulated PFBC process gas environment (i.e., $\sim 4.25 \mu \mathrm{m}$ and $\sim 5 \mu \mathrm{m}$, respectively). The composition of the outer surface of the oxide was enriched with oxygen-nickel-chromium. Within the 496 hour-exposed, Hastelloy X structural support mesh, a subsurface chromia layer was identified.

\subsection{USF Haynes $214-75 \% \mathrm{Ni}, 16 \% \mathrm{Cr}, 3 \% \mathrm{Fe}, 0.05 \% \mathrm{C}, 0.2 \% \mathrm{Si}, 0.5 \% \mathrm{Mn}, 0.01 \% \mathrm{~B}$, $4.5 \% \mathrm{Al}, 0.1 \% \mathrm{Zr}, 0.01 \% \mathrm{Y}$}

\subsubsection{Simulated PFBC Operation}

Limited oxidation resulted within the USF Haynes 214 filter media after 242-500 hours of exposure to the $650^{\circ} \mathrm{C}\left(1200^{\circ} \mathrm{F}\right)$ simulated PFBC operating condition (Figure 18). An $<0.5 \mu \mathrm{m}$ thick scale formed along the external surface of the Haynes 214 fibers that was enriched with nickel oxide. As the thickness of the oxide scale increased to $0.75-1.5 \mu \mathrm{m}$, a chromium-iron oxideenriched external surface scale formed. After extended exposure (i.e., 500 hours), the chromiumiron oxide phase tended to result as the primary phase throughout the $<0.5-1.5 \mu \mathrm{m}$ scale that formed along the outer surface of the Haynes 214 fibers.

Pitting along the external surface of the oxidized Haynes 214 fibers was frequently observed after 500 hours of operation in the $650^{\circ} \mathrm{C}\left(1200^{\circ} \mathrm{F}\right)$ simulated PFBC environment. Similarly, sulfur was observed in isolated areas within the external surface oxide, as well as within the internal inclusions of the Haynes 214 matrix. Void formations along the sinter bond interface that formed between adjacent Haynes 214 fibers were frequently detected, particularly after 500 hours of simulated PFBC testing.

After $258-1016$ hours of operation in the $760^{\circ} \mathrm{C}\left(1400^{\circ} \mathrm{F}\right)$ simulated PFBC process gas environment, the open porosity remained within the USF Haynes 214 filtration media. An external oxide layer formed along the outer surface of the simulated PFBC-exposed Haynes 214 fibers, and whisker-like void formations were clearly evident along the internal periphery of the crosssectioned Haynes 214 fibers (Figure 19). Internal oxidation of the Haynes 214 fibers was also observed. 

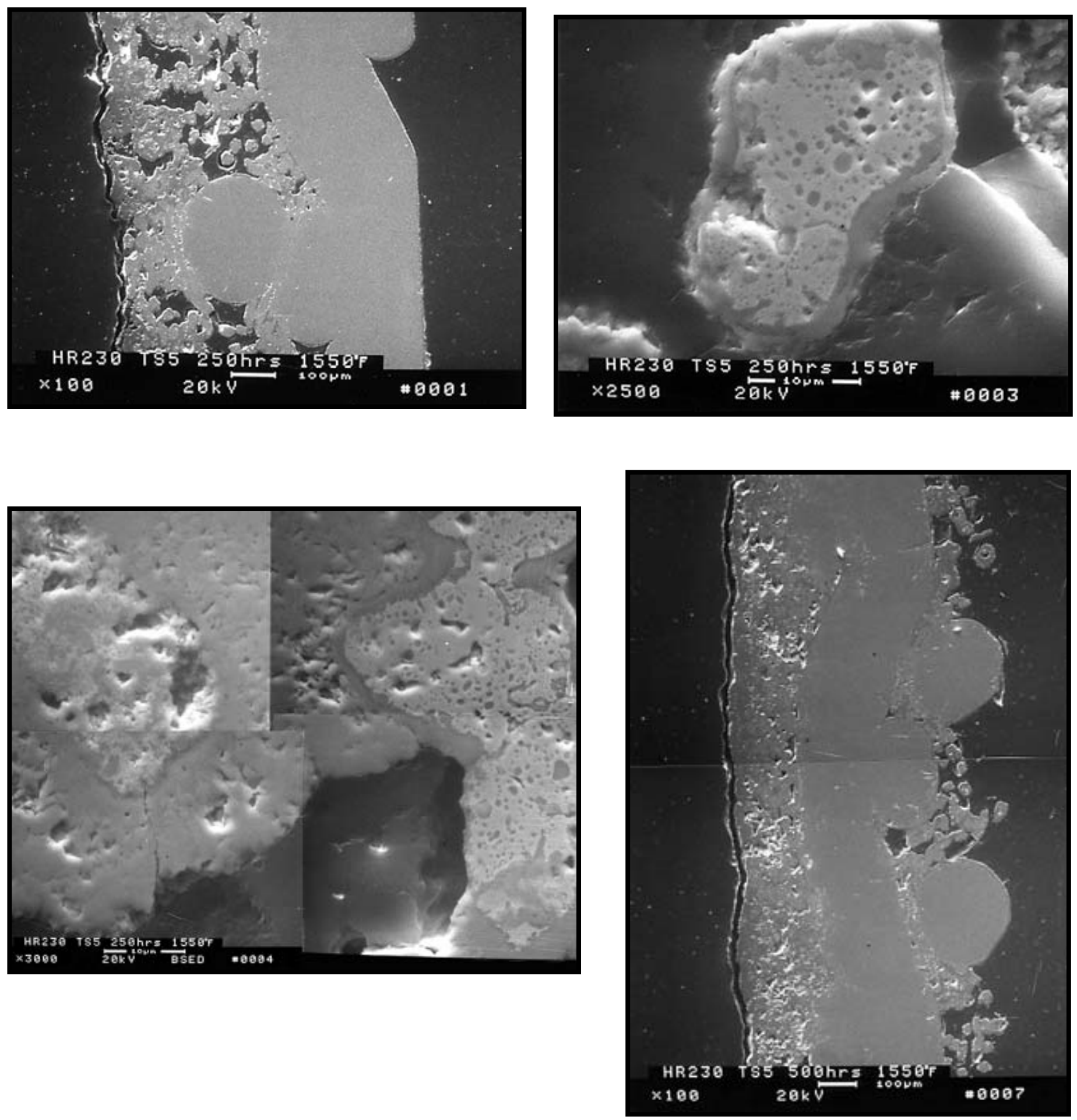

Figure 17 - Morphology of the USF Haynes 230 filtration media after exposure to $840^{\circ} \mathrm{C}$ $\left(1550^{\circ} \mathrm{F}\right)$ simulated $\mathrm{PFBC}$ operating conditions containing gas phase sulfur and alkali. 

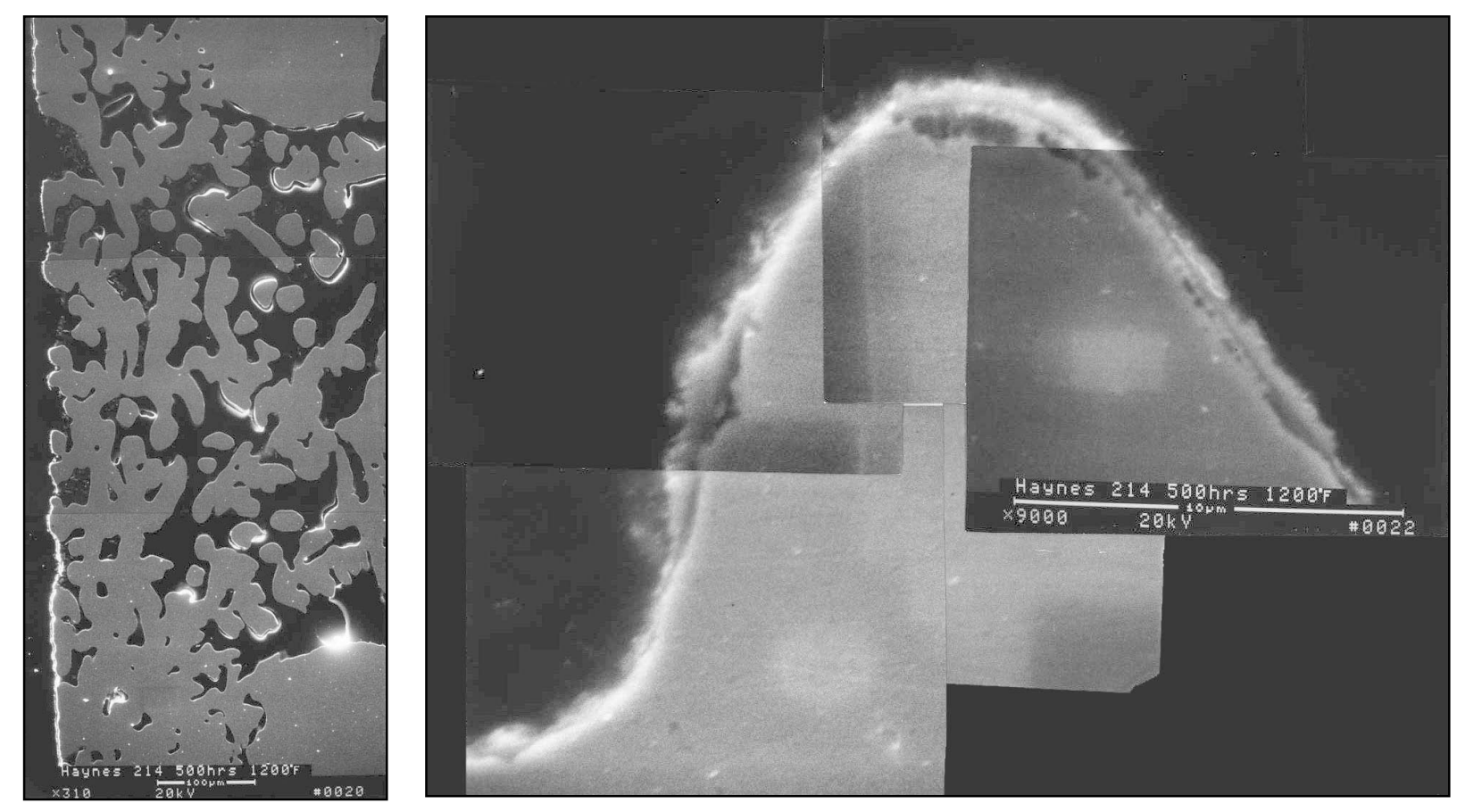

Figure 18 - Morphology of the USF Haynes 214 filtration media after 500 hours of operation in the $650^{\circ} \mathrm{C}\left(1200^{\circ} \mathrm{F}\right)$ simulated $\mathrm{PFBC}$ process gas environment.

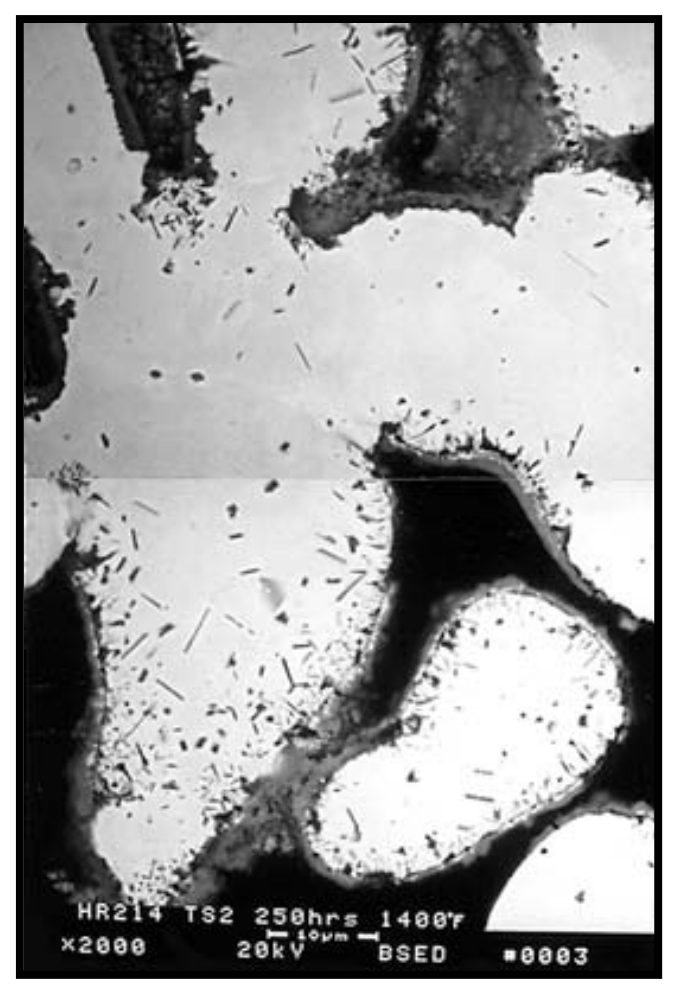

Figure 19 - Morphology of the USF Haynes 214 filtration media after 258 hours of operation in the $760^{\circ} \mathrm{C}\left(1400^{\circ} \mathrm{F}\right)$ simulated $\mathrm{PFBC}$ process gas environment. 
After 258 hours of operation in the $760^{\circ} \mathrm{C}\left(1400^{\circ} \mathrm{F}\right)$ simulated $\mathrm{PFBC}$ process gas environment, an $\sim 1.9 \mu \mathrm{m}$ thick oxide layer formed along the outer surface of the cross-sectioned USF Haynes 214 fibers. The external oxide surface contained $\mathrm{O}-\mathrm{Cr}-\mathrm{Ni}$, with an underlying $\mathrm{O}-\mathrm{Ni}$ Cr-enriched subsurface layer. After 524.5 hours of operation in the $760^{\circ} \mathrm{C}\left(1400^{\circ} \mathrm{F}\right)$ simulated PFBC environment, chromia-enrichment was observed along external surface of the $\sim 1.5 \mu \mathrm{m}$ thick oxide layer. The underlying subsurface was O-Ni-Al-Cr-enriched. After 1016 hours of operation, the $\sim 2.1-3.1 \mu \mathrm{m}$ thick oxide consisted of an external chromia-enriched layer and an underlying $\mathrm{O}-$ $\mathrm{Ni}-\mathrm{Cr}$-enriched layer. An O-Cr-Ni phase was identified within the oxidized islands that penetrated into the base metal substrate (Figure 20).

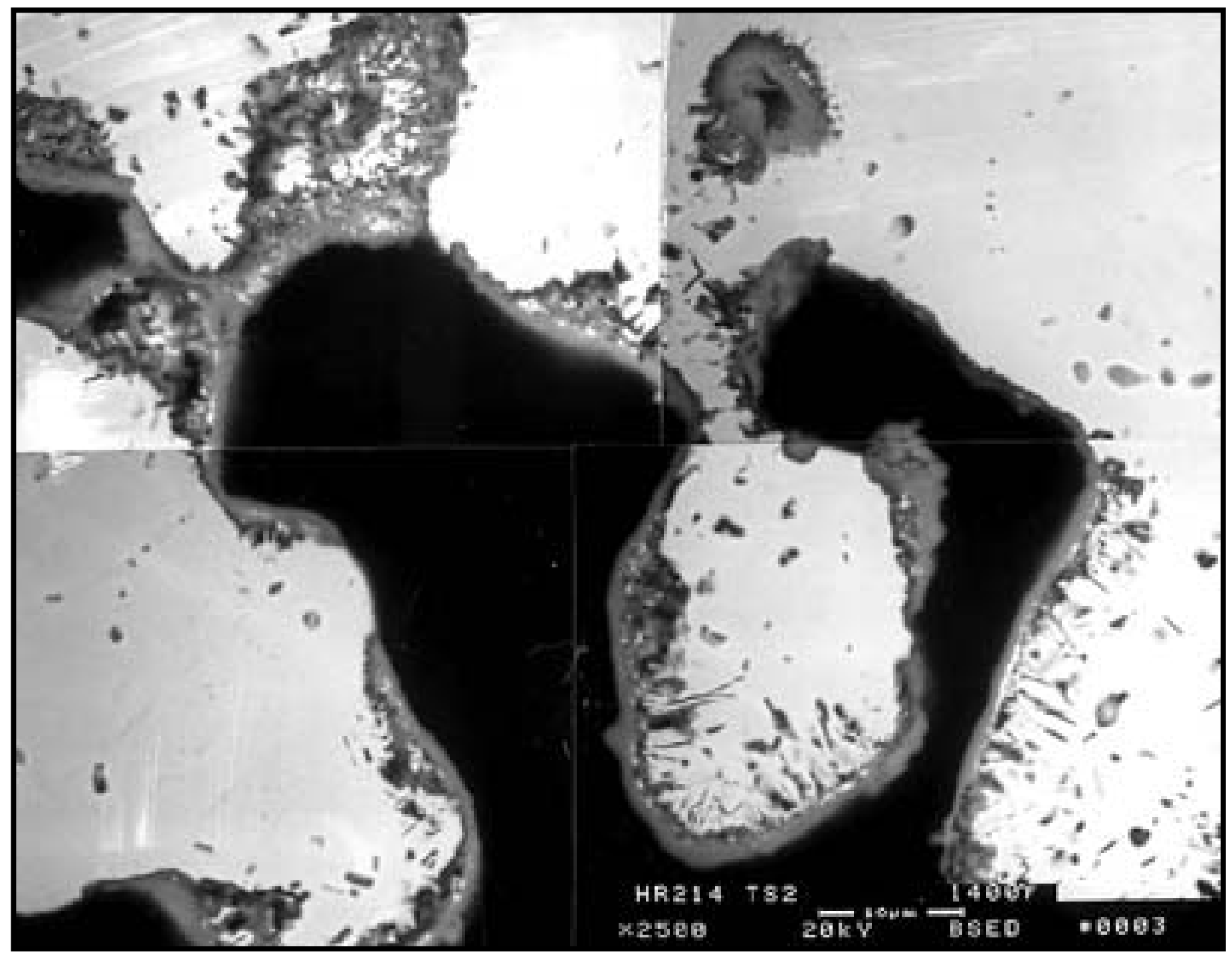

Figure 20 - Micrograph montage illustrating the morphology of the $760^{\circ} \mathrm{C}\left(1400^{\circ} \mathrm{F}\right)$ USF Haynes 214 filtration media after 1016 hours of operation in the simulated PFBC process gas environment. 
Although the open porosity of the USF Haynes 214 filter matrix appeared to be retained after 259 hours of operation in the $815^{\circ} \mathrm{C}\left(1500^{\circ} \mathrm{F}\right)$ simulated $\mathrm{PFBC}$ process gas environment, internal oxidation and void formations within the sinter bonded fibers were evident. Separation of the $\sim 2.2-2.9 \mu \mathrm{m}$ thick surface oxide from the underlying base metal substrate was observed (Figure 21). The surface oxide consisted of an external nickel oxide layer, with subsurface layers of $\mathrm{O}-\mathrm{Cr}-\mathrm{Ni}$, and chromia.

After 476 hours of operation in the $815-840^{\circ} \mathrm{C}\left(1500-1550^{\circ} \mathrm{F}\right)$ simulated PFBC environment, the thickness of the external surface layer ranged between 5 and $10 \mu \mathrm{m}$. The oxide was identified to consist of an external $\mathrm{O}-\mathrm{Ni}(\mathrm{Fe})$ spinel, with underlying $\mathrm{O}-\mathrm{Ni}-\mathrm{Fe}-\mathrm{Cr}$, and chromiaenriched layers. In contrast, after 986 hours of operation in the $815-840^{\circ} \mathrm{C}\left(1500-1550^{\circ} \mathrm{F}\right)$ simulated PFBC environment, the thickness of the chromia-enriched external surface layer ranged between 3 and $8 \mu \mathrm{m}$. Pore closure within the Haynes 214 filtration media appeared to have occurred primarily as a result of the extensive oxidation that resulted after 986 hours of operation in the simulated PFBC process gas environment.

In the absence of gas phase sulfur in the $840^{\circ} \mathrm{C}\left(1550^{\circ} \mathrm{F}\right)$ simulated $\mathrm{PFBC}$ process gas environment, pore closure of the Haynes 214 filtration media, and complete oxidation through the cross-sectioned USF Haynes 214 fibers similarly resulted with extended exposure time (i.e., 1014 hours; Figure 22). The composition of the external surface oxide consisted of a chromia-enriched
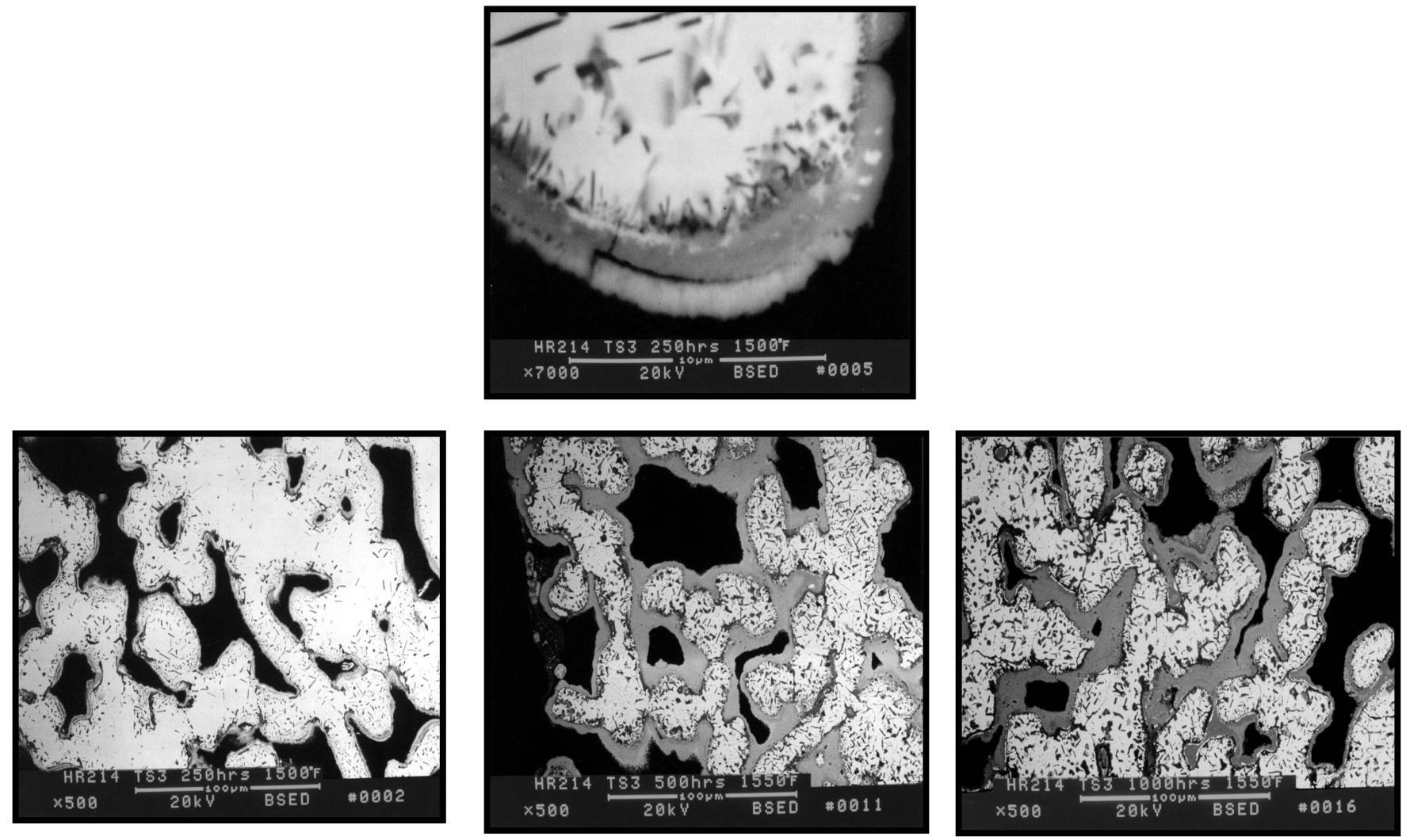

Figure 21 - Morphology of the USF Haynes 214 filtration media after operation in the $815-840^{\circ} \mathrm{C}$ $\left(1500-1550^{\circ} \mathrm{F}\right)$ simulated $\mathrm{PFBC}$ process gas environment. 
layer after 253 hours, an external nickel oxide with an O-Cr-Ni subsurface layer after 546.5 hours, and an $\mathrm{O}-\mathrm{Cr}(\mathrm{Ni}-\mathrm{Fe})$ external surface with a subsurface $\mathrm{O}-\mathrm{Ni}-\mathrm{Cr}-\mathrm{Fe}$ formation after 1014 hours of simulated PFBC operation.
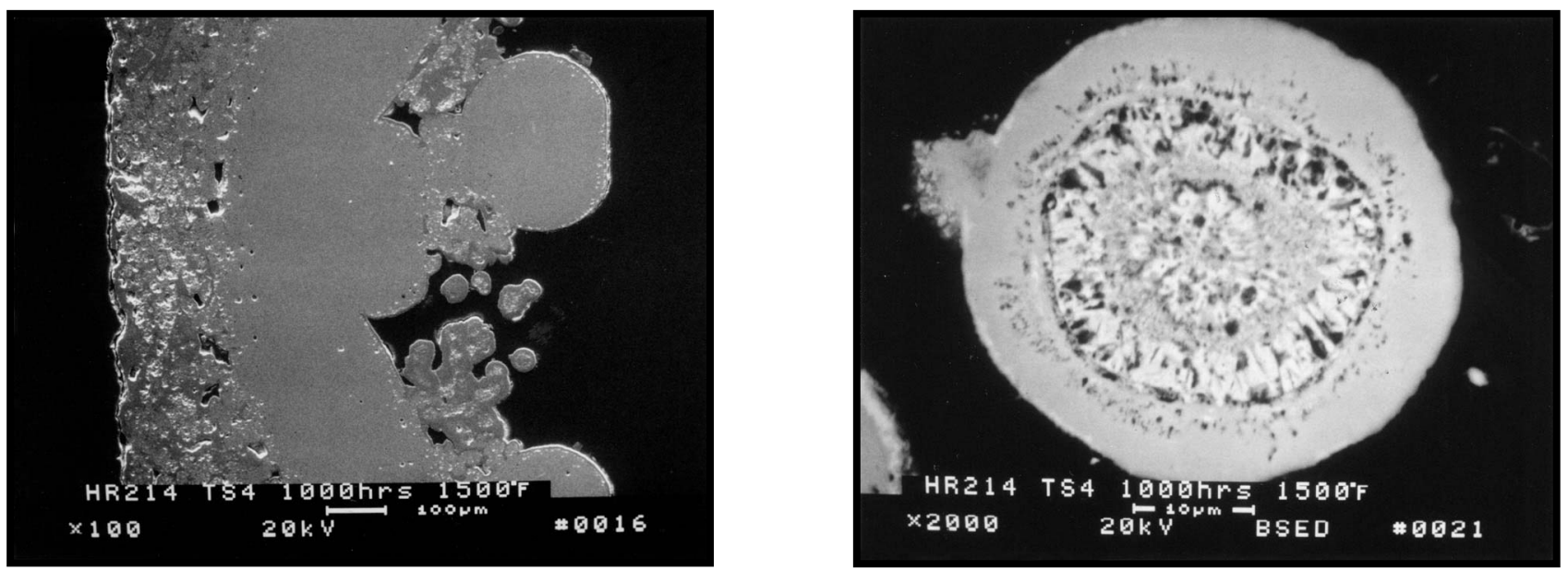

Figure 22 - Morphology of the USF Haynes 214 filtration media after 1014 hours of operation in the $840^{\circ} \mathrm{C}\left(1550^{\circ} \mathrm{F}\right)$, sulfur-free, simulated PFBC process gas environment.

\subsubsection{Impact of Gas Phase Alkali}

Extensive oxidation of the sinter bonded Haynes 214 fibers resulted during operation of the USF filtration media in the $815^{\circ} \mathrm{C}\left(1550^{\circ} \mathrm{F}\right)$ simulated PFBC process gas environment that contained gas phase sulfur and alkali. Pore closure within the Haynes 214 filtration media resulted, leading to restriction of gas flow through the filter wall. As shown in Figure 23, complete oxidation through the entire cross-sectioned Haynes 214 fibers resulted after 496 hours of operation.

An 7-10 $\mu \mathrm{m}$ thick oxide layer was identified to have formed along the outer surface of discrete Haynes 214 fibers after 225 hours of operation in the $840^{\circ} \mathrm{C}\left(1550^{\circ} \mathrm{F}\right)$, simulated $\mathrm{PFBC}$ operating environment. The composition of the oxide layer that formed along the surface of the Haynes 214 fibers consisted of an external O-Cr-Ni-Fe layer, with underlying subsurface chromia and O-Ni-Fe-Cr layers, and a S-Cr-enriched phase at the oxide/base metal interface. After 496 hours, the oxide consisted of an external nickel oxide layer, with $\mathrm{O}-\mathrm{Fe}-\mathrm{Ni}$ and $\mathrm{O}-\mathrm{Cr}(\mathrm{Ni})$-enriched subsurface layers.

Surface oxidation of the embedded, structural support, Hastelloy $\mathrm{X}$ mesh resulted in the formation of an $\sim 2 \mu \mathrm{m}$ thick oxide after 225 hours of operation in the $840^{\circ} \mathrm{C}\left(1550^{\circ} \mathrm{F}\right)$ simulated PFBC process gas environment that contained gas phase alkali and sulfur. The composition of the oxide layer included an external $\mathrm{O}-\mathrm{Cr}(\mathrm{Ni})$ layer, and an underlying chromia-enriched subsurface layer. After 496 hours of operation in the $840^{\circ} \mathrm{C}\left(1550^{\circ} \mathrm{F}\right)$ process gas environment, an O-Fe$\mathrm{Ni}(\mathrm{Cr})$-enriched external layer, and a chromia-enriched subsurface layer formed along the surface of the cross-sectioned Hastelloy X mesh. 

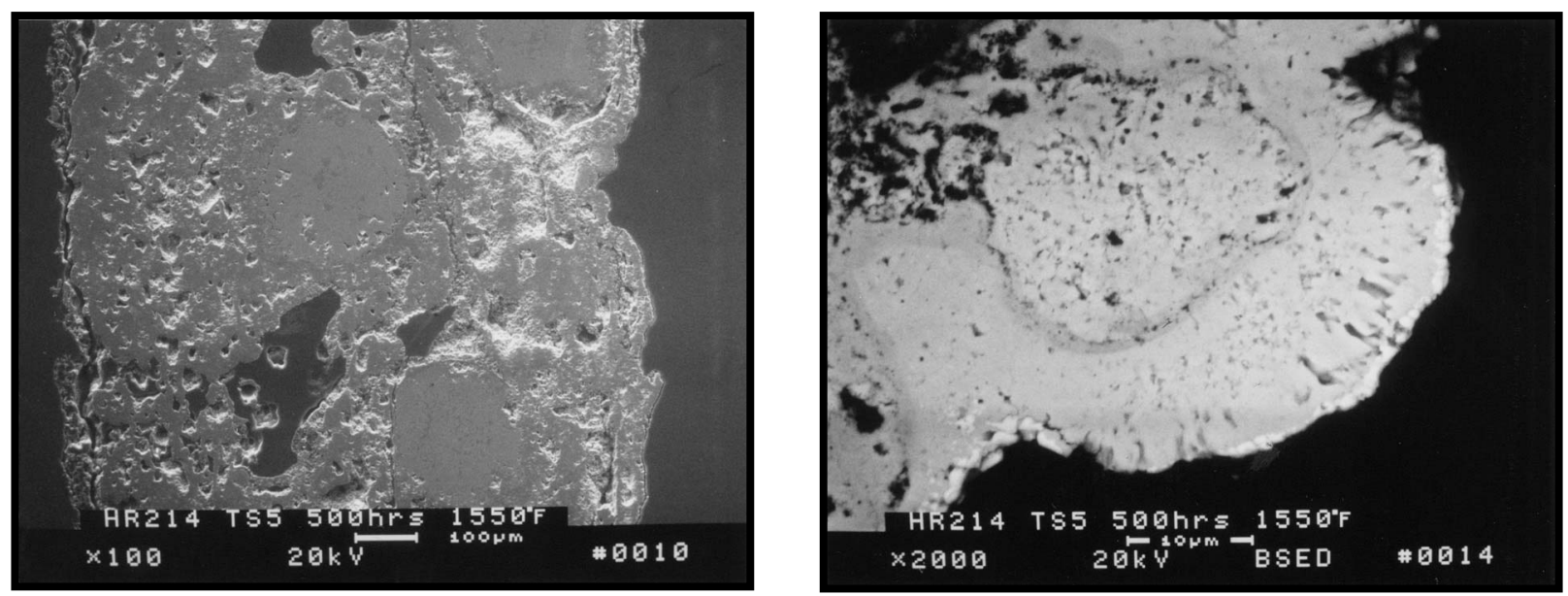

Figure 23 - Morphology of the extensively oxidized USF Haynes 214 fibers after 496 hours of operation in the $840^{\circ} \mathrm{C}\left(1550^{\circ} \mathrm{F}\right)$ simulated PFBC process gas environment that contained gas phase sulfur and alkali.

\subsection{USF Haynes 188 - Co Bal; 21-23\% Cr, 20-24\% Ni, 13-15\% W, 3\% Fe, 0.05- 0.15\% C, 0.2-0.5\% Si, 1.25\% Mn, 0.03-0.12\% La, 0.015\% B}

\subsubsection{Simulated PFBC Operation}

The open porosity of the USF Haynes 188 filter media was retained throughout the filter wall after 242 and 500 hours of exposure in the $650^{\circ} \mathrm{C}\left(1200^{\circ} \mathrm{F}\right)$ simulated PFBC environment (Figure 24). Oxidation of the USF Haynes 188 fibers, however, resulted. Typically two distinct oxide layers were observed along the surface of each material. An $\sim 1-1.6 \mu \mathrm{m}$ thick oxide-enriched layer formed along the surface of the cobalt-based USF Haynes 188 fibers after 242 hours of exposure in the $650^{\circ} \mathrm{C}\left(1200^{\circ} \mathrm{F}\right)$ simulated PFBC operating environment. The external oxide surface was enriched with either cobalt oxide or cobalt chromate, while generally an underlying chromia-enriched layer was formed adjacent to the residual base metal. With extended exposure to the $650^{\circ} \mathrm{C}\left(1200^{\circ} \mathrm{F}\right)$ simulated PFBC operating conditions, the thickness of the USF Haynes 188 surface oxide layer increased, ranging between $\sim 1.3-2.3 \mu \mathrm{m}$. Varying with location, the composition of the external surface of the multi-layered oxide consisted of a cobalt chromate or a chromium-iron-oxide-enriched phase. The underlying oxide layer was determined to consist principally of chromia.

Pit and void formations were evident along the periphery of the USF Haynes 188 fibers, as well as along the sinter bond that resulted between adjacent fibers, after 242-500 hours of operation of the filter media in the $650^{\circ} \mathrm{C}\left(1200^{\circ} \mathrm{F}\right)$ simulated $\mathrm{PFBC}$ process gas environment. Crack formations were frequently evident through the discrete external oxide layer that formed along the surface of the USF Haynes 188 fibers. In localized areas, removal of the external oxide layer resulted, leading to discontinuities and exposure of the subsurface oxide scale. Particularly along the o.d. surface of the filter element, debonding of the multi-layered oxide from the USF Haynes 188 base metal substrate was observed. Along the depleted or affected zone of the base metal, 

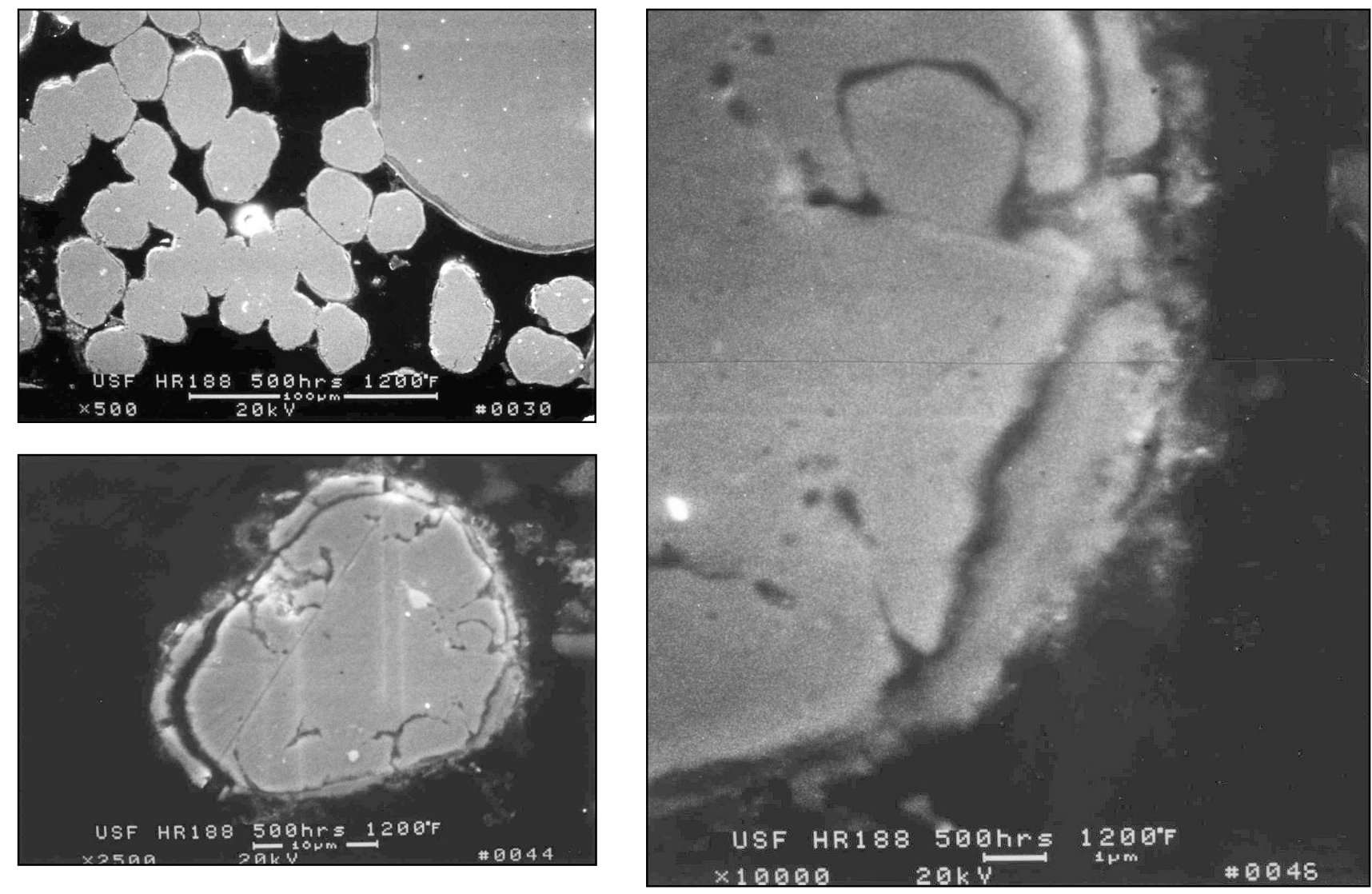

Figure 24 - Morphology of the USF Haynes 188 filtration media after 500 hours of operation in the $650^{\circ} \mathrm{C}\left(1200^{\circ} \mathrm{F}\right)$ simulated $\mathrm{PFBC}$ process gas environment.

oxide formations intermittently penetrated to depths of $\sim 2-6 \mu \mathrm{m}$ into the surface of the Haynes 188 fibers.

After $258-1016$ hours of operation in the $760^{\circ} \mathrm{C}\left(1400^{\circ} \mathrm{F}\right)$ simulated $\mathrm{PFBC}$ process gas environment, limited oxidation of the porous USF Haynes 188 metal media resulted. The open porosity throughout the filter wall was retained, thus permitting gas flow through the porous filter media.

The thickness of the oxide ranged between $\sim 2.4$ to $\sim 8 \mu \mathrm{m}$ (Figure 25). After 258 hours of operation, an external O-Fe-Co-Cr spinel formed. After 524.5 hours, an external O-Co layer formed, with an underlying subsurface $\mathrm{O}-\mathrm{Cr}(\mathrm{Co})$ formation. After 1016 hours, the composition of the external surface oxide was determined to include $\mathrm{O}-\mathrm{Co}(\mathrm{Ni}-\mathrm{Cr})$, with the formation of a subsurface O-Cr-Co layer. Under all conditions, a chromia-enriched layer resulted at the base metal substrate interface.

Crack formations through the USF Haynes 188 external oxide layer, separation and/or removal of the oxide from the underlying base metal substrate, internal oxidation within the USF Haynes 188 fiber penetrating along grain boundaries to depths of $\sim 4 \mu \mathrm{m}$ into the base metal, and oxidation along the sinter bonds between adjacent Haynes 188 fibers were observed during operation of the USF filtration media in the $760^{\circ} \mathrm{C}\left(1400^{\circ} \mathrm{F}\right)$ simulated $\mathrm{PFBC}$ process gas environment. 

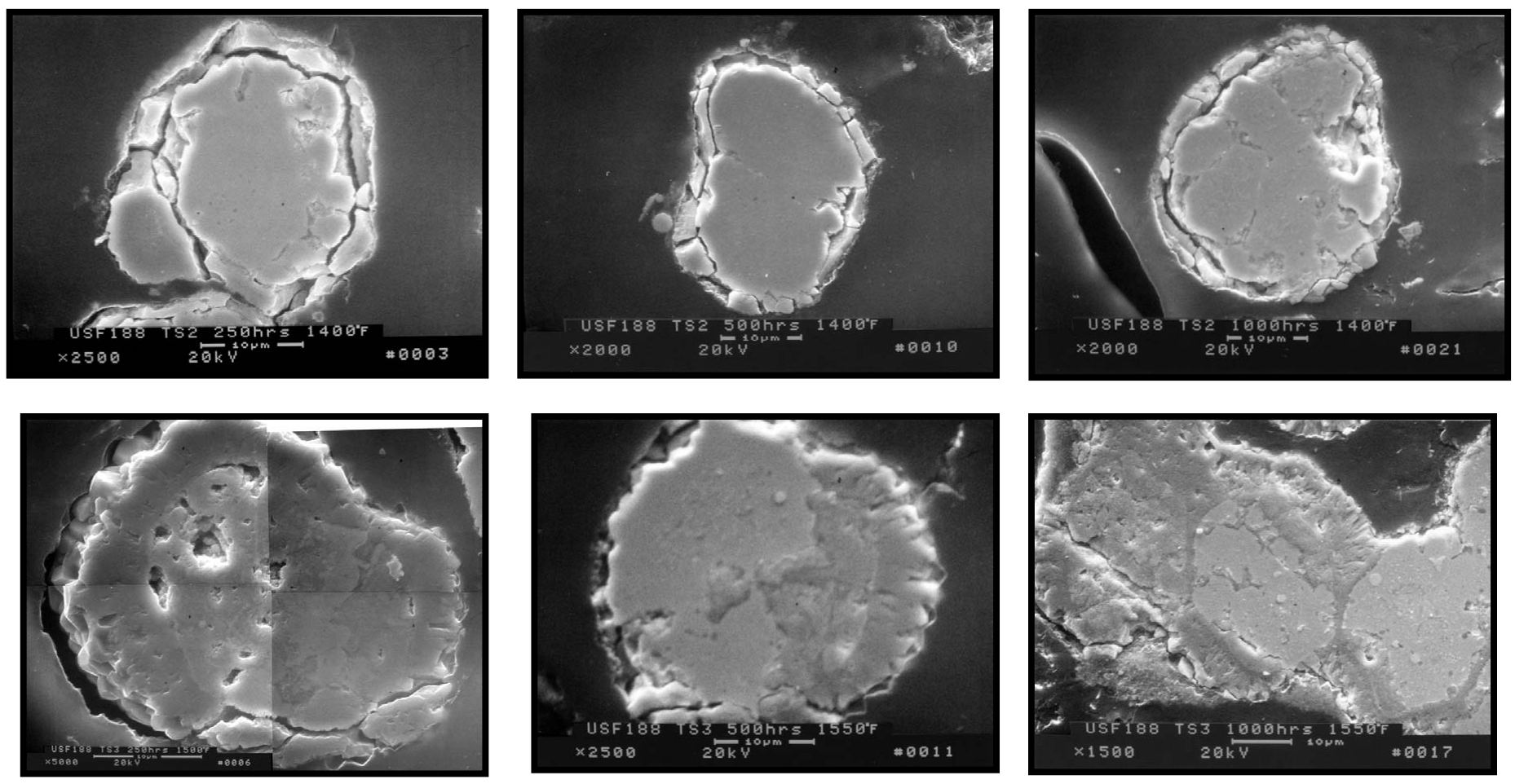

Figure 25 - Impact of PFBC operating temperature and time on the morphology of the USF Haynes 188 filtration media.

External and internal surface oxidation resulted along and within the sinter bonded USF Haynes 188 fibers after $259-986$ hours of operation in the $815-840^{\circ} \mathrm{C}\left(1500-1550^{\circ} \mathrm{F}\right)$ simulated PFBC process gas environment. Void formations within the base metal media and oxidation along the grain boundaries contained within the USF Haynes 188 fibers were observed. The thickness of the oxide layer that formed along the outer surface of the USF Haynes 188 fibers ranged from $\sim 4 \mu \mathrm{m}$ to $7 \mu \mathrm{m}$. The external surface oxide layer consisted of $\mathrm{O}-\mathrm{Cr}-\mathrm{Co}(\mathrm{Fe})$. An $\mathrm{O}-\mathrm{Cr}-\mathrm{Co}$-enriched subsurface layer was also detected. Within the internally oxidized areas of the USF Haynes 188 fibers, chromia-enrichment was identified.

Oxidation of the USF Haynes 188 fibers resulted after 253-1014 hours of operation in the $840^{\circ} \mathrm{C}\left(1550^{\circ} \mathrm{F}\right)$ simulated PFBC process gas environment that did not contain gas phase sulfur. The thickness of the oxide ranged between $\sim 2-4 \mu \mathrm{m}$. With time, the extent of oxidation tended to increase (i.e., $\geq 546.5$ hours) within the interior of the cross-sectioned Haynes 188 fibers (Figure 26). Oxidation resulted along the grain boundaries, penetrating to depths of $\sim 6 \mu \mathrm{m}$. The external surface oxide consisted primarily of chromia.

Cracks were typically observed through the external surface of the oxide layer after 253 hours of operation in the $840^{\circ} \mathrm{C}\left(1550^{\circ} \mathrm{F}\right)$ simulated $\mathrm{PFBC}$ process gas environment. Sections of the oxide were also seen to have been removed from the base metal substrate. Where sinter bonded fibers were adjacent to each other, an O-Ni-Co-Cr-Fe layer formed along the external surface of the fiber. An underlying chromia-enriched layer was also present. 

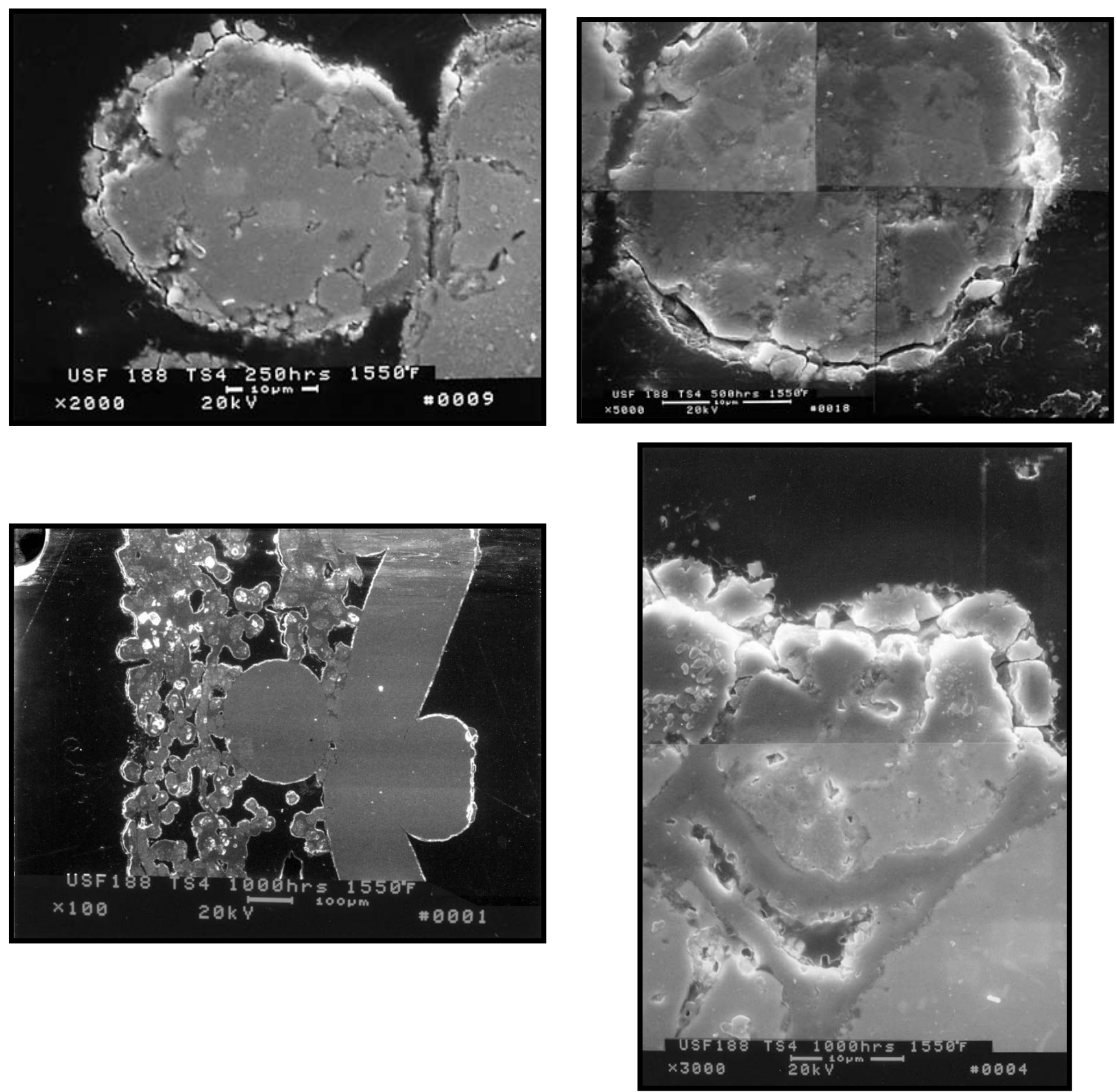

Figure 26 - Micrographs illustrating extensive external and internal oxidation that resulted along the surface and throughout the $840^{\circ} \mathrm{C}\left(1550^{\circ} \mathrm{F}\right)$, sulfur-free, simulated PFBC-exposed, USF Haynes 188 filtration media.

\subsubsection{Impact of Gas Phase Alkali}

Extensive oxidation was observed in localized area of the USF Haynes 188 filtration media after $225-496$ hours of operation in the $840^{\circ} \mathrm{C}\left(1550^{\circ} \mathrm{F}\right)$ simulated $\mathrm{PFBC}$ process gas environment that contained gas phase sulfur and alkali (Figure 27). An encapsulating oxide layer appeared to 
have resulted along the o.d. surface of the USF Haynes 188 filter element section. The resulting oxide layer was identified by EDX analysis to be primarily nickel oxide enriched with cobalt.

Although oxidation of the USF Haynes 188 fibers resulted, extensive sections of the external surface oxide layer were removed after 225 hours of operation in the $840^{\circ} \mathrm{C}\left(1550^{\circ} \mathrm{F}\right)$ simulated PFBC process gas environment (Figure 28). Where present, the external surface oxide was $\sim 2.4 \mu \mathrm{m}$ thick, and consisted primarily of chromia.

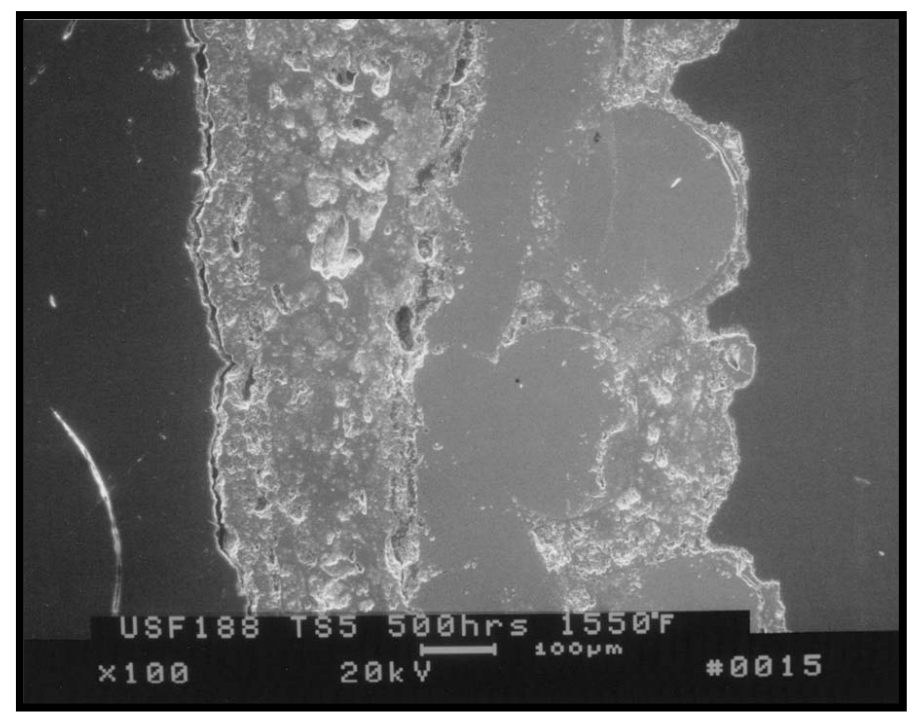

Figure 27 - USF Haynes 188 filtration media after operation in the $840^{\circ} \mathrm{C}\left(1550^{\circ} \mathrm{F}\right)$ simulated PFBC process gas environment containing gas phase sulfur and alkali.

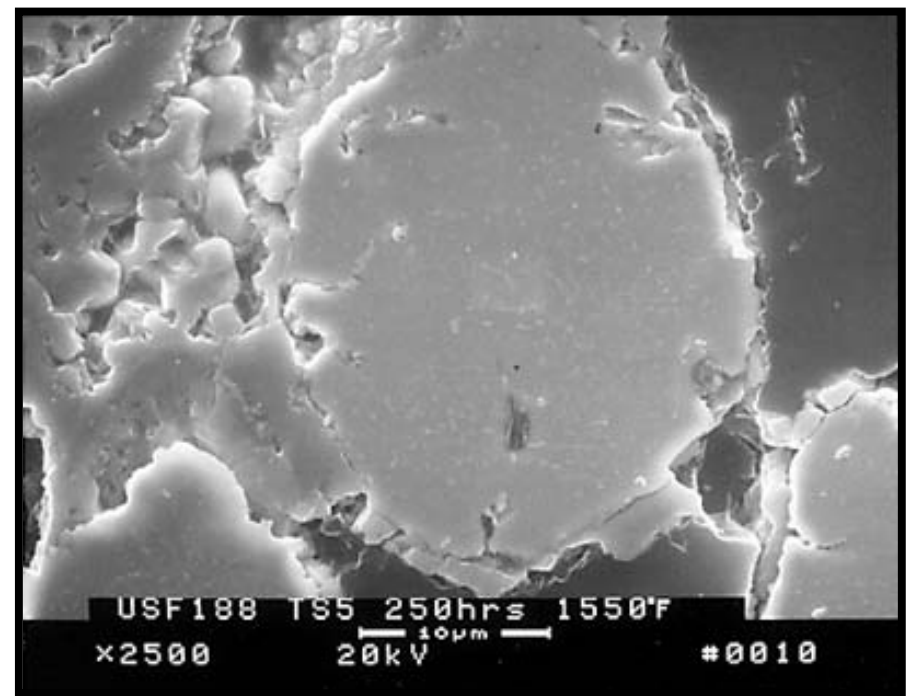

Figure 28 - Extensive oxidation, as well as removal of the oxide formation along the external surface of the USF Haynes 188 fibers after 225 hours of operation in the $840^{\circ} \mathrm{C}$ $\left(1550^{\circ} \mathrm{F}\right)$, gas phase sulfur and alkali-containing, simulated PFBC process gas environment. 


\subsection{USF Haynes 556 - Fe Bal; $22 \% \mathrm{Cr}, 20 \% \mathrm{Ni}, 18 \% \mathrm{Co}, 2.5 \% \mathrm{~W}, 0.1 \% \mathrm{C}, 0.02 \% \mathrm{La}$, 3\% Mo, $0.02 \% \mathrm{Zr}, 0.6 \% \mathrm{Ta}$}

\subsubsection{Simulated PFBC Operation}

Voids were seen to be present not only along the sinter bonds that formed between adjacent fibers in the as-manufactured USF Haynes 556 filter matrix, but were also present along the periphery of the individual USF Haynes 556 fibers. Similar void formations were evident after exposure of the USF Haynes 556 filtration media to 242 and 500 hours of operation under $650^{\circ} \mathrm{C}$ $\left(1200^{\circ} \mathrm{F}\right)$ simulated $\mathrm{PFBC}$ process conditions.

Although the relative open porosity was retained within the USF Haynes 556 filtration media after 242 and 500 hours of operation under the $650^{\circ} \mathrm{C}\left(1200^{\circ} \mathrm{F}\right)$ simulated PFBC process conditions, surface oxidation of the Haynes 556 fibers resulted. An $\sim 1-6 \mu \mathrm{m}$ thick iron-chromiumor iron-enriched surface oxide was formed along the periphery of the Haynes 556 fibers after 242 hours of simulated PFBC operation (Figure 29). With extended exposure, an $\sim 1 \mu \mathrm{m}$ chromiaenriched layer developed between the external oxide scale and the base metal substrate. The thickness of the multi-layered oxide ranged between $\sim 1-10 \mu \mathrm{m}$ along the surface of the Haynes 556 fibers after 500 hours of operation.
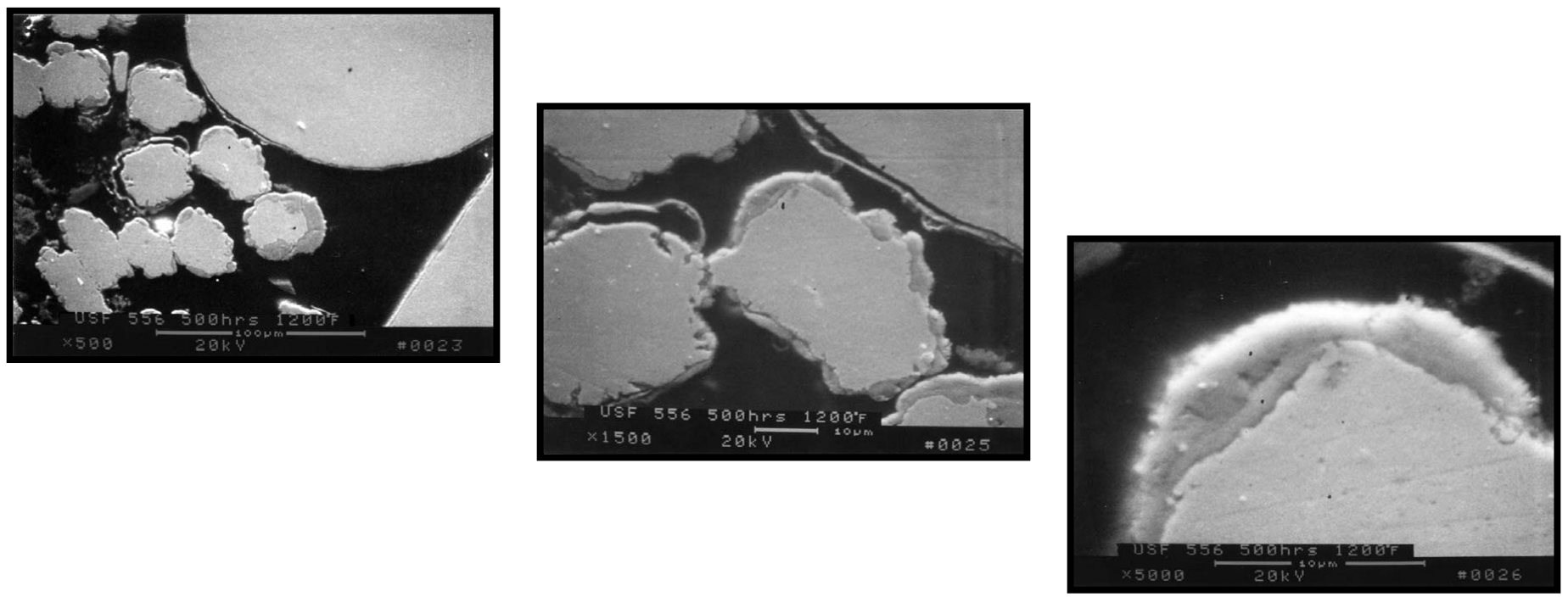

Figure 29 - Morphology of the USF Haynes 556 filtration media after operation in the $650^{\circ} \mathrm{C}$ $\left(1200^{\circ} \mathrm{F}\right)$ simulated $\mathrm{PFBC}$ process gas environment.

Extensive external oxidation resulted along the outer surface of the sinter bonded USF Haynes 556 fibers after $258-1016$ hours of operation in the $760^{\circ} \mathrm{C}\left(1400^{\circ} \mathrm{F}\right)$ simulated $\mathrm{PFBC}$ process gas environment. The thickness of the external surface oxide appeared to increase with extended operating time:

- Filtration o.d. surface: 4.6-6.6 $\mu \mathrm{m}$ after 258 hours; $~ 7.5-10 \mu \mathrm{m}$ after 524.5 hours; $\sim 8.5-12.5 \mu \mathrm{m}$ after 1016 hours.

- Filtration i.d. surface: $\sim 6-10 \mu \mathrm{m}$ after 258 hours; $~ 10-11.5 \mu \mathrm{m}$ after 524.4 hours. 
Cracks within the external surface oxide formation, and separation of the external oxide layers were observed.

The composition of the external surface oxide consisted of $\mathrm{O}-\mathrm{Fe}(\mathrm{Co}-\mathrm{Ni})$, with underlying subsurface chromia-enriched layers. With time, the concentration of Co-Ni increased within the iron oxide-enriched outer surface layer. Low concentrations of sulfur were identified within the chromia-enriched layers, particularly along the oxide/base metal interface, as well as within the internal oxide formations that resulted along the cross-sectioned surface of the 258 hour, $760^{\circ} \mathrm{C}$ $\left(1400^{\circ} \mathrm{F}\right)$, simulated PFBC-exposed, USF Haynes 556 fibers (Figure 30).
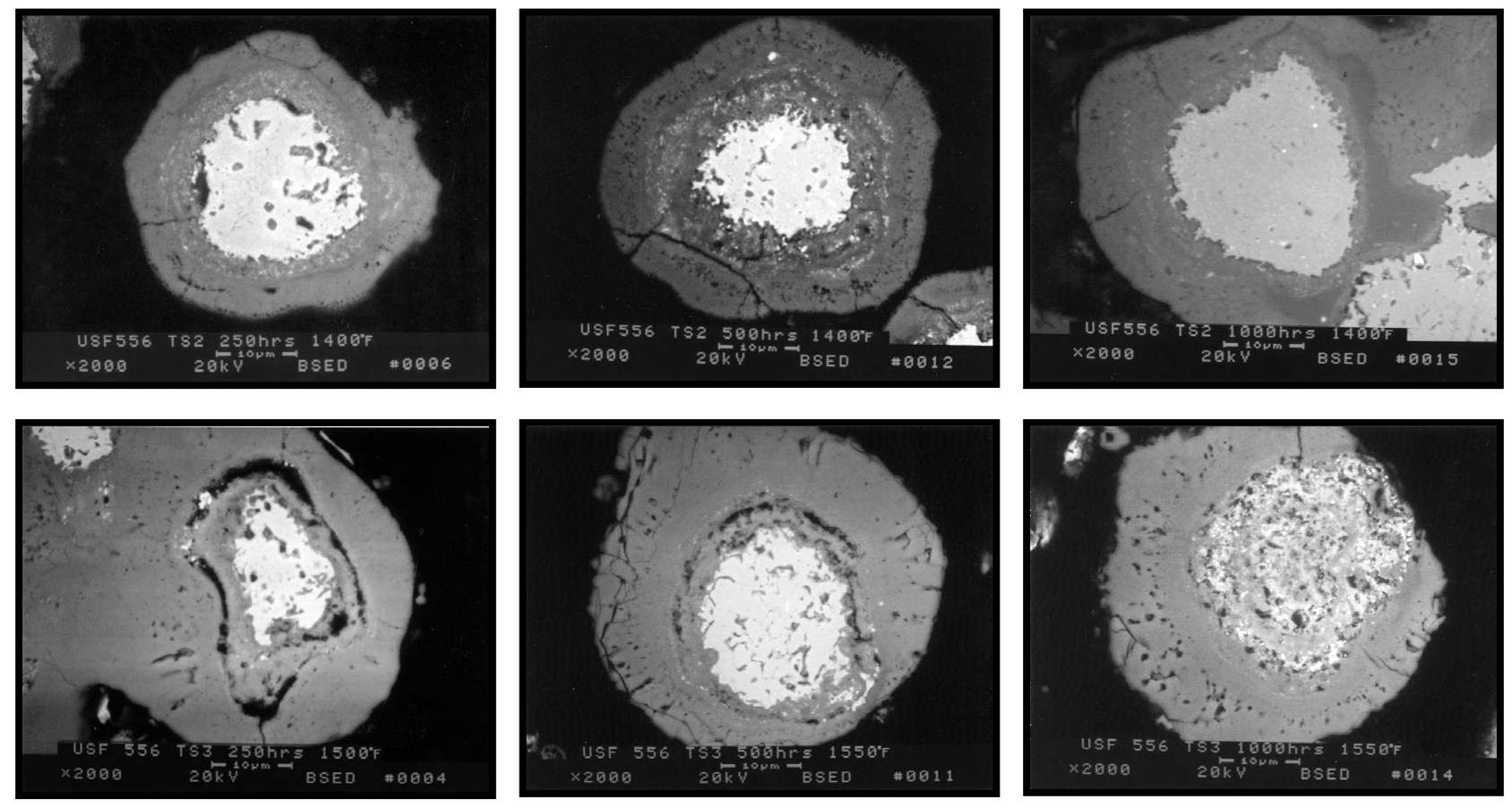

Figure 30 - Impact of PFBC operating temperature and time on the morphology of the USF Haynes 556 filtration media.

When the USF Haynes 556 filtration media experienced 259 hours of operation in the $815^{\circ} \mathrm{C}\left(1500^{\circ} \mathrm{F}\right)$ simulated PFBC process gas environment, extensive oxidation of the metal media fibers resulted, leading to pore closure and localized restriction of gas flow through the filtration media (Figure 30). After 986 hours of operation in the $815-840^{\circ} \mathrm{C}\left(1500-1550^{\circ} \mathrm{F}\right)$ simulated PFBC process gas environment, extensive external surface oxidation of Haynes 556 fibers, complete internal oxidation throughout the entire cross-section fibers, void formations and separation of the oxide from the residual base metal, and oxidation along the sinter bonds between adjacent Haynes 556 fibers were observed.

The thickness of the oxide layer that formed along the outer surface of discrete Haynes 556 fibers ranged between $\sim 6-14.8 \mu \mathrm{m}$. Spinels enriched with $\mathrm{O}-\mathrm{Fe}-\mathrm{Cr}(\mathrm{Ni}-\mathrm{Co})$ were the primary phases identified along the outer surface of the encapsulating oxide layer. Subsurface O-Cr-Co(Fe) and OCr-Co phases were identified. 
Extensive oxidation similarly resulted along the external surface, as well as within the interior of the $253-1014$ hour, $840^{\circ} \mathrm{C}\left(1550^{\circ} \mathrm{F}\right)$, sulfur-free, simulated PFBC-exposed, USF Haynes 556 fibers. Along the outer surface of discrete Haynes 556 fibers, the thickness of the oxide layer formation ranged between $\sim 8-16 \mu \mathrm{m}$. The composition of the oxide consisted primarily of an ironenriched, $\mathrm{Co}-\mathrm{Ni}$, or Ni-Cr spinel external surface layer, with subsurface chromia-enriched, Fe-Ni or Co-Ni spinels. Separation of the external oxide layer from subsurface oxides resulted along the O$\mathrm{Cr}-\mathrm{Ni}(\mathrm{Co})$ interface. Along the i.d. or pulse cycled surface of the filtration media, only the underlying chromia-enriched layer remained along the outer surface of the USF Haynes 556 fibers.

After 1014 hours of $840^{\circ} \mathrm{C}\left(1550^{\circ} \mathrm{F}\right)$, sulfur-free, simulated PFBC operation, concentric rings of oxide were seen to form along the outer surface of the cross-sectioned USF Haynes 556 fibers (Figure 31). Complete oxidation throughout the USF Haynes 556 fibers was clearly observed.

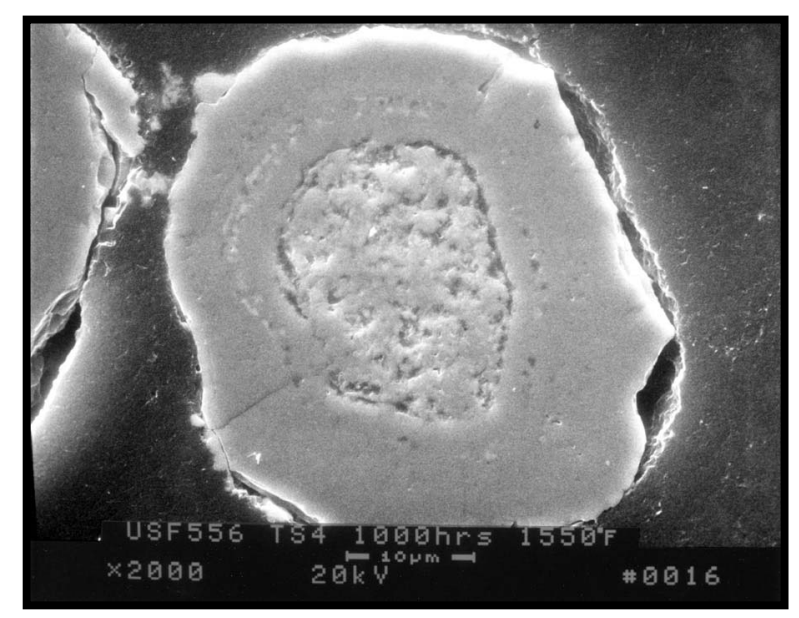

Figure 31 - Morphology of the USF Haynes 556 filtration media after 1014 hours of operation in the sulfur-free, $840^{\circ} \mathrm{C}\left(1550^{\circ} \mathrm{F}\right)$, simulated $\mathrm{PFBC}$ process gas environment.

\subsubsection{Impact of Gas Phase Alkali}

Extensive oxidation similarly resulted along the external surface, as well as within the interior of the cross-sectioned, sinter bonded, USF Haynes 556 fibers after 225-496 hours of operation in the $840^{\circ} \mathrm{C}\left(1550^{\circ} \mathrm{F}\right)$ simulated PFBC process gas environment that contained gas phase sulfur and alkali. Oxidation of the sinter bonds between adjacent Haynes 556 fibers also occurred. Although after 496 hours of operation the structural outline of the original USF Haynes 556 fibers was identifiable, complete oxidation of the USF Haynes 556 fibers resulted (Figure 32).

An $~ 8-13 \mu \mathrm{m}$ oxide layer formed along the outer surface of discrete USF Haynes 556 fibers after $225-496$ hours of operation in the $840^{\circ} \mathrm{C}\left(1550^{\circ} \mathrm{F}\right)$, gas phase sulfur and alkali-containing, simulated PFBC process gas environment. After 225 hours, an $\mathrm{O}-\mathrm{Fe}-\mathrm{Co}(\mathrm{Ni})$-enriched external surface oxide formed. After 496 hours of operation in the $840^{\circ} \mathrm{C}\left(1550^{\circ} \mathrm{F}\right)$ simulated $\mathrm{PFBC}$ environment containing gas phase sulfur and alkali, an O-Co-Cr-Fe external surface spinel formed. Chromia-enriched subsurface layers were generally present.

An amorphous sulfur-enriched phase (i.e., chrome sulfide) was identified within the crosssectioned Haynes 556 base metal after 496 hours of operation of the USF filtration media in the $840^{\circ} \mathrm{C}\left(1550^{\circ} \mathrm{F}\right)$, gas phase sulfur and alkali-containing, simulated PFBC process gas environment. 
Crack formations were seen to have formed within the external oxide that encapsulated the USF Haynes 556 fibers after 496 hours of operation. Separation of the external oxide layer from the residual base metal of the USF Haynes 556 fibers was also observed.
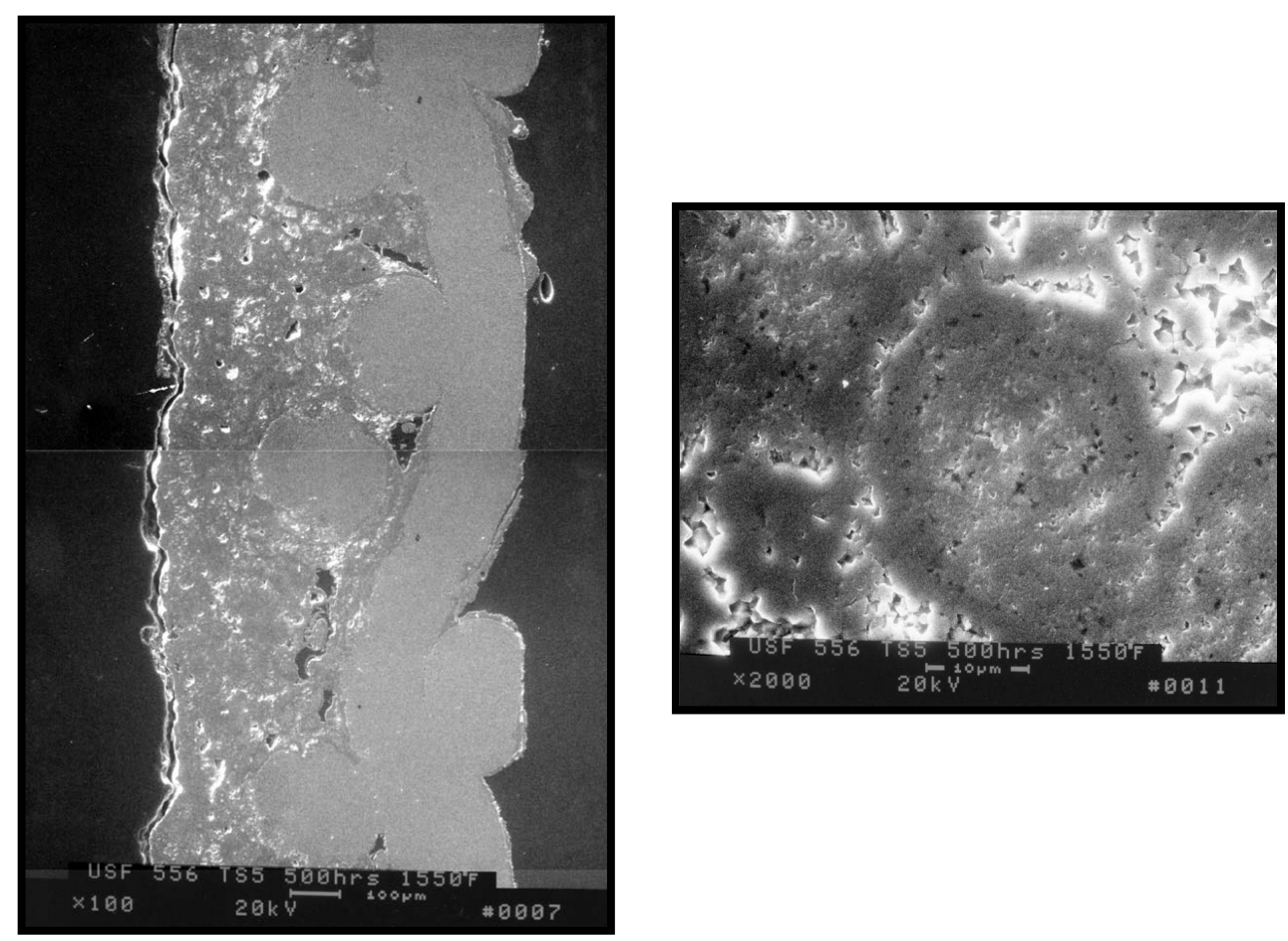

Figure 32 - Extensive oxidation of the USF Haynes 556 filtration media after operation in the $840^{\circ} \mathrm{C}\left(1550^{\circ} \mathrm{F}\right)$, gas phase sulfur and alkali-containing, simulated PFBC process gas environment.

\subsection{USF 310S - Fe Bal; $25 \% \mathrm{Cr}, 20.5 \% \mathrm{Ni}, 1.6 \% \mathrm{Mn}, \mathbf{0 . 7 5 \%} \mathrm{Mo}, 0.5 \% \mathrm{Si}, \mathbf{0 . 0 5 \%} \mathrm{C}$}

\subsubsection{Simulated PFBC Operation}

Exposure of the porous USF $310 \mathrm{~S}$ filter matrix at $650^{\circ} \mathrm{C}\left(1200^{\circ} \mathrm{F}\right)$ to the simulated PFBC process operating environment resulted in oxidation of the $310 \mathrm{~S}$ filtration mat fibers, leading to coalescence of adjacent fibers that ultimately limited the open porosity of the filtration mat layer (Figure 33). Along the surface of the USF 310 S fibers, an $\sim 1 \mu \mathrm{m}$ thick iron oxide external scale, and an $\sim 1 \mu \mathrm{m}$ subsurface oxide layer enriched with chromium, iron, and nickel formed after 242 hours of operation. The thickness of both external and subsurface oxides increased to $\sim 3-5 \mu \mathrm{m}$ after 500 hours of exposure. Typically cracks extending through the oxide scale formations were observed.

Extensive oxidation of the USF sinter bonded 310S fibers resulted after 258-1016 hours of operation in the $760^{\circ} \mathrm{C}\left(1400^{\circ} \mathrm{F}\right)$ simulated PFBC process gas environment (Figure 34). Typically internal oxidation within the sinter bonded 310S fibers was also observed. Localized crack 

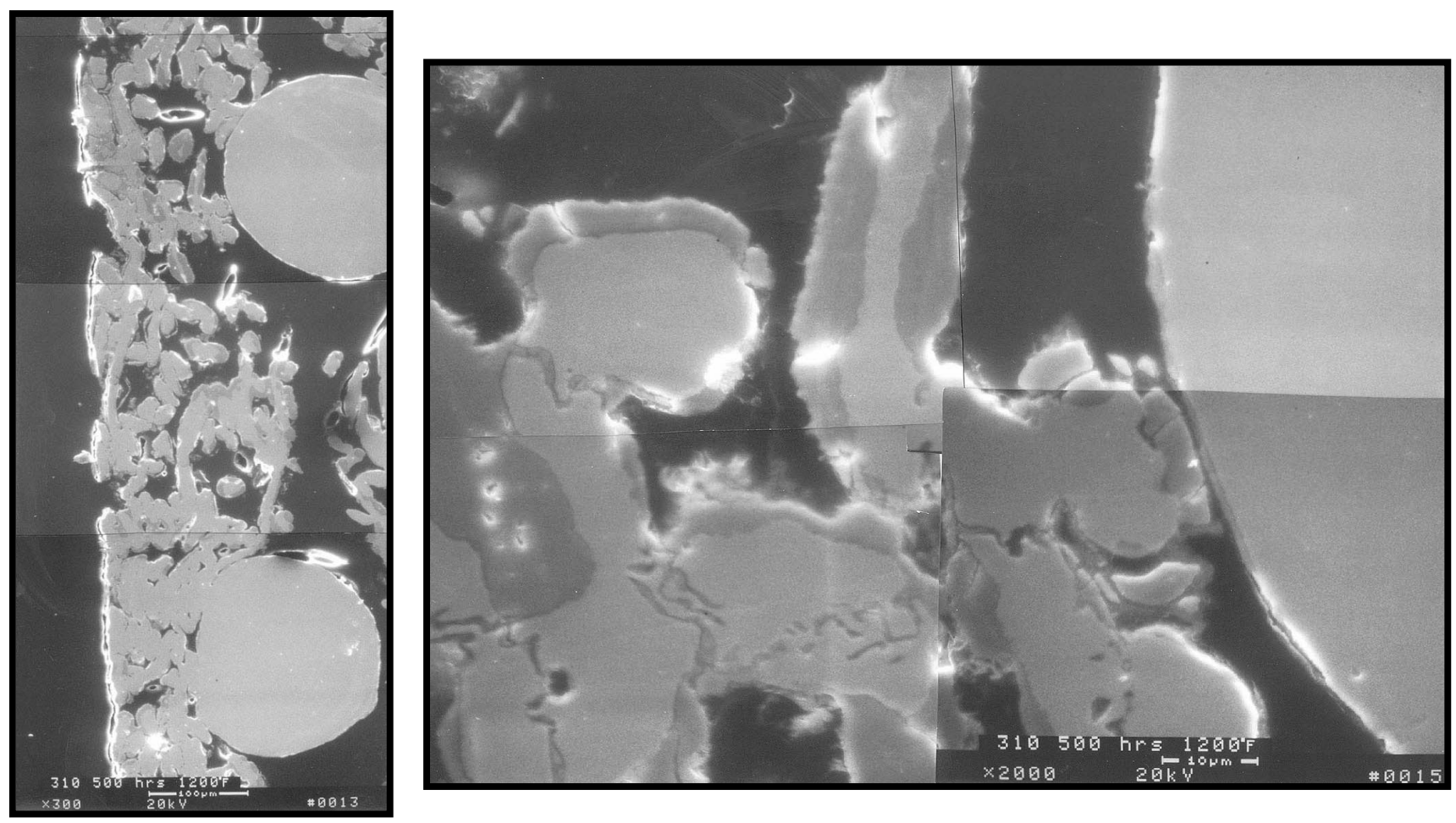

Figure 33 - Microstructure of the USF 310 S filtration media after operation in the $650^{\circ} \mathrm{C}\left(1200^{\circ} \mathrm{F}\right)$ simulated PFBC process gas environment.
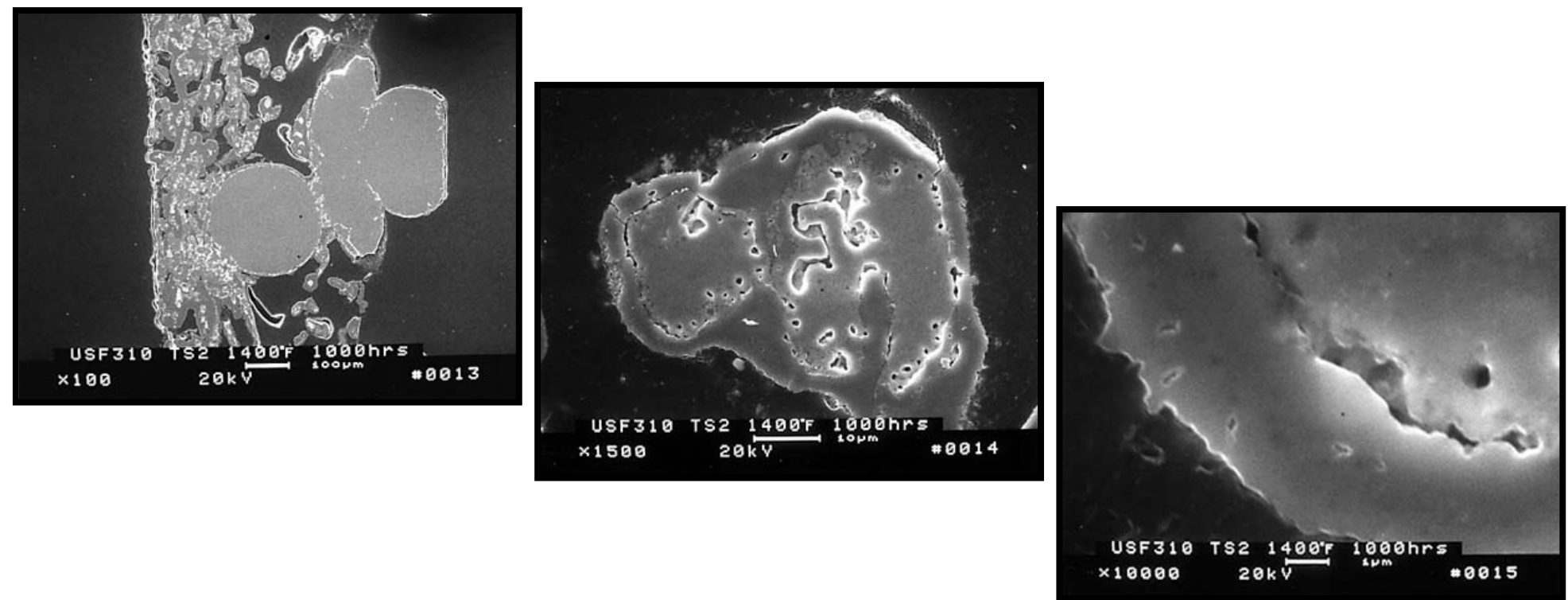

Figure 34 - Microstructure of the USF 310S filtration media after 1016 hours of operation in the $760^{\circ} \mathrm{C}\left(1400^{\circ} \mathrm{F}\right)$ simulated $\mathrm{PFBC}$ process gas environment. 
formations along the external surface oxide layer were also evident along the i.d. or pulse cycled surface of the filter element. Pore closure were observed in localized areas particularly along the outer surface of the USF $310 \mathrm{~S}$ filter wall after 1016 hours of operation in the $760^{\circ} \mathrm{C}\left(1400^{\circ} \mathrm{F}\right)$ simulated PFBC process gas environment.

The composition of the oxide layer that encapsulated the sinter bonded USF 310 S fibers consisted of an iron oxide/spinel-enriched external phase, with an underlying chromia-enriched phase formed at the base metal interface. The thickness of the oxide layer ranged from $\sim 3 \mu \mathrm{m}$ after 258 hours, to $\sim 6.6-13.3 \mu \mathrm{m}$ after 524.5 hours, to $\sim 3.5 \mu \mathrm{m}$ after 1016 hours along the outer surface of the sinter bonded $310 \mathrm{~S}$ fibers.

Extensive external and internal oxidation resulted along/within the USF sinter bonded 310S fibers after $259-986$ hours of operation in the $815-840^{\circ} \mathrm{C}\left(1500-1550^{\circ} \mathrm{F}\right)$ simulated $\mathrm{PFBC}$ process gas environment (Figure 35). Localized areas of pore closure were observed along the outer surface of the USF filter wall, particularly after 986 hours of operation. The composition of the oxide layer that encapsulated the 310S sinter bonded fibers consisted of an external iron-nickel spinel with an underlying chromia-enriched layer.
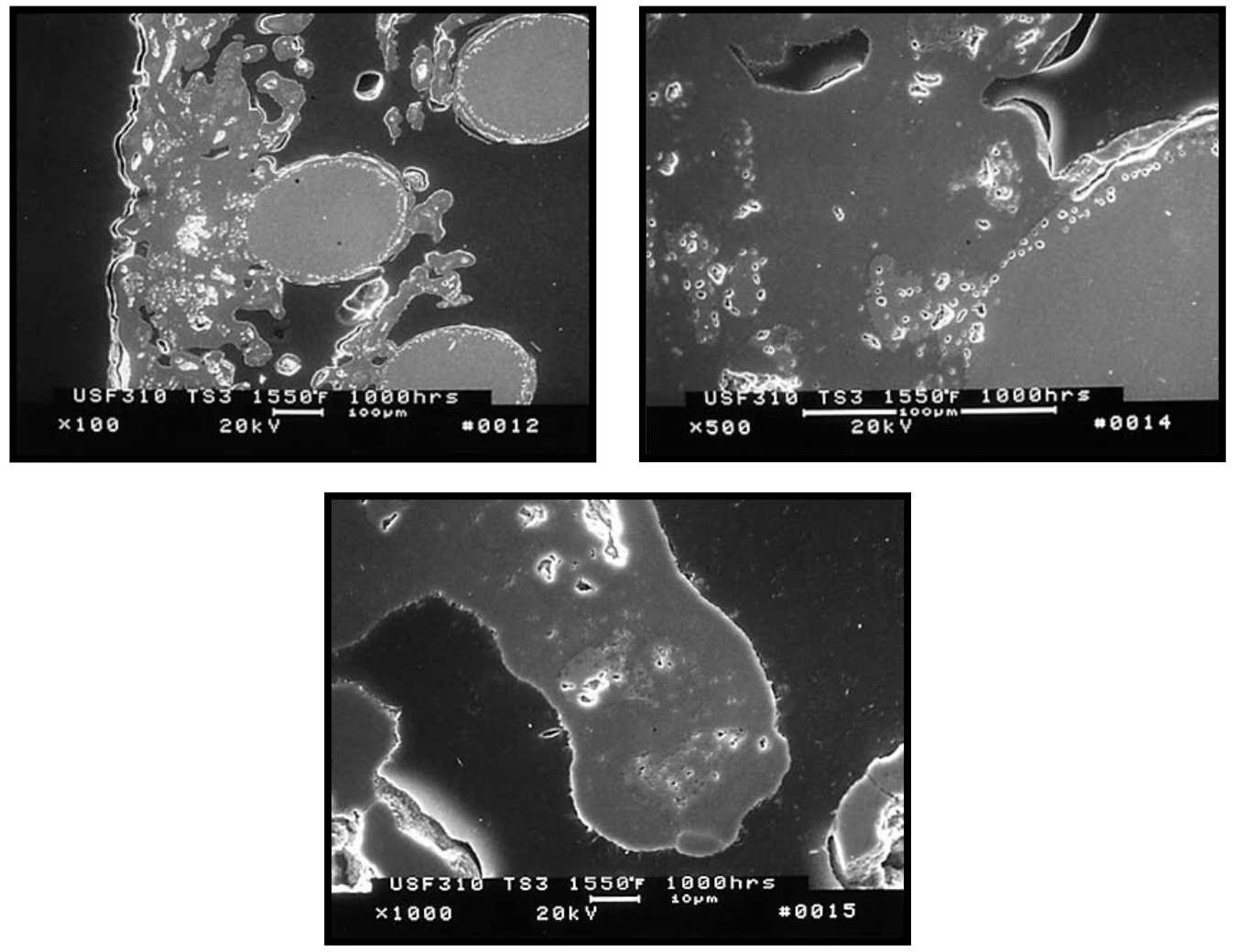

Figure 35 - Morphology of the cross-sectioned, 986 hour, $815-840^{\circ} \mathrm{C}\left(1500-1550^{\circ} \mathrm{F}\right)$, simulated PFBC-exposed, USF 310S filtration media.

In the absence of gas phase sulfur, extensive oxidation of the USF 310 S fibers resulted after 253-1014 hours of $840^{\circ} \mathrm{C}\left(1550^{\circ} \mathrm{F}\right)$ simulated PFBC operation (Figure 36). Pore closure of the originally porous filter media was observed, reducing gas flow permeability through the filter wall. 
The composition of the oxide layers that resulted along the sinter bonded USF 310S fibers initially consisted of an iron-nickel spinel that was enriched with chromium, and an underlying chromia-iron layer. With time, the composition of the oxide consisted of an external iron-chrome oxide layer, with underlying iron-chromium-nickel oxide, chromium-iron oxide, and nickel-ironchromium oxide layers.
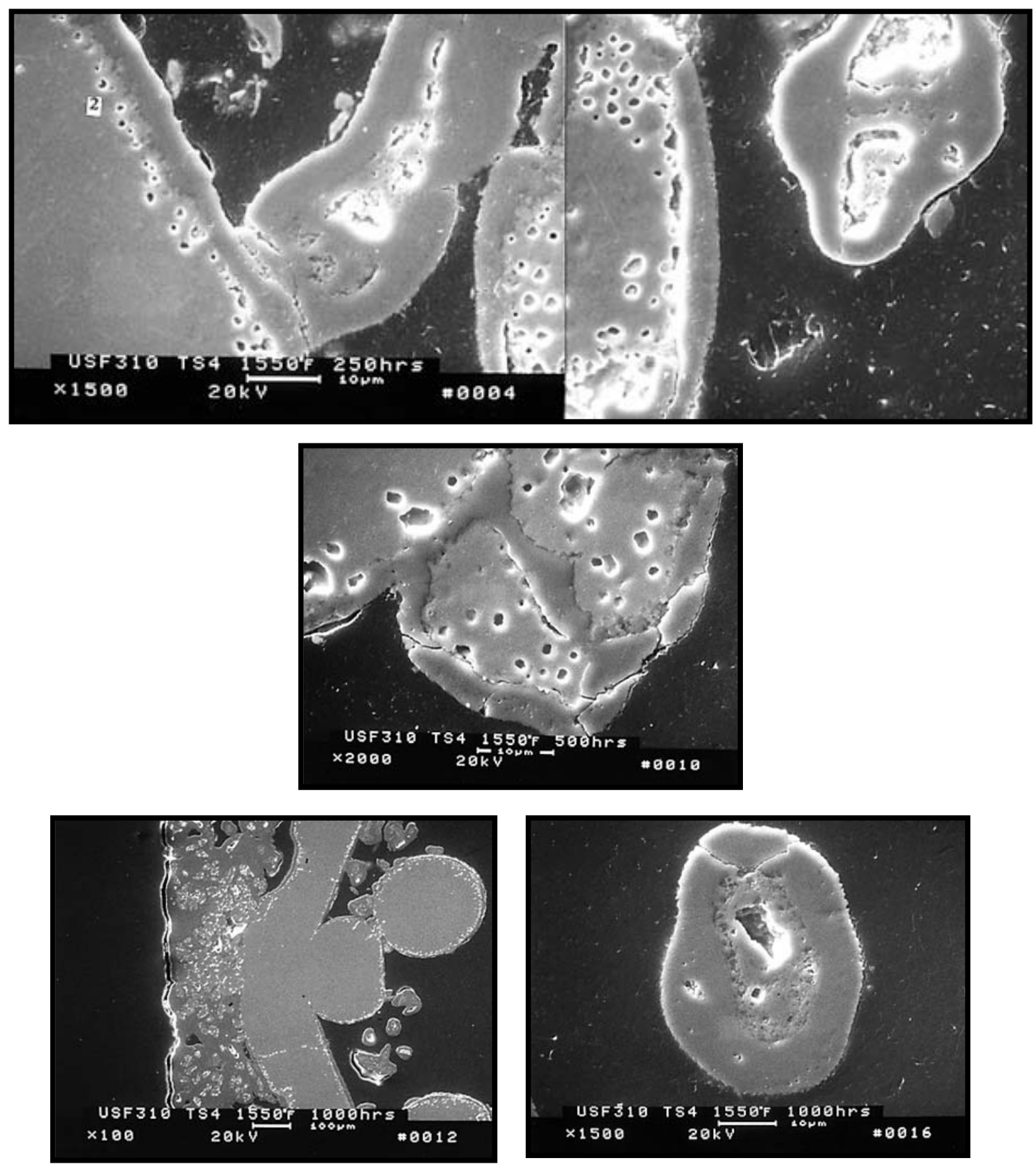

Figure 36 - Morphology of the USF 310S filtration media after operation in the sulfur-free, $840^{\circ} \mathrm{C}$ $\left(1550^{\circ} \mathrm{F}\right)$, simulated $\mathrm{PFBC}$ process gas environment. 


\subsubsection{Impact of Gas Phase Alkali}

Extensive external, as well as internal oxidation of the USF 310 S fibers resulted during $225-496$ hours of operation in the $840^{\circ} \mathrm{C}\left(1550^{\circ} \mathrm{F}\right)$ simulated $\mathrm{PFBC}$ process gas environment that contained gas phase sulfur and alkali (Figure 37). Pore closure of the filtration media was observed, restricting gas flow through the filter wall.

The composition of the oxide that resulted along the external surface of the USF $310 \mathrm{~S}$ particles consisted of an iron-nickel spinel, with underlying iron oxide and iron-nickel/chromiumenriched subsurface layers.

Along the i.d. or pulse cycled surface of the USF 310 S filtration media, crack formations were observed within the external oxide formation, between adjacent sinter bonded 310S particles, as well as along/within the oxide layer that encapsulated the Hastelloy X structural support mesh.
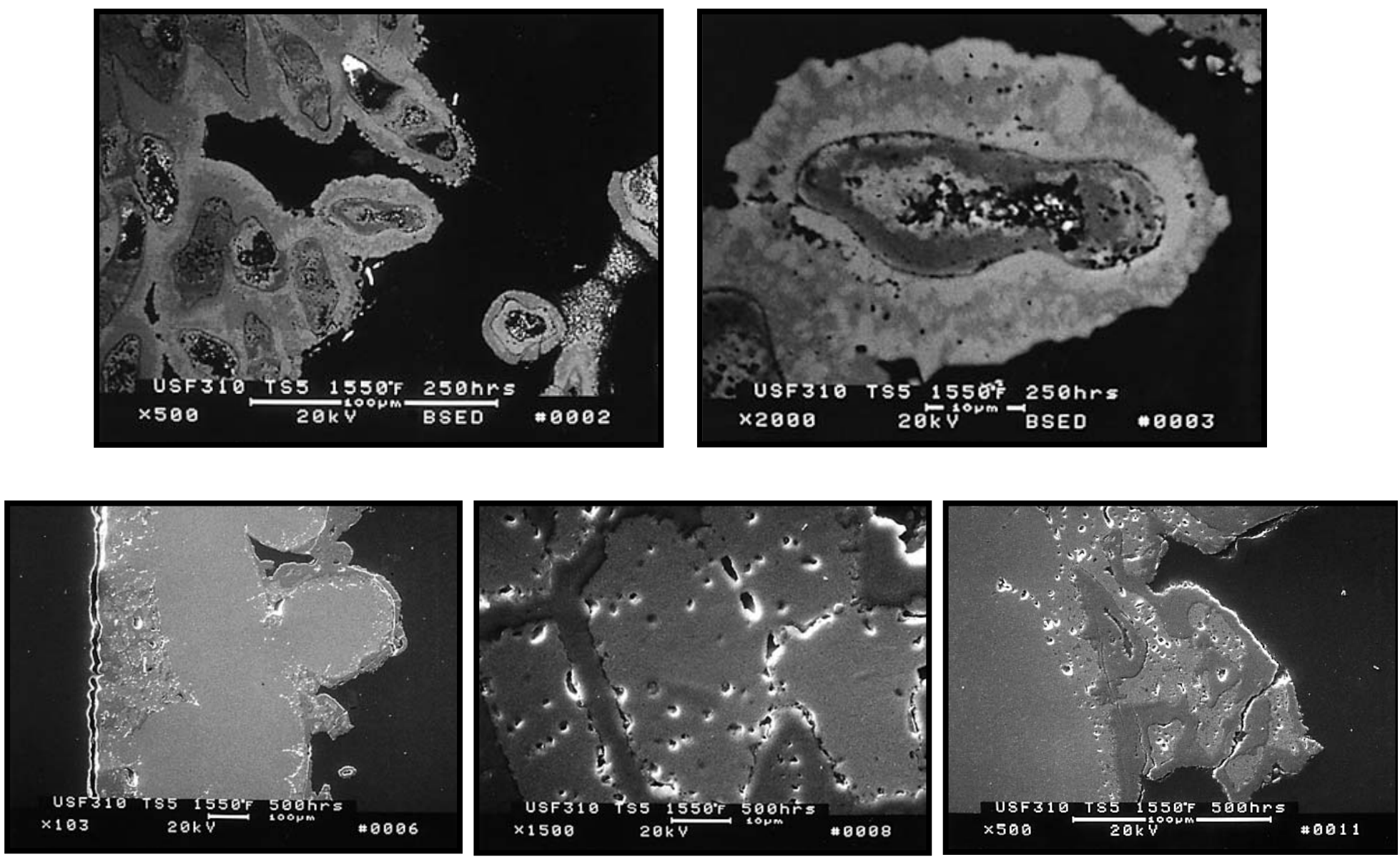

Figure 37 - Morphology of the USF $310 \mathrm{~S}$ filtration media after operation in the $840^{\circ} \mathrm{C}\left(1550^{\circ} \mathrm{F}\right)$ simulated PFBC process gas environment that contained gas phase sulfur and alkali. 


\subsubsection{Simulated PFBC Operation}

At $650^{\circ} \mathrm{C}\left(1200^{\circ} \mathrm{F}\right)$ under simulated PFBC process gas conditions, the Inconel 600 fibers in the USF filtration media underwent extensive oxidation forming an $\sim 8-11 \mu \mathrm{m}$ thick, multi-layered oxide scale along the outer surface of the fibers in the metal media (Figure 38). As a result of oxidation, the porosity of the filter media was reduced, limiting gas flow permeability through the matrix. The thickness of the oxide layers was comparable after 242 and 500 hours of exposure of the Inconel 600 filter media in the $650^{\circ} \mathrm{C}\left(1200^{\circ} \mathrm{F}\right)$ simulated PFBC process gas environment.

After 242 and 500 hours of exposure, the composition of the densified external, $\sim 2 \mu \mathrm{m}$ thick, oxide layer that formed along the outer surface of the Inconel 600 fibers consisted of an oxygen-nickel-iron- or oxygen-nickel-enriched phase. Sulfur appeared to be present within the nickel oxide layer, forming a mottled or filamentous structure. A mottled, $\sim 8 \mu \mathrm{m}$ thick, subsurface layer formed that was enriched with a nickel chromate phase.

Frequently along the o.d. surface of the filtration media, removal of the oxide from the Inconel 600 fibers was observed. In contrast, retention of the oxide scale resulted through the filtration media (i.e., beneath the first fiber layer), encapsulating the $650^{\circ} \mathrm{C}\left(1200^{\circ} \mathrm{F}\right)$, simulated PFBC-exposed, Inconel 600 fibers.
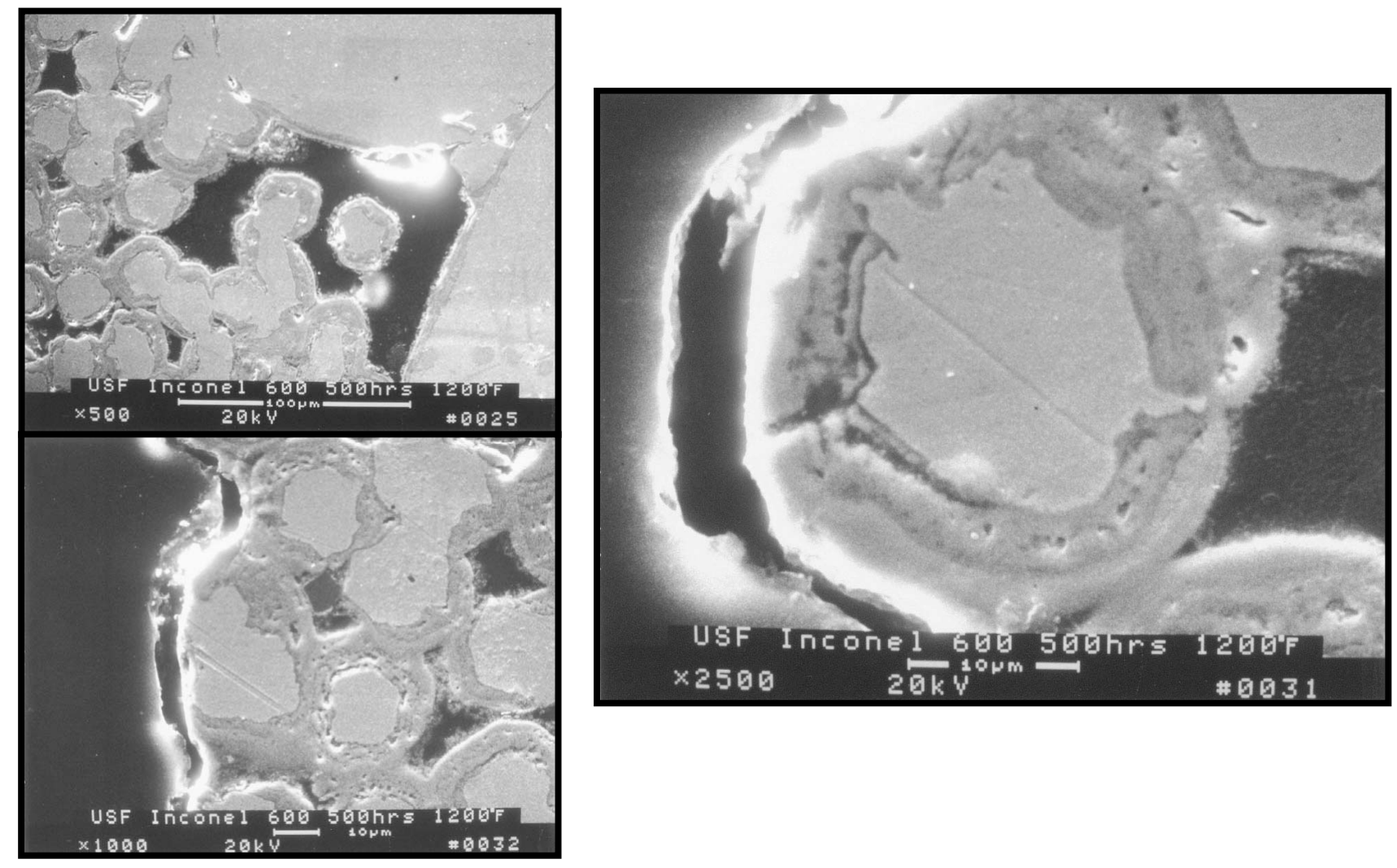

Figure 38 - Morphology of the USF Inconel 600 filtration media after 500 hours of operation in the $650^{\circ} \mathrm{C}\left(1200^{\circ} \mathrm{F}\right)$ simulated $\mathrm{PFBC}$ process gas environment. 
An oxide layer formed along the outer surface of the sinter bonded USF Inconel 600 fibers after $258-1060$ hours of operation in the $760^{\circ} \mathrm{C}\left(1400^{\circ} \mathrm{F}\right)$ simulated $\mathrm{PFBC}$ process gas environment. The thickness of the oxide layer was determined to be $\sim 1.5 \mu \mathrm{m}$ after 258 hours, and $\sim 7.5 \mu \mathrm{m}$ after 1016 hours of operation (Figure 39). Crack formations in the external oxide layer that encapsulated the Inconel 600 fibers were intermittently seen to result. With time, the extent of internal oxidation within the cross-sectioned, sinter bonded, USF Inconel 600 fibers tended to increase.

The composition of the oxide layer appeared to change with continued operating time. After 258 hours of operation in the $760^{\circ} \mathrm{C}\left(1400^{\circ} \mathrm{F}\right)$ simulated PFBC process gas environment, the oxide layer consisted of a chromia/nickel oxide-enriched, or chrome-nickel spinel. Alternately along the continuous amorphous oxide layer that formed along the outer surface of the filter element, the oxide was principally iron/nickel oxide-enriched, with an underlying chromia layer along the base metal interface. After 1016 hours, nickel oxide was detected within the oxidized Inconel 600 fibers that formed a continuous mat. An underlying iron-nickel oxide spinel, and subsequently nickel chromate phase formed.

In localized areas, a continuous oxide layer appeared to have been formed along the outer surface of the filter element, leading to pore closure, restricting gas flow through the filter media.
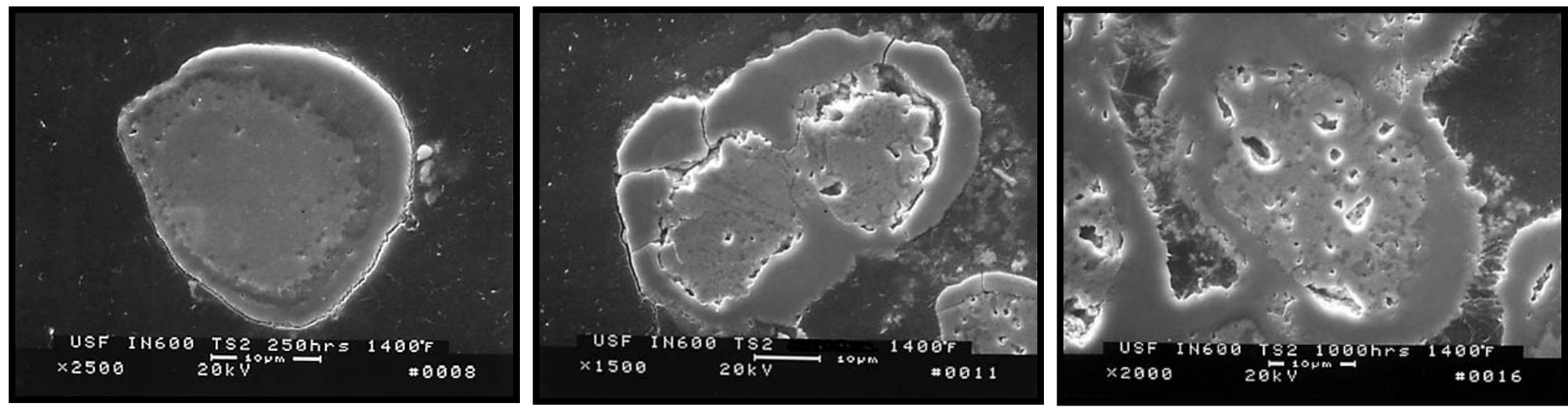

Figure 39 - Morphology of the USF Inconel 600 filtration media after operation in the $760^{\circ} \mathrm{C}$ $\left(1400^{\circ} \mathrm{F}\right)$ simulated $\mathrm{PFBC}$ process gas environment.

Typically a multi-layered oxide formation encapsulated the outer surface of the crosssectioned, sinter bonded, Inconel 600 fibers after 259 to 986 hours of operation of the USF filtration media in the $815-840^{\circ} \mathrm{C}\left(1500-1550^{\circ} \mathrm{F}\right)$ simulated PFBC process gas environment (Figure 40). The thickness of the Inconel 600 surface oxidation layer remained generally constant as a function of filter operating time: $\sim 7.6 \mu \mathrm{m}$ after 259 hours; $\sim 4-7.2 \mu \mathrm{m}$ after 476 hours; and $\sim 8-10 \mu \mathrm{m}$ after 986 hours.

The composition of the external surface oxide layer consisted of nickel oxide. Subsurface layers included $\mathrm{O}-\mathrm{Ni}-\mathrm{Fe}, \mathrm{O}-\mathrm{Ni}, \mathrm{O}-\mathrm{Ni}-\mathrm{Cr}$, and $\mathrm{O}-\mathrm{Cr}-\mathrm{Ni}$. Crack formations were seen to intermittently result within the external Inconel 600 surface oxide. Internal oxidation of the crosssectioned, sinter bonded, Inconel 600 fibers was also observed. 

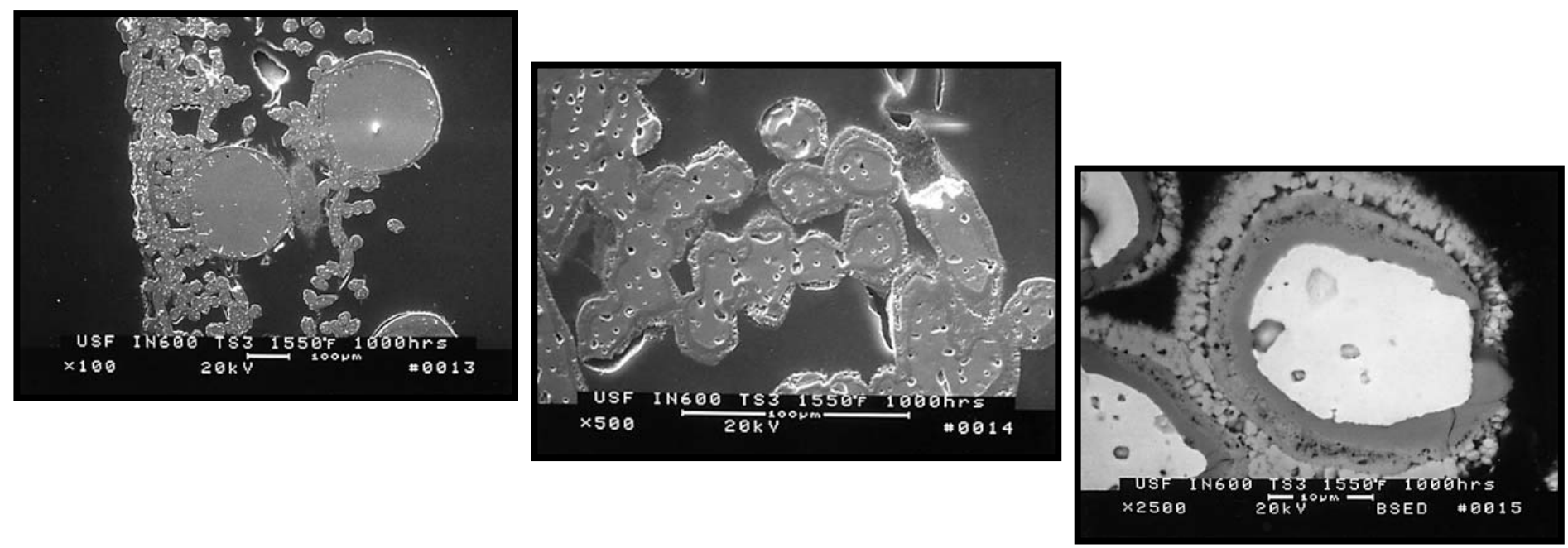

Figure 40 - Microstructure of the USF Inconel 600 filtration media after 986 hours of operation in the $815-840^{\circ} \mathrm{C}\left(1500-1550^{\circ} \mathrm{F}\right)$ simulated $\mathrm{PFBC}$ process gas environment.

In the absence of gas phase sulfur within the $840^{\circ} \mathrm{C}\left(1550^{\circ} \mathrm{F}\right)$ simulated PFBC process gas environment, a continuous amorphous oxide layer formed along the o.d. surface of the 1014 hour, $840^{\circ} \mathrm{C}\left(1550^{\circ} \mathrm{F}\right)$, simulated PFBC-exposed, USF filtration media (Figure 41), restricting gas flow through the filter wall. In addition, extensive oxidation resulted along the outer surface of the sinter bonded Inconel 600 fibers after 253-1014 hours of operation. The thickness of the oxide layer that resulted along the external surface of the cross-sectioned, sinter bonded, USF Inconel 600 fibers tended to slightly increase with extended simulated PFBC operating time: $\sim 6.25 \mu \mathrm{m}$ after 253 hours; $7.5 \mu \mathrm{m}$ after 546.5 hours; $~ 8.3-10 \mu \mathrm{m}$ after 1014 hours.

The composition of the oxide layer that formed along the external surface of the sinter bonded USF Inconel 600 fibers remained relatively constant during 1014 hours of operation. A nickel/nickel oxide-enriched phase formed along the external surface of the sinter bonded Inconel 600 fibers. Subsurface nickel chromate and chromia-enriched layers were subsequently identified. Crack formations within, and separation of the external oxide phase from underlying subsurface oxides, as well as void formations through the cross-sectioned Inconel 600 fibers were evident.

\subsubsection{Impact of Gas Phase Alkali}

Extensive oxidation of the sinter bonded Inconel 600 fibers resulted after 225 to 496 hours of operation of the USF filtration media in the $840^{\circ} \mathrm{C}\left(1550^{\circ} \mathrm{F}\right)$ simulated PFBC process gas environment that contained gas phase alkali and sulfur (Figure 42). A continuous, amorphous, nickel/nickel oxide-enriched layer formed along the o.d. surface of the USF Inconel 600 filter element sections. Localized pore closure resulted, restricting gas flow through the filter media. Void formations were observed along the cross-sectioned surface of the simulated PFBC-exposed, Inconel 600 fibers.

Along discrete sinter bonded Inconel 600 fibers, crack formations were observed through the $\sim 6.7 \mu \mathrm{m}$ thick, multi-phase, external, surface oxide. The oxide consisted of an external O-Ni/Fe- 

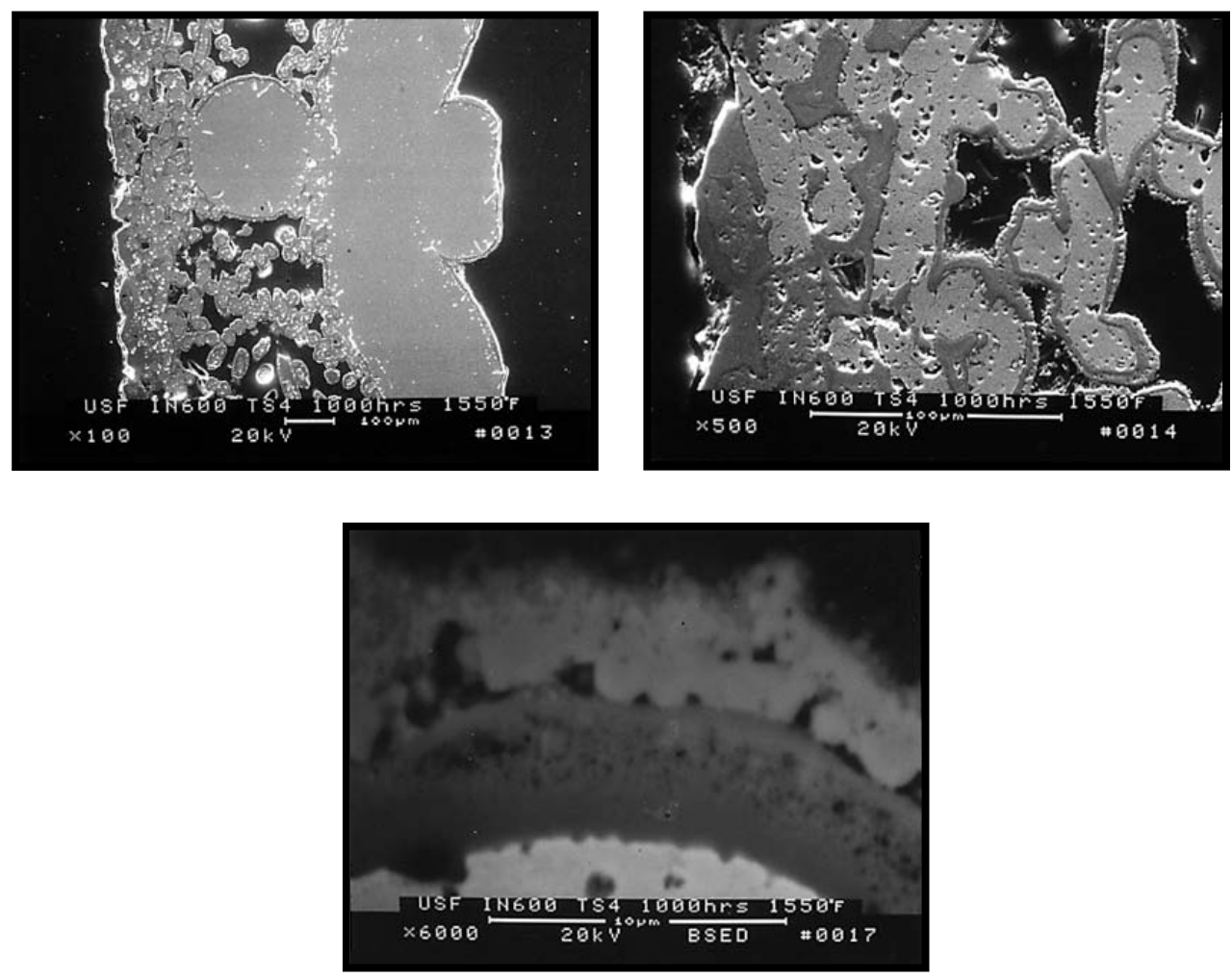

Figure 41 - Morphology of the USF Inconel 600 filtration media after 1014 hours of operation in the sulfur-free simulated PFBC process gas environment.
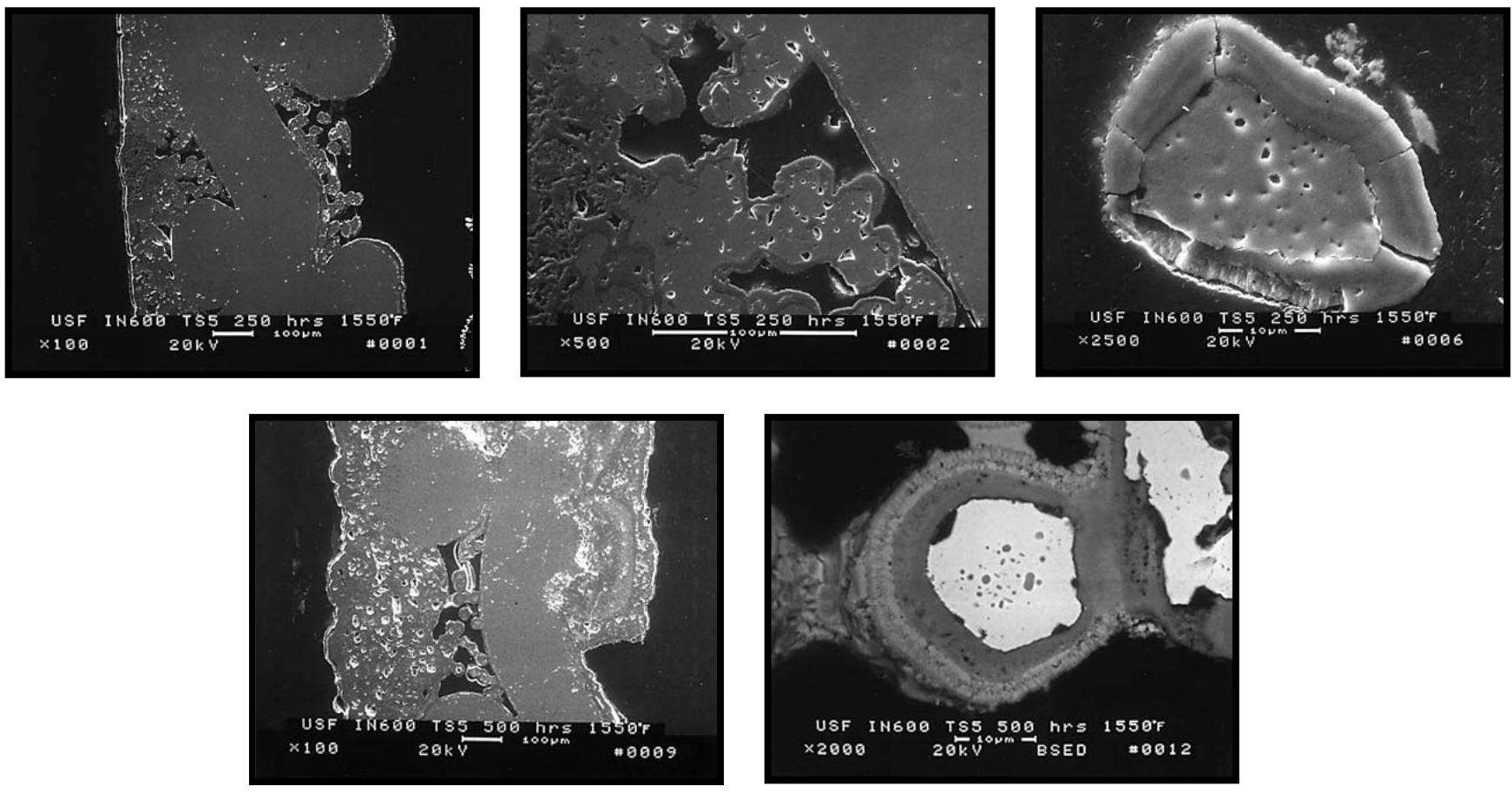

Figure 42 - Microstructure of the USF Inconel 600 filtration media after operation in the $840^{\circ} \mathrm{C}$ $\left(1550^{\circ} \mathrm{F}\right)$ simulated $\mathrm{PFBC}$ process gas environment that contained gas phase sulfur and alkali. 
enriched surface layer. Subsurface nickel/nickel oxide, O-Ni-Cr/Fe, and O-Ni-Cr layers were identified. A chromia-enriched layer was detected along the base metal interface.

\subsection{USF Hastelloy X $-47 \% \mathrm{Ni}, 22 \% \mathrm{Cr}, 19 \% \mathrm{Fe}, 9 \% \mathrm{Mo}, 1.7 \% \mathrm{Co}, 0.6 \% \mathrm{~W}, 0.5 \% \mathrm{Mn}$, $0.3 \% \mathrm{Si}, \mathbf{0 . 0 8 \%} \mathrm{C}$}

\subsubsection{Simulated PFBC Operation}

The open porosity of the $650^{\circ} \mathrm{C}\left(1200^{\circ} \mathrm{F}\right)$, simulated PFBC-exposed, USF Hastelloy X filtration media was retained after 242 and 500 hours of operation (Figure 43). An oxide scale was seen to have formed along the external surface of the sinter bonded Hastelloy $\mathrm{X}$ fibers. The thickness of the oxide scale ranged between $\sim 0.6$ and $4 \mu \mathrm{m}$ after 242 and 500 hours of operation, respectively. The composition of the oxide varied through the thickness of the scale. Typically along the external surface, a nickel-iron-chromium oxide-enriched phase was formed. Enrichment of chromium in the form of a nickel chromate phase tended to result within the subsurface oxide layer.
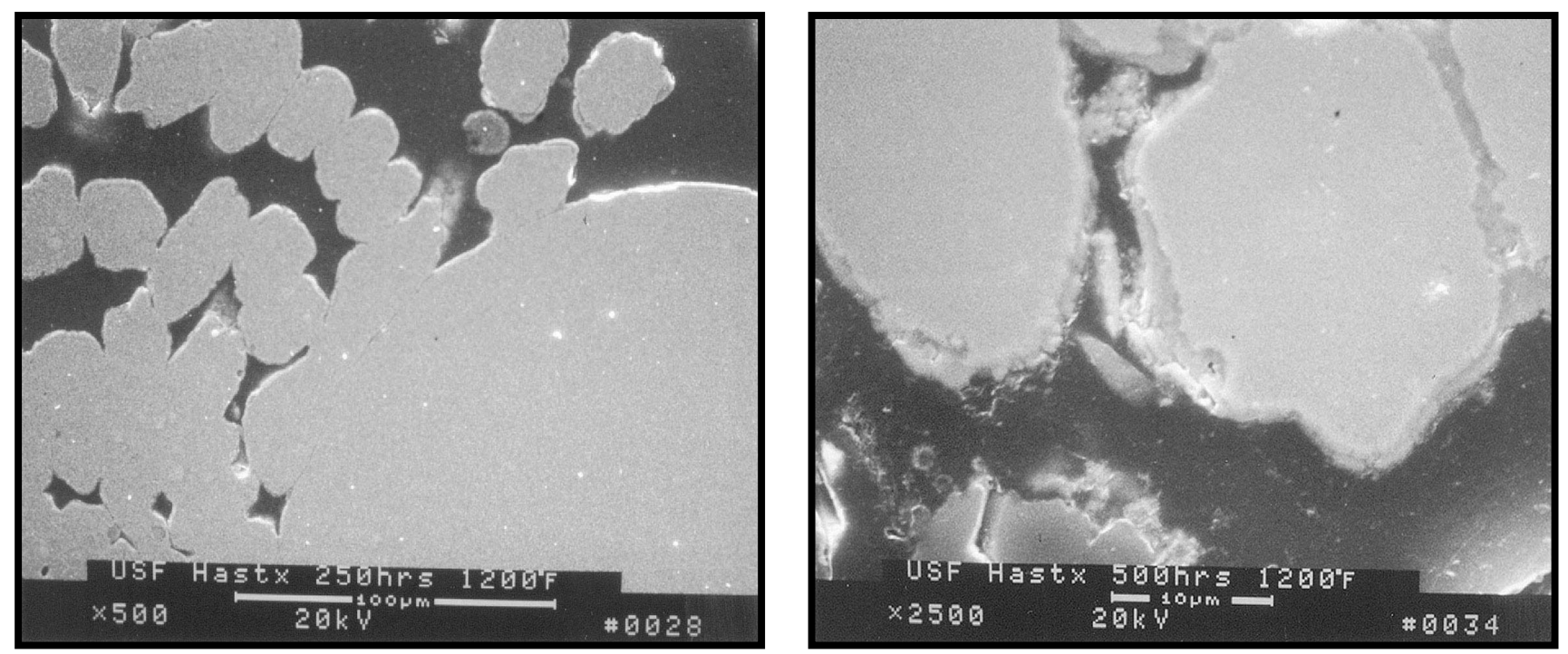

Figure 43 - Morphology of the USF Hastelloy X sinter bonded filtration media after 242 and 500 hours of operation in the $650^{\circ} \mathrm{C}\left(1200^{\circ} \mathrm{F}\right)$ simulated PFBC process gas environment.

External surface and internal oxidation of the sinter bonded Hastelloy X fibers resulted after 258-1016 hours of operation of the USF Hastelloy X filtration media in the $760^{\circ} \mathrm{C}\left(1400^{\circ} \mathrm{F}\right)$ simulated PFBC process gas environment (Figure 44). Localized areas of pore closure were observed within the sinter bonded Hastelloy X filtration media.

The composition of the oxide layer that formed along the surface of the sinter bonded USF Hastelloy X fibers consisted of an external O-Fe-Ni-Cr spinel, and an underlying chromia-enriched subsurface layer. The thickness of the oxide layer ranged from $\sim 3.75$ to $6.6 \mu \mathrm{m}$. Crack formations were detected along the external oxide layer that encapsulated the sinter bonded Hastelloy X fibers that were present along the i.d. or pulse cycled surface of the USF Hastelloy X filtration media. 

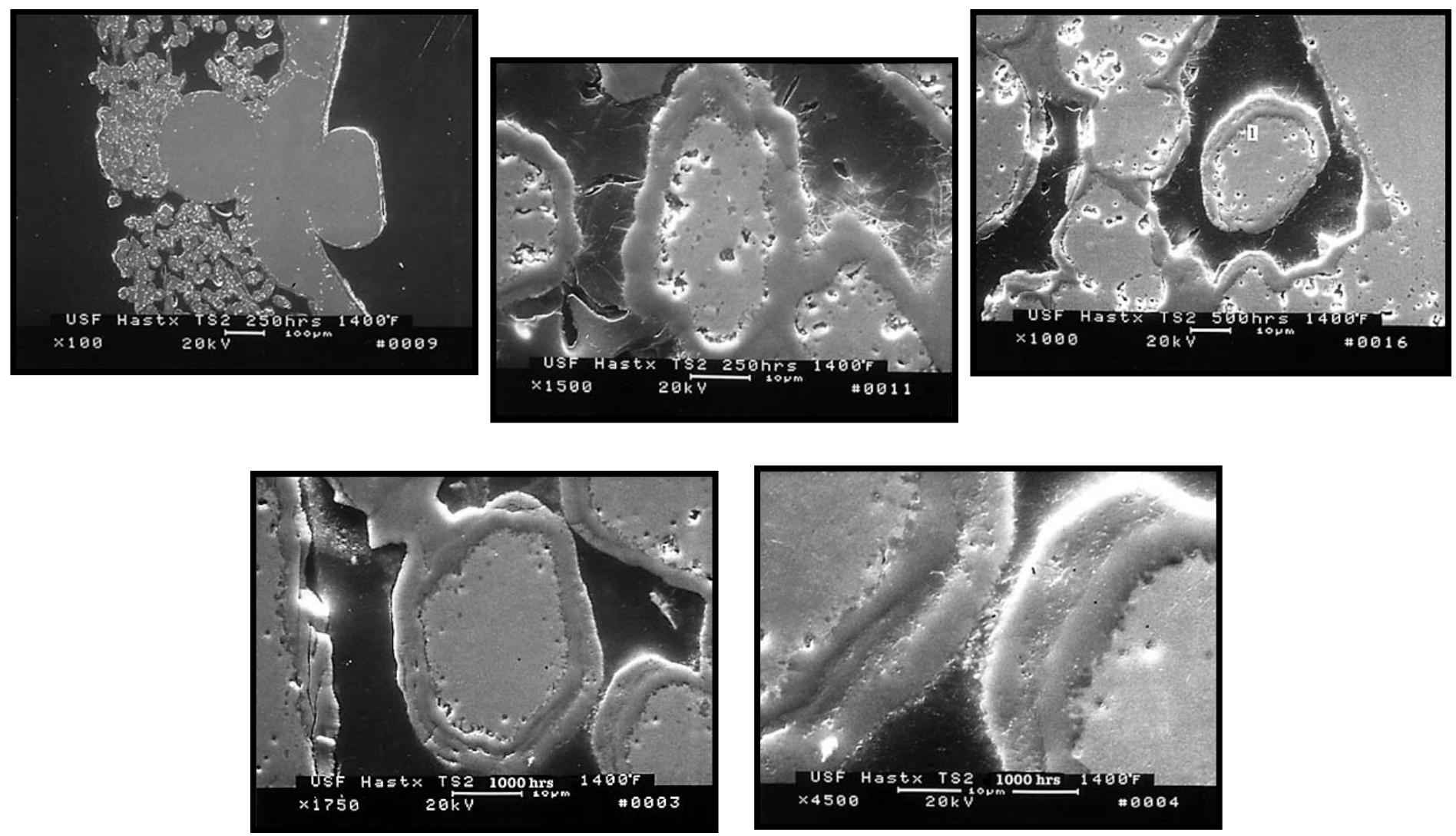

Figure 44 - Morphology of the USF Hastelloy X filtration media after 258-1016 hours of operation in the $760^{\circ} \mathrm{C}\left(1400^{\circ} \mathrm{F}\right)$ simulated PFBC process gas environment. The lower right micrograph illustrates the thickness of the various oxide layers that resulted after 1016 hours.

Extensive oxidation of the sinter bonded Hastelloy X fibers resulted after 259-986 hours of operation of the USF Hastelloy $X$ filter element sections in the $815-840^{\circ} \mathrm{C}\left(1500-1550^{\circ} \mathrm{F}\right)$ simulated PFBC process gas environment. Pore closure resulted in localized areas along the outer surface of the USF Hastelloy X filtration media, particularly after 986 hours of operation.

The thickness of the external oxide layer ranged from $\sim 1.6$ to $4.3 \mu \mathrm{m}$ (Figure 45 ). The thickness of the oxide layer appeared to minimally increase with extended operating time: $~ 1.6-3.6$ $\mu \mathrm{m}$ after 259 hours; $\sim 2.4-3.3 \mu \mathrm{m}$ after 476 hours; $\sim 3.1-4.3 \mu \mathrm{m}$ after 986 hours. The composition of the outer surface of the oxide layer that encapsulated the sinter bonded Hastelloy $\mathrm{X}$ fibers tended to vary with time. After 259 hours, an O-Cr-Ni-Fe spinel formed. After 476 hours, an O-Fe-Ni/Crrich spinel resulted. After 986 hours, an $\mathrm{O}-\mathrm{Ni}-\mathrm{Fe}-\mathrm{Cr}$ phase was observed. Irrespective of the operating time, a chromia-enriched subsurface layer was detected.

Internal oxidation also resulted throughout the cross-sectioned, sinter bonded, USF Hastelloy X fibers. Crack formations were also observed throughout the external oxide layer that encapsulated the sinter bonded, Hastelloy X fibers along the outer surface, as well as i.d. or pulse cycled surface of the USF filtration media. 

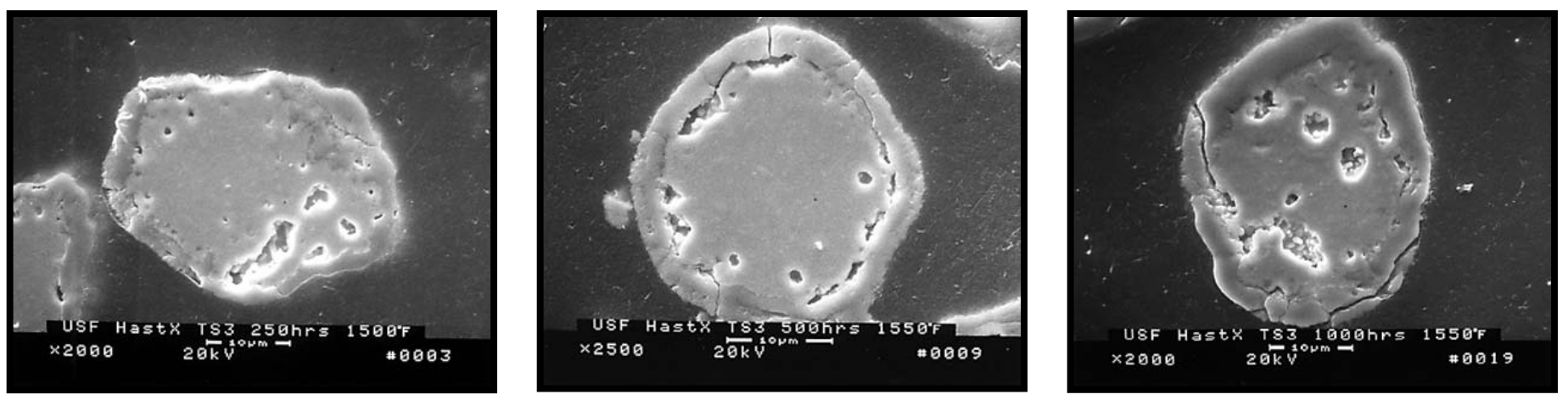

Figure 45 - Morphology of the sinter bonded USF Hastelloy $\mathrm{X}$ fibers as a result of operation in the $815-840^{\circ} \mathrm{C}\left(1500-1550^{\circ} \mathrm{F}\right)$ simulated $\mathrm{PFBC}$ process gas environment.

Similarly, extensive external surface oxidation, as well as internal oxidation of the sinter bonded Hastelloy X fibers contained within the USF filtration media resulted after 253 to 1014 hours of operation in the $840^{\circ} \mathrm{C}\left(1550^{\circ} \mathrm{F}\right)$, sulfur-free, simulated PFBC process gas environment. Pore closure resulted along the oxidized outer surface of the USF Hastelloy X filtration media after 546.5 to 1014 hours of operation (Figure 46).

The thickness of the oxidized layer that formed along discrete (i.e., isolated) Hastelloy $\mathrm{X}$ fibers was $\sim 2.7-4.2 \mu \mathrm{m}$. Spinel formations (O-Cr-Ni-Fe; O-Fe-Ni-Cr) resulted along the external surface of the oxidized Hastelloy $\mathrm{X}$ fibers, while an underlying chromia-enriched subsurface layer formed.

Cracks were identified within the oxide layer that formed along the external surface of the Hastelloy X fibers that were present along the i.d. or pulse cycled surface of the 546.5 hour, $840^{\circ} \mathrm{C}$ $\left(1550^{\circ} \mathrm{F}\right)$, simulated PFBC-exposed, USF filtration media.
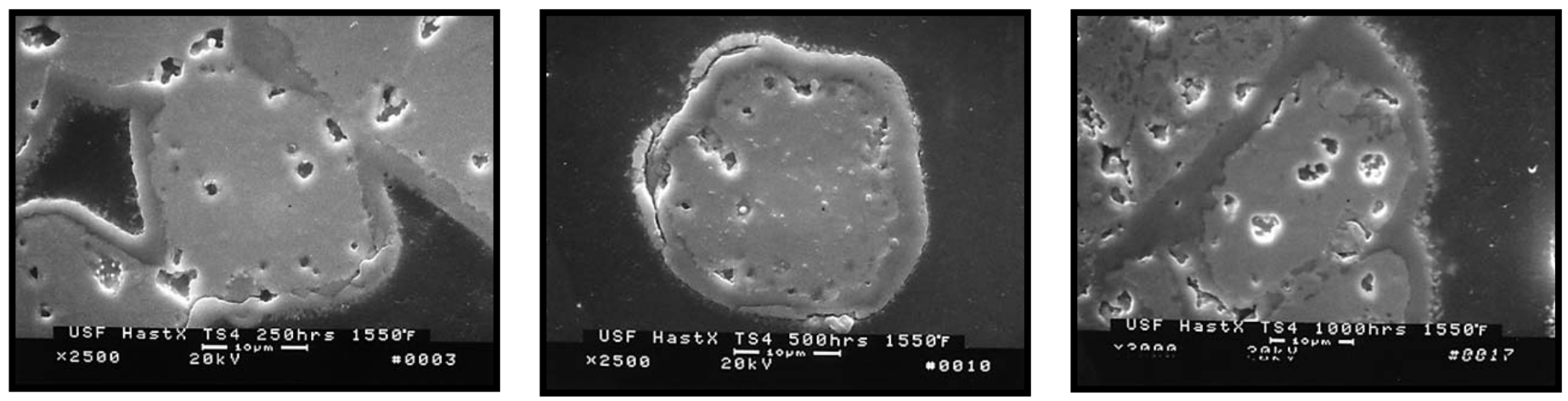

Figure 46 - Microstructure of the USF Hastelloy X filtration media after operation in the sulfurfree simulated PFBC process gas environment. 


\subsubsection{Impact of Gas Phase Alkali}

Extensive external, as well as internal oxidation of the sinter bonded Hastelloy $\mathrm{X}$ fibers resulted after $225-496$ hours of operation of the USF filtration media in the $840^{\circ} \mathrm{C}\left(1550^{\circ} \mathrm{F}\right)$ simulated PFBC process gas environment that contained gas phase sulfur and alkali (Figure 47). Pore closure was observed which restricted gas flow through the filter media.

Along the outer surface of discrete Hastelloy $\mathrm{X}$ fibers, an $\sim 1.8-2.5 \mu \mathrm{m}$ thick oxide layer was seen to have formed after 225 hours of operation. The composition of the outer surface of the oxide consisted of an $\mathrm{O}-\mathrm{Ni}-\mathrm{Cr}-\mathrm{Fe}$ spinel, and an underlying chromia-enriched subsurface oxide. Low concentrations of sulfur were detected within the subsurface oxide formation.
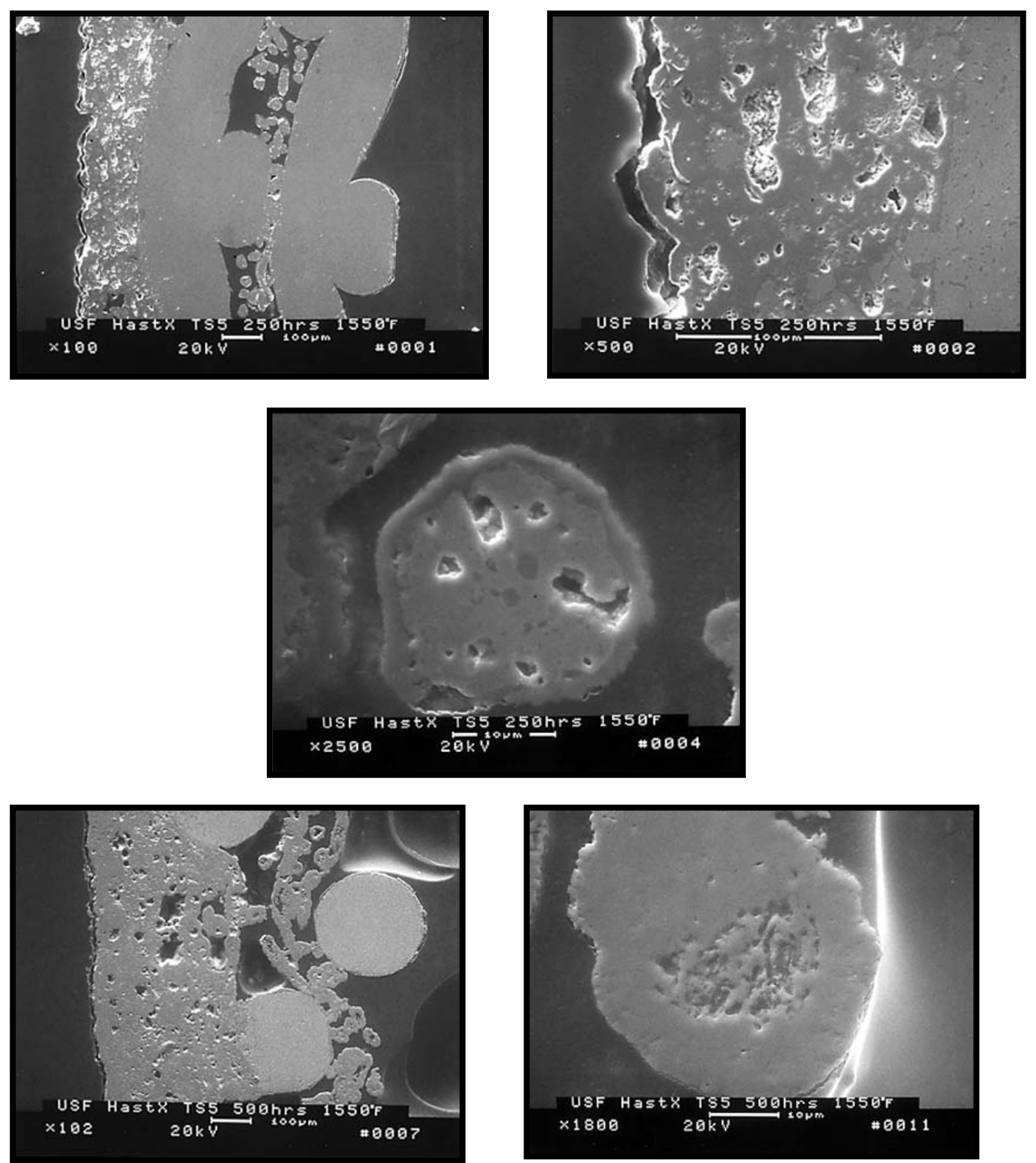

Figure 47 - Morphology of the USF Hastelloy X filtration media after operation in the $840^{\circ} \mathrm{C}$ $\left(1550^{\circ} \mathrm{F}\right)$ simulated $\mathrm{PFBC}$ process gas environment that contained gas phase sulfur and alkali. 


\subsection{Pall 310S - Fe Bal; 25\% Cr, 20.5\% Ni, $1.6 \% \mathrm{Mn}, 0.75 \% \mathrm{Mo}, 0.5 \% \mathrm{Si}, 0.05 \% \mathrm{C}$}

\subsubsection{Simulated PFBC Operation}

Based on microstructural analyses, a more porous matrix appeared to exist along the outer and inner surfaces of the as-manufactured Pall $310 \mathrm{~S}$ sinter powder metal filtration media in contrast to a more densified center section. The open porosity of the Pall 310 filter matrix appeared to have been retained after 242 and 500 hours of operation in the $650^{\circ} \mathrm{C}\left(1200^{\circ} \mathrm{F}\right)$ simulated $\mathrm{PFBC}$ operating environment (Figure 48).

After 242 hours of operation, an $\sim 1 \mu \mathrm{m}$ chromium-iron-oxide-enriched scale formed along the surface of the sinter bonded Pall 310S particles. With continued exposure, the thickness of the oxide scale increased to $\sim 4-7 \mu \mathrm{m}$. Crack formations were frequently detected within the oxide scale, with spallation resulting, exposing areas of the base metal media. The composition of the $\sim 4-$ $7 \mu \mathrm{m}$ oxide scale was typically enriched with chromia and/or iron chromate.

Internal oxidation was evident along the surface of the 500 hour, $650^{\circ} \mathrm{C}\left(1200^{\circ} \mathrm{F}\right)$, simulated PFBC-exposed, Pall 310 S sinter bonded particles, as well as oxidation along the sinter bonds that remained between adjacent particles within the filtration media.
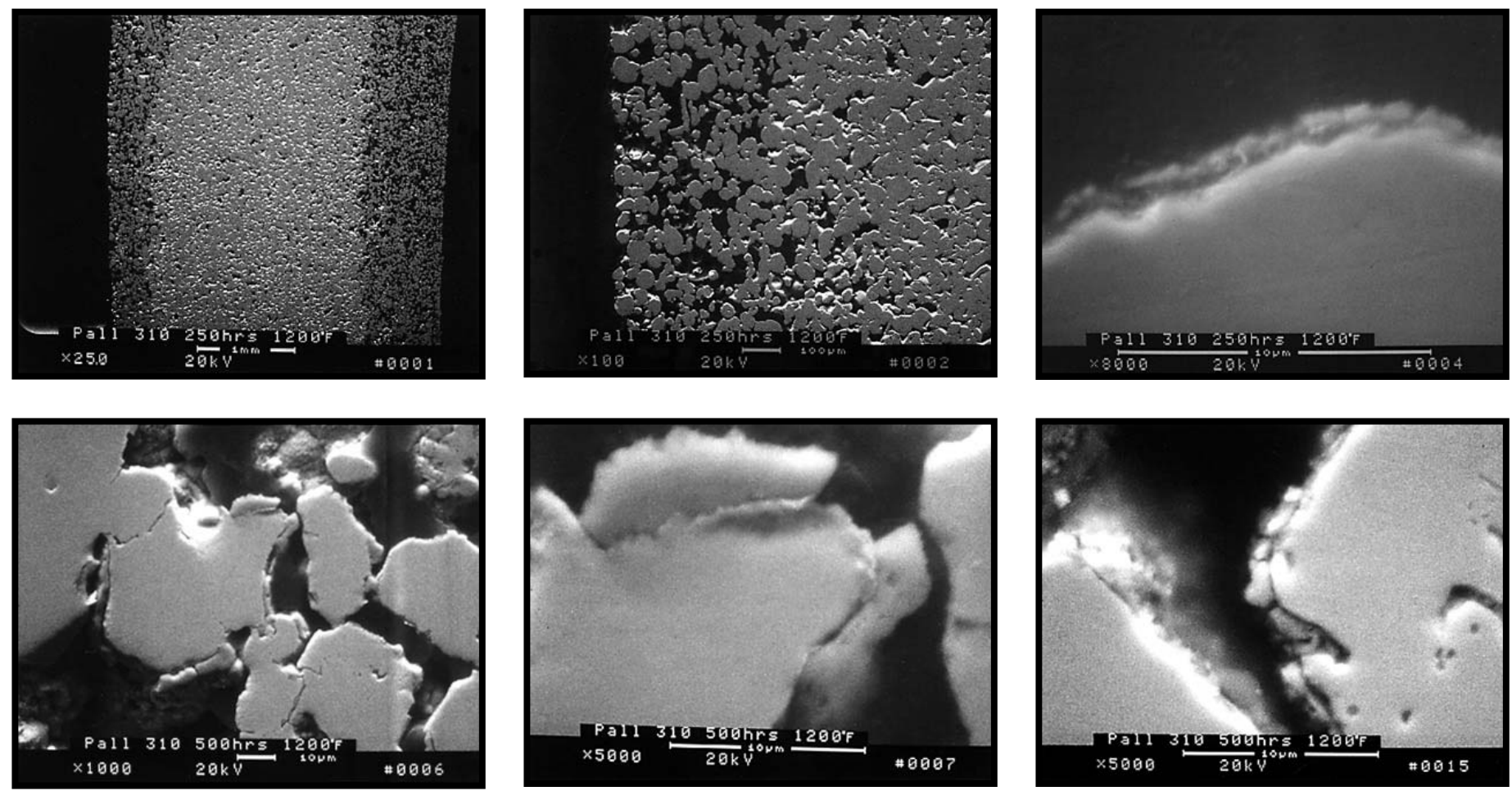

Figure 48 - Morphology of the Pall 310S filtration media after operation in the $650^{\circ} \mathrm{C}\left(1200^{\circ} \mathrm{F}\right)$ simulated PFBC process gas environment. 
The open porosity of the sinter bonded powder, Pall 310S filter media was retained throughout the $\sim 3 \mathrm{~mm}$ thick cross-sectioned filter wall after 258 hours of operation in the simulated $760^{\circ} \mathrm{C}\left(1400^{\circ} \mathrm{F}\right) \mathrm{PFBC}$ environment. High temperature oxidation of the filter media lead to both internal oxidation of the sinter bonded $310 \mathrm{~S}$ particles, and the formation of an $\sim 6 \mu \mathrm{m}$ thick oxide layer along the outer surface of the $310 \mathrm{~S}$ Pall particles (Figure 49). The external surface of the oxide layer contained iron oxide, and subsequently iron chromate. Frequently the external oxide layer was separated from the subsurface $\mathrm{O}-\mathrm{Ni}-\mathrm{Cr}$ or $\mathrm{O}-\mathrm{Cr}-\mathrm{Ni}-\mathrm{Fe}$ spinel. Chromia typically formed at the oxide/metal substrate interface.
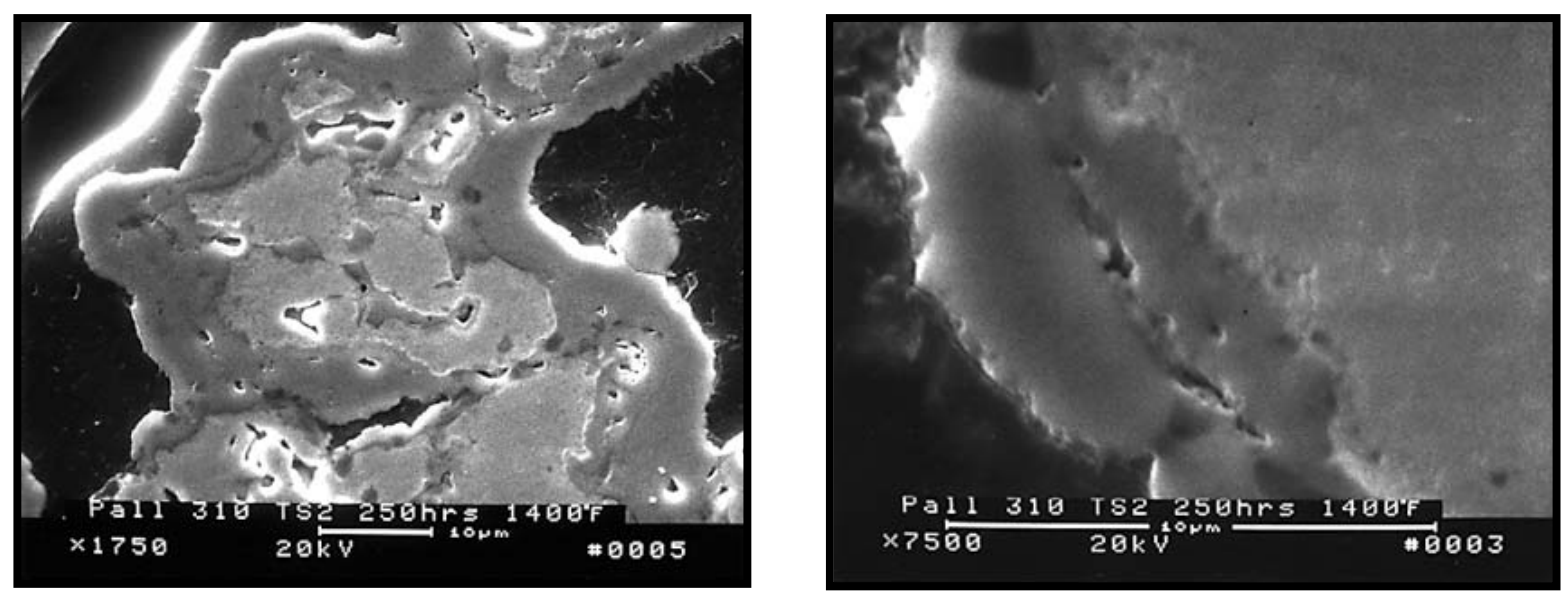

Figure 49 - Morphology of the Pall 310S filtration media after 258 hours of operation in the $760^{\circ} \mathrm{C}\left(1400^{\circ} \mathrm{F}\right)$ simulated $\mathrm{PFBC}$ process gas environment.

Failure of the Pall $310 \mathrm{~S}$ filter media typically resulted with extended $760^{\circ} \mathrm{C}\left(1400^{\circ} \mathrm{F}\right)$ simulated PFBC operation, as well as at higher simulated PFBC operating temperatures. The fresh fractured surfaces initiating at the weld and traversing the filtration wall were similar to the fractures resulting for monolithic ceramic filter matrices under thermal fatigue or shock conditions (Figure 50). As a result of failure of the Pall $310 \mathrm{~S}$ filtration media, additional characterization was not undertaken, since use of this matrix at higher operating temperatures was designated as not feasible.

\subsubsection{Impact of Gas Phase Alkali}

In the presence of gas phase sulfur and alkali, densification resulting from oxidation of the porous Pall $310 \mathrm{~S}$ filter media resulted along the o.d. and i.d. surfaces of the $840^{\circ} \mathrm{C}\left(1550^{\circ} \mathrm{F}\right)$, simulated PFBC-exposed, $\sim 3 \mu \mathrm{m}$ thick filter wall (Figure 51). Densification of the Pall 310S media extended $\sim 1 \mathrm{~mm}$ along both surfaces of the cross-sectioned filter wall. As a result, pore closure of the filter media occurred, restricting gas flow through the filter element. In contrast, open porosity was seen to exist along an $\sim 1 \mathrm{~mm}$ thick area along the mid-section of the cross-sectioned Pall $310 \mathrm{~S}$ filter element.

The thickness of the external oxide layer that formed along the o.d. surface of the $840^{\circ} \mathrm{C}$ $\left(1550^{\circ} \mathrm{F}\right)$, gas phase sulfur and alkali-laden, PFBC-exposed, Pall $310 \mathrm{~S}$ filter element ranged 
between $\sim 6.6$ to $\sim 8.3 \mu \mathrm{m}$ (Figure 52 ). Two distinct oxides layers were present. The external oxide layer consisted principally of iron oxide, with an $\mathrm{O}-\mathrm{Ni}-\mathrm{Fe}$ spinel formed at the base metal interface.

Extensive external oxidation similarly resulted along the sinter bonded particles that were present along the i.d. or pulse cycled surface of the $840^{\circ} \mathrm{C}\left(1550^{\circ} \mathrm{F}\right)$, gas phase sulfur and alkaliladen, PFBC-exposed Pall 310S filter element (Figure 53). The composition of the external surface of the oxide layer consisted principally of iron oxide, with an underlying chromia formation. In addition to the extensive external surface oxidation that resulted along the o.d. and i.d. surfaces of the Pall 310S filter element, internal oxidation of the sinter bonded 310S particles also occurred.

Where the open porosity existed along the mid-section of the $840^{\circ} \mathrm{C}\left(1550^{\circ} \mathrm{F}\right)$, gas phase sulfur and alkali-laden, PFBC-exposed, Pall 310S filter element, chromia-enriched whisker-like features were seen to extend from the surface of the sinter boned 310S particles (Figure 54). An underlying chromia layer was seen to form at the base metal interface.

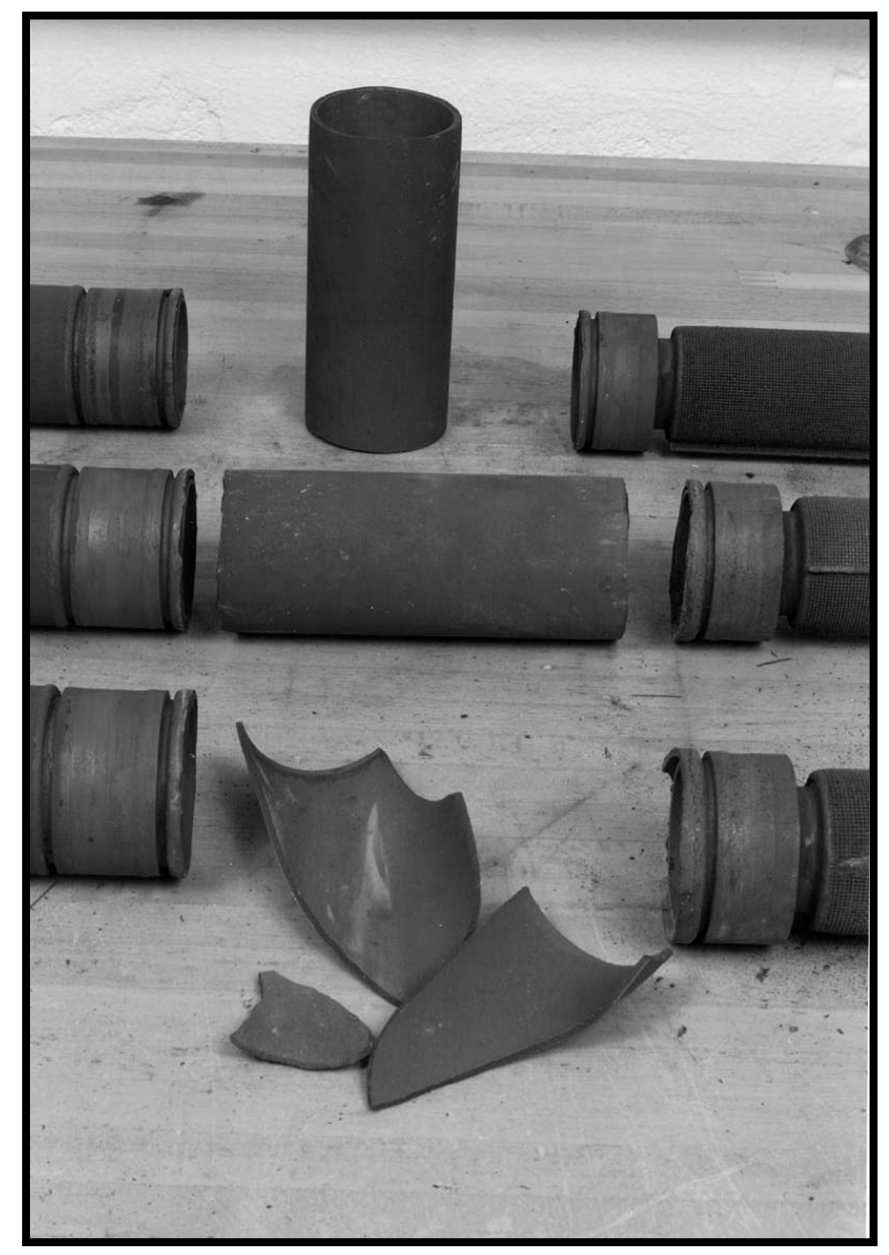

Figure 50 - Fracture characteristics of the Pall $310 \mathrm{~S}$ filtration media at $\geq 650^{\circ} \mathrm{C}\left(\geq 1400^{\circ} \mathrm{F}\right)$ simulated PFBC operating temperatures. 

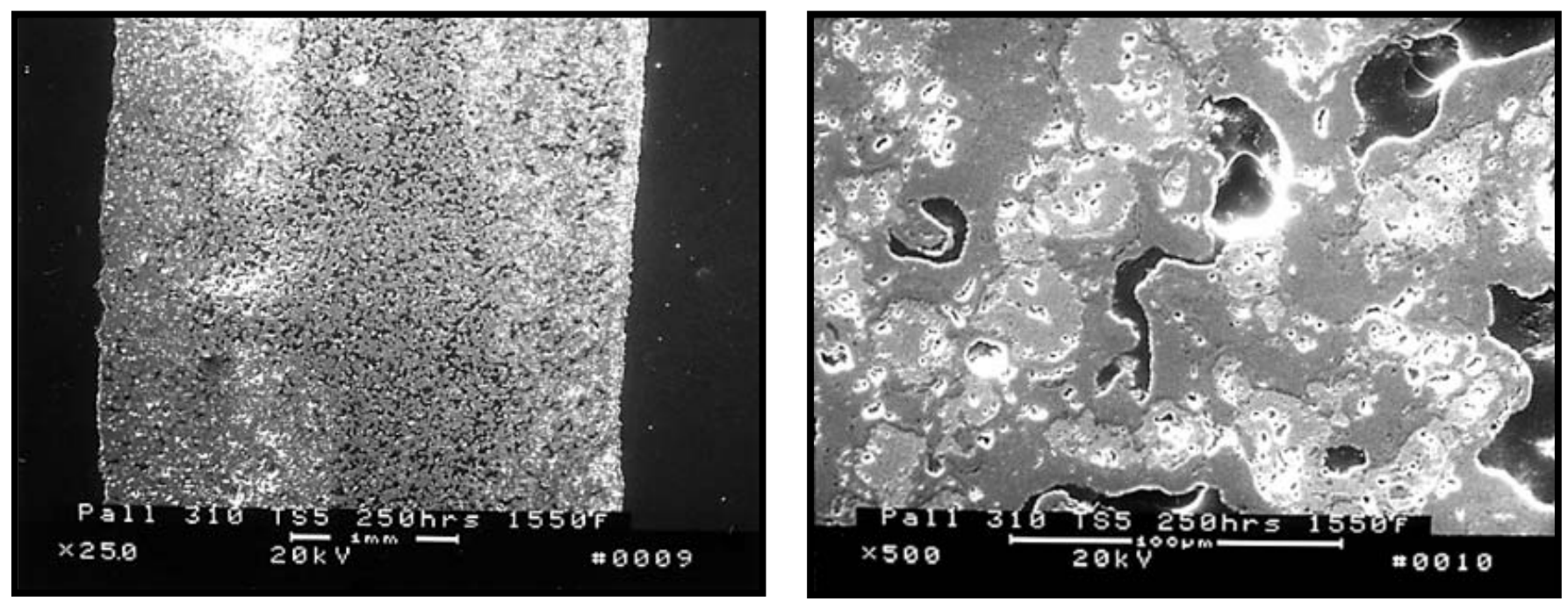

Figure 51 - Morphology of the Pall 310S filtration media after 225 hours of operation in the $840^{\circ} \mathrm{C}\left(1550^{\circ} \mathrm{F}\right)$, gas phase sulfur and alkali-containing, simulated PFBC process gas environment (o.d. surface).

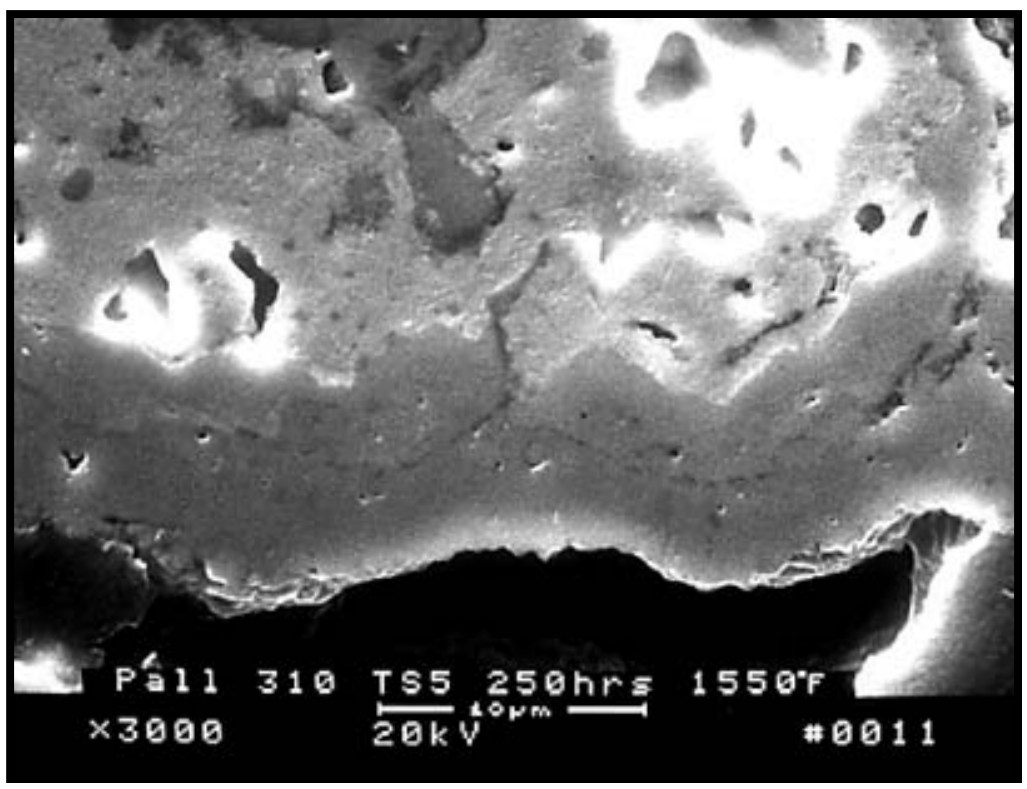

Figure 52 - Higher magnification micrographs illustrating the thickness and morphology of the oxide layer that formed along the outer surface of the 225 hour, $840^{\circ} \mathrm{C}\left(1550^{\circ} \mathrm{F}\right)$, gas phase sulfur and alkali-containing, simulated PFBC-exposed, sinter bonded, Pall 310S particles (o.d. surface). 


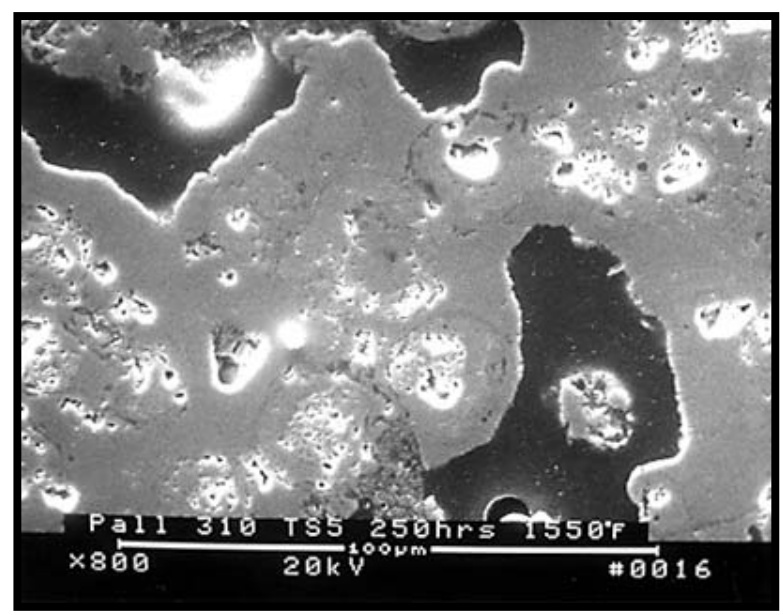

Figure 53 - Higher magnification micrographs illustrating the extensive surface and internal oxidation that resulted along and within the sinter bonded Pall $310 \mathrm{~S}$ particles after 225 hours of operation in the $840^{\circ} \mathrm{C}\left(1550^{\circ} \mathrm{F}\right)$, gas phase sulfur and alkali-containing, simulated PFBC process gas environment.
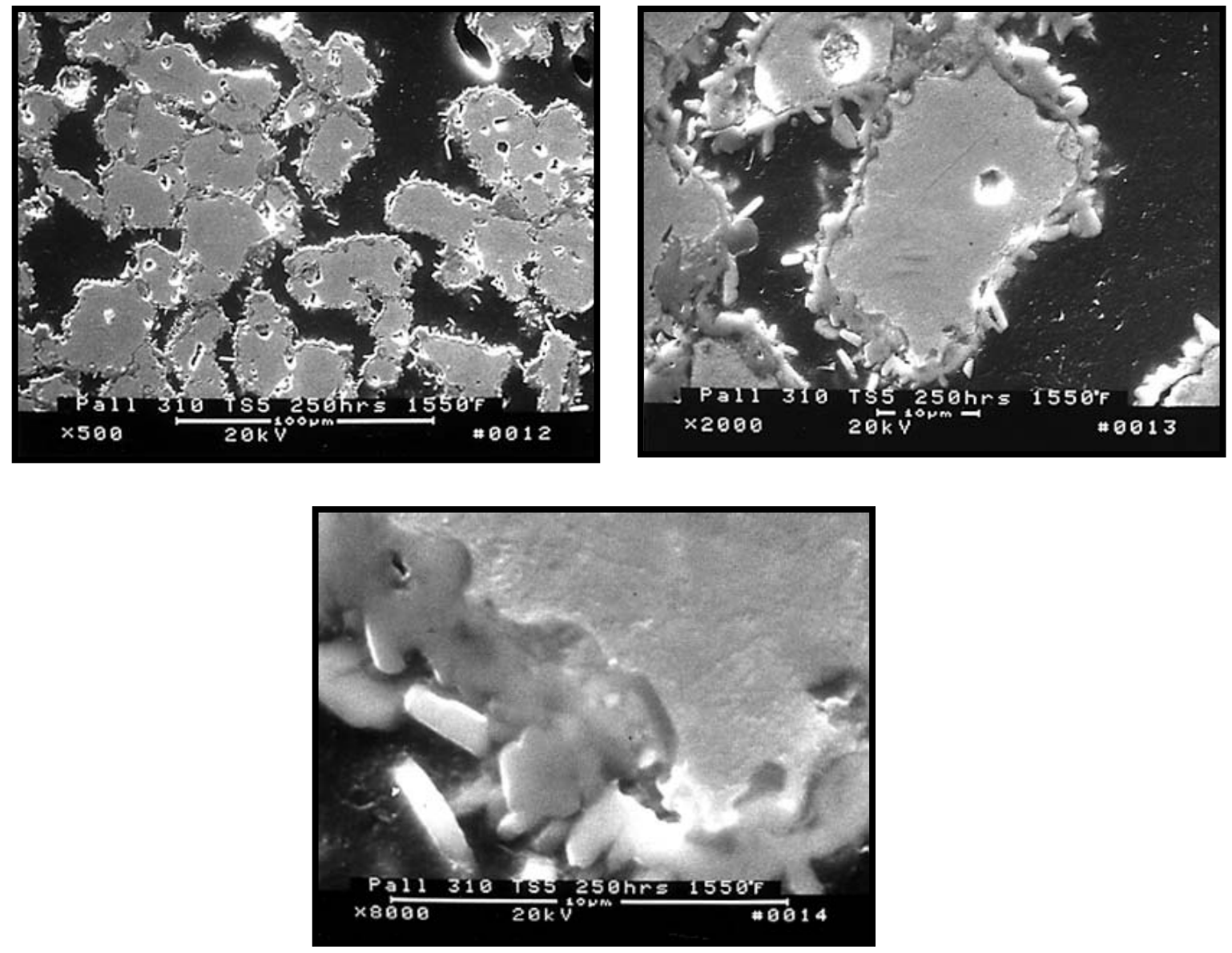

Figure 54 - Morphology of the cross-sectioned, sinter bonded, Pall 310S particles along the midsection of the 225 hour, $840^{\circ} \mathrm{C}\left(1550^{\circ} \mathrm{F}\right)$, gas phase sulfur and alkali-containing, simulated PFBC-exposed, filter wall. 


\subsection{Pall Hastelloy $\mathrm{X}-47 \% \mathrm{Ni}, 22 \% \mathrm{Cr}, 19 \% \mathrm{Fe}, 9 \% \mathrm{Mo}, 1.7 \% \mathrm{Co}, 0.6 \% \mathrm{~W}, 0.5 \% \mathrm{Mn}$, $0.3 \% \mathrm{Si}, \mathbf{0 . 0 8 \%} \mathrm{C}$}

\subsubsection{Simulated PFBC Operation}

The open porosity of the Pall Hastelloy X filter media was retained after 242 hours of operation in the $650^{\circ} \mathrm{C}\left(1200^{\circ} \mathrm{F}\right)$ simulated PFBC process gas environment. Under these conditions an $\sim 4 \mu \mathrm{m}$ thick scale intermittently formed along the external surface of the Pall Hastelloy X sinter bonded particles (Figure 55). The external scale contained numerous crack formations and was enriched a nickel-chromium-iron oxide layer. A thinner, more continuous, subsurface oxide was also detected which was principally enriched with a nickel chromium-containing phase.

Limited or negligible oxidation typically resulted throughout the porous Pall Hastelloy $\mathrm{X}$ filter media after 500 hours of exposure at $650^{\circ} \mathrm{C}\left(1200^{\circ} \mathrm{F}\right)$ in the simulated PFBC process gas environment.
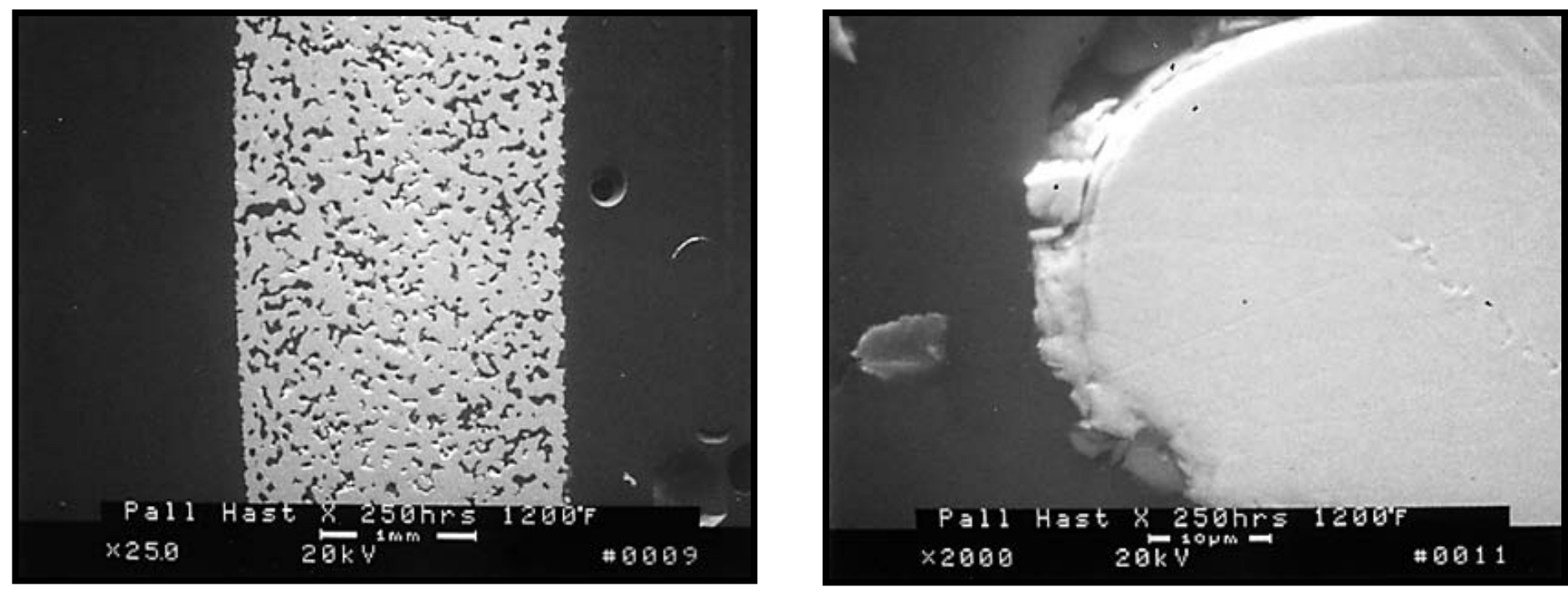

Figure 55 - Morphology of the Pall Hastelloy X filtration media after 242 hours of operation in the $650^{\circ} \mathrm{C}\left(1200^{\circ} \mathrm{F}\right)$ simulated $\mathrm{PFBC}$ process gas environment.

The open porosity of the Pall Hastelloy X filter media was retained after 258, 524.5, and 1016 hours of operation in the $760^{\circ} \mathrm{C}\left(1400^{\circ} \mathrm{F}\right)$ simulated PFBC process gas environment. After 258 hours of exposure, an $\sim 6 \mu \mathrm{m}$ thick oxide layer formed along the outer surface of the sinter bonded Pall Hastelloy X particles that were present along the o.d. surface of the filter element (Figure 56). The composition of the external $\sim 5 \mu \mathrm{m}$ thick oxide layer consisted primarily of an $\mathrm{O}-$ Ni-Fe spinel. Directly beneath this layer was an $\sim 1 \mu \mathrm{m}$ thick chromia-enriched layer. In contrast, an oxide layer intermittently was seen to have formed along the surface of the sinter bonded Hastelloy X particles that were present along the mid-section of the 258 hour, $760^{\circ} \mathrm{C}\left(1400^{\circ} \mathrm{F}\right)$, 

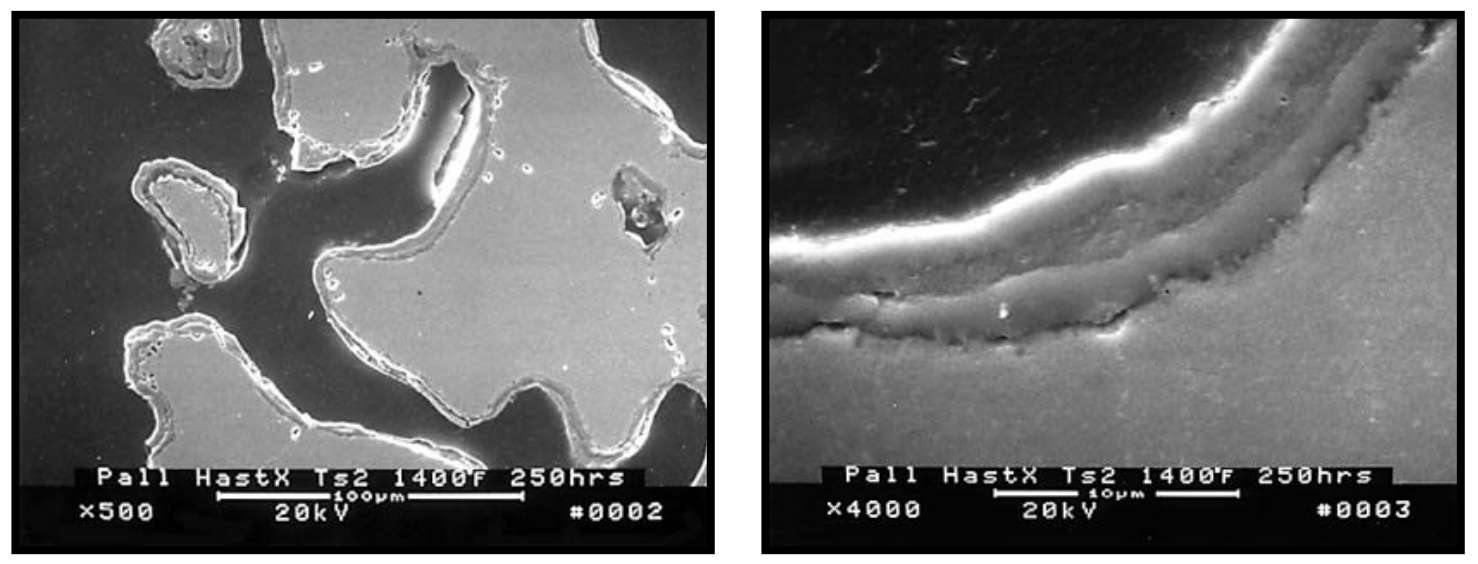

(a)

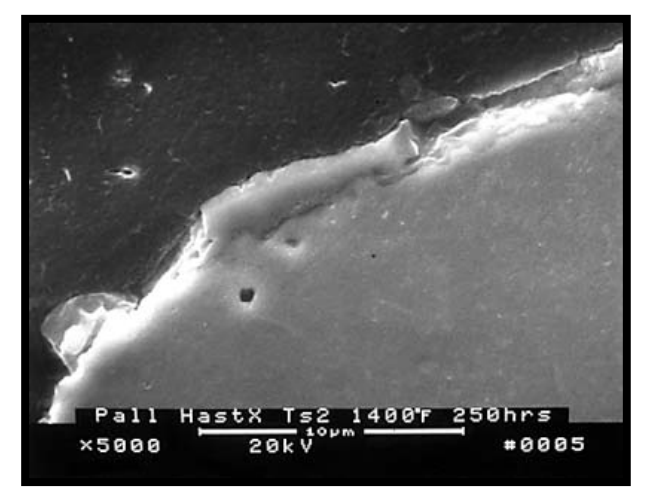

(b)
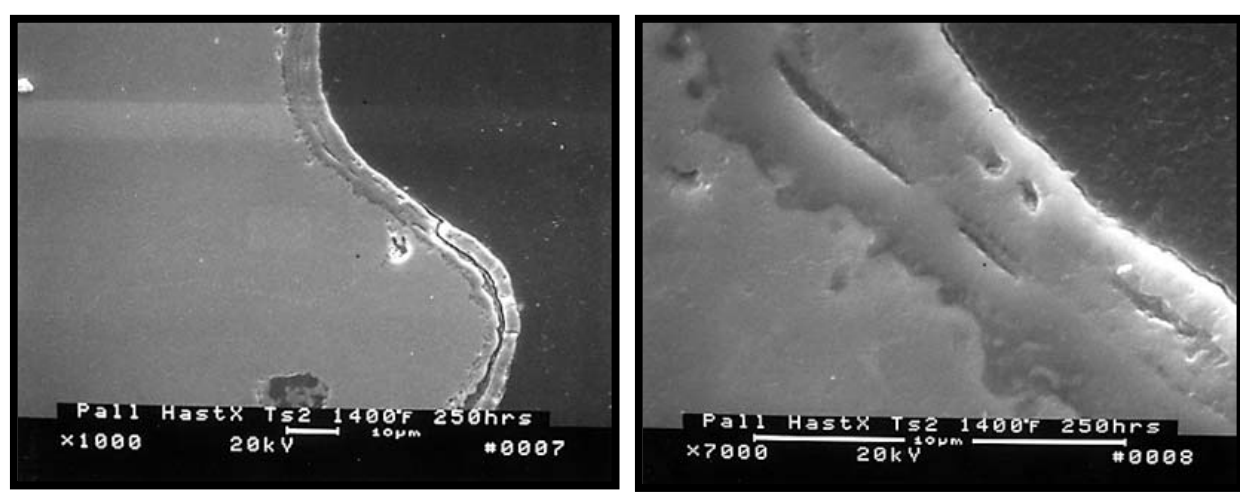

(c)

Figure 56 - Microstructure of the Pall Hastelloy X filtration media after 258 hours of operation in the $760^{\circ} \mathrm{C}\left(1400^{\circ} \mathrm{F}\right)$ simulated $\mathrm{PFBC}$ process gas environment. (a) o.d. surface; (b) Mid-section; (c) Pulse cycled or i.d. surface.

simulated PFBC-exposed, Pall filter media. Along the i.d. or pulse cycled surface, an $\sim 4.3-5.7 \mu \mathrm{m}$ thick oxide layer formed along the surface of the Hastelloy $\mathrm{X}$ sinter bonded particles. The composition of the external surface was nickel oxide, with an underlying O-Fe-Ni spinel phase, and subsequently an $\sim 1.4 \mu \mathrm{m}$ thick chromia-enriched phase formed adjacent to the base metal interface.

After 524.5 hours of exposure in the $760^{\circ} \mathrm{C}\left(1400^{\circ} \mathrm{F}\right)$ simulated $\mathrm{PFBC}$ process gas environment, surface oxidation of the sinter bonded Pall Hastelloy X particles resulted. Internal oxidation and pitting of the underlying base metal directly below the surface oxide formation, and oxidation along the sinter bonded grain (particle) boundaries were evident (Figure 57). The composition of the oxide formation that resulted along the sinter bonded Hastelloy X particles that were present along the o.d. surface of the filter element consisted of an O-Ni-Fe spinel phase, and an underlying chromia-enriched layer. Along the i.d. or pulse cycled surface of the 524.5 hour, $760^{\circ} \mathrm{C}\left(1400^{\circ} \mathrm{F}\right)$, simulated PFBC-exposed, Pall Hastelloy X particles, the composition of the outer surface oxide layer included $\mathrm{O}-\mathrm{Cr}-\mathrm{Ni}$, with a chromia-enriched layer formed along the base metal interface. 


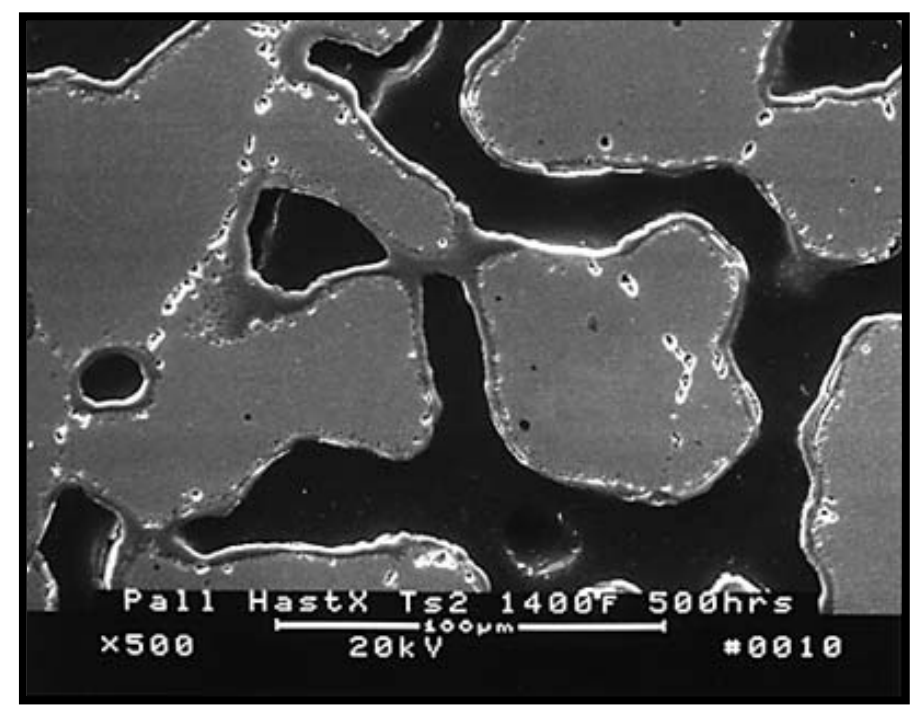

Figure 57 - Micrograph illustrating the morphology of the Pall Hastelloy X filter media after 524.5 hours of $760^{\circ} \mathrm{C}\left(1400^{\circ} \mathrm{F}\right)$ simulated PFBC operation.

After 1016 hours of exposure in the $760^{\circ} \mathrm{C}\left(1400^{\circ} \mathrm{F}\right)$ simulated PFBC environment, surface oxidation, as well as internal oxidation along the sinter bonds between adjacent Pall Hastelloy $\mathrm{X}$ particles was evident (Figure 58). The composition of the $\sim 2.85-5 \mu \mathrm{m}$ thick oxide layer that formed along the outer surface of the Pall Hastelloy X sinter bonded particles that were present along the o.d. surface of the filter element consisted of an external O-Cr-Ni layer, and an underlying chromiaenriched layer. Along the i.d. or pulse cycled surface of the filter element, an $\sim 3.5-8.75 \mu \mathrm{m}$ thick oxide layer was seen to have formed along the outer surface of the sinter bonded Pall Hastelloy X particles. Two distinct oxide layers were observed. The composition of the external oxide layer consisted of $\mathrm{O}-\mathrm{Ni}-\mathrm{Fe}-\mathrm{Cr}$, while an underlying chromia-enriched layer formed.

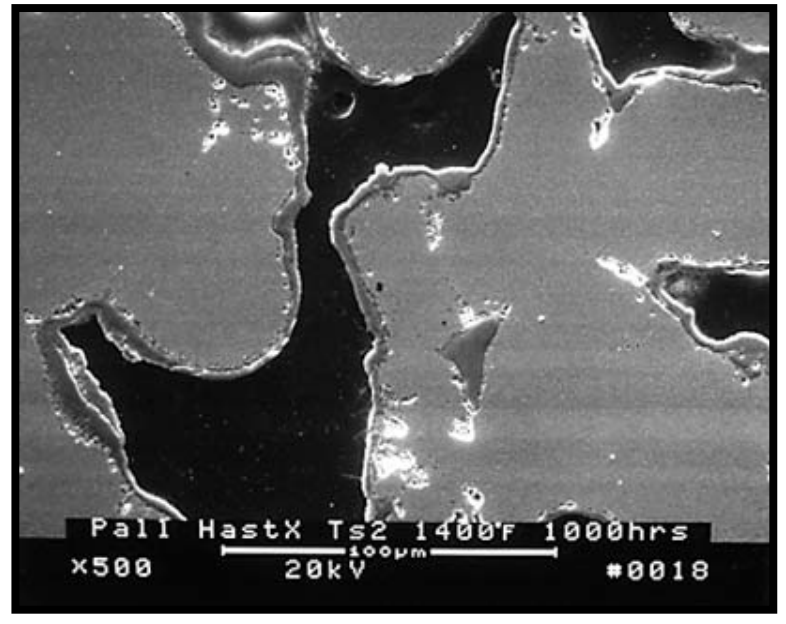

(a)

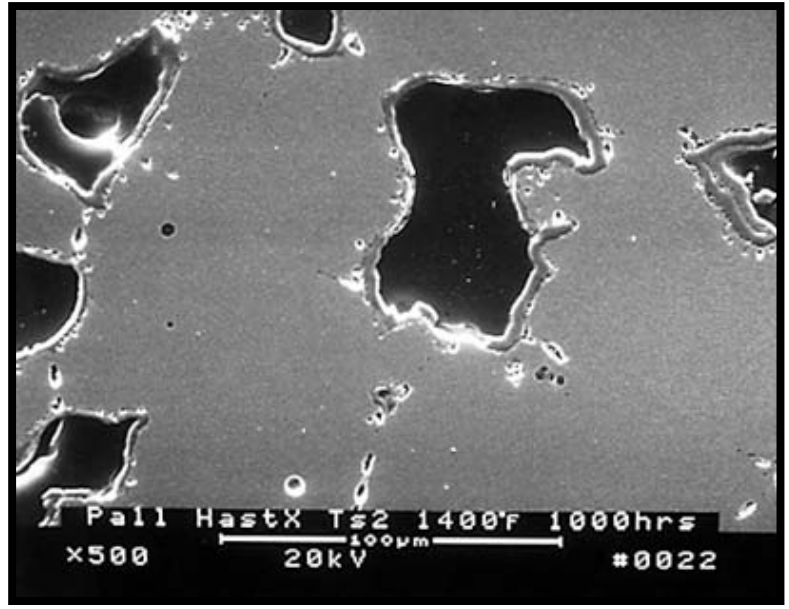

(b)

Figure 58 - Morphology of the Pall Hastelloy X filter media along the (a) o.d. surface and (b) i.d or pulse cycled surface of the filter element after 1016 hours of operation in the $760^{\circ} \mathrm{C}$ $\left(1400^{\circ} \mathrm{F}\right)$ simulated $\mathrm{PFBC}$ process gas environment. 
Although the open porosity of the Pall Hastelloy $\mathrm{X}$ filter media appeared to be retained after 259,476 , and 986 hours of exposure in the $815-840^{\circ} \mathrm{C}\left(1550-1550^{\circ} \mathrm{F}\right)$ simulated PFBC process gas environment, the thickness of the oxide layer that formed along the outer surface of the Pall Hastelloy sinter bonded particles tended to increase with extended operating time: $259 \mathrm{hrs}$ : $\sim 2.4 \mu \mathrm{m}$ on the o.d. vs $\sim 4 \mu \mathrm{m}$ on the i.d.; $476 \mathrm{hrs:} \sim 8-10 \mu \mathrm{m}$ on the o.d.; $986 \mathrm{hrs}: \sim 9 \mu \mathrm{m}$ on the o.d. vs $\sim 5-9 \mu \mathrm{m}$ on the i.d. (Figure 59 ).

Also with increased exposure time, the apparent extent of oxidation at the sinter bonded particle interface, and oxidation of the residual metal substrate directly below the external surface oxidation layer appeared to increase. Typically the composition of the external surface oxidation layer consisted of an O-Ni-Fe spinel along the outer surface of the oxide after 259 hours of simulated PFBC operation. With extended simulated PFBC exposure, the composition of the external surface oxide tended to form an $\mathrm{O}-\mathrm{Fe}-\mathrm{Ni}$ spinel. Irrespective of the exposure time period, a chromia-enriched layer formed at the oxide/base metal interface.
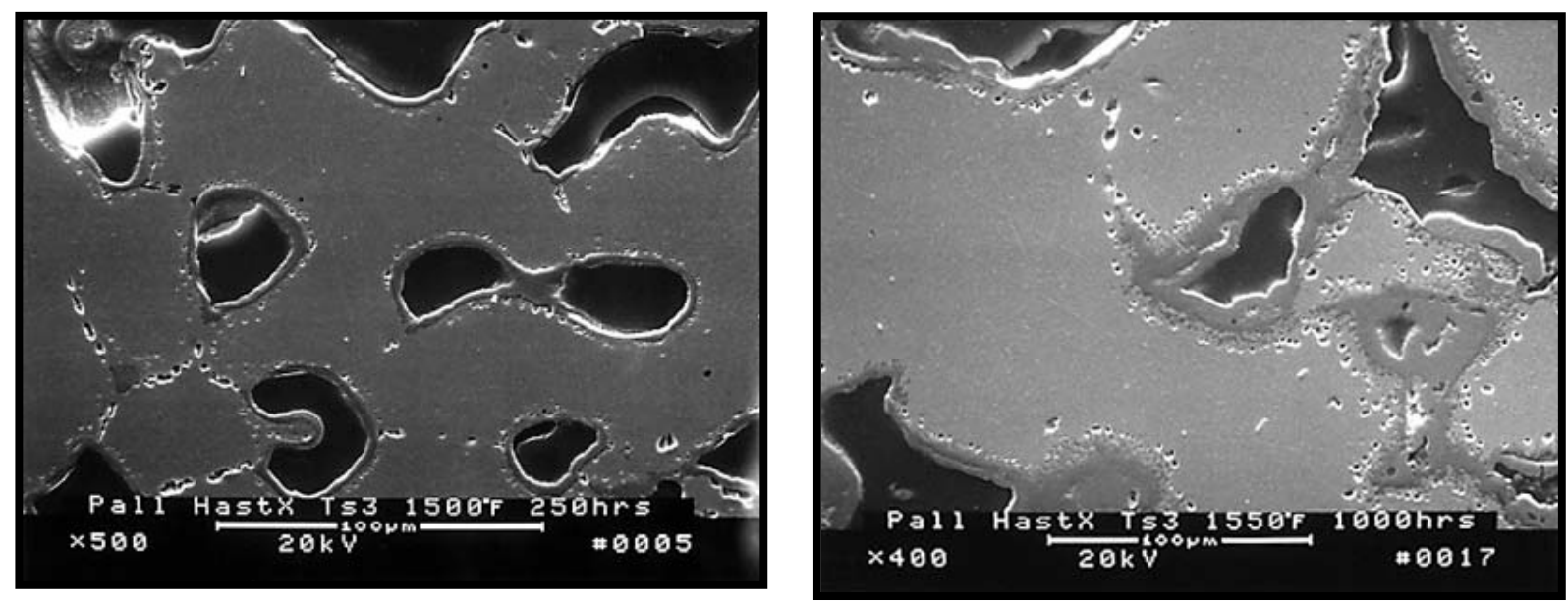

Figure 59 - Oxide formation along the outer surface of the Pall Hastelloy X sinter bonded particles after 259 and 986 hours of operation in the $815-840^{\circ} \mathrm{C}\left(1500-1550^{\circ} \mathrm{F}\right)$ simulated PFBC process gas environment.

Although open porosity existed within the Pall Hastelloy X filter media, oxidation of the sinter bonded metal particles appeared to be enhanced with extended exposure of the filter element in the $840^{\circ} \mathrm{C}\left(1550^{\circ} \mathrm{F}\right)$, sulfur-free, simulated PFBC process gas environment. After 253 hours of operation the thickness of the oxide layer that formed along the surface of the Pall Hastelloy $\mathrm{X}$ particles ranged from 2-4 $\mu \mathrm{m}$. What remained along the surface of the Hastelloy X particles that were present along the o.d. surface of the filter element was a chromia-enriched layer. Within the mid-section of the cross-sectioned filter wall, an outer layer of $\mathrm{O}-\mathrm{Ni}-\mathrm{Fe}$ spinel, and an underlying chromia-enriched layer resulted. Two distinct and separated oxide layers formed along the surface of the Hastelloy X particles that were present along the i.d. or pulse cycled surface of the simulated PFBC-exposed, Pall filter element.

After 546.5 hours of exposure in the $840^{\circ} \mathrm{C}\left(1550^{\circ} \mathrm{F}\right)$ simulated $\mathrm{PFBC}$ process gas environment, an 2.6-3.4 $\mu \mathrm{m}$ thick, chromia-enriched layer formed along the surface of the Pall Hastelloy X particles that were located along the o.d. surface of the filter element. The oxide layer that remained along the surface of the Pall Hastelloy X particles that were present along the i.d. or 
pulse cycled surface of the filter element contained cracks, implying that removal of the oxide layer formation may have occurred.

With continued exposure in the simulated PFBC environment (i.e., 1014 hours), an 16-20 $\mu \mathrm{m}$ thick oxide layer formed along the surface of the Pall Hastelloy X sinter bonded particles that were present along the o.d. surface of the filter element (Figure 60). The composition of the outer oxide layer consisted of $\mathrm{O}-\mathrm{Fe}-\mathrm{Ni}$, with a subsurface chromia-enriched layer. Significant crack formations were evident along the residual $\sim 3 \mu \mathrm{m}$ thick oxide layer that remained along the external surface of the particles that were present along the i.d. or pulse cycled surface of the Pall Hastelloy X filter element.

Internal oxidation along the base metal interface, as well as along the sinter bonds that formed between adjacent particles were clearly observed after 253 hours of exposure in the $840^{\circ} \mathrm{C}$ $\left(1550^{\circ} \mathrm{F}\right)$ simulated $\mathrm{PFBC}$ process gas environment. Internal oxidation of the Pall Hastelloy $\mathrm{X}$ particles was more pronounced with extended simulated PFBC exposure time.

Based on the results generated during simulated PFBC testing, it appeared that pulse cycling reduced the adherence or integrity of the oxide formation to remain attached to the Pall Hastelloy X base metal substrate (Figure 61).
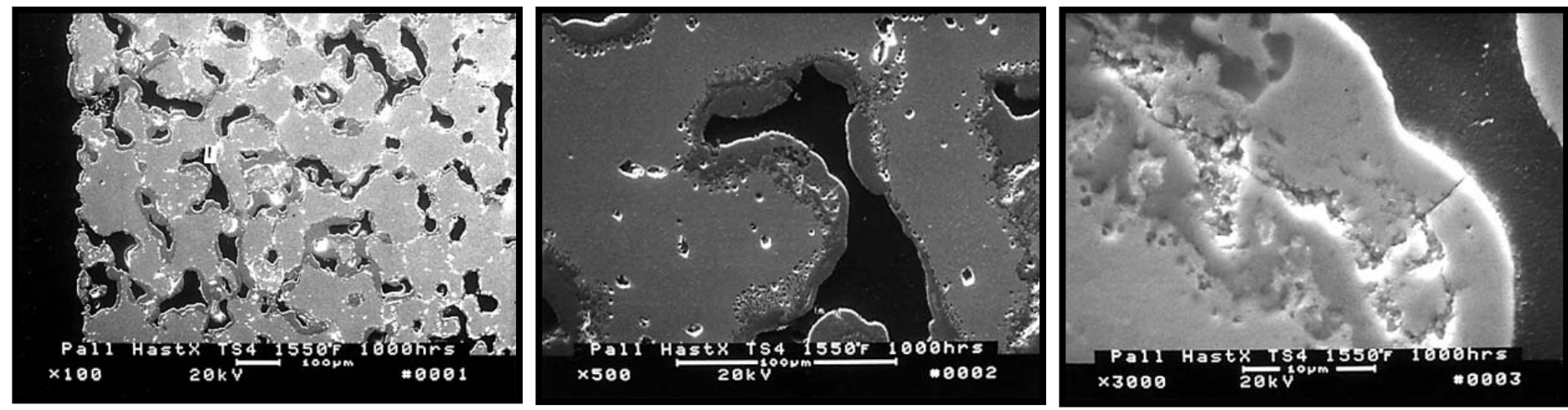

Figure 60 - Morphology of the Pall Hastelloy X filter media after 1014 hours of operation in the $840^{\circ} \mathrm{C}\left(1550^{\circ} \mathrm{F}\right)$ simulated $\mathrm{PFBC}$ process gas environment.

\subsubsection{Impact of Gas Phase Alkali}

The open porosity of the Pall Hastelloy $\mathrm{X}$ sinter bonded particle matrix was generally retained after 225 and 496 hours of exposure to the $840^{\circ} \mathrm{C}\left(1550^{\circ} \mathrm{F}\right)$ simulated PFBC process gas environment that contained gas phase sulfur and alkali. Surface oxidation of the contained particles, oxidation of the base metal at the oxide/metal interface, and oxidation along the sinter bonds between adjacent Hastelloy X particles were evident. 

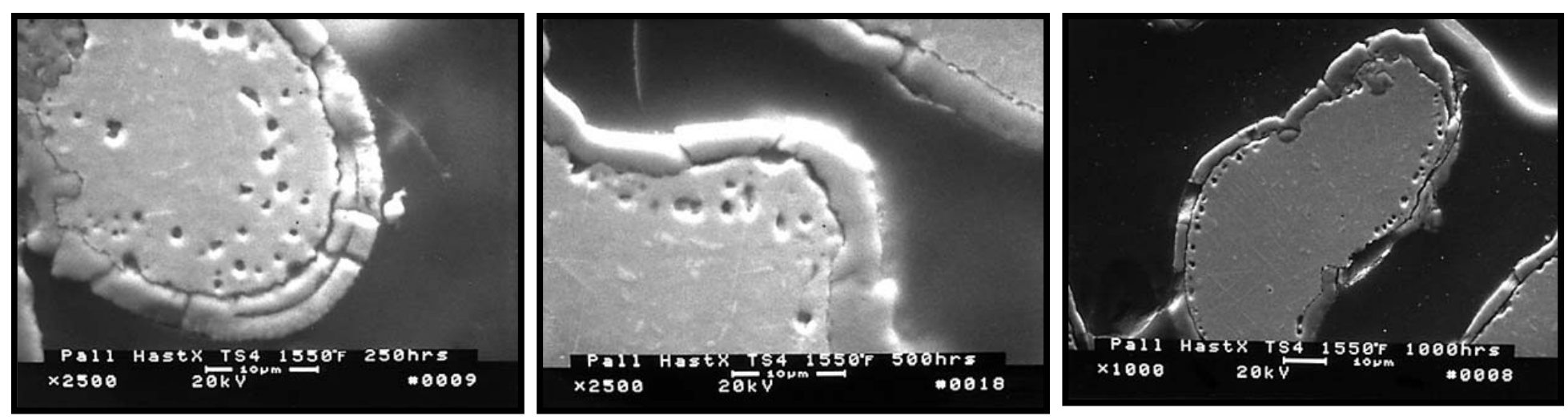

Figure 61 - Micrographs illustrating the formation of cracks and separation of the oxide layers along the outer surface of the sinter bonded Pall Hastelloy X particles after 253, 546.5, and 1014 hours of exposure in a sulfur-free simulated PFBC process gas environment.

Typically the oxide formation that resulted along the surface of the sinter bonded Hastelloy $\mathrm{X}$ particles existed as a continuous bi-layer structure. The composition of the external oxide surface was enriched with an O-Fe-Ni spinel ( 2.5-8.8 $\mu \mathrm{m}$ thick after 225 hours; $~ 6.5-8.5 \mu \mathrm{m}$ thick after 498 hours). An underlying chromia-enriched layer formed along the base metal interface ( 1.8-5 $\mu \mathrm{m}$ after 225 hours; $\sim 1.6-4 \mu \mathrm{m}$ after 496 hours).

Near the center of the cross-sectioned filter wall, and particularly along the i.d. or pulse cycled surface of the filter element, crack formations were readily evident through the thickness of the residual oxide formation. Where present, the thickness of the residual oxide formation was estimated to be $\sim 2-5 \mu \mathrm{m}$, and was identified to be chromia-enriched. Removal of an external oxide layer which separated from the chromia-enriched surface was expected to have occurred after 496 hours of operation along the pulse cycled surface of the $840^{\circ} \mathrm{C}\left(1550^{\circ} \mathrm{F}\right)$, gas phase sulfur and alkali-containing, simulated PFBC-exposed, Pall Hastelloy X filter media.

\subsection{Mott Inconel 600 - Ni Bal, $15.5 \% \mathrm{Cr}, 8 \% \mathrm{Fe}, 0.3 \% \mathrm{Mn}, 0.2 \% \mathrm{Si}, \mathbf{0 . 2 \%} \mathrm{Al}, 0.2 \% \mathrm{Ti}$}

\subsubsection{Simulated PFBC Operation}

In contrast to the U.S. Filter/Fluid Dynamics (USF) Inconel 600 filter media, the $\sim 3.5 \mathrm{~mm}$ thick monolithic Mott filter wall consisted of sinter bonded $\sim 50 \mu \mathrm{m} \mathrm{x} \sim 100 \mu \mathrm{m}$ particles. A more open or porous structure was formed along both o.d. and i.d. surfaces of the filter matrix, with densification resulting along the mid-section of the filtration media. The open porosity of the Mott Inconel 600 filtration media appeared to have been retained after 242 and 500 hours of operation in the $650^{\circ} \mathrm{C}\left(1200^{\circ} \mathrm{F}\right)$ simulated PFBC process gas environment (Figure 62).

After 242 hours of exposure at $650^{\circ} \mathrm{C}\left(1200^{\circ} \mathrm{F}\right)$ in the simulated $\mathrm{PFBC}$ operating environment, the Mott Inconel 600 filter media underwent oxidation leading to the formation of an external $\sim 3-3.5 \mu \mathrm{m}$ thick nickel chromate iron-enriched scale, and an underlying $\sim 4.5 \mu \mathrm{m}$ thick nickel oxide or nickel chromate-enriched layer, along the o.d. surface of the filter element (Figure 63). The thickness of the oxide coating was not uniformly distributed around the individual sinter bonded Inconel 600 particles, but appeared to preferentially result along the surface that was 
directly contacted with the simulated PFBC process gas stream. Along the densely packed midsection of the Mott Inconel 600 filter wall, limited oxidation was apparent. Along the i.d. surface of the Mott filter media, an $\sim 3.2 \mu \mathrm{m}$ thick oxide scale was observed to have formed intermittently along the surface of the Inconel 600 sinter bonded particles.

Although intermittently identified, the thickness of the oxide scale which formed along the outer surface of the 500 hour, $650^{\circ} \mathrm{C}\left(1200^{\circ} \mathrm{F}\right)$ simulated PFBC-exposed, sinter bonded, Inconel 600 particles ranged from $\sim 1-2 \mu \mathrm{m}$ along the o.d. surface, to $\sim 1 \mu \mathrm{m}$ along the denser mid-section, to $\sim 2-4 \mu \mathrm{m}$ along the i.d. surface of the filter element.
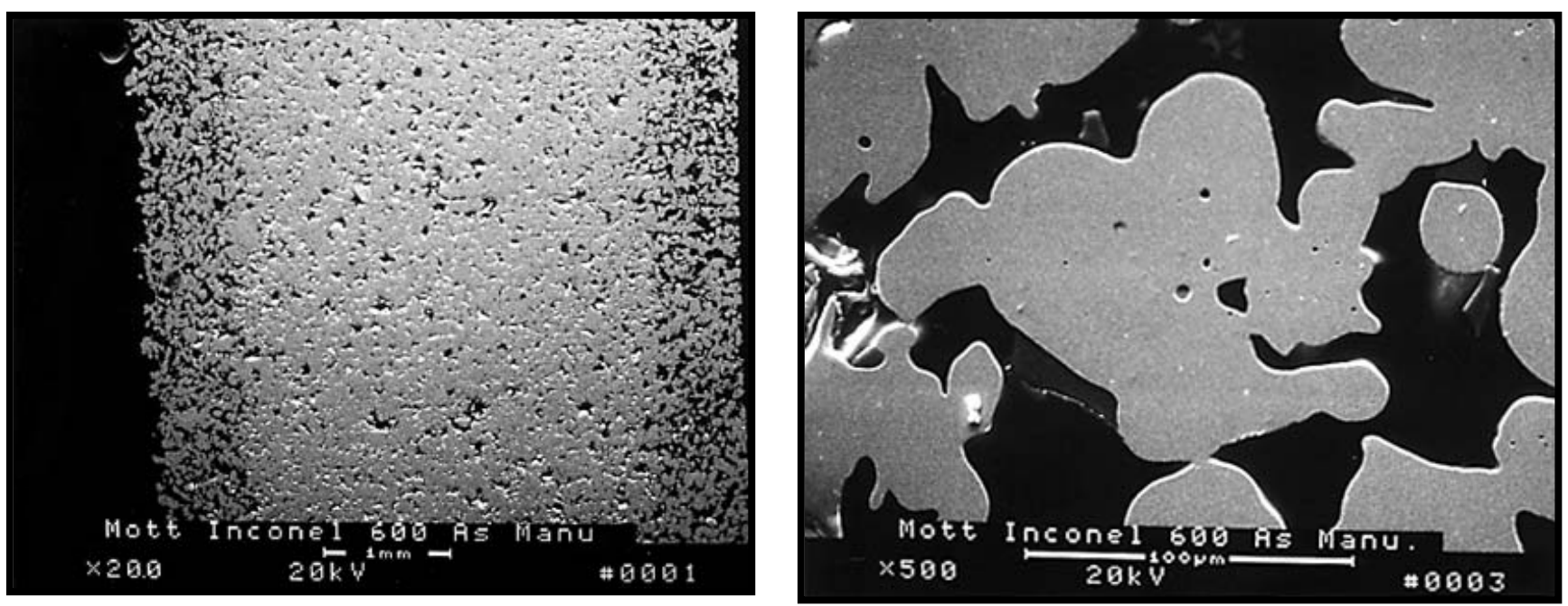

Figure 62 - Morphology of the as-manufactured Mott Inconel 600 filtration media.

Although oxidation occurred throughout the Mott Inconel 600 filter media after 258-1016 hours of operation in the $760^{\circ} \mathrm{C}\left(1400^{\circ} \mathrm{F}\right)$ simulated $\mathrm{PFBC}$ process gas environment, open porosity was retained throughout the cross-sectioned, monolithic, sinter bonded particle, filter wall. Typically the oxide layer that formed along the outer surface of the Mott Inconel 600 sinter bonded particles consisted of an external nickel oxide layer, an underlying nickel chromate layer, and a chromia-enriched layer adjacent to the base metal substrate (Figure 64).

Crack formations and debonding of localized areas of the oxide were observed within the Mott Inconel 600 filter media after 258-1016 hours of operation. Where retained, the thickness of the oxide was $\sim 3.3 \mu \mathrm{m}$ after 258 hours of simulated PFBC exposure; $\sim 6 \mu \mathrm{m}$ after 524.5 hours of simulated PFBC exposure; and between 4 and $11.7 \mu \mathrm{m}$ after 1016 hours of simulated PFBC exposure. Internal oxidation and oxidation along the sinter bonds between adjacent particles within the Mott Inconel 600 filter media were also evident.

The open porosity of the Mott Inconel 600 filter media similarly was retained after 986 hours of operation in the $815-840^{\circ} \mathrm{C}\left(1500-1550^{\circ} \mathrm{F}\right)$ simulated PFBC process gas environment. Typically oxidation resulted along the outer surface of the sinter bonded Inconel 600 particles. More extensive oxidation of the filtration media appeared to have resulted along the outer and i.d. or pulse cycled surfaces of the filter element. General trends indicative of oxide growth along the external surface of the sinter bonded Inconel 600 particles as a function of time were not apparent. 

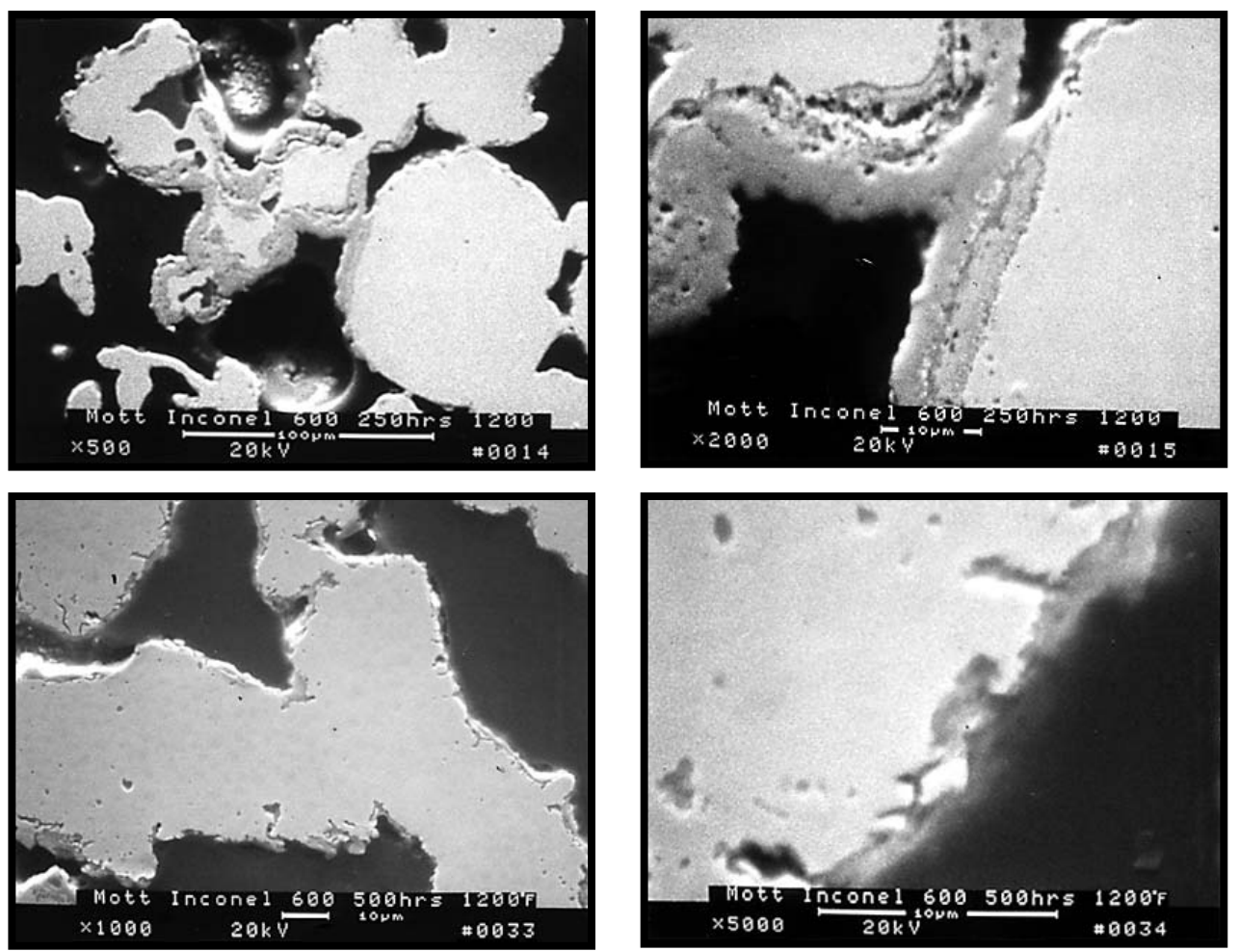

Figure 63 - Morphology of the Mott Inconel 600 filtration media after 242 and 500 hours of operation in the $650^{\circ} \mathrm{C}\left(1200^{\circ} \mathrm{F}\right)$ simulated PFBC process gas environment.
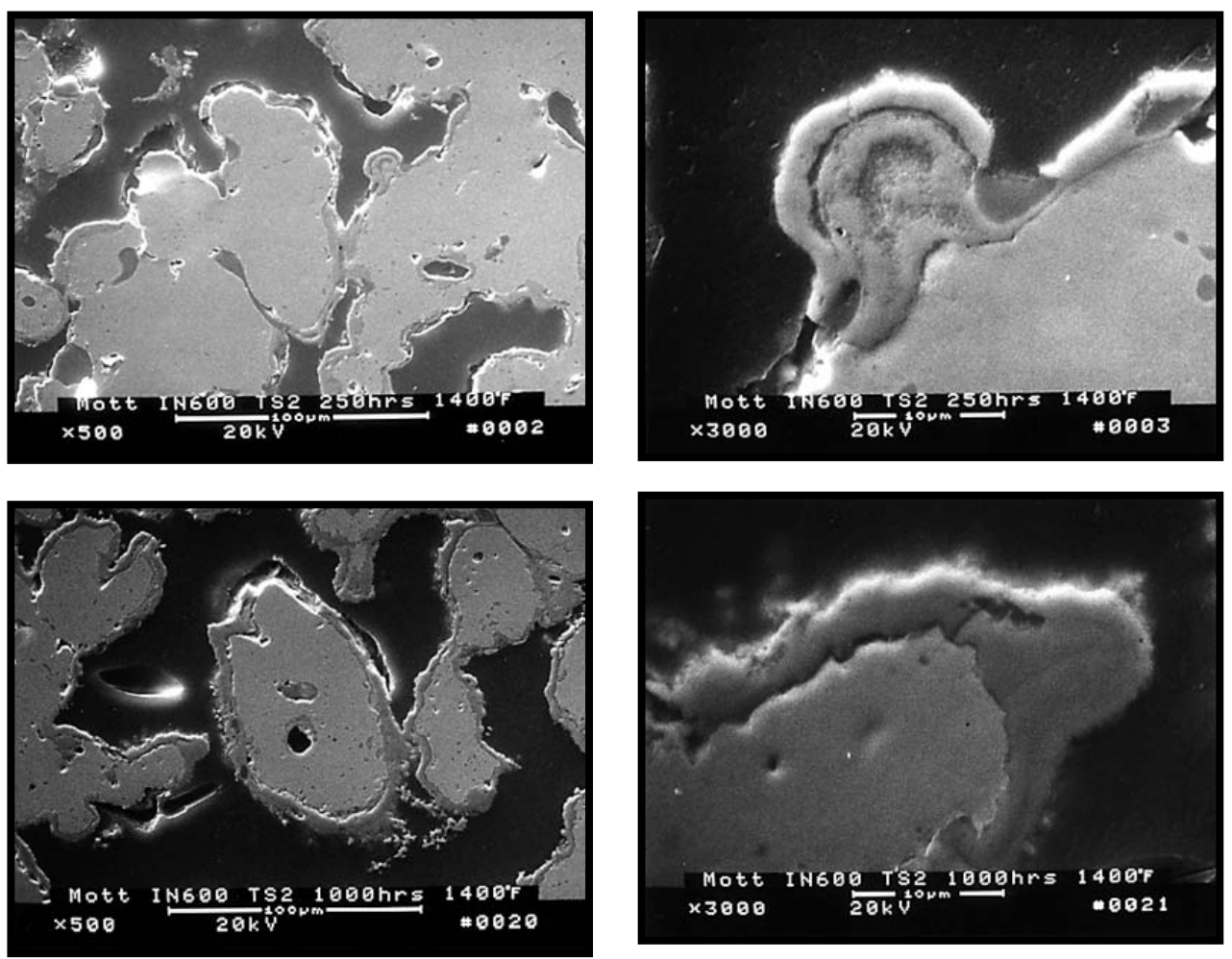

Figure 64 - Morphology of the Mott Inconel 600 filtration media after 258 and 1016 hours of operation in the $760^{\circ} \mathrm{C}\left(1400^{\circ} \mathrm{F}\right)$ simulated PFBC process gas environment. 
The thickness of the oxide ranged between $\sim 8.3$ and $\sim 16.6 \mu \mathrm{m}$ after 259 hours of exposure at $815^{\circ} \mathrm{C}$ $\left(1500^{\circ} \mathrm{F}\right)$; between $\sim 1.6$ and $\sim 7.5 \mu \mathrm{m}$ after 476 hours of exposure at $815-840^{\circ} \mathrm{C}\left(1500-1550^{\circ} \mathrm{F}\right)$; and between $\sim 4.6$ and $10 \mu \mathrm{m}$ after 986 hours of exposure at $815-840^{\circ} \mathrm{C}\left(1500-1550^{\circ} \mathrm{F}\right)$ (Figure 65). Crack formations within the external oxide layer, as well as internal oxidation within the residual base metal of the sinter bonded particles were observed.

Typically nickel oxide resulted along the outer surface of the oxide layer. Beneath this layer, a nickel chromate or O-Fe-Ni- phase formed. A subsurface chromia-enriched layer was also observed. At the base metal/oxide interface, nickel oxide was seen to be present within the 986 hour, $815-840^{\circ} \mathrm{C}\left(1500-1550^{\circ} \mathrm{F}\right)$, simulated PFBC-exposed, Mott Inconel 600 filter media.
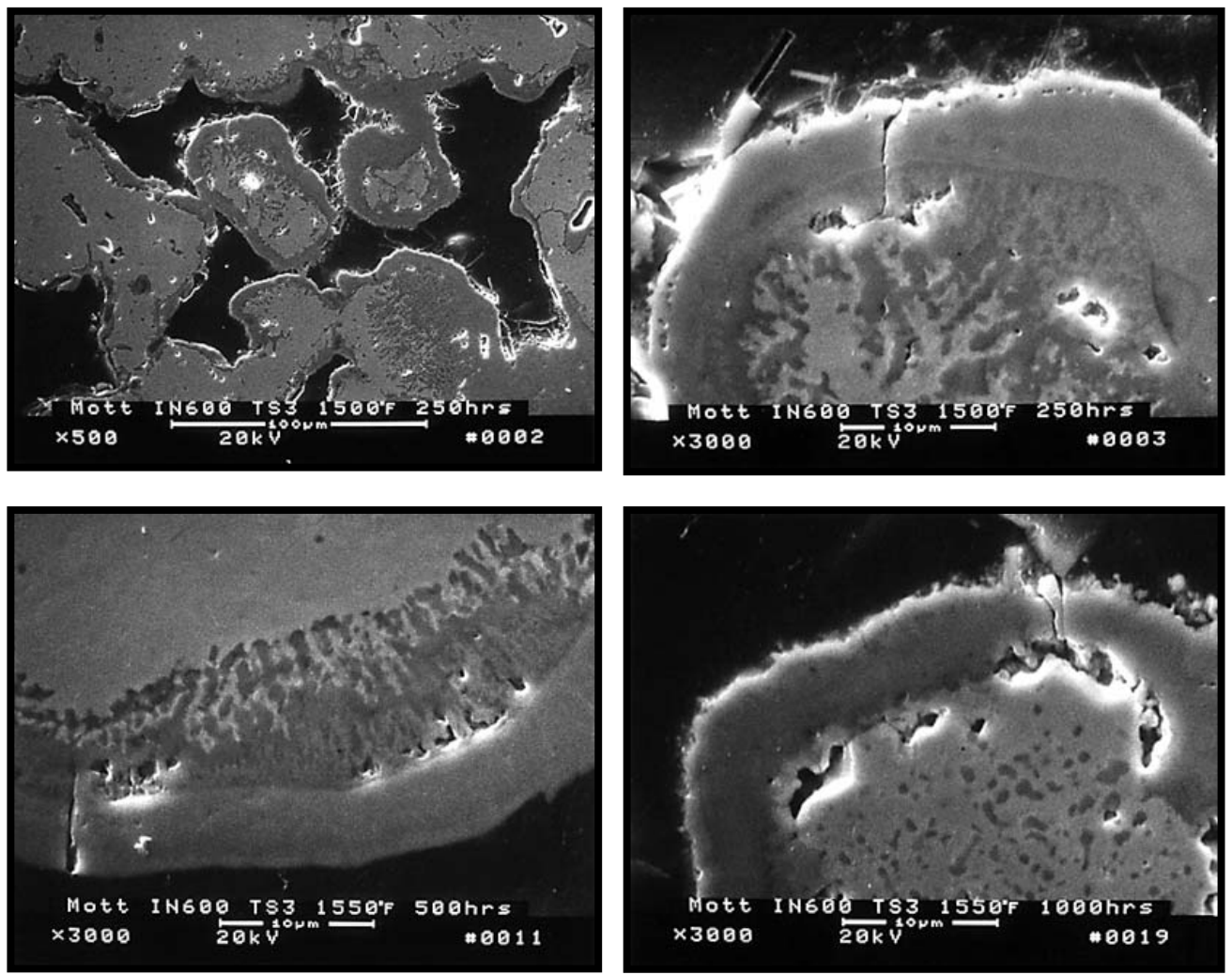

Figure 65 - Morphology of the Mott Inconel 600 filtration media after 259 and 986 hours of operation in the $815-840^{\circ} \mathrm{C}\left(1500-1550^{\circ} \mathrm{F}\right)$ simulated $\mathrm{PFBC}$ process gas environment.

Extensive oxidation resulted along the outer surface of the sinter bonded Inconel 600 particles after $253-1014$ hours of operation in the $840^{\circ} \mathrm{C}\left(1550^{\circ} \mathrm{F}\right)$, sulfur-free, simulated PFBC process gas environment. With the exception of localized areas, the open porosity of the filter media was retained.

An internal oxidation zone within the sinter bonded Inconel 600 particles was typically present in localized areas beneath the multi-phase external surface oxide formation (Figure 66). From the external oxide surface to the base metal interface, the composition of the oxide consisted of

- Nickel/low chromium oxide, nickel oxide, nickel chromate spinel, and chromia after 253 hours of operation. 
- Nickel chromate, O-Ni-Fe, O-Ni-Cr, and chromia after 546.5 hours of operation.

- Nickel oxide, $\mathrm{O}-\mathrm{Ni}(\mathrm{Fe}), \mathrm{O}-\mathrm{Cr}-\mathrm{Ni}$, and chromia after 1014 hours of operation.

Along the outer surface of the cross-sectioned filter element, the thickness of the external oxide layer was $\sim 7.2-17.2 \mu \mathrm{m}$. Internal oxidation within the sinter bonded particles penetrated to depths of $\sim 4.8-7.2 \mu \mathrm{m}$. Along the i.d. or pulse cycled surface of the Mott Inconel 600 filter element, the thickness of the external oxide was $\sim 8.8 \mu \mathrm{m}$. The thickness of the internal oxidation zone ranged between $\sim 12-14 \mu \mathrm{m}$ within the sinter bonded Inconel 600 particles.

Along the i.d. or pulse cycled surface of the Inconel 600 filter media, internal oxidation within the sinter bonded particles, as well as along sinter bonds between adjacent particles were more frequently observed than along the mid-section or outer surface of the simulated PFBCexposed Mott Inconel 600 filter element.
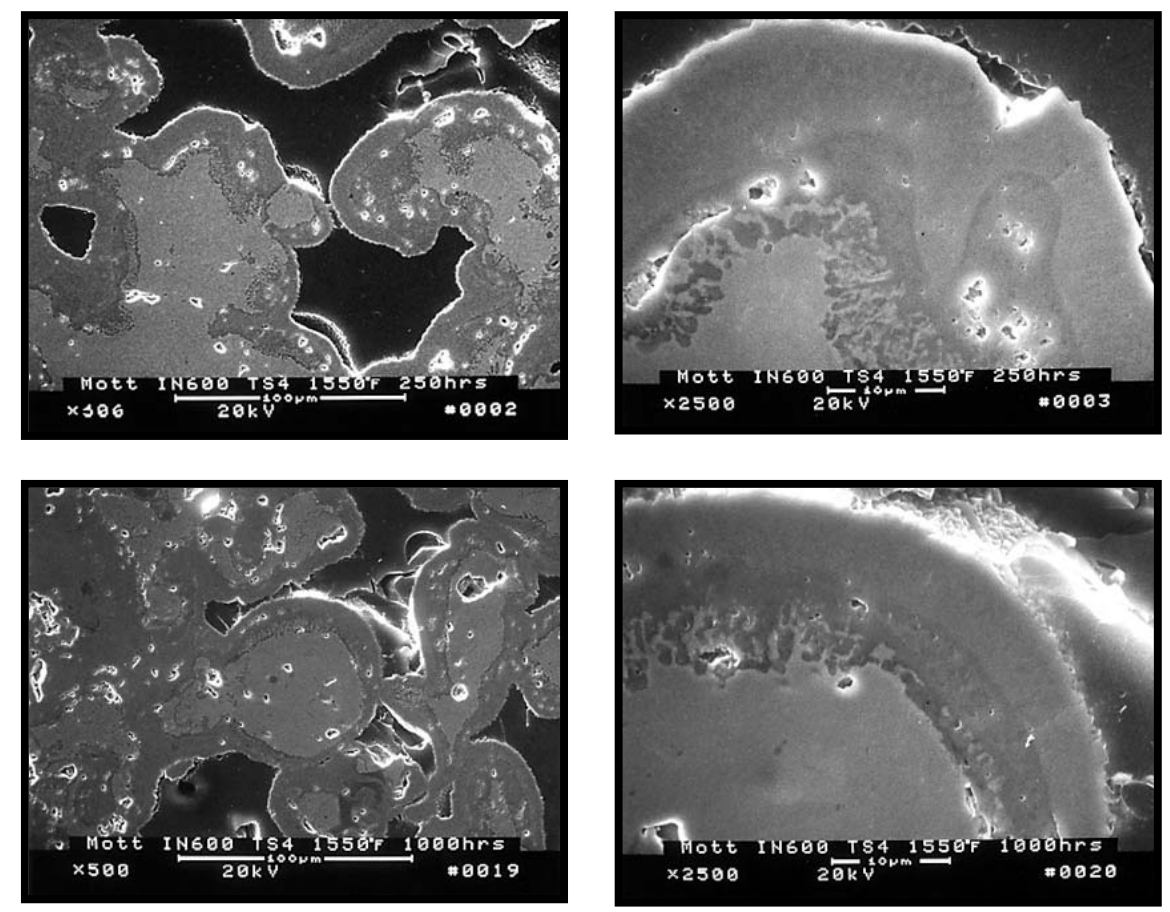

Figure 66 - Morphology of the Mott Inconel 600 filtration media after 253 and 1014 hours of operation in the $840^{\circ} \mathrm{C}\left(1550^{\circ} \mathrm{F}\right)$, sulfur-free, simulated PFBC process gas environment.

\subsubsection{Impact of Gas Phase Alkali}

The open porosity of the Mott sinter bonded Inconel 600 filtration media appeared to generally be retained after $225-496$ hours of exposure in the $840^{\circ} \mathrm{C}\left(1550^{\circ} \mathrm{F}\right)$ simulated $\mathrm{PFBC}$ process gas environment that contained gas phase sulfur and alkali (Figure 67). Where pore closure tended to occur, primarily along the outer surface of the filter element, internal oxidation of the base metal media was observed. After 225 hours in the $840^{\circ} \mathrm{C}\left(1550^{\circ} \mathrm{F}\right)$ simulated PFBC process gas environment, internal oxidation penetrated to depths of $\sim 2 \mu \mathrm{m}$ into the base metal substrate. After 496 hours, depth of penetration of the internal oxide reached $\sim 10 \mu \mathrm{m}$. 
After 496 hours of operation in the $840^{\circ} \mathrm{C}\left(1550^{\circ} \mathrm{F}\right)$ gas phase sulfur and alkali-containing simulated PFBC process gas environment, chromia-enriched dendritic formations were observed to extend from the surface of the Mott Inconel 600 sinter bonded particles that were present along the mid-section of the filter wall (Figure 68 ). Beneath the dendritic formations, an $\sim 6 \mu \mathrm{m}$ thick $\mathrm{Cr}$-Ni$\mathrm{O}$ phase formed.

Along the i.d. or pulse cycled surface of the filter media, crack formations within and localized removal of the oxide layer were evident. In contrast to the outer surface of the filter media, internal oxidation of the Mott Inconel 600 sinter bonded particles was not observed along the i.d. or pulse cycled surface of the Mott Inconel 600 filter media after 225-496 hours of operation.
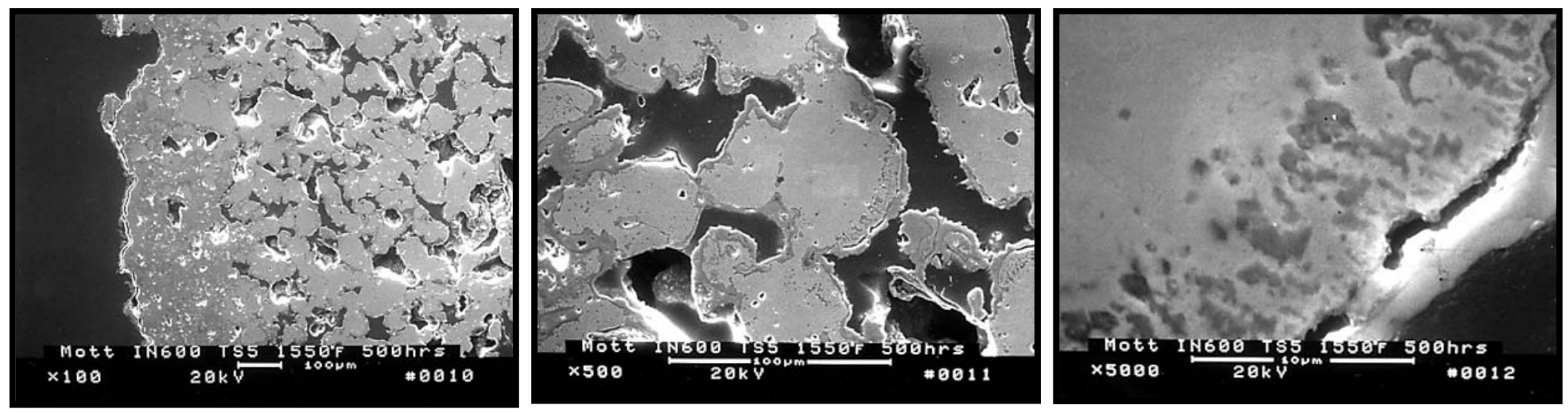

Figure 67 - Morphology of the Mott Inconel 600 filtration media after 225 and 496 hours of operation in the $840^{\circ} \mathrm{C}\left(1550^{\circ} \mathrm{F}\right)$ simulated $\mathrm{PFBC}$ process gas environment that contained gas phase sulfur and alkali
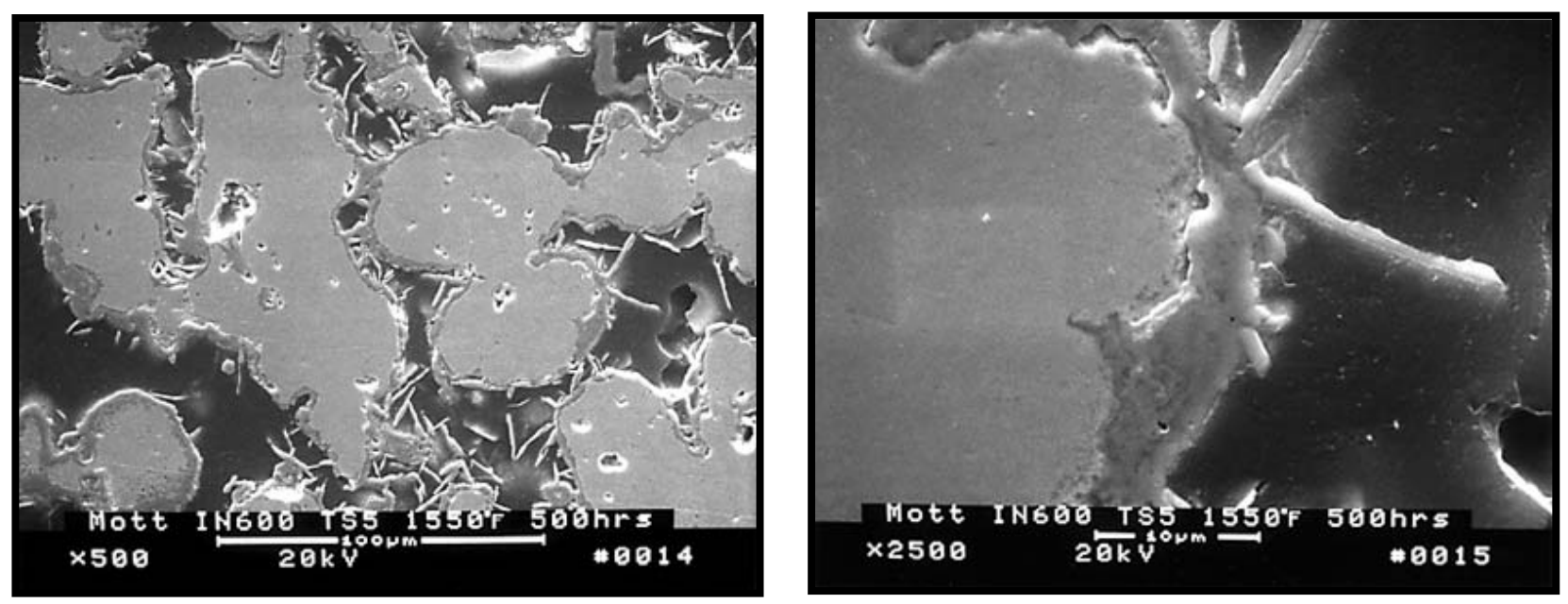

Figure 68 - Micrographs illustrating the morphology of the cross-sectioned Mott Inconel 600 media along the mid-section of the filter wall after 496 hours of exposure in the $840^{\circ} \mathrm{C}$ $\left(1550^{\circ} \mathrm{F}\right)$ simulated $\mathrm{PFBC}$ process gas environment containing gas phase sulfur and alkali. 


\subsection{Fairey Microfiltrex Fecralloy}

\subsubsection{Simulated PFBC Operation}

The as-manufactured Fairey Microfiltrex CCTFTM filter matrix consisted of a filtration mat layer that was surrounded by an open wire mesh screen along its o.d. surface, and was structurally supported along its i.d. surface via a perforated metal cylindrical section. When sectioned, the porous, fibrous, metal media filtration mat was easily removed. As shown in Figure 69, the $\sim 0.5 \mathrm{~mm}$ thick Fecralloy filtration media consisted of a porous, sinter bonded, fibrous outer area, and a more densified, underlying, porous filtration area. The cross-sectional diameter of the Fairey Microfiltrex CCTFTM fibers contained in the outer surface filtration mat layer was $\sim 17-30 \mu \mathrm{m}$, while the cross-sectioned diameter of the underlying filtration mat fibers (i.e., mid-section to i.d.) was $\sim 8-10 \mu \mathrm{m}$.

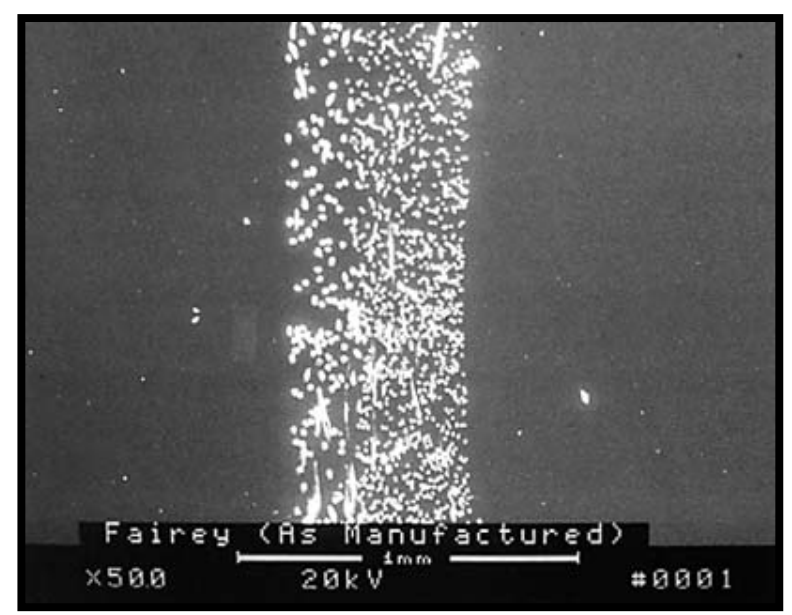

Figure 69 - Morphology of the as-manufactured Fairey Microfiltrex filtration media.

The open porosity of the Fairey Microfiltrex Fecralloy CCFT ${ }^{\mathrm{TM}}$ filtration matrix was retained after 242 and 500 hours of operation in the $650^{\circ} \mathrm{C}\left(1200^{\circ} \mathrm{F}\right)$ simulated PFBC environment. Enrichment of aluminum along the external surface of the filtration mat fibers tended to occur (Figure 70). Oxygen was also detected along the external surface of the filtration mat fibers, implying the formation of alumina or a precursor alumina phase.

In contrast to the filtration media that was used for testing in the $650^{\circ} \mathrm{C}\left(1200^{\circ} \mathrm{F}\right)$ simulated PFBC environment, the outer surface of the Fairey Microfiltrex media that was subjected to the $760^{\circ} \mathrm{C}\left(1400^{\circ} \mathrm{F}\right)$ simulated PFBC environment consisted of the denser layer of $\sim 9-12 \mu \mathrm{m}$ (crosssectional diameter) sinter bonded Fecralloy fibers. Along the inner surface of the filtration media, the more open, $\sim 15-30 \mu \mathrm{m}$ (cross-sectional diameter) sinter bonded fibrous matrix was used.

Although the open porosity of the Fairey Microfiltrex filtration media was retained after 258-1016 hours of operation in the $760^{\circ} \mathrm{C}\left(1400^{\circ} \mathrm{F}\right)$ simulated PFBC process gas environment, both fiber-containing layers experienced surface oxidation (Figure 71). Initially an iron-oxide-enriched, minor chromium-aluminum layer formed along the surface of the finer fibers in the outer surface layer of the Fairey Microfiltrex filtration media. With time, the formation of an underlying iron oxide/alumina-enriched subsurface layer was initiated. After 1016 hours of exposure in the $760^{\circ} \mathrm{C}$ $\left(1400^{\circ} \mathrm{F}\right)$ simulated PFBC environment, the adherent, encapsulating oxide layer consisted solely of 


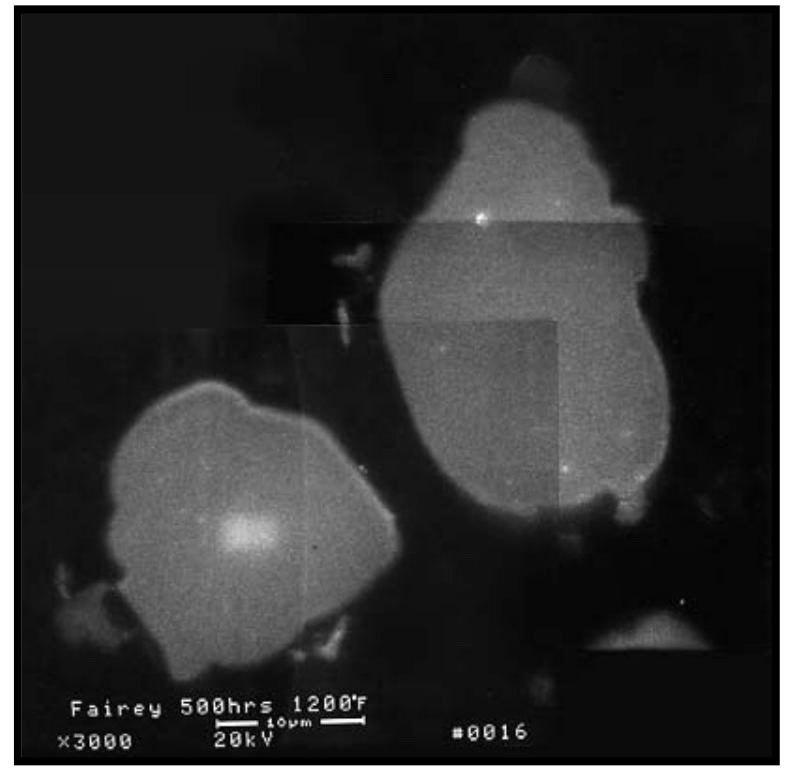

(a)

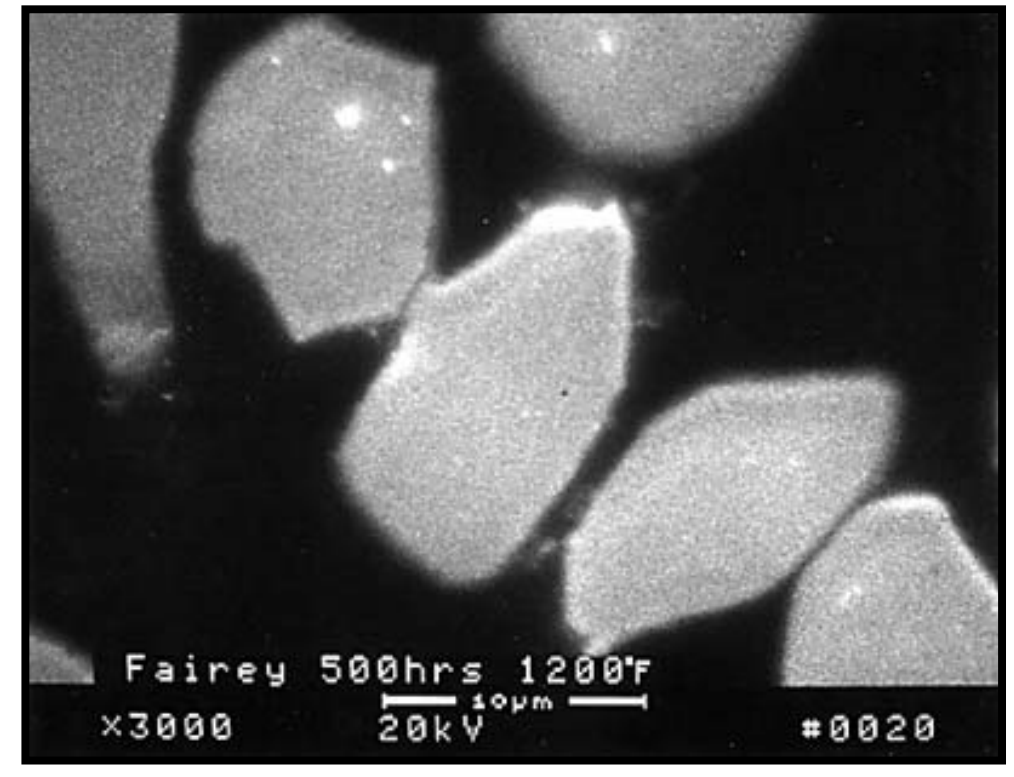

(b)

Figure 70 - Morphology of the sinter bonded Fairey Microfiltrex Fecralloy fibers after 500 hours of operation in the $650^{\circ} \mathrm{C}\left(1200^{\circ} \mathrm{F}\right)$ simulated PFBC process gas environment. (a) Outer surface fibers; (b) Inner surface fibers.
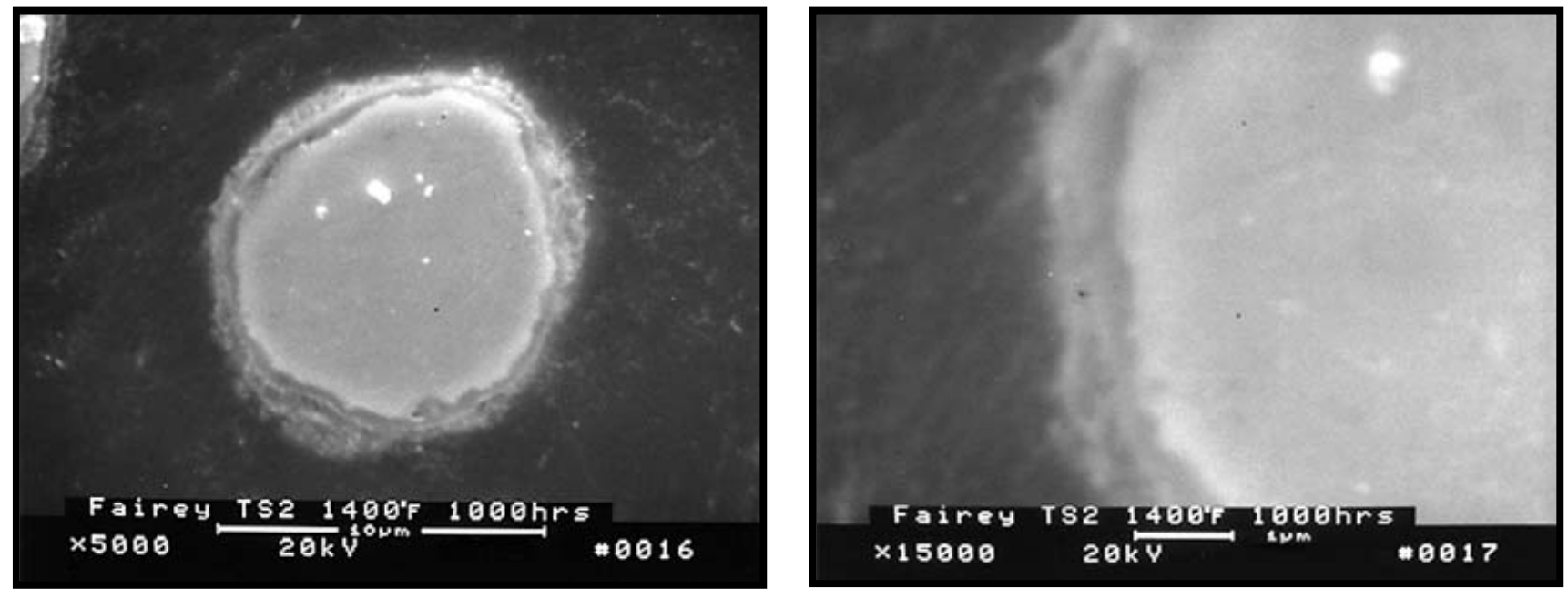

Figure 71 - Microstructure of the Fairey Microfiltrex Fecralloy fibers after 1016 hours of operation in the $760^{\circ} \mathrm{C}\left(1400^{\circ} \mathrm{F}\right)$ simulated $\mathrm{PFBC}$ process gas environment. 
iron oxide/alumina (i.e., iron aluminate). The thickness of the resulting oxide tended to be constant as a function of time (i.e., $\sim 0.7 \mu \mathrm{m}$ ).

In contrast, the composition of the oxide layer that formed along the outer surface of the coarser fibers contained within the inner section of the Fairey Microfiltrex filtration media was initially iron oxide/alumina (i.e., iron aluminate). With continued exposure time, the concentration of iron decreased, while the concentration of aluminum increased. The thickness of the oxide formed along the surface of the coarser fibers ranged from $\sim 0.3-0.7 \mu \mathrm{m}$, tending to increase with extended exposure time. Notably, the thickness of the oxide along the surface of the coarse fibers tended to be less than that formed along the surface of the finer fibers contained along the outer section of the Fairey Microfiltrex filtration mat.

The open porosity of the Fairey Microfiltrex Fecralloy filtration media was retained after $259-986$ hours of operation in the $815-840^{\circ} \mathrm{C}\left(1500-1550^{\circ} \mathrm{F}\right)$ simulated $\mathrm{PFBC}$ process gas environment. Both fine and coarse fibers experienced surface oxidation (Figure 72). Along the outer surface of the finer fibers, an $\sim 0.3-0.5 \mu \mathrm{m}$ thick oxide layer resulted. The encapsulating layer principally contained oxides of iron and aluminum. After 259 hours of operation in the $815^{\circ} \mathrm{C}$ $\left(1500^{\circ} \mathrm{F}\right)$ simulated PFBC environment, the concentration of iron-to-aluminum was equivalent. With extended time in the $840^{\circ} \mathrm{C}\left(1550^{\circ} \mathrm{F}\right)$ simulated $\mathrm{PFBC}$ environment, the concentration of alumina exceeded that of iron (oxide).

Along the outer surface of the coarser fibers, an $\sim 0.2-0.6 \mu \mathrm{m}$ thick oxide layer resulted. Once again, the encapsulating layer principally contained oxides of iron and aluminum. A slightly higher ratio of aluminum-to-iron was identified in the oxide layer after 259 hours of exposure in the $815^{\circ} \mathrm{C}\left(1500^{\circ} \mathrm{F}\right)$ simulated $\mathrm{PFBC}$ environment. With extended time at $840^{\circ} \mathrm{C}\left(1550^{\circ} \mathrm{F}\right)$, alumina was seen to form as the primary phase.

The open porosity of the Microfiltrex filtration media was similarly retained after 253-1014 hours of operation in the $840^{\circ} \mathrm{C}\left(1550^{\circ} \mathrm{F}\right)$, sulfur-free, simulated PFBC process gas environment. Along the outer surface of the finer fibers, an $\sim 0.2-0.5 \mu \mathrm{m}$ thick oxide layer resulted. The encapsulating layer principally contained oxides of iron and aluminum. After 253 hours of operation, the concentration of iron-to-aluminum was nearly equivalent. With extended time, the concentration of alumina exceeded that of iron (oxide).

Along the outer surface of the coarser fibers, an $\sim 0.2-1.5 \mu \mathrm{m}$ thick oxide layer resulted. Once again, the encapsulating layer principally consisted of alumina and iron oxide.

\subsubsection{Impact of Gas Phase Alkali}

In the presence of gas phase sulfur and alkali, oxidation and densification of the Fairey Microfiltrex fine Fecralloy fibers resulted after 225 hours of operation in the $840^{\circ} \mathrm{C}\left(1550^{\circ} \mathrm{F}\right)$ simulated PFBC process gas environment. Due to extensive oxidation and densification along the outer surface of the filtration mat, gas flow permeability was restricted through the filtration media (Figure 73). Iron oxide phases primarily resulted along the surface of the extensively oxidized, fine Fecralloy fibers. Within the interior of the filtration mat where fine fibers did not experience densification and/or agglomeration, an iron oxide-enriched/alumina layer formed, encapsulating the outer surface of the contained fine Fecralloy fibers.

In contrast, an alumina-enriched/iron oxide layer formed along the outer surface of the coarse Fecralloy fibers after 225 hours of exposure in the $840^{\circ} \mathrm{C}\left(1550^{\circ} \mathrm{F}\right)$ simulated $\mathrm{PFBC}$ operating environment (Figure 74). 

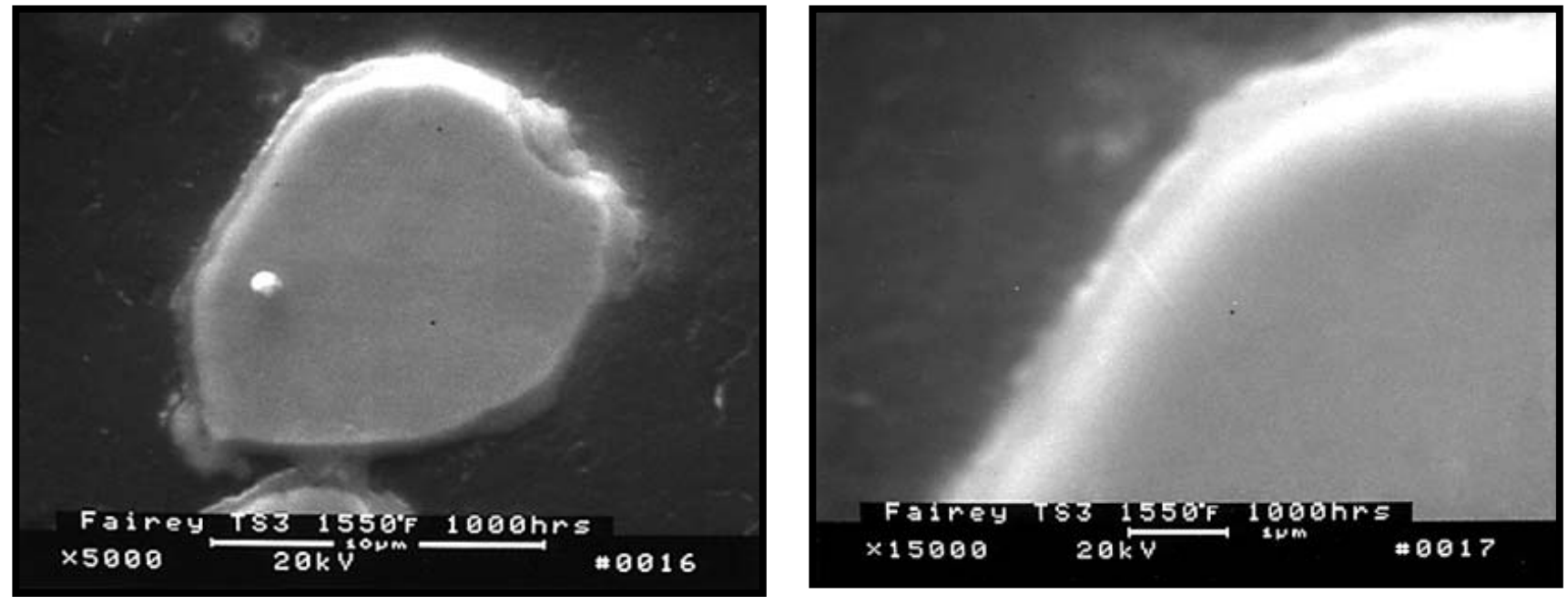

Figure 72 - Microstructure of the Fairey Microfiltrex Fecralloy fibers after 986 hours of operation in the $815-840^{\circ} \mathrm{C}\left(1500-1550^{\circ} \mathrm{F}\right)$ simulated $\mathrm{PFBC}$ process gas environment.
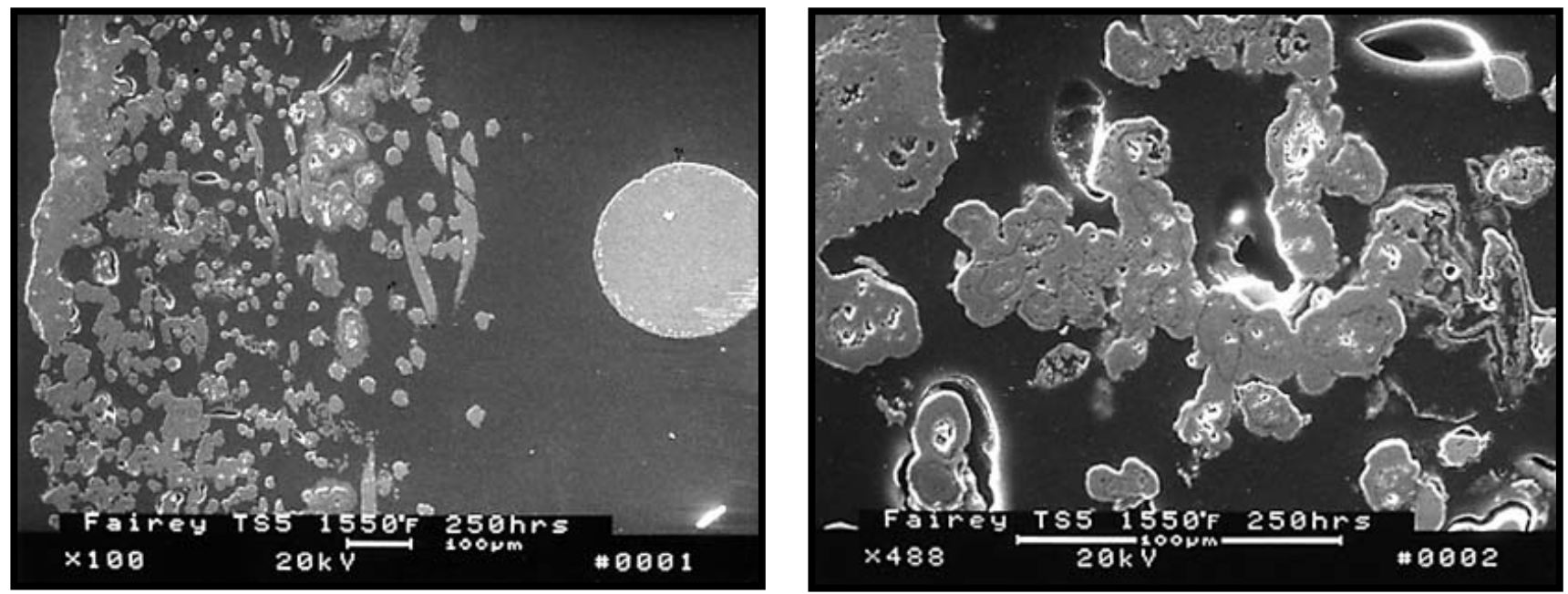

Figure 73 - Densification of the outer surface of the Fairey Microfiltrex filter element section that contained the fine Fecralloy fibers after 225 hours of operation in the $840^{\circ} \mathrm{C}\left(1550^{\circ} \mathrm{F}\right)$, sulfur and alkali-containing, simulated PFBC process gas environment. 

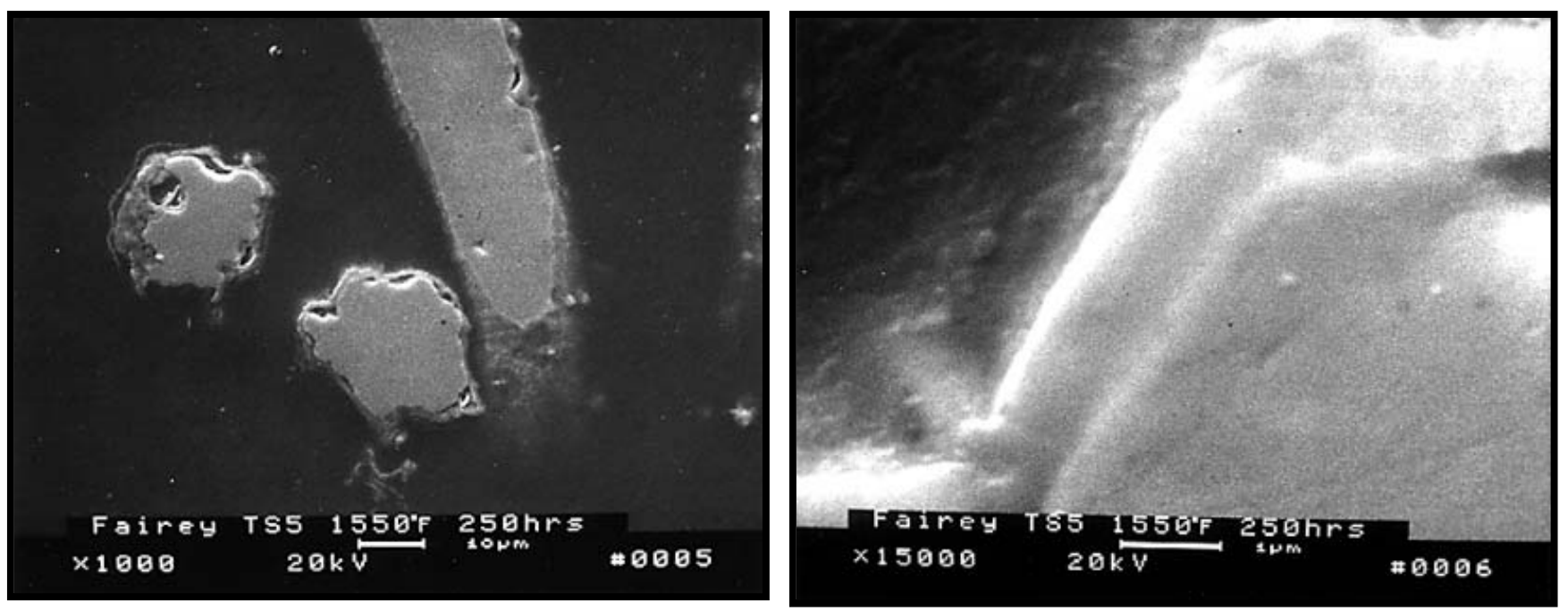

Figure 74 - Morphology of the coarse Fecralloy fibers contained within the Fairey Microfiltrex filtration media after 225 hours of operation in the $840^{\circ} \mathrm{C}\left(1550^{\circ} \mathrm{F}\right)$ simulated PFBC process gas environment that contained gas phase sulfur and alkali.

\subsection{Technetics Fecralloy}

\subsubsection{Simulated PFBC Operation}

The cross-sectioned surface of the $\sim 1.9 \mathrm{~mm}$, as-manufactured, Technetics Feltmetal Fecralloy, porous filter matrix is shown in Figure 75. The as-manufactured Technetics filter matrix was seen to consist of irregularly shaped (i.e., shaved) metal media fibers that were sinter bonded together, and which were structurally supported by either an external coarse or fine Fecralloy mesh screen, as well as internally embedded mesh screen layers. From the micrographs presented in Figure 75, a denser layer of fibers appeared to be present along the i.d. wall of the filtration mat layer in comparison to areas where fibers were embedded within the structural support mesh screens along the o.d. surface of the filter element. The structural integrity of the Technetics Feltmetal filtration media resulted from the inclusion of the multi-layered mesh screens. This is in contrast to the U.S.Filter-Fluid Dynamics (USF) filter media which incorporated a thick-walled perforated metal cylindrical insert along the i.d. surface of the filter element to provide enhanced structural support and strength, or the Fairey Microfiltrex filter media which utilized an outer mesh, as well as an interior, thick-walled, perforated metal architecture.

The open porosity of the Technetics Feltmetal Fecralloy filter matrix was retained after 500 hours of exposure to the $650^{\circ} \mathrm{C}\left(1200^{\circ} \mathrm{F}\right)$ simulated PFBC process gas environment. The composition of the Technetics Fecralloy filtration mat fibers appeared to be comparable to that of the exterior and interior-embedded, structural support mesh screen, thus making the Feltmetal filter matrix a compositionally homogeneous filter body.

The formation of a detectable oxide-enriched layer along the o.d. surface of the filtration mat fibers or structural support mesh screens was not observed during the initial 242 hours of exposure of the Technetics Feltmetal Fecralloy filter to the $650^{\circ} \mathrm{C}\left(1200^{\circ} \mathrm{F}\right)$ simulated PFBC process gas environment. With continued exposure, enrichment of aluminum was detected along the o.d. surface of the filtration mat fibers, as well as the structural support mesh. 

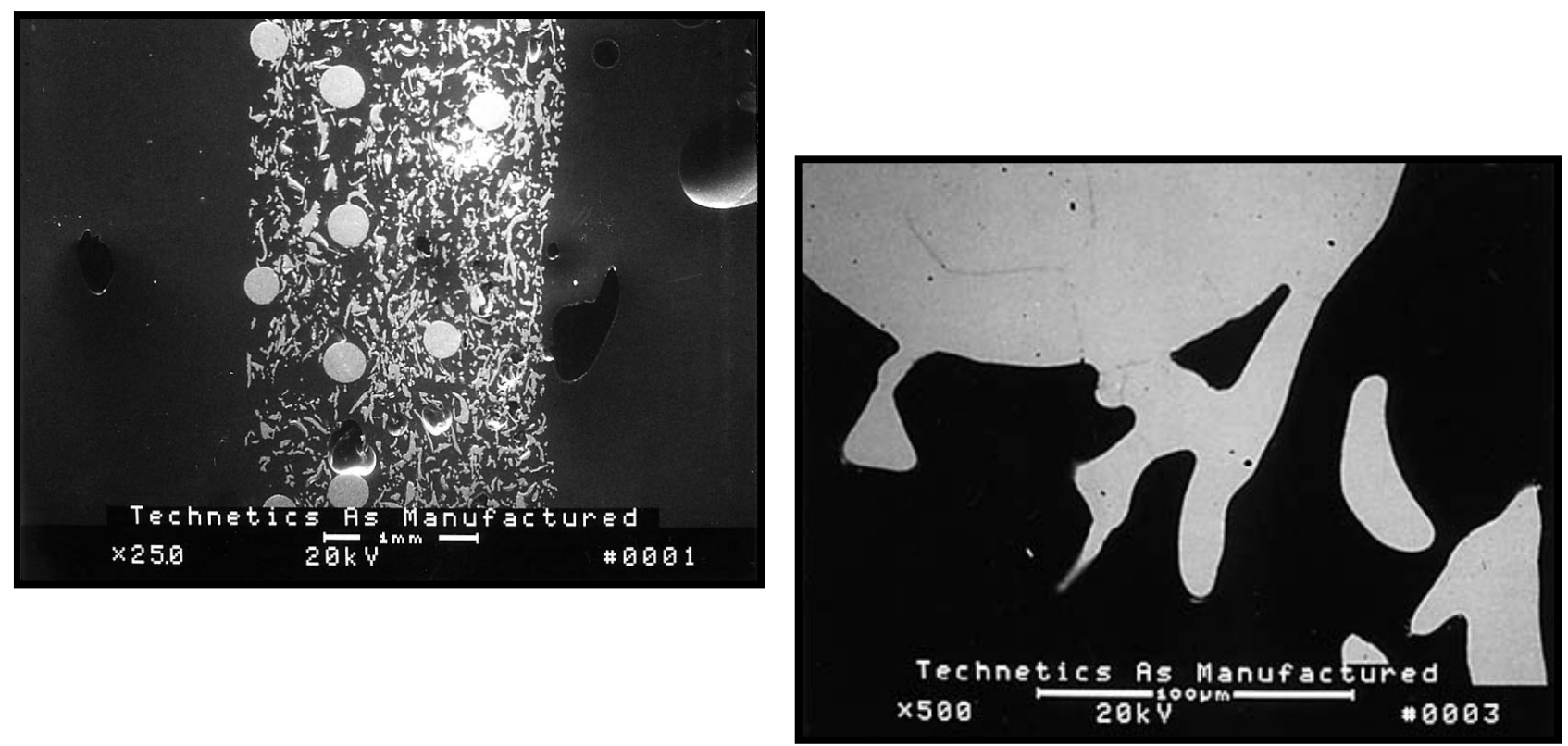

Figure 75 - Morphology of the as-manufactured Technetics Fecralloy filter media.

The open porosity of the $\sim 1.6 \mathrm{~mm}$ thick, sinter bonded, fibrous, Technetics filtration media was retained after 1016 hours of exposure in the $760^{\circ} \mathrm{C}\left(1400^{\circ} \mathrm{F}\right)$ simulated PFBC process gas environment. Limited oxidation resulted along the surface of the shaved, sinter bonded, Fecralloy fibers. As a function of time, the thickness of the external oxide layer increased from $0.13 \mu \mathrm{m}$ after 258 hours of operation to $0.5-0.8 \mu \mathrm{m}$ after 1016 hours of operation (Figure 76). With time, the composition of the oxide changed from initially being enriched with an iron oxide complex, to that of an iron-alumina-oxygen-enriched phase (i.e., iron aluminate).

Limited oxidation resulted along the outer surface of the embedded Technetics Fecralloy structural support mesh. The thickness of the oxide layer ranged from 0.2 to $0.6 \mu \mathrm{m}$.

Compositionally, the oxide layer was determined to be enriched with oxygen, iron, and aluminum (i.e., iron aluminate).

Similarly the open porosity of the porous, sinter bonded, Technetics Fecralloy filtration media was retained after 986 hours of operation in the $815-840^{\circ} \mathrm{C}\left(1500-1550^{\circ} \mathrm{F}\right)$ simulated $\mathrm{PFBC}$ process gas environment. The thickness of the oxide layer that formed along the outer surface of the Fecralloy fibers and embedded mesh increased with extended exposure time $(\sim 0.5-1.0 \mu \mathrm{m}$, and $\sim 0.66-2.2 \mu \mathrm{m}$, respectively; Figure 77). The composition of the oxide layer that formed along the outer surface of the Fecralloy fibers consisted of alumina or alumina/iron oxide (iron aluminate) phases, while the oxide layer that formed along the outer surface of the embedded mesh consisted principally of alumina with minor contributions of iron oxide.

The open porosity of the porous, sinter bonded, Technetics Fecralloy filtration media was similarly retained after 546.5 hours of operation in the $840^{\circ} \mathrm{C}\left(1550^{\circ} \mathrm{F}\right)$, gas phase sulfur-free, simulated PFBC process gas environment. 


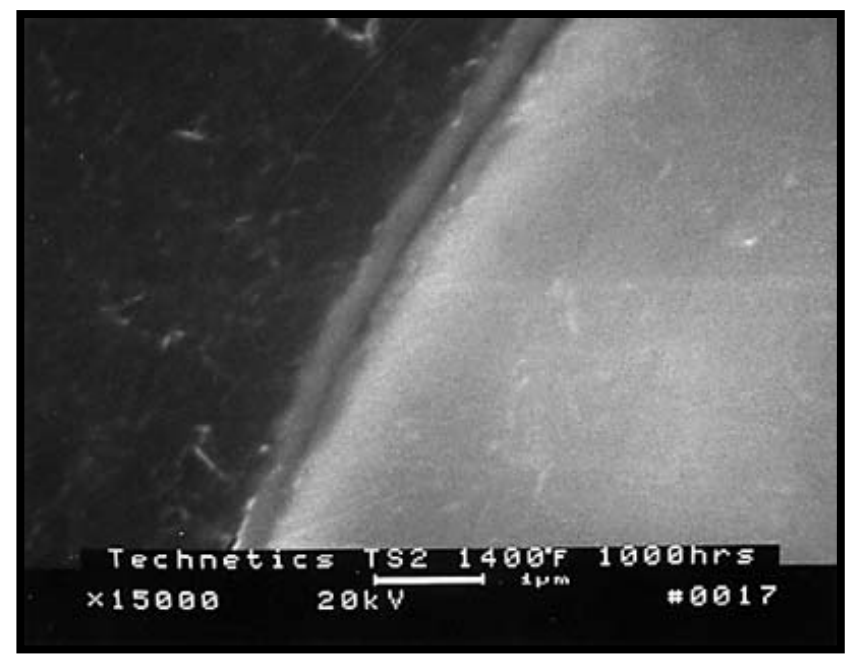

Figure 76 - High magnification micrograph illustrating the thickness and morphology of the oxide layer that formed along the outer surface of the cross-sectioned Fecralloy fibers contained within the 1016 hour, $760^{\circ} \mathrm{C}\left(1400^{\circ} \mathrm{F}\right)$, simulated PFBC-exposed, Technetics filtration media.
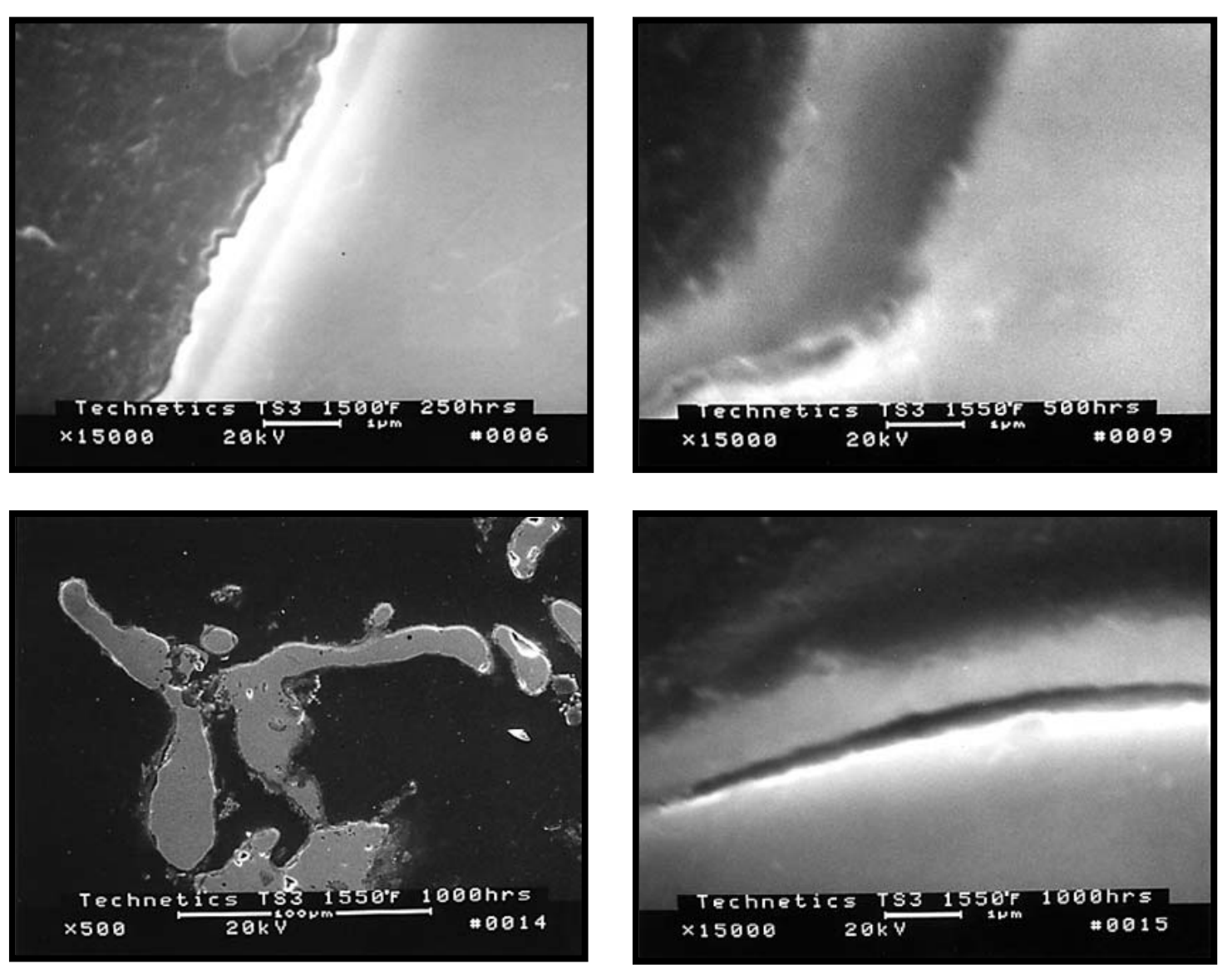

Figure 77 - Microstructure of the Technetics Fecralloy filtration media as a result of operation in the $815-840^{\circ} \mathrm{C}\left(1500-1550^{\circ} \mathrm{F}\right)$ simulated $\mathrm{PFBC}$ process gas environment. 
The thickness of the oxide layer that formed along the outer surface of the Technetics Fecralloy fibers and embedded mesh generally remained relatively constant with extended exposure ( $\sim 0.2-0.4 \mu \mathrm{m}$, and $\sim 0.13 \mu \mathrm{m}$, respectively). In the gas phase sulfur-free environment, the thickness of the oxide layer that resulted along the surface of the Fecralloy fibers and embedded mesh was less than that which resulted during exposure of the Technetics filtration media to the sulfurcontaining, simulated PFBC process gas environment.

The composition of the oxide layer that formed along the outer surface of the Fecralloy fibers consisted initially of an iron/aluminum oxide phase (i.e., iron aluminate). With time, the oxide tended to be enriched with alumina. The composition of the oxide layer that formed along the outer surface of the embedded mesh consisted initially of an iron oxide complex. With time, the composition of the oxide layer consisted of an iron/aluminum oxide phase (i.e., iron aluminate).

\subsubsection{Impact of Gas Phase Alkali}

Extensive surface and internal oxidation of the Fecralloy fibers, and surface oxidation of the embedded mesh, resulted along the outer surface, and approximately through one-half of the cross-sectioned Technetics filtration media as a result of operation in the $840^{\circ} \mathrm{C}\left(1550^{\circ} \mathrm{F}\right)$ simulated PFBC process gas environment that contained gas phase sulfur and alkali (Figure 78). Oxidation of the Fecralloy fibers limited the open porosity of the filter matrix, restricting flow of the process gas through the filter wall.

Where extensive oxidation resulted within the Technetics filter media, an iron oxide phase primarily formed along the outer surface of the Fecralloy fibers (Figure 79). Internal oxidation of the base metal principally lead to the formation of a chromia/iron oxide-enriched matrix. In contrast limited oxidation of the Fecralloy fibers resulted along the inner or pulse cycled surface of the Technetics filter media (Figure 80).

An aluminum/iron oxide-enriched phase initially formed along the outer surface of the extensively oxidized embedded mesh. With time, the composition of the surface oxide contained either alumina or chromia (Figure 81).

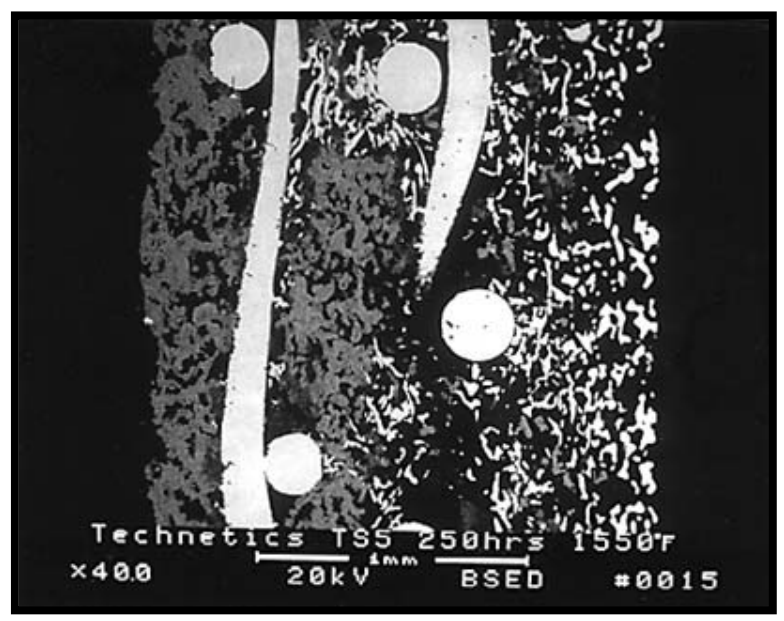

Figure 78 - Morphology of the Technetics Fecralloy filtration media after 225 hours of operation in the $840^{\circ} \mathrm{C}\left(1550^{\circ} \mathrm{F}\right)$ simulated $\mathrm{PFBC}$ process gas environment containing gas phase sulfur and alkali. 


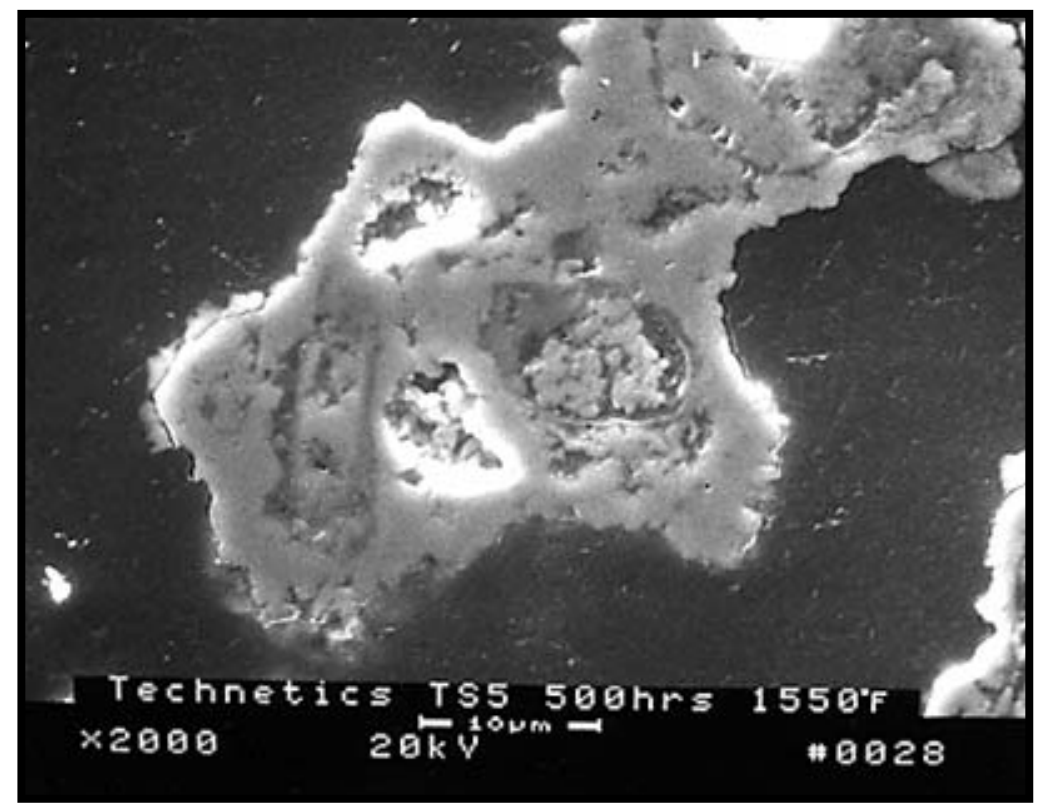

Figure 79 - Higher magnification micrograph illustrating the extensive surface and internal oxidation of the Fecralloy fibers that were present along the outer surface of the Technetics filtration media after 496 hours of operation in the $840^{\circ} \mathrm{C}\left(1550^{\circ} \mathrm{F}\right)$ simulated PFBC process gas environment that contained gas phase sulfur and alkali.

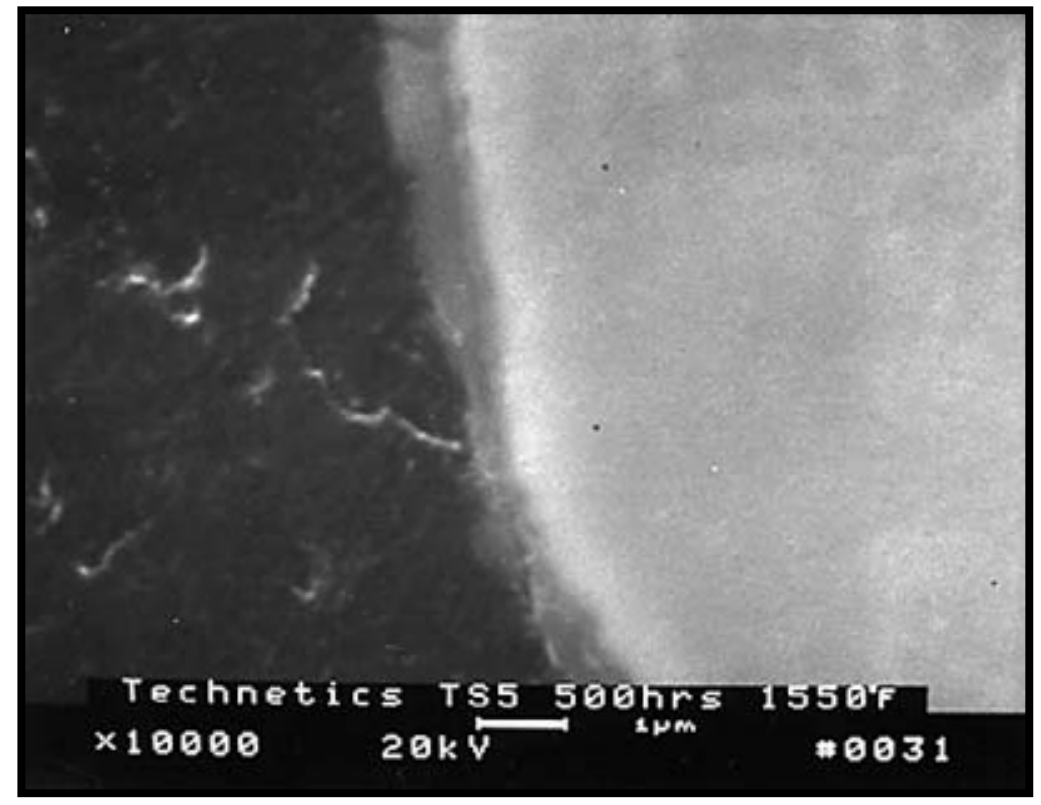

Figure 80 - Micrographs illustrating the morphology and thickness of the oxide formation that resulted along the outer surface of the Technetics Fecralloy fibers that were located near the i.d. or pulse cycled surface of the 496 hour, $840^{\circ} \mathrm{C}\left(1550^{\circ} \mathrm{F}\right)$, simulated PFBC-exposed, filter media. 

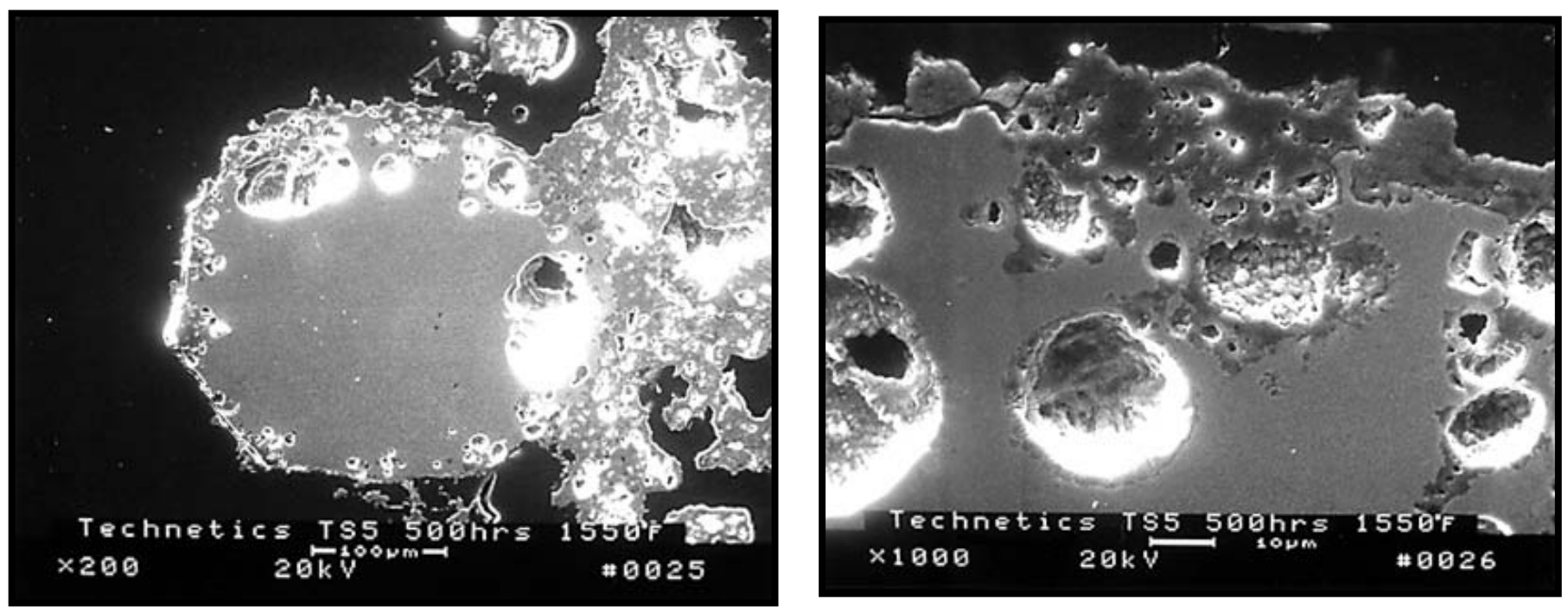

Figure 81 - Higher magnification micrographs illustrating extensive oxidation of the Fecralloy fibers and embedded mesh that were present along the outer surface of the Technetics filtration media after 496 hours of operation in the $840^{\circ} \mathrm{C}\left(1550^{\circ} \mathrm{F}\right)$, gas phase sulfur and alkali-containing, simulated $\mathrm{PFBC}$ process gas environment. 
During conduct of the final test campaign (Test Campaign No. 6), metal filter elements were subjected to

- 81 hours of $840^{\circ} \mathrm{C}\left(1550^{\circ} \mathrm{F}\right)$, steady state, particulate filtration

- 10,111 accelerated pulse cleaning cycles, representing 5055 hours of operating life

- 17 thermal transients

in order to demonstrate not only particulate filtration collection capability, but also the stability of each metal matrix architecture to withstand extended life under accelerated pulse cycling and extreme thermal transient conditions. In Test Campaign No. 6, Siemens Westinghouse Power Corporation (SWPC) introduced an additional sinter bonded, fibrous, Fecralloy filter element manufactured by Bekaert/Mott into the test program. The Bekaert/Mott filter element consisted of a Fecralloy felt mat that was wrapped over a cylindrical, open mesh metal grid, structural support. The felt mat was joined by a longitudinal seam weld to form the outer surface of the filter body. Joiner end rings and a closed end cap were welded onto the cylindrical filter element section. As with all metal filter elements, SWPC's fail-safe/regenerator was welded to the filter body, forming the flange.

As shown in Figure 82 and Table 6, $1.5 \mathrm{~m}$ and $2.0 \mathrm{~m}$ Bekaert/Mott Fecralloy and Pall FeAl filter elements, and $1.5 \mathrm{~m}$ Microfiltrex Fecralloy and U.S Filter/Fluid Dynamics (USF) $316 \mathrm{~L}^{10}$ filter elements were included in the Test Campaign No. 6 filter array. Ceramic candle filters were additionally installed within the filter array, ${ }^{11}$ thus subjecting both filter element types to similar simulated PFBC operating conditions.

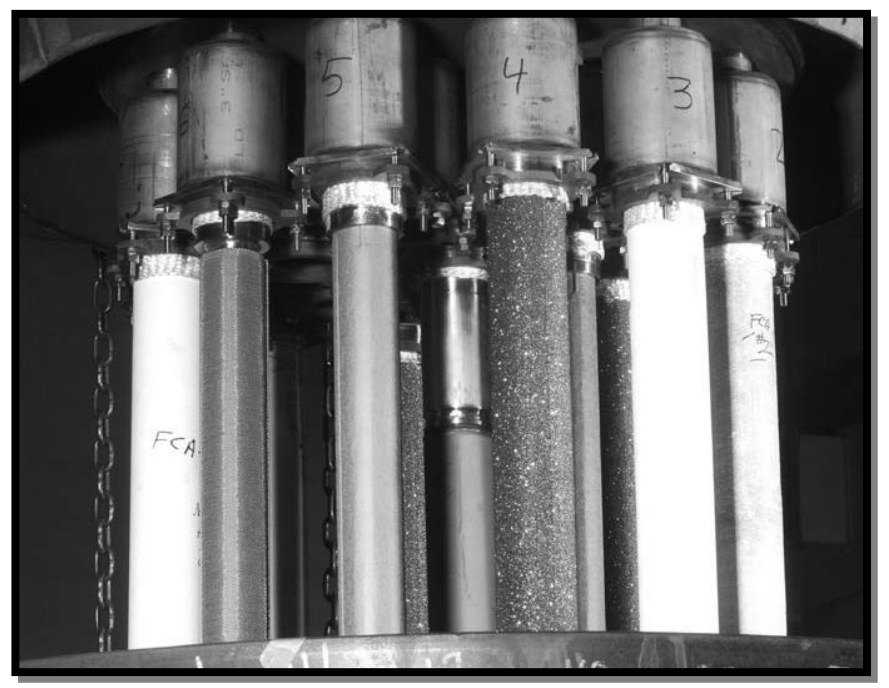

Figure 82 - Filter element array for demonstration of particulate removal capabilities and thermal stability of $1.5 \mathrm{~m}$ and $2.0 \mathrm{~m}$ candle filter elements.

\footnotetext{
${ }^{10}$ USF commercial grade filter media architecture. SWPC does not support 316L for extended use in high temperature PFBC filter applications due to its lack of oxidative stability.

${ }^{11}$ Testing conducted under SWPC STC's Filter Component Assessment program (DOE/NETL Contract No. DE-AC21-94MC31147).
} 


\begin{tabular}{|c|c|c|c|c|c|}
\hline \multicolumn{6}{|c|}{$\begin{array}{c}\text { TABLE } 6 \\
\text { CANDLE FILTER ARRAY — STEADY STATE, ACCELERATED PULSE CYCLING AND }\end{array}$} \\
\hline $\begin{array}{c}\text { Array } \\
\text { Position }\end{array}$ & Filter Element & $\begin{array}{l}\text { Length, } \\
\text { m }\end{array}$ & $\begin{array}{l}\text { Steady State } \\
\text { Testing }\end{array}$ & $\begin{array}{c}\text { Accelerated Pulse Cycle } \\
\text { Testing }\end{array}$ & $\begin{array}{c}\text { Thermal Transient } \\
\text { Testing }\end{array}$ \\
\hline 1 & $\begin{array}{c}\text { DuPont PRD-66 } \\
\text { C736 } \\
\end{array}$ & 1.5 & $\begin{array}{l}\text { Intact; Planned Removed } \\
\text { after Steady State Testing }\end{array}$ & - & - \\
\hline 2 & $\begin{array}{l}\text { Techniweave CFCC } \\
\text { IP3488-AITF2-03 }\end{array}$ & 1.5 & $\begin{array}{l}\text { Intact; Planned Removed } \\
\text { after Steady State Testing }\end{array}$ & - & - \\
\hline 3 & $\begin{array}{c}\text { Blasch } \\
\text { \#3 }\end{array}$ & 1.5 & $\begin{array}{l}\text { Intact; Planned Removed } \\
\text { after Steady State Testing }\end{array}$ & - & - \\
\hline 4 & $\begin{array}{l}\text { Ferro } \mathrm{SiC} \\
\quad \# 2 \\
\end{array}$ & 1.5 & $\begin{array}{l}\text { Intact; Planned Removed } \\
\text { after Steady State Testing }\end{array}$ & - & - \\
\hline 5 & $\begin{array}{c}\text { Bekaert/Mott } \\
\text { Fecralloy } \\
\text { SW030122006 }\end{array}$ & 1.5 & $\begin{array}{l}\text { Intact; Retained for } \\
\text { Continued Testing }\end{array}$ & $\begin{array}{c}\text { Wrinkling of the Filtration } \\
\text { Media; Gap Formed along the } \\
\text { Longitudinal Seam Observed } \\
\text { after Completion of } \\
\text { Accelerated Pulse Cycle } \\
\text { Testing; Element Retained } \\
\text { within the Array for Thermal } \\
\text { Transient Testing }\end{array}$ & $\begin{array}{c}\text { Intact; Canted/Bowed; } \\
\text { Wrinkling of the Filtration Media; } \\
\text { Gap along the Longitudinal Seam } \\
\text { Observed; } \\
\text { Cross-Sectioned for } \\
\text { Microstructural Analysis }\end{array}$ \\
\hline 6 & $\begin{array}{l}\text { Microfiltrex } \\
\text { Fecralloy } \\
\text { ICC108618 }\end{array}$ & 1.5 & $\begin{array}{l}\text { Intact; Retained for } \\
\text { Continued Testing }\end{array}$ & $\begin{array}{l}\text { Wrinkling of the Filtration } \\
\text { Media at the Metal Joiner } \\
\text { Ring Observed after } \\
\text { Completion of Accelerated } \\
\text { Pulse Cycle Testing; Retained } \\
\text { within the Array for Thermal } \\
\text { Transient Testing }\end{array}$ & $\begin{array}{l}\text { Intact; Canted/Bowed; } \\
\text { Wrinkling of the Filtration Media } \\
\text { at the Metal Joiner Ring; } \\
\text { Cross-Sectioned for } \\
\text { Microstructural Analysis }\end{array}$ \\
\hline 7 & $\begin{array}{c}\text { DuPont PRD-66 } \\
\text { C-638 }\end{array}$ & 1.5 & $\begin{array}{l}\text { Intact; Retained for } \\
\text { Continued Testing }\end{array}$ & $\begin{array}{c}\text { Intact; Retained for Thermal } \\
\text { Transient Testing }\end{array}$ & Intact \\
\hline 8 & $\begin{array}{l}\text { Techniweave CFCC } \\
\text { IP3488 AITF } \mathbf{1 - 0 3}\end{array}$ & 1.5 & $\begin{array}{l}\text { Intact; Retained for } \\
\text { Continued Testing }\end{array}$ & $\begin{array}{c}\text { Intact; Retained for Thermal } \\
\text { Transient Testing } \\
\end{array}$ & Intact \\
\hline 9 & $\begin{array}{c}\text { Blasch } \\
\# 9 \\
\end{array}$ & 1.5 & $\begin{array}{l}\text { Intact; Retained for } \\
\text { Continued Testing }\end{array}$ & $\begin{array}{c}\text { Intact; Retained for Thermal } \\
\text { Transient Testing }\end{array}$ & $\begin{array}{l}\text { Broken on Removal from the Filter } \\
\text { Array }\end{array}$ \\
\hline 10 & $\begin{array}{l}\text { Ferro } \mathrm{SiC} \\
\quad \# \mathbf{1}\end{array}$ & 1.5 & $\begin{array}{l}\text { Intact; Retained for } \\
\text { Continued Testing }\end{array}$ & $\begin{array}{c}\text { Intact; Retained for Thermal } \\
\text { Transient Testing }\end{array}$ & Intact \\
\hline 11 & $\begin{array}{l}\text { Pall FeAl } \\
\quad \# 11\end{array}$ & 1.5 & $\begin{array}{l}\text { Intact; Retained for } \\
\text { Continued Testing }\end{array}$ & $\begin{array}{c}\text { Intact; Retained for Thermal } \\
\text { Transient Testing }\end{array}$ & $\begin{array}{l}\text { Intact; Cross-Sectioned for } \\
\text { Microstructural Analysis }\end{array}$ \\
\hline 12 & $\begin{array}{l}\text { USF 316L* } \\
\text { D215 \#6 }\end{array}$ & 1.5 & $\begin{array}{l}\text { Intact; Retained for } \\
\text { Continued Testing }\end{array}$ & $\begin{array}{c}\text { Intact; Retained for Thermal } \\
\text { Transient Testing }\end{array}$ & $\begin{array}{l}\text { Intact; Cross-Sectioned for } \\
\text { Microstructural Analysis }\end{array}$ \\
\hline 13 & $\begin{array}{c}\text { Ferro SiC } \\
\# 2\end{array}$ & 2.0 & $\begin{array}{l}\text { Intact; Retained for } \\
\text { Continued Testing }\end{array}$ & $\begin{array}{c}\text { Intact; Retained for Thermal } \\
\text { Transient Testing }\end{array}$ & Intact \\
\hline 14 & $\begin{array}{c}\text { Bekaert/Mott } \\
\text { Fecralloy } \\
\text { SW03 } 122001\end{array}$ & 2.0 & $\begin{array}{l}\text { Element Removed after } \\
\text { Steady State Testing; Hole } \\
\text { through the Filtration } \\
\text { Media; Wrinkling of the } \\
\text { Filtration Media; } \\
\text { Gaps/Openings along the } \\
\text { Longitudinal Seam Weld }\end{array}$ & - & - \\
\hline 15 & - & - & - & - & - \\
\hline 16 & - & - & - & - & - \\
\hline 17 & - & - & - & - & - \\
\hline 18 & $\begin{array}{c}\text { DuPont PRD-66 } \\
\text { C-738 } \\
\end{array}$ & 1.5 & $\begin{array}{l}\text { Intact; Retained for } \\
\text { Continued Testing }\end{array}$ & $\begin{array}{c}\text { Intact; Retained for Thermal } \\
\text { Transient Testing }\end{array}$ & Intact \\
\hline 19 & $\begin{array}{l}\text { Pall FeAl } \\
\quad \# 16\end{array}$ & 2.0 & $\begin{array}{l}\text { Intact; Retained for } \\
\text { Continued Testing }\end{array}$ & $\begin{array}{l}\text { Intact; Retained for Thermal } \\
\text { Transient Testing }\end{array}$ & Intact \\
\hline
\end{tabular}

* Commercial Grade Media.

(a) Steady State Testing: $81 \mathrm{hr} 6 \mathrm{~min}$; 14 pulse cleaning cycles delivered to the filter array.

Accelerated Pulse Cycle Testing: $419 \mathrm{hr} 46 \mathrm{~min}$; 10,110 pulse cleaning cycles delivered to the filter array.

Thermal Transient Testing: $87 \mathrm{hr} 45 \mathrm{~min} ; 17$ thermal transients conducted. 
After 81 hours of steady state testing, the filtration media along the outer surface of the $2.0 \mathrm{~m}$ Bekaert/Mott filter element was seen to have "wrinkled" or buckled (Figure 83). A hole was also seen to have formed through the filter media wall. The $2.0 \mathrm{~m}$ Bekaert/Mott element was removed from the filter array prior to continued testing.
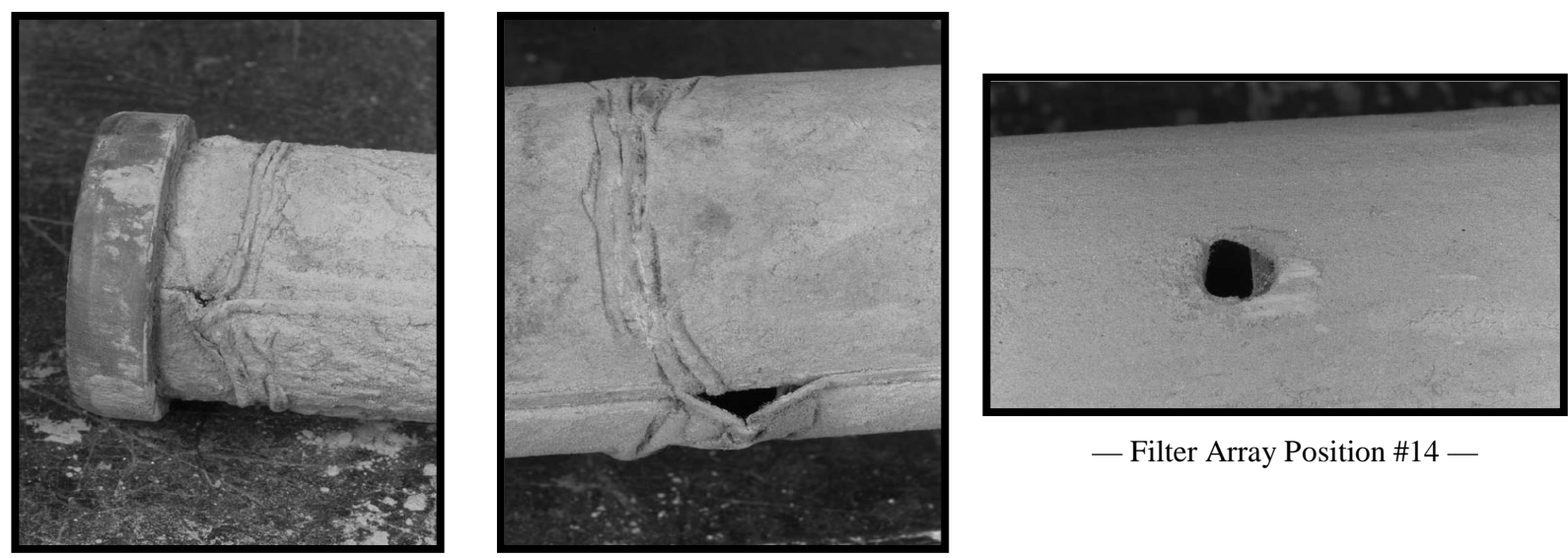

— Filter Array Position \#14 —

Figure 83 - Failure of the $2.0 \mathrm{~m}$ Bekaert/Mott candle filter after 81 hrs of high temperature, steady state, PFBC testing.

Wrinkling of the $1.5 \mathrm{~m}$ Bekaert/Mott and $1.5 \mathrm{~m}$ Microfiltrex filter media (Figure 84), and hole formations through the Bekaert/Mott filter body and along the longitudinal seam weld were also identified after completion of the accelerated pulse cycle segment of Test Campaign No. 6. In

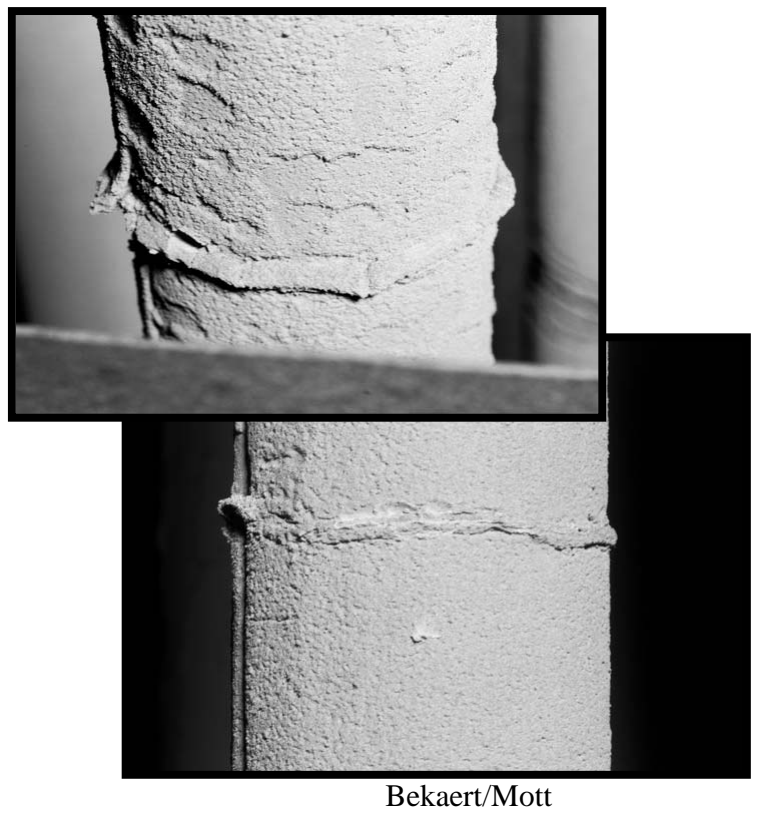

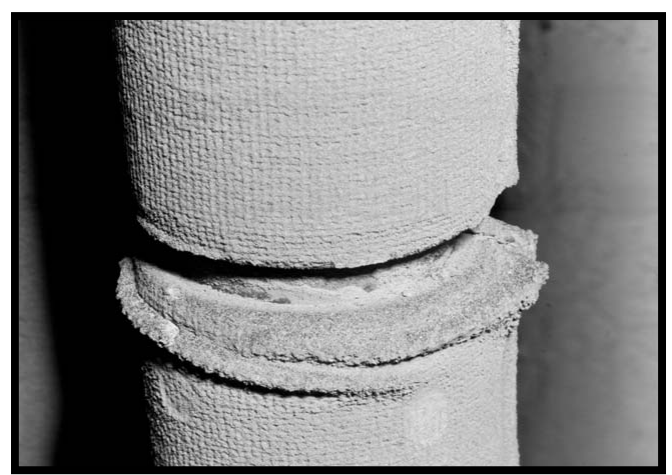

Microfiltrex

— Filter Array Position \#6 -

Figure 84 - Wrinkled appearance of the Bekaert/Mott and Microfiltrex filtration media after completion of the simulated PFBC accelerated pulse cycle test campaign. 
contrast, the Pall FeAl and USF 316L filter elements were visually observed to have remained intact during steady state and accelerated pulse cycle testing.

In a parallel effort at SWPC STC, a $1.5 \mathrm{~m}$ Bekaert/Mott element was exposed to the $840^{\circ} \mathrm{C}$ $\left(1550^{\circ} \mathrm{F}\right)$ simulated $\mathrm{PFBC}$ process gas environment containing gas phase sulfur and alkali (Table 7). Once again, "wrinkling' of the Bekaert/Mott filtration media resulted along the area adjacent to the metal joiner ring.

\begin{tabular}{|c|c|}
\hline \multicolumn{2}{|c|}{$\begin{array}{l}\text { TABLE } 7 \\
\text { CANDLE FILTER ARRAY }- \text { HIGH TEMPERATURE CORROSION } \\
\text { TESTING }\end{array}$} \\
\hline Position & Test Segment No. 1 (281 Hrs) \\
\hline 1 & McDermott SCS — \#1262 SCS \\
\hline 2 & DuPont PRD-66 - C741 New \\
\hline 3 & Techniweave CFCC — IP3488 AITF 4-03 \\
\hline 4 & Blasch -\#4 \\
\hline 5 & Ferro $\mathrm{SiC}-\# 3$ \\
\hline 6 & Bekaert/Mott Fecralloy - SW03 122005 \\
\hline
\end{tabular}

Since subsequent testing of the filter array identified in Table 6 included exposure to a series of seventeen thermal transients representing rapid system temperature decreases experienced during plant shutdown resulting from turbine trip events (Figure 85), the failed Bekaert/Mott and Microfiltrex elements were not removed from the filter array. After conducting the simulated thermal transient sequence, the filter array was slow cooled, and the vessel was open for inspection of the filter elements. The Bekaert/Mott and Microfiltrex elements were seen to be canted primarily below the welded mid-body metal joiner rings (Figure 86). In contrast, the $1.5 \mathrm{~m}$ and 2.0 $\mathrm{m}$ Pall FeAl and $1.5 \mathrm{~m}$ USF 316L filter elements were intact, without any apparent distortion to the metal architecture.

Since a particulate loading of $\sim 100-500 \mathrm{ppm}$ was measured in the isokinetic outlet gas samples taken during thermal transient testing, the $1.5 \mathrm{~m}$ Pall FeAl, USF 316L, Microfiltrex Fecralloy, and Bekaert/Mott Fecralloy filter elements were cross-sectioned in order to determine whether ash penetrated through the various porous metal, and to demonstrate the overall effective particulate removal capability of each metal filter media. As shown in Figure 87, ash fines were present along the i.d or pulse cycled surface of the Bekaert/Mott Fecralloy filter element. This primarily resulted from the wrinkled and gap formations that were observed along the longitudinal seam weld which permitted fines to pass directly from the dirty to the clean gas side of the filter array. A trace of ash was observed along the i.d. or pulse cycled surface of the Microfiltrex filter element, while visible evidence of ash was not observed along the i.d. surface of the Pall FeAl or USF 316L filter elements.

Scanning electron micrographs presented in Figure 88, indicate that although extensive oxidation of the commercial USF $316 \mathrm{~L}$ filter media resulted under $840^{\circ} \mathrm{C}\left(1550^{\circ} \mathrm{F}\right)$ simulated PFBC operating conditions, both the USF $316 \mathrm{~L}$ and Pall FeAl filter media prevented fines penetration through the porous sinter bonded metal media architecture. In contrast, ash fines were limitedly detected along the o.d. and i.d. surfaces of the Microfiltrex and Bekaert/Mott Fecralloy 

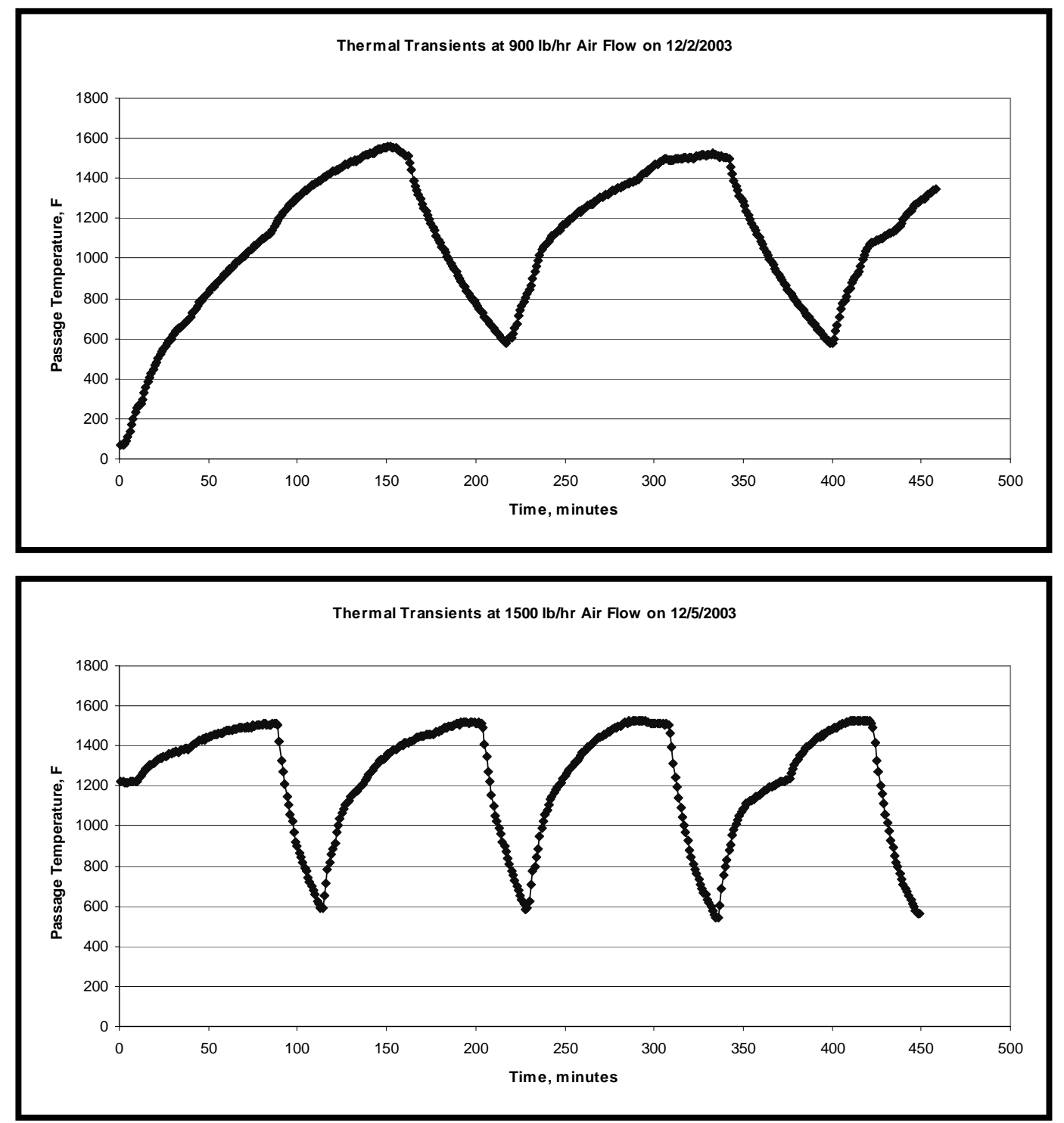

\begin{tabular}{|c|c|c|c|c|c|c|}
\hline \multirow{2}{*}{$\begin{array}{l}\text { Number of } \\
\text { Transients } \\
\text { Conducted }\end{array}$} & \multicolumn{3}{|c|}{$\begin{array}{l}\text { Temperature Decrease } \\
\text { during Transient Event }\end{array}$} & \multicolumn{3}{|c|}{$\begin{array}{l}\text { Temperature Increase } \\
\text { during System Reheat }\end{array}$} \\
\hline & 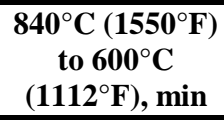 & $\begin{array}{c}\Delta \mathbf{T}\left({ }^{\circ} \mathbf{F}\right) / \\
\text { Initial } 1 \text { min }\end{array}$ & $\begin{array}{c}\Delta \mathbf{T}\left({ }^{\circ} \mathbf{F}\right) / \\
\text { Initial } 5 \text { min }\end{array}$ & $\begin{array}{c}600^{\circ} \mathrm{C}\left(1112{ }^{\circ} \mathrm{F}\right) \\
{\text { to } 840^{\circ} \mathrm{C}}^{\left(1550^{\circ} \mathrm{F}\right), \mathrm{min}}\end{array}$ & $\begin{array}{c}\Delta \mathbf{T}\left({ }^{\circ} \mathbf{F}\right) / \\
\text { Initial } 1 \text { min }\end{array}$ & $\begin{array}{c}\Delta \mathbf{T}\left({ }^{\circ} \mathbf{F}\right) / \\
\text { Initial } 5 \text { min }\end{array}$ \\
\hline $\begin{array}{c}2 \\
5 \\
10\end{array}$ & $\begin{array}{c}\sim 65 \\
\sim 35-40 \\
\sim 24\end{array}$ & $\begin{array}{l}-50 \\
-68 \\
-86\end{array}$ & $\begin{array}{l}-172 \\
-280 \\
-338\end{array}$ & $\begin{array}{l}\sim 130 \\
\sim 125 \\
\sim 88\end{array}$ & $\begin{array}{l}+45 \\
+49 \\
+82\end{array}$ & $\begin{array}{l}+180 \\
+164 \\
+259\end{array}$ \\
\hline
\end{tabular}

Figure 85 - Temperature profile during thermal transient testing. 
metal filter media. Although passage of fines through the Bekaert/Mott and Microfiltrex Fecralloy filter wall was not expected to have occurred during conduct of the steady state, accelerated pulse cycling, thermal transient test campaign, failure of the felt mat architecture and seam welds, and the extent of open porosity for capture and retention of ash fines require additional development prior to commercial use of these filter elements. In terms of chemical stability, limited oxidation was seen to have resulted along the sinter bonded particles contained within the Pall FeAl filter element, and within the sinter bonded fibrous Bekaert/Mott and Microfiltrex Fecralloy filter elements.

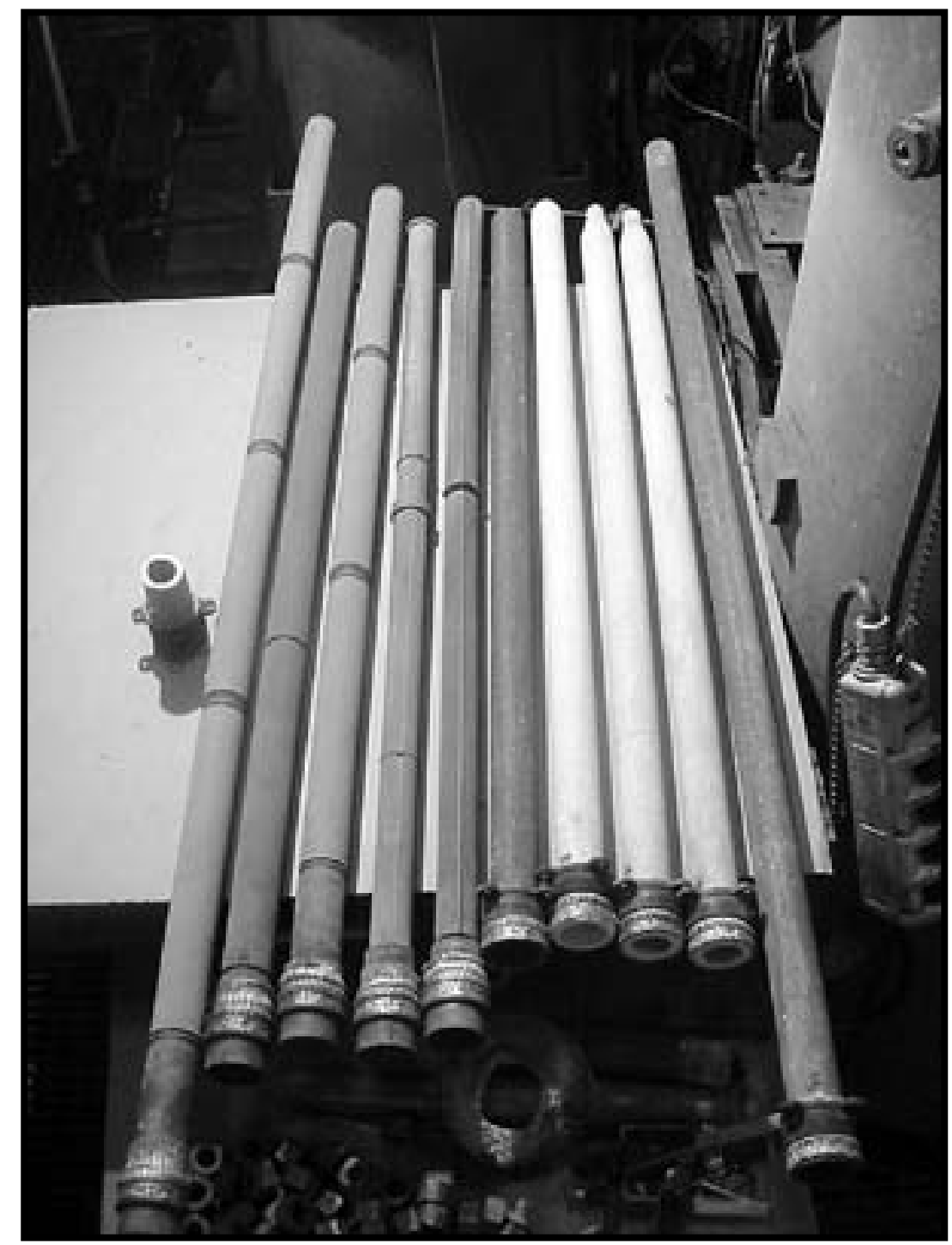

Figure 86 - Filter elements at the conclusion of steady state, accelerated pulse cycling, and thermal transient testing. From left to right: $2.0 \mathrm{~m}$ Pall FeAl, $1.5 \mathrm{~m}$ USF 316L, $1.5 \mathrm{~m}$ Pall FeAl, $1.5 \mathrm{~m}$ Bekaert/Mott Fecralloy, and 1.5 m Microfiltrex Fecralloy metal media filter elements; $1.5 \mathrm{~m}$ Ferro SiC, $1.5 \mathrm{~m}$ Techniweave CFCC, two $1.5 \mathrm{~m}$ DuPont PRD-66, and 2.0 m Ferro SiC ceramic filter elements. 


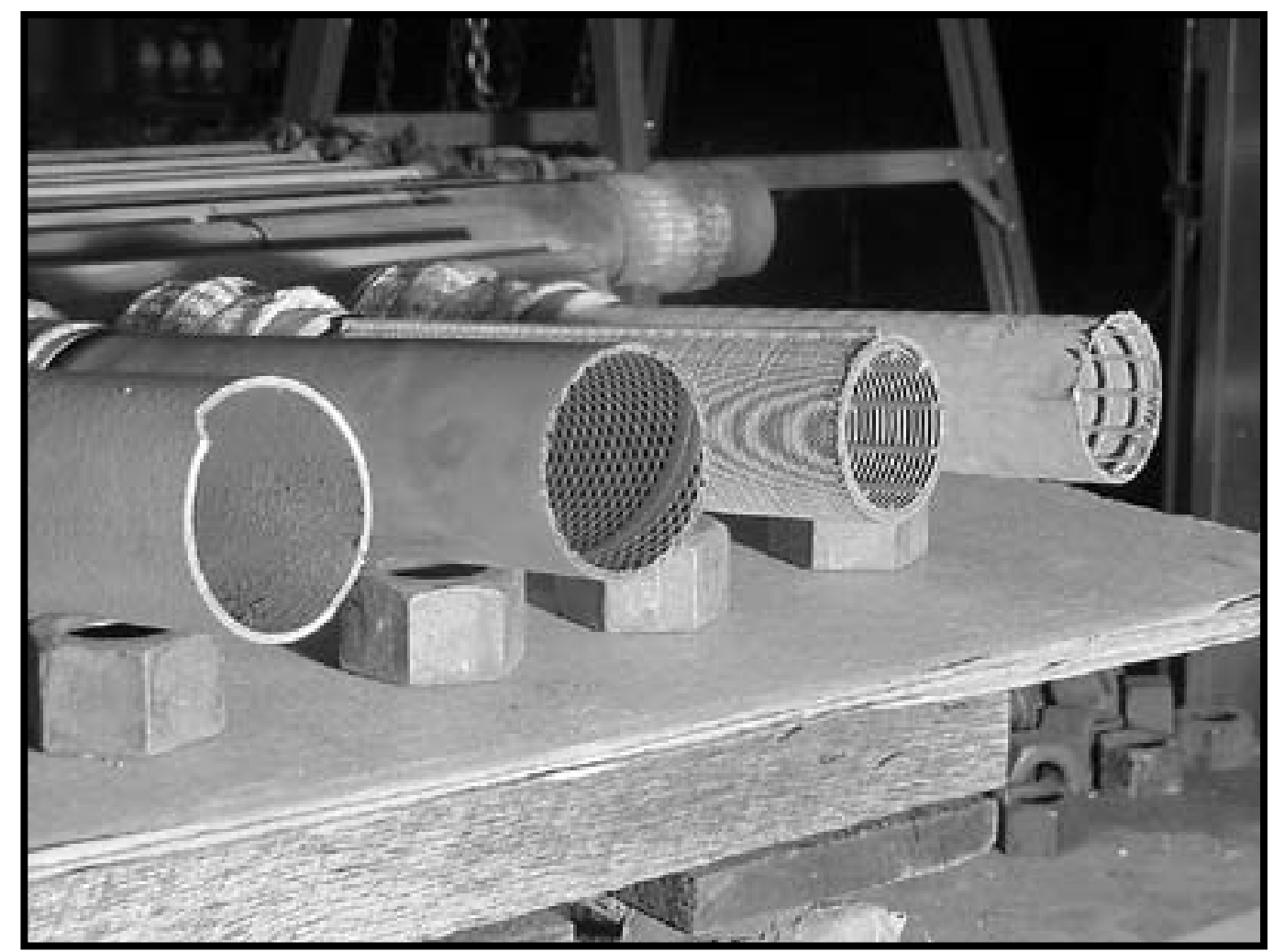

Figure 87 - Photograph illustrating the absence of ash fines along the i.d. or pulse cycled surface of the Pall FeAl, USF 316L, and Microfiltrex Fecralloy filter elements, but minor presence of ash along the i.d. or pulse cycled surface of the Bekaert/Mott Fecralloy filter element at the conclusion of the steady state, accelerated pulse cycle, and thermal transient test campaign. From left to right: Pall FeAl, USF 316L, Microfiltrex Fecralloy, and Bekaert/Mott Fecralloy. 

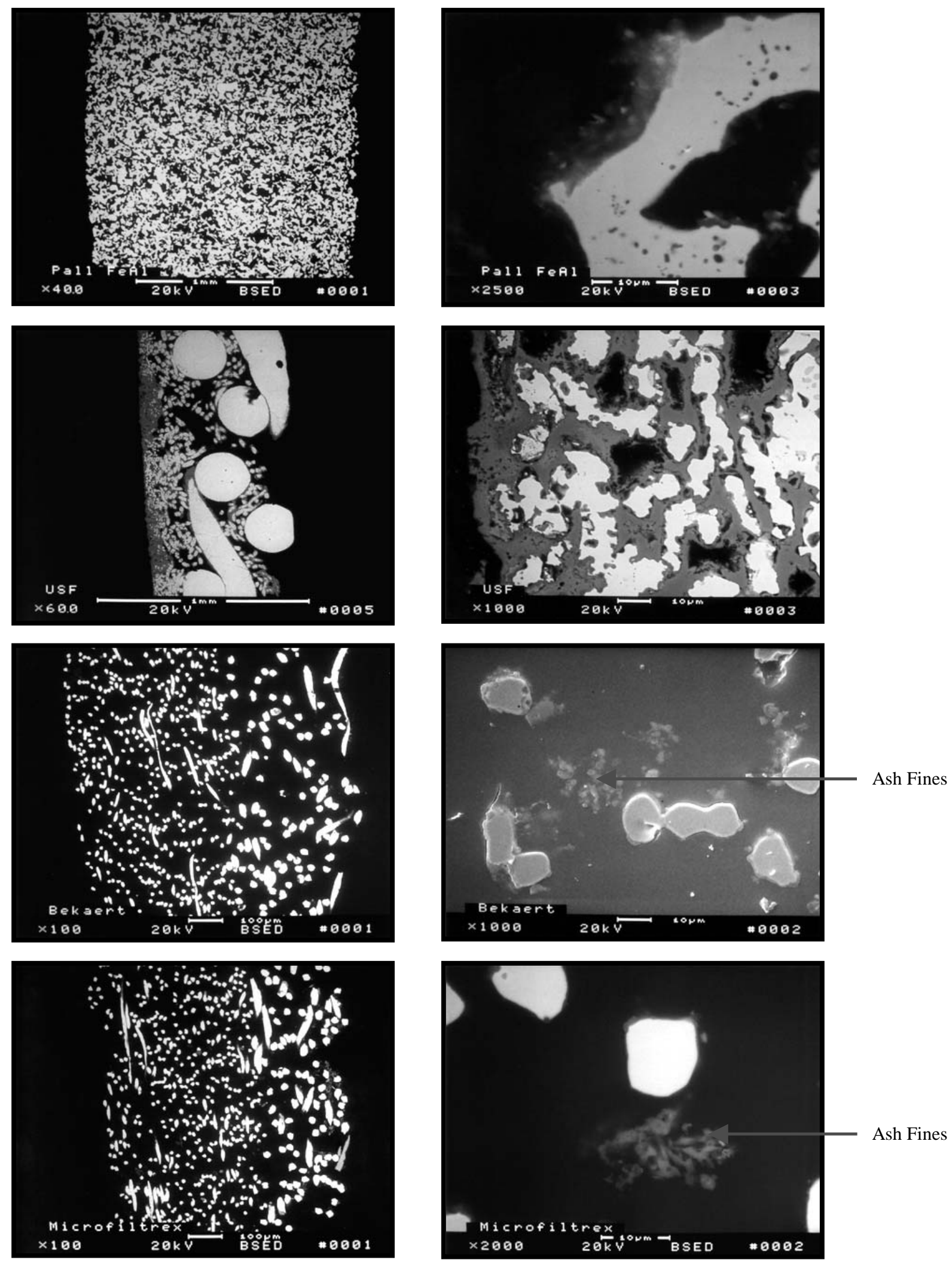

Figure 88 - Scanning electron micrographs illustrating limited penetration of ash fines into the Bekaert/Mott and Microfiltrex Fecralloy filtration media. 
In order to assess the potential viability of metal filter elements for use in pressurized fluidized-bed combustion (PFBC) or pressurized circulating fluidized-bed combustion (PCFBC) systems, the integrity of the filter component architecture, filtration media strength, as well as high temperature corrosion or accelerated oxidative stability, and retention of open porosity through the sinter bonded fibers or particles need to be addressed. Appendix A summarizes the details described in this report, identifying the stability, response, and recommendation for PFBC use of the ten intermetallic, advanced alloy and commercial metal media used to manufacture the U.S. Filter/Fluid Dynamics (USF), Pall, Mott, Fairey Microfiltrex, and Technetics filter elements. Table 8 provides an overview summary, identifying the recommended potential use of the various metal filter elements for extended operation in $1,013 \mathrm{kPa}(147 \mathrm{psia}), 650^{\circ} \mathrm{C}\left(1200^{\circ} \mathrm{F}\right), 760^{\circ} \mathrm{C}$ $\left(1400^{\circ} \mathrm{F}\right)$, and $840^{\circ} \mathrm{C}\left(1550^{\circ} \mathrm{F}\right), \mathrm{PFBC}$ systems containing $200 \mathrm{ppmv} \mathrm{SO}_{2} / \mathrm{SO}_{3}$, in the presence or absence of 1 ppm gas phase alkali.

\begin{tabular}{|c|c|c|c|c|c|}
\hline \multicolumn{6}{|c|}{$\begin{array}{c}\text { TABLE } 8 \\
\text { RECOMMENDED USE OF METAL FILTER ELEMENTS IN PFBC APPLICATIONS }\end{array}$} \\
\hline \multirow[b]{2}{*}{$\begin{array}{l}\text { Filter } \\
\text { Media }\end{array}$} & \multicolumn{5}{|c|}{ PFBC Process Operating Conditions } \\
\hline & $6^{650^{\circ}} \mathrm{C}\left(1200^{\circ} \mathrm{F}\right)$ & $7_{60}^{\circ} \mathrm{C}\left(1400^{\circ} \mathrm{F}\right)$ & $\begin{array}{c}815-840^{\circ} \mathrm{C} \\
(1500-1550\end{array}$ & $\begin{array}{c}840^{\circ} \mathrm{C}\left(1550^{\circ} \mathrm{F}\right) \\
-\mathrm{NoSO}_{2}-\end{array}$ & $\begin{array}{l}840^{\circ} \mathrm{C}\left(1550^{\circ} \mathrm{F}\right) \\
-\mathrm{SO}_{2} \& \mathrm{Na}-\end{array}$ \\
\hline Pall FeAl & Yes & Yes & Yes & Yes & $\overline{\text { No }}$ \\
\hline $\begin{array}{l}\text { Microfiltrex } \\
\text { Fecralloy }\end{array}$ & Yes & Yes & Yes & Yes & No \\
\hline $\begin{array}{l}\text { Technetics } \\
\text { Fecralloy }\end{array}$ & Yes & Yes & Yes & Yes & No \\
\hline USF Fecralloy & Yes & Yes & Yes & Yes & No \\
\hline USF Haynes 230 & Short-term* & Short-term & Short-term & Short-term & No \\
\hline USF Haynes 214 & Short-term & Short-term & Short-term & Short-term & No \\
\hline USF Haynes 188 & Short-term & Short-term & Short-term & No & No \\
\hline USF Haynes 566 & Short-term & No & No & No & No \\
\hline USF Hastelloy $X$ & Yes & Short-term & Short-term & No & No \\
\hline Pall Hastelloy X & Yes & Yes & Short-term & Short-term & No \\
\hline USF Inconel 600 & Short-term & Short-term & Short-term & Short-term & No \\
\hline Mott Inconel 600 & Yes & Yes & Short-term & Short-term & No \\
\hline USF 310S & Short-term & No & No & No & No \\
\hline Pall 310S & Short-term & Short-term & No & No & No \\
\hline
\end{tabular}

In the presence of 1 ppmv gas phase alkali, accelerated oxidation, pore closure, crack formations through the surface oxide formation, and/or removal of filter media sections limit the use of all porous sinter bonded metal media filter elements during operation in an $840^{\circ} \mathrm{C}\left(1550^{\circ} \mathrm{F}\right)$ PFBC process gas environment.

Typically the Pall iron aluminide and USF, Fairey Microfiltrex, and Technetics Fecralloy media are identified to be oxidatively stable under gas phase alkali-free, $650^{\circ} \mathrm{C}\left(1200^{\circ} \mathrm{F}\right), 760^{\circ} \mathrm{C}$ 
$\left(1400^{\circ} \mathrm{F}\right)$, and $815-840^{\circ} \mathrm{C}\left(1500-1550^{\circ} \mathrm{F}\right) \mathrm{PFBC}$ process operating conditions. Extended exposure at $840^{\circ} \mathrm{C}\left(1550^{\circ} \mathrm{F}\right)$ beyond 1000 hours of simulated PFBC testing will be required to demonstrate both continued oxidative stability, and potential commercial use of these materials. Both the Fairey Microfiltrex and Technetics elements, however, require structural modifications to be made to the filter architecture (i.e., absence of seam welds and mid-body joiner rings) to assure component integrity during extended commercial use in hot gas filtration applications. Similarly closure of the open porosity along the o.d. and i.d. surfaces of both filter elements through the application of a thin less porous membrane is recommended to prevent capture and retention of ash fines within the sinter bonded fibrous architecture which could ultimately lead to blinding and restricted gas flow through the porous filter media.

As shown in Table 8, the USF Haynes 230, Haynes 214, and Haynes 188 filter media are identified for short-term use in a $650^{\circ} \mathrm{C}\left(1200^{\circ} \mathrm{F}\right) \mathrm{PFBC}$ process gas environment. Concern is expressed for use of these materials in higher temperature PFBC applications. As a result of the physical instability of the filtration mat, as well as extensive oxidation at high temperature, initial or short-term use at $650^{\circ} \mathrm{C}\left(1200^{\circ} \mathrm{F}\right)$ is identified for the USF Haynes 556 filter media.

Sinter bonded Hastelloy X fibers or particles used to manufacture the USF and Pall filter elements exhibited temperature stability at $650^{\circ} \mathrm{C}\left(1200^{\circ} \mathrm{F}\right)$ during the initial 500 hours of simulated PFBC testing. Oxidation and localized pore closure of the Hastelloy $\mathrm{X}$ filter media limits extended use of both filter elements at $\mathrm{PFBC}$ temperatures $\geq 760^{\circ} \mathrm{C}\left(\geq 1400^{\circ} \mathrm{F}\right)$.

When sinter bonded as a fibrous matrix, the USF Inconel 600 filtration media exhibited only short-term stability in the $650-840^{\circ} \mathrm{C}\left(1200-1550^{\circ} \mathrm{F}\right)$ simulated $\mathrm{PFBC}$ process gas environment. In contrast, the heavier, thicker walled, sinter bonded particle, Mott Inconel 600 filter element was identified for use at $650-760^{\circ} \mathrm{C}\left(1200-1400^{\circ} \mathrm{F}\right)$, with only short-term use at $815-840^{\circ} \mathrm{C}$ $\left(1500-1550^{\circ} \mathrm{F}\right)$.

Both the USF and Pall 310S filtration media exhibited short-term stability in the $650^{\circ} \mathrm{C}$ $\left(1200^{\circ} \mathrm{F}\right)$ simulated PFBC process operating environment. Fracture of the Pall $310 \mathrm{~S}$ metal matrix resulted with extended operation at temperatures $\geq 760^{\circ} \mathrm{C}\left(\geq 1400^{\circ} \mathrm{F}\right)$, and extensive oxidation and pore closure of the USF 310 S filtration media resulted at $760-840^{\circ} \mathrm{C}\left(1400-1550^{\circ} \mathrm{F}\right)$. Neither the Pall nor USF 310S filtration media is recommended for extended use in the PFBC process gas environment.

In general, limited sulfur sorption into the various porous metal media was observed during conduct of the simulated PFBC test program. Retention of the sinter bonds between adjoining fibers, particles, or contained structural support mesh layers was observed during the initial 1000 hours of simulated PFBC testing. Crack formations and removal of the oxide layer(s) that encapsulated the Haynes 188, Hastelloy X, Inconel 600, and 310S sinter bonded fibers and particles were identified particularly along the i.d. or pulse cycled surface of the USF, Pall, and Mott filter elements.

In summary, from the series of ten commercial metal, advanced alloy, and intermetallic materials assessed during conduct of this program, porous sinter bonded FeAl and Fecralloy are identified as candidate materials for construction of metal filter elements for installation and potential extended operation in high temperature, gas phase alkali-free, PFBC applications. 


\subsection{ACKNOWLEDGMENTS}

We wish to acknowledge Mr. Richard Dunst and Mr. Ted McMahon at DOE/NETL for their guidance and technical support during conduct of this program. In addition, the efforts of Dr. Thomas Lippert, Dr. Gerald Bruck, Mr. Eugene Smeltzer, Mr. George Schneider, Mr. John Meyer, Mr. Tom Mullen, and Mr. Bob Walko at SWPC STC are acknowledged. The efforts of Dr. Nat Quick and Dr. Alex Sobelevsky at USF, Mr. John Sawyer and Mr. Nelson Sobel at Pall, Dr. Sunil Jha, Mr. Mike Wilson, Dr. Ken Rubow, and Dr. Gary Rawlings at Mott, Mr. Tony McDowell and Mr. Ian Boxall at Fairey Microfiltrex, Mr. Doug Chappel at Technetics, and Mr. Ed Stankiewicz at Ultramet are also acknowledged. 


\subsection{REFERENCES}

1. Filter Assembly for Metallic and Intermetallic Tube Filters, SWPC, US Patent 6,273,925, 8/14/01. 


\section{APPENDIX A}

SUMMARY OF METAL FILTER MEDIA STABILITY UNDER SIMULATED PFBC OPERATING CONDITIONS 


\begin{tabular}{|c|c|c|c|c|c|}
\hline \multirow{2}{*}{ Pall FeAl } & \multicolumn{5}{|c|}{ Simulated PFBC Operating Conditions } \\
\hline & $\begin{array}{c}650^{\circ} \mathrm{C} \\
\left(1200^{\circ} \mathrm{F}\right) \\
242 \text { and } 500 \mathrm{Hrs} \\
\end{array}$ & $\begin{array}{c}760^{\circ} \mathrm{C} \\
\left(1400^{\circ} \mathrm{F}\right) \\
258,524.5 \text {, and } 1016 \mathrm{Hrs} \\
\end{array}$ & $\begin{array}{c}815-840^{\circ} \mathrm{C} \\
\left(1500-15500^{\circ} \mathrm{F}\right) \\
\\
259,476, \text { and } 986 \mathrm{Hrs} \\
\end{array}$ & $\begin{array}{c}840^{\circ} \mathrm{C}\left(1550^{\circ} \mathrm{F}\right) \\
-\mathrm{No} \mathrm{SO}_{2}- \\
253,546.5 \text {, and } 1014 \mathrm{Hrs}\end{array}$ & $\begin{array}{l}840^{\circ} \mathrm{C}\left(1550^{\circ} \mathrm{F}\right) \\
-\mathrm{SO}_{2} \& \mathrm{Na}- \\
225 \text { and } 496 \mathrm{Hrs}\end{array}$ \\
\hline Physical Integrity & Intact & Intact & Intact & Intact & $\begin{array}{c}\text { Failure at weld; Volume expansion; Raised } \\
\text { bubbles; Longitudinal and circumferential } \\
\text { distortion within } 225 \text { hrs }\end{array}$ \\
\hline Open Porosity* & Retained & Retained & Retained & Retained & $\begin{array}{l}\text { Internal pore closure after } \\
225 \mathrm{hrs} \text {; Formation of a densified } \sim 20-60 \mu \mathrm{m} \\
\text { FeO o.d/i.d. layer }\end{array}$ \\
\hline Surface Oxidation* & $\begin{array}{c}\sim 0.2 \mu \mathrm{m} \text { alumina-enriched } \\
\text { after } 500 \mathrm{hrs}\end{array}$ & $\begin{array}{c}\quad \sim 0.5-0.6 \mu \mathrm{m} \\
\text { alumina-enriched after } 1016 \mathrm{hrs}\end{array}$ & $\begin{array}{c}0.2-0.3 \mu \mathrm{m} \\
\text { alumina-enriched after } \\
986 \mathrm{hrs}\end{array}$ & $\begin{array}{c}\sim 0.5 \mu \mathrm{m} \\
\text { alumina-enriched after } \\
1014 \mathrm{hrs}\end{array}$ & Extensive oxidation after $225 \mathrm{hrs}$ \\
\hline Internal Oxidation* & Not observed & Not observed & Not observed & Not observed & Extensive oxidation after $225 \mathrm{hrs}$ \\
\hline $\begin{array}{l}\text { Recommendation for } \\
\text { PFBC Use }\end{array}$ & Yes & Yes & Yes & Yes & No \\
\hline
\end{tabular}

* Based on SEM/EDX analyses. 


\begin{tabular}{|c|c|c|c|c|c|}
\hline \multirow{2}{*}{$\begin{array}{l}\text { Microfiltrex } \\
\text { Fecralloy }\end{array}$} & \multicolumn{5}{|c|}{ Simulated PFBC Operating Conditions } \\
\hline & $\begin{array}{c}650^{\circ} \mathrm{C} \\
\left(1200^{\circ} \mathrm{F}\right) \\
242 \text { and } 500 \mathrm{Hrs}\end{array}$ & $\begin{array}{c}760^{\circ} \mathrm{C} \\
\left(1400^{\circ} \mathrm{F}\right) \\
258,524.5 \text {, and } 1016 \mathrm{Hrs}\end{array}$ & $\begin{array}{c}815-840^{\circ} \mathrm{C} \\
\left(1500-15500^{\circ} \mathrm{F}\right) \\
259,476 \text {, and } 986 \mathrm{Hrs}\end{array}$ & $\begin{array}{c}840^{\circ} \mathrm{C}\left(1550^{\circ} \mathrm{F}\right) \\
-\mathrm{No} \mathrm{SO}_{2}- \\
253,546.5 \text {, and } 1014 \mathrm{Hrs}\end{array}$ & $\begin{array}{l}840^{\circ} \mathrm{C}\left(1550^{\circ} \mathrm{F}\right) \\
-\mathrm{SO}_{2} \& \mathrm{Na}- \\
225 \text { and } 496 \mathrm{Hrs}\end{array}$ \\
\hline Physical Integrity & Intact & Intact & Intact & Intact & $\begin{array}{l}\text { Failure of the external Hast C276 mesh; } \\
\text { Localized removal of filtration mat within } \\
225 \text { hrs }\end{array}$ \\
\hline Open Porosity* & Retained & Retained & Retained & Retained & $\begin{array}{l}\text { Extensive pore closure along the external } \\
\text { surface of the filter element }\end{array}$ \\
\hline Surface Oxidation* & $\begin{array}{l}\text { Limited surface oxidation of } \\
\text { the } \sim 9-12 \mu \mathrm{m} \text { outer surface } \\
\text { fibers, and } \sim 15-30 \mu \mathrm{m} \text { inner } \\
\text { surface fibers } \\
\text { Enrichment of aluminium and } \\
\text { oxygen along the external } \\
\text { surface of the fibers after } \\
500 \mathrm{hrs}\end{array}$ & $\begin{array}{c}\text { Limited surface oxidation of the } \\
\sim 9-12 \mu \mathrm{m} \text { outer surface fibers, } \\
\text { and } \sim 15-30 \mu \mathrm{m} \text { inner surface } \\
\text { fibers } \\
\text { Fine fibers: } \\
\sim 0.7 \mu \mathrm{m} \text { after } 258-1016 \mathrm{hrs} ; \\
\text { Initially FeO/CC-Al formed; } \\
\text { Subsurface FeO/AlO formed with } \\
\text { time. After } 1016 \mathrm{hr}, \text { iron } \\
\text { aluminate resulted } \\
\text { Coarse fibers: } \\
\sim 0.3-0.7 \mu \mathrm{m} \text { oxide formed, } \\
\text { increasing with extended time; } \\
\text { Initially FeO/AlO resulted; } \\
\text { With time the concentration of Fe } \\
\text { decreased while Al increased }\end{array}$ & $\begin{array}{c}\text { Limited surface oxidation } \\
\text { Fine fibers: } \\
\sim 0.3-0.5 \mu \mathrm{m} \text { oxide } \\
\text { Fe-Al-O after } 259 \mathrm{hrs} \\
\text { Al-Fe-O after } 986 \mathrm{hrs} \\
\\
\text { Coarse fibers: } \\
\sim 0.2-0.6 \mu \mathrm{m} \\
\text { Fe-Al-O after } 259 \mathrm{hrs} \\
\text { Al-Fe-O after } 986 \mathrm{hrs}\end{array}$ & $\begin{array}{c}\text { Limits surface oxidation } \\
\text { Fine fibers: } \\
\sim 0.2-0.5 \mu \mathrm{m} \\
\text { Fe-Al-O after } 253 \mathrm{hrs} \\
\text { Al-Fe-O after } 1-14 \mathrm{hrs} \\
\text { Coarse fibers: } \\
\sim 0.2-1.5 \mu \mathrm{m} \\
\text { Al-Fe-O }\end{array}$ & $\begin{array}{l}\text { Extensive oxidation and densification along } \\
\text { the outer surface of the filtration mat; } \\
\text { Iron oxide phases resulted } \\
\text { As isolated fine fibers: } \\
\text { Fe-Al-O } \\
\text { Coarse fibers: } \\
\text { Alumina, } \mathrm{FeO}\end{array}$ \\
\hline Internal Oxidation* & Not observed & Not observed & Not observed & Not observed & $\begin{array}{c}\text { Extensive internal oxidation within fibers } \\
\text { present along outer filtration mat; } \\
\text { Absence of internal oxidation within discrete } \\
\text { internal fibers }\end{array}$ \\
\hline $\begin{array}{c}\text { Recommendation for } \\
\text { PFBC Use }\end{array}$ & Yes & Yes & Yes & Yes & No \\
\hline
\end{tabular}

* Based on SEM/EDX analyses. 


\begin{tabular}{|c|c|c|c|c|c|}
\hline \multirow{2}{*}{$\begin{array}{l}\text { Technetics } \\
\text { Fecralloy }\end{array}$} & \multicolumn{5}{|c|}{ Simulated PFBC Operating Conditions } \\
\hline & $\begin{array}{c}6^{50^{\circ}} \mathrm{C} \\
\left(1200^{\circ} \mathrm{F}\right) \\
242 \text { and } 500 \text { Hrs } \\
\end{array}$ & $\begin{array}{c}760^{\circ} \mathrm{C} \\
\left(1400^{\circ} \mathrm{F}\right) \\
258,524.5, \text { and } 1016 \mathrm{Hrs} \\
\end{array}$ & $\begin{array}{c}815-840^{\circ} \mathrm{C} \\
(1500-1550 \\
\end{array}$ & $\begin{array}{c}840^{\circ} \mathrm{C}\left(1550^{\circ} \mathrm{F}\right) \\
-\mathrm{No} \mathrm{SO}_{2}- \\
253,546.5, \text { and } 1014 \mathrm{Hrs}\end{array}$ & $\begin{array}{l}840^{\circ} \mathrm{C}\left(15500^{\circ} \mathrm{F}\right) \\
-\mathrm{SO}_{2} \& \mathrm{Na}- \\
225 \text { and } 496 \mathrm{Hrs}\end{array}$ \\
\hline Physical Integrity & Intact & Intact & Intact & Intact & $\begin{array}{l}\text { Continuity of the longitudinal weld in } \\
\text { question }\end{array}$ \\
\hline Open Porosity* & Retained & Retained & Retained & Retained & $\begin{array}{l}\text { Extensive pore closure along the external } \\
\text { surface of the filter element }\end{array}$ \\
\hline Surface Oxidation* & $\begin{array}{l}\text { Limited } \\
\text { Aluminum enriched along the } \\
\text { external surface of the fibers } \\
\text { after } 500 \mathrm{hrs}\end{array}$ & $\begin{array}{c}\text { Limited } \\
\text { Shaved fibers: } \\
\sim 0.13 \mu \mathrm{m} \mathrm{Fe}-\mathrm{O} \text { after } 258 \mathrm{hrs} \\
\sim 0.5-0.8 \mu \mathrm{m} \text { Fe-Al-O after } \\
1016 \mathrm{hrs} \\
\\
\text { Support fibers: } \\
\sim 0.2-0.6 \mu \mathrm{m} \\
\text { Fe-Al-O }\end{array}$ & $\begin{array}{c}\text { Surface oxidation } \\
\\
\text { Shaved fibers: } \\
\sim 0.5-1.0 \mu \mathrm{m} \\
\text { Alumina, Al-Fe-O } \\
\\
\\
\text { Support fibers: } \\
\sim 0.66-2.2 \mu \mathrm{m} \\
\text { Alumina, minor FeO }\end{array}$ & $\begin{array}{c}\text { Surface oxidation } \\
\\
\text { Shaved fibers: } \\
\sim 0.2-0.4 \mu \mathrm{m} \\
\text { Fe-Al-O after } 253 \mathrm{hrs} \\
\text { Alumina after } 546.5 \mathrm{hrs} \\
\\
\text { Support fibers: } \\
\sim 0.13 \mu \mathrm{m} \\
\text { Fe-O after } 253 \mathrm{hrs} \\
\text { Fe-Al-O after } 546.5 \mathrm{hrs}\end{array}$ & $\begin{array}{c}\text { Extensive surface oxidation; } \\
\text { Volume expansion of fibers; } \\
\text { Penetration into 1/2 of the filtration metal } \\
\text { thickness } \\
\text { Shaved fibers: } \\
\text { Fe-O resulted along the outer surface } \\
\text { Cr-Fe-O resulted within the base metal } \\
\text { Support fibers: } \\
\text { Al/Fe-O atter } 225 \text { hrs } \\
\text { Alumina or chromia after } 496 \mathrm{hrs}\end{array}$ \\
\hline Internal Oxidation* & Not observed & Not observed & Not observed & Not observed & $\begin{array}{c}\text { Extensive internal oxidation within fibers } \\
\text { present along outer filtration mat; } \\
\text { Absence of internal oxidation within discrete } \\
\text { internal fibers } \\
\end{array}$ \\
\hline $\begin{array}{c}\text { Recommendation for } \\
\text { PFBC Use }\end{array}$ & Yes & Yes & Yes & Yes & No \\
\hline
\end{tabular}

* Based on SEM/EDX analyses. 


\begin{tabular}{|c|c|c|c|c|c|}
\hline \multirow{2}{*}{$\begin{array}{c}\text { USF Fecralloy } \\
\text { Hoskins } 875 \text { fibers: } \\
\text { Fe Bal; } 22.5 \% \mathrm{Cr}, 5.5 \% \mathrm{Al} \\
0.5 \% \mathrm{Si}, 0.1 \% \mathrm{C}\end{array}$} & \multicolumn{5}{|c|}{ Simulated PFBC Operating Conditions } \\
\hline & $\begin{array}{c}6^{650}{ }^{\circ} \mathrm{C} \\
\left(1200^{\circ} \mathrm{F}\right) \\
242 \text { and } 500 \mathrm{Hrs} \\
\end{array}$ & $\begin{array}{c}\mathbf{7 6 0}^{\circ} \mathrm{C} \\
\left(1400^{\circ} \mathrm{F}\right) \\
258,524.5 \text {, and } 1016 \mathrm{Hrs} \\
\end{array}$ & 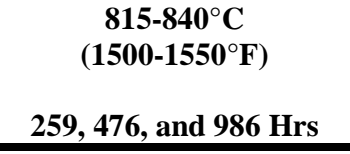 & $\begin{array}{c}840^{\circ} \mathrm{C}\left(1550^{\circ} \mathrm{F}\right) \\
-\mathrm{No} \mathrm{SO}_{2}- \\
253,546.5 \text {, and } 1014 \mathrm{Hrs}\end{array}$ & $\begin{array}{l}8^{440}{ }^{\circ} \mathrm{C}(1550 \\
-\mathrm{SO}_{2} \& \mathrm{Na}- \\
225 \text { and } 496 \mathrm{Hrs}\end{array}$ \\
\hline Physical Integrity & $\begin{array}{c}\text { Transverse linear indications } \\
\text { and through-cracks along } \\
\text { longitudinal weld seam after } \\
242 \text { hrs; } \\
\text { Section removed and media } \\
\text { was modified } \\
\end{array}$ & Intact & Intact & Intact & Intact; Densified external surface ( $496 \mathrm{hrs)}$ \\
\hline Open Porosity* & Retained & Retained & Retained & Retained & $\begin{array}{l}\text { Limited retention after } 225 \mathrm{hrs} \\
\text { Pore closure after } 496 \mathrm{hrs}\end{array}$ \\
\hline Surface Oxidation* & $\begin{array}{l}\sim 0.1 \mu \mathrm{m} \text { alumina-enriched } \\
\text { after } 500 \mathrm{hrs}\end{array}$ & $\begin{array}{l}\sim 0.2-0.5 \mu \mathrm{m} \text { alumina-enriched } \\
\text { after } 1016 \mathrm{hrs}\end{array}$ & $\begin{array}{c}\sim 1-2 \mu \mathrm{m} \text { discontinuous } \\
\text { alumina, iron oxide, chromia } \\
\text { layer after } 986 \mathrm{hrs}\end{array}$ & $\begin{array}{l}<1.1 \mu \mathrm{m} \text { discontinuous } \\
\text { alumina, iron oxide, chromia } \\
\text { layer after } 1014 \text { hrs }\end{array}$ & $\begin{array}{c}\sim 2-3 \mu \mathrm{m} \text { alumina needle-like whiskers after } \\
225 \mathrm{hrs;} \\
\text { Extensive oxidation after } 496 \mathrm{hrs} \\
\end{array}$ \\
\hline Internal Oxidation* & Not observed & Not observed & Not observed & Not observed & Extensive oxidation after $496 \mathrm{hrs}$ \\
\hline $\begin{array}{l}\text { Recommendation for } \\
\text { PFBC Use }\end{array}$ & Yes & Yes & Yes & Yes & No \\
\hline
\end{tabular}

* Based on SEM/EDX analyses. 


\begin{tabular}{|c|c|c|c|c|c|}
\hline \multirow{2}{*}{$\begin{array}{c}\text { USF Haynes } 230 \\
\\
57 \% \mathrm{Ni}, 22 \% \mathrm{Cr}, 14 \% \mathrm{~W}, \\
5 \% \mathrm{Co}, 3 \% \mathrm{Fe}, 0.1 \% \mathrm{C}, \\
0.4 \% \mathrm{Si}, 0.5 \% \mathrm{Mn}, \\
0.02 \% \mathrm{La}, 0.015 \% \mathrm{~B} \\
2 \% \mathrm{Mo}, 0.3 \% \mathrm{Al} \\
\end{array}$} & \multicolumn{5}{|c|}{ Simulated PFBC Operating Conditions } \\
\hline & $\begin{array}{c}650^{\circ} \mathrm{C} \\
\left(1200^{\circ} \mathrm{F}\right) \\
242 \text { and } 500 \text { Hrs } \\
\end{array}$ & $\begin{array}{c}760^{\circ} \mathrm{C} \\
\left(1400^{\circ} \mathrm{F}\right) \\
258,524.5 \text {, and } 1016 \mathrm{Hrs}\end{array}$ & $\begin{array}{c}815-840^{\circ} \mathrm{C} \\
\left(1500-1550^{\circ} \mathrm{F}\right) \\
259,476, \text { and } 986 \mathrm{Hrs}\end{array}$ & $\begin{array}{c}840^{\circ} \mathrm{C}\left(1550^{\circ} \mathrm{F}\right) \\
-\mathrm{No} \mathrm{SO}_{2}- \\
253,546.5 \text {, and } 1014 \mathrm{Hrs}\end{array}$ & $\begin{array}{l}840^{\circ} \mathrm{C}\left(1550^{\circ} \mathrm{F}\right) \\
-\mathrm{SO}_{2} \& \mathrm{Na}- \\
225 \text { and } 496 \mathrm{Hrs}\end{array}$ \\
\hline Physical Integrity & Intact & Intact & Intact & Intact & $\begin{array}{c}\text { Intact } \\
\text { Densified external surface (496 hrs) }\end{array}$ \\
\hline Open Porosity* & Retained after $500 \mathrm{hrs}$ & $\begin{array}{l}\text { Retained after } 258 \mathrm{hrs} \\
\text { Limited after } 524.5 \text { and } 1016 \mathrm{hrs}\end{array}$ & $\begin{array}{l}\text { Retained after } 259 \mathrm{hrs} \\
\text { Limited after } 986 \mathrm{hrs}\end{array}$ & $\begin{array}{c}\text { Limited after } 253 \mathrm{hrs} \\
\text { Closure of pores resulted after } \\
546.5 \text { and } 1014 \mathrm{hrs} \\
\end{array}$ & $\begin{array}{l}\text { Limited after } 225 \text { hours; } \\
\text { Closure of pores after } 496 \mathrm{hrs}\end{array}$ \\
\hline Surface Oxidation* & $\begin{array}{l}\sim 2.5-3 \mu \mathrm{m} \mathrm{O} \text { O-Cr-Ni (Fe) spinel } \\
\text { after } 500 \mathrm{hrs}\end{array}$ & $\begin{array}{c}\text { External } \sim 3-5.5 \mu \mathrm{m} \mathrm{NiO} \mathrm{layer} \\
\text { formed; } \\
\text { With time, underlying subsurface } \\
\text { oxide transitioned from } \\
\text { O-Cr-Ni-based layer to a chromia- } \\
\text { enriched layer }\end{array}$ & $\begin{array}{l}\text { Initially fibers were } \\
\text { encapsulated with an external } \\
\text { chromia-enriched layer, and a } \\
\text { subsurface chrome-nickel } \\
\text { oxide layer } \\
\text { After } 476 \mathrm{hrs} \text {, chromia was } \\
\text { identified as the primary } \\
\text { oxide phase } \\
\text { After } 986 \mathrm{hr} \text {, an } \sim 1.5-6 \mu \mathrm{m} \\
\text { Fe-Ni oxide spinel or NiO } \\
\text { layer formed }\end{array}$ & $\begin{array}{c}\text { With continued exposure time, } \\
\text { the thickness of the surface } \\
\text { oxide layer tended to increase: } \\
\sim 1.5 \mu \mathrm{m} \text { at } 253 \mathrm{hrs} ; \\
\sim 5.5 \mu \mathrm{m} \text { at } 546.5 \mathrm{hrs} \\
\sim 2.5-15 \mu \mathrm{m} \text { at } 1014 \mathrm{hrs} \\
\\
\text { Initially an external chromia } \\
\text { and subsurface O-Cr-Ni spinel } \\
\text { formed; With time, a Ni- } \\
\text { enriched outer surface resulted } \\
\text { with an underlying } \\
\text { O-Ni-Fe-Cr-enriched } \\
\text { subsurface layer }\end{array}$ & $\begin{array}{c}\text { Thickness of the external oxide layer } \\
\text { increased with time: } \\
\sim 1-25 \mu \mathrm{m} \text { after } 225 \mathrm{hrs} \\
\sim 25-50 \mu \mathrm{m} \text { after } 496 \mathrm{hrs} \\
\\
\text { Outer surface layer after } 225 \text { and } 496 \mathrm{hrs} \text { was } \\
\text { enriched with Ni and O; } \\
\text { Subsurface oxides consisted of O-Cr-Ni-Fe } \\
\text { phases }\end{array}$ \\
\hline Internal Oxidation* & $\begin{array}{c}\text { Internal oxidation between } \\
\text { adjacent fibers resulted after } \\
500 \mathrm{hrs}\end{array}$ & $\begin{array}{l}\text { Intragranular oxidation resulted } \\
\text { within fibers, between sinter } \\
\text { bonded fibers, and at the } \\
\text { fiber/structural mesh support } \\
\text { interface } \\
\text { Void formations at the fiber } \\
\text { oxide/base metal interface were } \\
\text { observed }\end{array}$ & $\begin{array}{c}\text { Intragranular oxidation } \\
\text { resulted within fibers; } \\
\text { Oxidation resulted between } \\
\text { sinter bonded fibers } \\
\text { Void formations at the fiber } \\
\text { oxide/base metal interface } \\
\text { resulted; Void formations } \\
\text { became more pronounced } \\
\text { with continued exposure time } \\
\end{array}$ & $\begin{array}{c}\text { After } 253 \mathrm{hrs} \text {, void formations } \\
\text { and internal oxidation were } \\
\text { evident }\end{array}$ & $\begin{array}{l}\text { Internal oxidation and numerous voids were } \\
\text { observed after } 225 \text { hrs }\end{array}$ \\
\hline $\begin{array}{l}\text { Recommendation for } \\
\text { PFBC Use }\end{array}$ & Acceptable for short-term use & $\begin{array}{l}\text { Not recommended for long-term } \\
\text { use }\end{array}$ & $\begin{array}{l}\text { Not recommended for long- } \\
\text { term use }\end{array}$ & $\begin{array}{l}\text { Not recommended for long- } \\
\text { term use }\end{array}$ & No \\
\hline
\end{tabular}

* Based on SEM/EDX analyses. 


\begin{tabular}{|c|c|c|c|c|c|}
\hline \multirow{2}{*}{$\begin{array}{c}\text { USF Haynes } 214 \\
\\
75 \% \mathrm{Ni}, 16 \% \mathrm{Cr}, \\
3 \% \mathrm{Fe}, 0.05 \% \mathrm{C}, \\
0.2 \% \mathrm{Si}, 0.5 \% \mathrm{Mn}, 0.01 \% \mathrm{~B}, \\
4.5 \% \mathrm{Al}, 0.1 \% \mathrm{Zr}, 0.01 \% \mathrm{Y} \\
\end{array}$} & \multicolumn{5}{|c|}{ Simulated PFBC Operating Conditions } \\
\hline & $\begin{array}{c}\mathbf{6 5 0}^{\circ} \mathrm{C} \\
\left(1200^{\circ} \mathrm{F}\right) \\
242 \text { and } 500 \mathrm{Hrs} \\
\end{array}$ & $\begin{array}{c}760^{\circ} \mathrm{C} \\
\left(1400^{\circ} \mathrm{F}\right) \\
\\
258,524.5 \text {, and } 1016 \mathrm{Hrs}\end{array}$ & 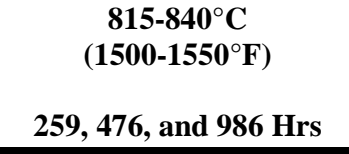 & $\begin{array}{c}\mathbf{8 4 0}^{\circ} \mathrm{C}\left(1550^{\circ} \mathrm{F}\right) \\
\text { - } \mathrm{No} \mathrm{SO}_{2}- \\
253,546.5 \text {, and } 1014 \mathrm{Hrs}\end{array}$ & $\begin{array}{l}8^{440}{ }^{\circ} \mathrm{C}(1550 \\
-\mathrm{SO}_{2} \& \mathrm{Na}- \\
225 \text { and } 496 \mathrm{Hrs}\end{array}$ \\
\hline Physical Integrity & Intact & Intact & Intact & Intact & $\begin{array}{l}\text { Removal of the filtration media and outer } \\
\text { mesh within } 496 \text { hrs }\end{array}$ \\
\hline Open Porosity* & Retained after $500 \mathrm{hrs}$ & Retained after 1016 hrs & $\begin{array}{c}\text { Retained after } 259 \mathrm{hrs;} \\
\text { Limited after } 476 \text { and } 986 \mathrm{hrs} \\
\end{array}$ & $\begin{array}{c}\text { Retained after } 253 \mathrm{hrs;} \text { Limited } \\
\text { after } 1014 \mathrm{hrs}\end{array}$ & $\begin{array}{c}\text { Limited with pore closure after } 225 \text { hrs; Pore } \\
\text { closure after } 496 \text { hrs }\end{array}$ \\
\hline Surface Oxidation* & $\begin{array}{l}0.5-1.5 \mu \mathrm{m} \text { chromia/ O-Cr-Fe } \\
\text { spinel; } \\
\text { Minor sulfur sorption after } \\
500 \mathrm{hrs}\end{array}$ & $\begin{array}{c}\text { Multiple layers: } \\
\sim 2-5 \mu \mathrm{m} \\
\text { After } 258 \mathrm{hrs:} \\
\text { External O-Ni-(Cr) } \\
\text { Internal O-Cr-Ni layer formed } \\
\text { After } 524.5 \mathrm{hrs:} \\
\text { External: Chromia-Ni } \\
\text { Sublayer/particles: } \\
\text { O-Ni-Cr-(Al) } \\
\text { Adjacent to substrate: } \\
\text { O-Ni-Al-(Cr) } \\
\text { After } 1016 \text { hrs: } \\
\text { External: Chromia-Ni } \\
\text { Sublayer/particles: } \\
\text { O-Ni-Cr-(Al) } \\
\text { Adjacent to substrate: } \\
\text { O-Cr-Ni-(Al) } \\
\text { Sinter bond between adjacent } \\
\text { fibers appeared to be retained }\end{array}$ & $\begin{array}{c}\text { Multiple layers: } \\
\sim 3-10 \mu \mathrm{m} \\
\text { After } 259 \mathrm{hrs:} \\
\text { External: } \mathrm{NiO} \\
\text { Subsurface: } \mathrm{O}-\mathrm{Cr}-\mathrm{Ni}(\mathrm{Al}) \\
\text { Adjacent to substrate: } \\
\text { O-Cr-(Ni-Al) } \\
\text { After } 476 \mathrm{hrs:} \\
\text { External: } \mathrm{NiO}-(\mathrm{Fe}) \\
\text { Subsurface: } \mathrm{O}-\mathrm{Ni}-\mathrm{Fe}-\mathrm{Cr} \\
\text { Adjacent to substrate: } \\
\text { Chromia-Ni } \\
\text { After } 986 \mathrm{hrs:} \\
\text { External: Chromia }\end{array}$ & $\begin{array}{c}\text { Multiple layers: } \\
\sim 3.4->14 \mu \mathrm{m} \\
\text { After } 253 \mathrm{hrs:} \\
\text { External: } \mathrm{Chromia} \\
\text { Subsurface: } \mathrm{NiO}-(\mathrm{Cr}) \\
\text { Interface: } \\
\text { O-Ni-Cr-(Al) } \\
\text { After } 546.5 \mathrm{hrs} \\
\text { External: NiO-(Fe-Cr) } \\
\text { Subsurface: } \mathrm{O}-\mathrm{Cr}-\mathrm{Ni} \\
\text { Adjacent to substrate: } \\
\text { O-Ni-(Cr) } \\
\text { Extensive oxidation after } \\
1014 \text { hrs }\end{array}$ & $\begin{array}{l}\text { Thickness of the external oxide layer } \\
\text { increased with time: } \\
4-16 \mu \mathrm{m} \text { after } 225 \mathrm{hrs} \\
>18 \mu \mathrm{m} \text { after } 496 \text { hrs with pore closure } \\
\text { After } 225 \mathrm{hrs:} \\
\text { External: O-Cr-Ni-Fe } \\
\text { Subsurface: Chromia-(Ni) } \\
\text { Adjacent to substrate: O-Cr-Ni-S-(Al) } \\
\text { After } 496 \mathrm{hrs:} \\
\text { External: NiO-(Fe) } \\
\text { Subsurface: Fe-Ni-O } \\
\text { Interface: Chromia-(Ni-Fe) }\end{array}$ \\
\hline Internal Oxidation* & $\begin{array}{l}\text { Pitting observed along the } \\
\text { external surface of the fibers; } \\
\text { Void formations observed } \\
\text { along the sinter bond interface } \\
\text { between adjacent fibers }\end{array}$ & $\begin{array}{l}\text { Significant internal oxidation } \\
\text { along the periphery of the fibers } \\
\text { penetrating to depths of } \sim 4-8 \mu \mathrm{m}\end{array}$ & $\begin{array}{l}\text { Significant internal oxidation } \\
\text { initially along the periphery } \\
\text { of the fibers penetrating to } \\
\text { depths of } \sim 13-16 \mu \mathrm{m} \text { after } \\
259 \mathrm{hrs} \text {; Oxidation observed } \\
\text { throughout the cross- } \\
\text { sectioned fibers after } 986 \mathrm{hrs} \\
\end{array}$ & $\begin{array}{c}\text { Significant internal oxidation } \\
\text { along the entire cross-sectioned } \\
\text { fiber surface }\end{array}$ & $\begin{array}{l}\text { Significant internal oxidation along the entire } \\
\text { cross-sectioned fiber surface }\end{array}$ \\
\hline $\begin{array}{l}\text { Recommendation for } \\
\text { PFBC Use }\end{array}$ & Acceptable for short-term use & $\begin{array}{c}\text { Possible use; } \\
\text { Integrity of the fibers questioned }\end{array}$ & $\begin{array}{l}\text { Integrity of the fibers } \\
\text { questioned }\end{array}$ & $\begin{array}{l}\text { Integrity of the fibers } \\
\text { questioned }\end{array}$ & No \\
\hline
\end{tabular}




\begin{tabular}{|c|c|c|c|c|c|}
\hline \multirow{2}{*}{$\begin{array}{c}\text { USF Haynes } 188 \\
\text { Co Bal; } 21-23 \% \mathrm{Cr}, \\
20-24 \% \mathrm{Ni}, 13-15 \% \mathrm{~W}, \\
3 \% \mathrm{Fe}, 0.05-0.15 \% \mathrm{C}, \\
0.2-0.5 \% \mathrm{Si}, 1.25 \% \mathrm{Mn}, \\
0.03-0.12 \% \mathrm{La}, 0.015 \% \mathrm{~B} \\
\end{array}$} & \multicolumn{5}{|c|}{ Simulated PFBC Operating Conditions } \\
\hline & $\begin{array}{c}650^{\circ} \mathrm{C} \\
\left(1200^{\circ} \mathrm{F}\right) \\
242 \text { and } 500 \mathrm{Hrs}\end{array}$ & $\begin{array}{c}760^{\circ} \mathrm{C} \\
\left(1400^{\circ} \mathrm{F}\right) \\
258,524.5 \text {, and } 1016 \mathrm{Hrs}\end{array}$ & $\begin{array}{c}815-840^{\circ} \mathrm{C} \\
\left(1500-1550^{\circ} \mathrm{F}\right) \\
259,476, \text { and } 986 \mathrm{Hrs}\end{array}$ & $\begin{array}{c}8^{840} 0^{\circ} \mathrm{C}\left(1550^{\circ} \mathrm{F}\right) \\
-\mathrm{No} \mathrm{SO}_{2}- \\
253,546.5, \text { and } 1014 \mathrm{Hrs}\end{array}$ & $\begin{array}{l}840^{\circ} \mathrm{C}\left(1550^{\circ} \mathrm{F}\right) \\
-\mathrm{SO}_{2} \& \mathrm{Na}- \\
225 \text { and } 496 \mathrm{Hrs}\end{array}$ \\
\hline Physical Integrity & Intact & Intact & Intact & Intact & $\begin{array}{l}\text { Expansion and separation of filtration media } \\
\text { radiating from the circumferentially welded } \\
\text { metal joiner rings within } 496 \text { hrs (i.e., } \\
\text { elephant foot formation); Longitudinal cracks } \\
\text { within filter media } \\
\end{array}$ \\
\hline Open Porosity* & Retained after $500 \mathrm{hrs}$ & $\begin{array}{c}\text { Retained after } 258 \text { and } \\
524.5 \text { hrs; Slight reduction after } \\
1016 \text { hrs } \\
\end{array}$ & $\begin{array}{l}\text { Retained after } 259 \text { hrs; Reduced } \\
\text { after } 476 \text { hrs; Pore closure after } \\
986 \text { hrs }\end{array}$ & $\begin{array}{l}\text { Retained after } 253 \text { and } 546.5 \mathrm{hrs;} \\
\text { Limited after } 1014 \mathrm{hrs}\end{array}$ & Pore closure after $225 \mathrm{hrs}$ \\
\hline Surface Oxidation* & $\begin{array}{c}\text { Multiple layers: } \\
\sim 1-2 \mu \mathrm{m} \\
\sim 1 \mu \mathrm{m} \text { external } \\
\text { O-Cr-Co or O-Cr-Fe } \\
\text { layer; } \\
\sim 1 \mu \mathrm{m} \text { chromia } \\
\text { subsurface layer after } \\
500 \mathrm{hrs}\end{array}$ & $\begin{array}{c}\text { Multiple oxide layers formed; } \\
\text { Crack formations evident with } \\
\text { removal of material; Separation } \\
\text { of the oxide from the base metal } \\
\text { substrate } \\
\text { After } 258 \mathrm{hrs}: \\
2.4-8 \mu \mathrm{m} \text { oxide } \\
\text { External: O-Fe-Co-Cr } \\
\text { Subsurface: O-(Co-Cr)-(Fe-Ni) } \\
\text { Adjacent to substrate: Chromia } \\
\text { After } 524.5 \mathrm{hrs:} \\
\sim 3-6 \mu \mathrm{m} \\
\text { External: CoO-(Ni-Fe) } \\
\text { Subsurface: } \mathrm{O}-\mathrm{Cr}-\mathrm{Co} \\
\text { Adjacent to substrate: Chromia } \\
\text { After } 1016 \mathrm{hrs:} \\
\sim 6-10 \mu \mathrm{m} \\
\text { External: } \mathrm{O}-\mathrm{Co}-(\mathrm{Ni}-\mathrm{Cr}) \\
\text { Subsurface: } \mathrm{O}-\mathrm{Cr}-\mathrm{Co} \\
\text { Adjacent to substrate: Chromia }\end{array}$ & $\begin{array}{c}\text { Extensive oxidation; } \\
\text { Areas evident where removal of } \\
\text { the oxide resulted } \\
\\
\text { After } 259 \mathrm{hrs:} \\
\sim 4-9.2 \mu \mathrm{m} \\
\text { External: } \mathrm{O}-\mathrm{Cr}-\mathrm{Co}-(\mathrm{Fe}) \\
\text { Subsurface: O-Cr-(Co) } \\
\text { Adjacent to substrate: } \mathrm{O}-\mathrm{Cr} \\
\\
\text { After } 476 \mathrm{hrs:} \\
\sim 10-20 \mu \mathrm{m} \\
\text { External: } \mathrm{O}-\mathrm{Cr}-\mathrm{Co}-\mathrm{Fe} \\
\text { Subsurface: } \mathrm{O}-\mathrm{Cr}-\mathrm{Co} \\
\text { After } 986 \mathrm{hrs:} \\
\sim 12-15 \mu \mathrm{m} \\
\text { External: } \mathrm{O}-\mathrm{Cr}-\mathrm{Co}-\mathrm{Fe} \\
\text { Subsurface: } \mathrm{O}-\mathrm{Cr}-(\mathrm{Co})\end{array}$ & $\begin{array}{c}\text { Extensive oxidation; Crack formations } \\
\text { evident with removal of the oxide } \\
\text { After } 253 \mathrm{hrs:} \sim 0.8-4 \mu \mathrm{m} \\
\text { External: O-Cr } \\
\text { Subsurface: Chromia } \\
\\
\text { After } 546.5 \mathrm{hrs:} \\
\sim 4-11 \mu \mathrm{m} \\
\text { External: O-Cr-Co-(Fe) } \\
\text { Precipitates: O-Cr-Co-(Ni) } \\
\text { Subsurface: } \mathrm{O}-\mathrm{Cr}-(\mathrm{Co}) ; \\
\text { O-Co-(Ni-Cr) } \\
\text { O-Cr-Co } \\
\\
\text { Extensive oxidation after } 1014 \text { hrs: } \\
\sim 7-14 \mu \mathrm{m}\end{array}$ & $\begin{array}{l}\text { Extensive oxidation; Crack formations } \\
\text { evident within the oxide }\end{array}$ \\
\hline Internal Oxidation* & $\begin{array}{l}\text { Internal oxidation } \\
\text { along the surface of } \\
\text { the fibers; Sinter bond } \\
\text { impacted }\end{array}$ & $\begin{array}{l}\text { Oxidation observed between } \\
\text { adjacent sinter bonded fibers } \\
\text { Penetration of oxide } \\
\text { intermittently along the } \\
\text { periphery of the fibers to depths } \\
\text { of } \sim 4-10 \mu \mathrm{m} \text { increases as a } \\
\text { function of time }\end{array}$ & $\begin{array}{l}\text { Intergranular oxidation evident; } \\
\text { Oxidation at sinter bond between } \\
\text { adjacent fibers evident } \\
\text { Oxidation along the periphery of } \\
\text { the fiber base metal substrate } \\
\text { penetrating to depths of } \sim 10 \mu \mathrm{m} \\
\text { after } 259 \mathrm{hrs} ; \sim 8 \mu \mathrm{m} \text { after } 476 \mathrm{hrs} ; \\
\text { and } \sim 20 \mu \mathrm{m} \text { after } 986 \mathrm{hrs} \text {. } \\
\text { Extensive oxidation entirely } \\
\text { throughout the cross-sectioned } \\
\text { fiber after } 986 \mathrm{hrs}\end{array}$ & $\begin{array}{l}\text { After } 253 \text { hrs, intermittent oxidation } \\
\text { resulted along the periphery of the fibers } \\
\text { extending to depths of } \sim 5-7.5 \mu \mathrm{m} \\
\text { After } 546.5 \mathrm{hrs} \text {, significant oxidation was } \\
\text { evident throughout the cross-sectioned } \\
\text { fibers; Also observed were areas with } \\
\text { intermittent oxidation extending to } \\
\text { depths of } \sim 12 \mu \mathrm{m} \\
\text { After } 1014 \text { hrs, extensive oxidation } \\
\text { resulted throughout the cross-sectioned } \\
\text { fibers }\end{array}$ & $\begin{array}{l}\text { After } 225 \mathrm{hrs} \text {, intermittent penetration of } \\
\text { oxide resulted along the periphery of the } \\
\text { fiber to depths of } \sim 4-10 \mu \mathrm{m} \\
\text { After } 496 \mathrm{hrs} \text {, extensive oxidation resulted } \\
\text { throughout the cross-sectioned fibers }\end{array}$ \\
\hline $\begin{array}{c}\text { Recommendation for } \\
\text { PFBC Use }\end{array}$ & Possible use & $\begin{array}{l}\text { Integrity of the fibers } \\
\text { questioned }\end{array}$ & Integrity of the fibers questioned & No & No \\
\hline
\end{tabular}

* Based on SEM/EDX analyses. 


\section{USF Haynes 556}

Fe Bal; $22 \% \mathrm{Cr}, 20 \% \mathrm{Ni}$,

$18 \% \mathrm{Co}, 2.5 \% \mathrm{~W}, 0.1 \% \mathrm{C}$

$0.02 \% \mathrm{La}, 3 \% \mathrm{Mo}, 0.02 \% \mathrm{Z}$ $0.6 \% \mathrm{Ta}$

Simulated PFBC Operating Conditions

\begin{tabular}{|c|c|c|c|c|c|}
\hline $\begin{array}{c}.02 \% \mathrm{La}, 3 \% \mathrm{Mo}, 0.02 \% \mathrm{Zr} \\
0.6 \% \mathrm{Ta}\end{array}$ & 242 and 500 Hrs & 258, 524.5, and 1016 Hrs & 259, 476, and $986 \mathrm{Hrs}$ & 253, 546.5, and $1014 \mathrm{Hrs}$ & 225 and $496 \mathrm{Hrs}$ \\
\hline Physical Integrity & Intact & $\begin{array}{l}\text { Isolated removal of the outer } \\
\text { filtration mat occurred within } \\
1016 \mathrm{hrs}\end{array}$ & $\begin{array}{l}\text { Isolated removal of the outer filtration } \\
\text { mat occurred within } 259 \mathrm{hrs}\end{array}$ & $\begin{array}{l}\text { Isolated removal of the outer } \\
\text { filtration mat occurred within } \\
\qquad 253 \mathrm{hrs}\end{array}$ & $\begin{array}{l}\text { Expansion and separation of filtration } \\
\text { media radiating from the circumferentially } \\
\text { welded metal joiner rings within } 496 \text { hrs } \\
\text { (i.e., elephant foot formation); } \\
\text { Longitudinal cracks within filter media }\end{array}$ \\
\hline Open Porosity* & $\begin{array}{l}\text { Retained after } \\
500 \mathrm{hrs}\end{array}$ & $\begin{array}{l}\text { Retained after } 258 \text { hrs; Limited } \\
\text { after } 524.5 \mathrm{hrs;} \text { Limited with } \\
\text { pore closure after } 1016 \mathrm{hrs} \\
\end{array}$ & $\begin{array}{c}\text { Pore closure limiting porosity after } \\
259 \text { hrs; Continued exposure } \\
\text { enhanced pore closure }\end{array}$ & Pore closure resulted after $253 \mathrm{hrs}$ & Pore closure resulted after $225 \mathrm{hrs}$ \\
\hline Surface Oxidation* & $\begin{array}{c}\text { Multiple layers: } \\
\quad \sim 1-10 \mu \mathrm{m} \\
\text { External O-Fe-Cr } \\
\text { layer; Underlying } \\
\text { chromia-enriched } \\
\text { layer; Through crack } \\
\text { formations observed } \\
\text { within the oxide scale }\end{array}$ & $\begin{array}{c}\text { Multiple layers: } \\
4-12.5 \mu \mathrm{m} \\
\text { After } 258 \mathrm{hrs:} \\
\text { External: FeO-(Co-Ni) } \\
\text { Subsurface: Chromia } \\
\text { Adjacent to substrate: Chromia; } \\
\text { O-Fe-(Ni-Cr) } \\
\text { After } 524.5 \mathrm{hrs:} \\
\text { External: O-Fe-Ni-Cr } \\
\text { Subsurface: Chromia } \\
\text { Adjacent to substrate: Chromia; } \\
\text { Sulfur sorption }\end{array}$ & $\begin{array}{c}\text { Extensive oxidation resulted; } \\
\text { Separation of oxide from underlying } \\
\text { substrate } \\
\text { Multiple layers: } \\
\sim 6-15 \mu \mathrm{m} \\
\text { After } 259 \mathrm{hrs:} \\
\text { External: } \mathrm{FeO}-(\mathrm{Co}-\mathrm{Ni}) \\
\text { Subsurface: O-Fe-Cr-(Co-Ni) } \\
\text { Adjacent to substrate: O-Cr-Co-Fe } \\
\text { After 476 hrs: } \\
\text { External: O-Fe-(Ni-Co) } \\
\text { Co } \\
\text { Subsurface: O-Fe-Cr-(Ni-Co); O-Cr- } \\
\text { Precipitates: O-Co-(Fe) } \\
\text { Adjacent to substrate: O-Cr-(Co) } \\
\text { spinel } \\
\text { After 986 hrs: } \\
\text { Extensive oxidation }\end{array}$ & $\begin{array}{c}\text { Extensive oxidation resulted: } \\
\sim 6-18 \mu \mathrm{m} \\
\text { Separation of internal oxide layer } \\
\text { adjacent to substrate from the } \\
\text { surrounding external oxide } \\
\text { After } 253 \mathrm{hrs}: \\
\text { External: O-Fe-Co-(Cr-Ni) } \\
\text { Subsurface: O-Fe-(Co-Ni-Cr) } \\
\text { Precipitates: O-Cr-Ni } \\
\text { Adjacent to substrate: } \mathrm{O}-\mathrm{Cr}-(\mathrm{Fe}-\mathrm{Co}- \\
\text { Ni) or O-Cr-Co } \\
\text { After } 546.5 \mathrm{hrs:} \\
\text { External: } \mathrm{O}-\mathrm{Cr}-(\mathrm{Fe}) \\
\text { Subsurface: } \mathrm{O}-\mathrm{Cr}-(\mathrm{Fe}) \\
\text { Adjacent to substrate: O-Cr } \\
\text { After 1014 hrs: } \\
\text { External: O-Fe-(Co) } \\
\text { Subsurface: O-Fe-(Ni) } \\
\text { Precipitate: } \mathrm{O}-\mathrm{Cr}-(\mathrm{Ni}-\mathrm{Fe}) \\
\text { Adjacent to substrate: } \mathrm{O}-\mathrm{Cr}-(\mathrm{Co}) \\
\end{array}$ & $\begin{array}{c}\text { Extensive oxidation resulted after } 225 \mathrm{hrs} \text {. } \\
\text { Thickness of the external oxide was } \\
\sim 8-13 \mu \mathrm{m} \\
\text { External: O-Fe-(Co-Ni-Cr) } \\
\text { Subsurface: O-Cr } \\
\text { After } 496 \text { hrs, extensive oxidation } \\
\text { resulted. The thickness of the oxide was } \\
\sim 7.5-20 \mu \mathrm{m} \text {. } \\
\text { External: O-Co-Cr-Fe } \\
\text { Subsurface: } \mathrm{O}-\mathrm{Cr}\end{array}$ \\
\hline Internal Oxidation* & & $\begin{array}{c}\text { Intermittently observed along } \\
\text { the periphery of the fibers; } \\
\text { Depth of penetrations: } \sim 5-8 \mu \mathrm{m} \text {; } \\
\text { Also intermittently observed } \\
\text { entirely throughout the fiber; } \\
\text { Possible grain boundary } \\
\text { oxidation } \\
\text { Oxidation along adjacent sinter } \\
\text { bonded fibers } \\
\text { Sulfur sorption within cross- } \\
\text { sectioned fiber }\end{array}$ & $\begin{array}{l}\text { With time, the extent of internal oxidation } \\
\text { within the fiber increased } \\
\text { After } 259 \text { hrs, intermittent oxidation was } \\
\text { observed across the fiber; Intergranular } \\
\text { oxidation was evident; Oxidation resulted } \\
\text { along adjacent sinter bonded fibers } \\
\text { After } 476 \text { hrs, significant oxidation resulted } \\
\text { along the periphery of the base metal of the } \\
\text { fiber } \\
\text { After } 986 \text { hrs, significant oxidation resulted } \\
\text { across the entire surface of the cross- } \\
\text { sectioned fibers }\end{array}$ & $\begin{array}{l}\text { After } 253 \text { hrs, extensive internal oxidation } \\
\text { resulted along the periphery of the fiber, } \\
\text { extending to depths of } 2.5 \mu \mathrm{m} ; \\
\text { Intermittently, oxidation was observed } \\
\text { entirely throughout the cross-sectioned } \\
\text { fiber } \\
\text { After } 546.5 \text { hrs, extensive internal } \\
\text { oxidation was observed across the entire } \\
\text { cross-sectioned fiber } \\
\text { After } 1014 \text { hrs, extensive oxidation was } \\
\text { observed across the entire cross-sectioned } \\
\text { fiber; Internal oxides detected }\end{array}$ & $\begin{array}{l}\text { Oxidation observed along sinter bond } \\
\text { formed between adjacent fibers } \\
\text { After } 225 \mathrm{hrs} \text {, extensive oxidation resulted } \\
\text { across the entire fiber cross-sectioned } \\
\text { surface; Alternately penetration to depths } \\
\text { of } \sim 5 \mu \mathrm{m} \text { was observed along the } \\
\text { periphery of the fibers } \\
\text { After } 496 \mathrm{hrs,} \mathrm{extensive} \mathrm{internal} \mathrm{oxidation} \\
\text { was observed along the entire cross- } \\
\text { sectioned surface of the fibers }\end{array}$ \\
\hline $\begin{array}{l}\text { Recommendation for } \\
\text { PFBC Use }\end{array}$ & $\begin{array}{l}\text { Possible short-term } \\
\text { use }\end{array}$ & No & No & No & No \\
\hline
\end{tabular}

\begin{tabular}{|c|c|c|c|c|}
\hline $\begin{array}{c}\mathbf{6 5 0}^{\circ} \mathrm{C} \\
\left(1200^{\circ} \mathrm{F}\right)\end{array}$ & $\begin{array}{c}760^{\circ} \mathrm{C} \\
\left(1400^{\circ} \mathrm{F}\right)\end{array}$ & $\begin{array}{c}815-840{ }^{\circ} \mathrm{C} \\
\left(1500-15500^{\circ} \mathrm{F}\right)\end{array}$ & $\begin{array}{c}8^{840} 0^{\circ} \mathrm{C}\left(1550^{\circ} \mathrm{F}\right) \\
-\mathrm{NoSO}_{2}-\end{array}$ & $\begin{array}{l}840^{\circ} \mathrm{C}\left(1550^{\circ} \mathrm{F}\right) \\
-\mathrm{SO}_{2} \& \mathrm{Na}-\end{array}$ \\
\hline and $500 \mathrm{Hrs}$ & 258, 524.5, and $1016 \mathrm{Hrs}$ & 259, 476, and $986 \mathrm{Hrs}$ & 253, 546.5, and 1014 Hrs & 225 and $496 \mathrm{Hrs}$ \\
\hline
\end{tabular}




\begin{tabular}{|c|c|c|c|c|c|}
\hline \multirow{2}{*}{$\begin{array}{c}\text { USF Hastelloy } \mathbf{X} \\
47 \% \mathrm{Ni}, 22 \% \mathrm{Cr}, 19 \% \mathrm{Fe}, \\
9 \% \mathrm{Mo}, 1.7 \% \mathrm{Co}, 0.6 \% \mathrm{~W}, \\
0.5 \% \mathrm{Mn}, 0.3 \% \mathrm{Si}, 0.08 \% \mathrm{C}\end{array}$} & \multicolumn{5}{|c|}{ Simulated PFBC Operating Conditions } \\
\hline & $\begin{array}{c}650^{\circ} \mathrm{C} \\
\left(1200^{\circ} \mathrm{F}\right) \\
242 \text { and } 500 \mathrm{Hrs}\end{array}$ & $\begin{array}{c}760^{\circ} \mathrm{C} \\
\left(1400^{\circ} \mathrm{F}\right) \\
258,524.5 \text {, and } 1016 \mathrm{Hrs}\end{array}$ & $\begin{array}{c}815-840^{\circ} \mathrm{C} \\
\left(1500-1550^{\circ} \mathrm{F}\right) \\
259,476, \text { and } 986 \mathrm{Hrs}\end{array}$ & $\begin{array}{c}840^{\circ} \mathrm{C}\left(1550^{\circ} \mathrm{F}\right) \\
-\mathrm{No} \mathrm{SO}_{2}- \\
253,546.5 \text {, and } 1014 \mathrm{Hrs}\end{array}$ & $\begin{array}{l}840^{\circ} \mathrm{C}\left(1550^{\circ} \mathrm{F}\right) \\
-\mathrm{SO}_{2} \& \mathrm{Na}- \\
225 \text { and } 496 \mathrm{Hrs}\end{array}$ \\
\hline Physical Integrity & Intact & Intact & Intact & Intact & $\begin{array}{l}\text { Expansion and separation of filtration media } \\
\text { radiating from the circumferentially welded } \\
\text { metal joiner rings within } 496 \text { hrs (i.e., } \\
\text { elephant foot formation); Longitudinal cracks } \\
\text { within filter media; Embrittlement and } \\
\text { cracking of the filtration media }\end{array}$ \\
\hline Open Porosity* & Retained after $242-500 \mathrm{hr}$ & $\begin{array}{l}\text { Retained. Localized areas of pore } \\
\text { closure after } 258-1016 \mathrm{hrs}\end{array}$ & $\begin{array}{l}\text { Retained. Localized areas of } \\
\text { pore closure after } 986 \mathrm{hrs}\end{array}$ & $\begin{array}{c}\text { Pore closure resulted after } \\
546.5-1014 \mathrm{hr} \\
\end{array}$ & $\begin{array}{l}\text { Extensive pore closure restricted porosity } \\
\text { after } 225-496 \mathrm{hrs}\end{array}$ \\
\hline Surface Oxidation* & $\begin{array}{c}0.6 \mu \mathrm{m} \text { after } 242 \mathrm{hrs} ; \sim 4 \mu \mathrm{m} \\
\text { after } 500 \mathrm{hrs} \\
\\
\text { External: O-Ni-Fe-Cr } \\
\text { Crack formations evident } \\
\text { within this layer } \\
\text { Ni-chromate subsurface layer }\end{array}$ & $\begin{array}{l}\text { 3.75-6.6 } \mu \mathrm{m} \text { oxidation layer } \\
\text { External O-Fe-Ni-Cr spinel, and } \\
\text { underlying chromia-enriched } \\
\text { layer }\end{array}$ & $\begin{array}{l}1.6-4.3 \mu \mathrm{m} \text { oxidation layer } \\
\text { After } 259 \mathrm{hrs}: \\
\text { External: O-Cr-Ni-Fe spinel; } \\
\text { Chromia subsurface } \\
\text { After } 476 \mathrm{hrs:} \text { O-Fe-Ni/Cr- } \\
\text { rich spinel } \\
\text { Chromia subsurface } \\
\text { After } 986 \text { hrs: } \\
\text { O-Ni-Fe-Cr } \\
\text { Chromia subsurface }\end{array}$ & $\begin{array}{c}\text { Along discrete fibers, the } \\
\text { oxidation layer ranged between } \\
\sim 2.7-4.2 \mu \mathrm{m} \\
\\
\text { External: Spinels } \\
\text { (O-Cr-Ni-Fe; O-Fe-Ni-Cr) } \\
\text { Chromia subsurface }\end{array}$ & $\begin{array}{l}\text { Along discrete fibers, the oxidation layer } \\
\text { ranged between } \sim 1.8-2.5 \mu \mathrm{m} \\
\text { External: O-Ni-Cr-Fe spinel } \\
\text { Chromia subsurface } \\
\text { Low concentrations of sulfur detected in } \\
\text { subsurface chromia layer }\end{array}$ \\
\hline Internal Oxidation* & Negligible/limited & $\begin{array}{c}\text { Internal oxidation along the } \\
\text { periphery of the fiber, and along } \\
\text { the sinter bond between adjacent } \\
\text { fibers }\end{array}$ & $\begin{array}{l}\text { Internal oxidation along the } \\
\text { periphery of the fiber, and } \\
\text { along the sinter bond between } \\
\text { adjacent fibers }\end{array}$ & $\begin{array}{l}\text { Evident along the periphery of } \\
\text { the fiber, and along the sinter } \\
\text { bond between adjacent fiber; } \\
\text { Extensive after } 546.5 \mathrm{hr}\end{array}$ & $\begin{array}{l}\text { Extensive internal oxidation after 225- } \\
496 \mathrm{hrs}\end{array}$ \\
\hline $\begin{array}{l}\text { Recommendation for } \\
\text { PFBC Use }\end{array}$ & Yes & $\begin{array}{l}\text { Possible short-term use; Integrity } \\
\text { of the fibers questioned with } \\
\text { extended operating time }\end{array}$ & $\begin{array}{l}\text { Possible short-term use; } \\
\text { Integrity of the fibers } \\
\text { questioned due to crack } \\
\text { formations resulting } \\
\text { throughout the oxide layer } \\
\text { formed on the o.d. and i.d. } \\
\text { filter surfaces }\end{array}$ & $\begin{array}{l}\text { No } \\
\text { Crack formations within the } \\
\text { oxide along the i.d. surface } \\
\text { after } 546.5 \text { hrs }\end{array}$ & No \\
\hline
\end{tabular}

* Based on SEM/EDX analyses. 


\begin{tabular}{|c|c|c|c|c|c|}
\hline \multirow{2}{*}{$\begin{array}{c}\text { Pall Hastelloy X } \\
\\
47 \% \mathrm{Ni}, 22 \% \mathrm{Cr}, 19 \% \mathrm{Fe}, \\
9.0 \% \mathrm{Mo}, 1.7 \% \mathrm{Co}, 0.6 \% \mathrm{~W}, \\
0.5 \% \mathrm{Mn}, 0.3 \% \mathrm{Si}, 0.08 \% \mathrm{C}\end{array}$} & \multicolumn{5}{|c|}{ Simulated PFBC Operating Conditions } \\
\hline & $\begin{array}{c}650^{\circ} \mathrm{C} \\
\left(1200^{\circ} \mathrm{F}\right) \\
242 \text { and } 500 \mathrm{Hrs} \\
\end{array}$ & $\begin{array}{c}760^{\circ} \mathrm{C} \\
\left(1400^{\circ} \mathrm{F}\right) \\
258,524.5 \text {, and } 1016 \mathrm{Hrs} \\
\end{array}$ & $\begin{array}{c}815-8400^{\circ} \mathrm{C} \\
\left(1500-1550^{\circ} \mathrm{F}\right) \\
259,476, \text { and } 986 \mathrm{Hrs} \\
\end{array}$ & $\begin{array}{c}840^{\circ} \mathrm{C}\left(1550^{\circ} \mathrm{F}\right) \\
-\mathrm{No} \mathrm{SO}_{2}- \\
253,546.5 \text {, and } 1014 \mathrm{Hrs}\end{array}$ & $\begin{array}{l}840^{\circ} \mathrm{C}\left(1550^{\circ} \mathrm{F}\right) \\
-\mathrm{SO}_{2} \& \mathrm{Na}- \\
225 \text { and } 496 \mathrm{Hrs} \\
\end{array}$ \\
\hline Physical Integrity & Intact & Intact & Intact & Intact & Surface scaling \\
\hline Open Porosity* & Retained after $242 \mathrm{hrs}$ & Retained & Retained & Retained & Generally retained \\
\hline Surface Oxidation* & $\begin{array}{l}\sim 4 \mu \mathrm{m} \text { oxide intermittently } \\
\text { formed along the outer surface } \\
\text { of the particles } \\
\\
\text { After } 242 \mathrm{hrs:} \\
\text { External: Ni-Cr-Fe-O } \\
\text { contained numerous cracks } \\
\text { Subsurface: Continuous nickel } \\
\text { chromate phase }\end{array}$ & $\begin{array}{c}\text { Multiple layers } \\
\text { After } 258 \text { hrs: } \\
\text { o.d.surface: } \sim 6 \mu \mathrm{m} \\
\text { External: O-Ni-Fe } \\
\text { Subsurface: Chromia } \\
\text { Mid-section: Intermittent } \\
\text { i.d. surface: } \sim 4.3-5.7 \mu \mathrm{m} \\
\text { External : NiO } \\
\text { Subsurface: O-Fe-Ni } \\
\text { Interface: Chromia } \\
\text { After } 524.5 \text { hrs } \\
\text { o.d. surface } \\
\text { External: O-Ni-Fe } \\
\text { Subsurface: Chromia } \\
\text { i.d. surface } \\
\text { External: O-Cr-Ni } \\
\text { Interface: Chromia } \\
\text { After 1016 hrs } \\
\text { o.d surface: } 2.8-5 \text { rm } \\
\text { External: O-Cr-Ni } \\
\text { Subsurface: Chromia } \\
\text { i.d. surface: } \sim 3.5-8.75 \mu \mathrm{m} \\
\text { External: O-Ni-Fe-Cr } \\
\text { Subsurface: CCromia }\end{array}$ & $\begin{array}{l}\text { Multiple layers } \\
\\
\text { After } 259 \text { hrs: } \\
\sim 2.4 \mu \mathrm{m} \text { on o.d. } \\
\sim 4 \mu \mathrm{m} \text { on i.d. } \\
\text { External: O-Ni-Fe } \\
\text { Interface: Chromia } \\
\\
\text { After } 476 \text { hrs: } \\
\sim 8-10 \mu \mathrm{m} \text { on o.d. } \\
\\
\text { After } 986 \text { hrs: } \\
\sim 9 \mu \mathrm{m} \text { on o.d.; } \\
\sim 5-9 \mu \mathrm{m} \text { on i.d } \\
\text { External: O-Fe-Ni } \\
\text { Interface: Chromia }\end{array}$ & $\begin{array}{l}\text { Multiple layers } \\
\text { After } 253 \text { hrs: } \sim 2-4 \mu \mathrm{m} \\
\text { o.d. surface: Chromia } \\
\text { Mid-Section: } \\
\text { External: O-Ni-Fe } \\
\text { Subsurface: Chromia } \\
\text { i.d surface: } \\
\text { Separation of oxide layers } \\
\text { After } 546.5 \text { hrs: } \sim 2.6-3.4 \mu \mathrm{m} \\
\text { o.d. surface: Chromia } \\
\text { i.d surface: Crack formations } \\
\text { throughout the oxide; Removal } \\
\text { of oxide } \\
\text { After } 1014 \text { hrs } \\
\text { o.d. surface: } \sim 16-20 \mu \mathrm{m} \\
\text { External : O-Fe-Ni } \\
\text { Subsurface: Chromia } \\
\text { i.d. surface: } \sim 3 \mu \mathrm{m} \\
\text { Crack formations throughout } \\
\text { the oxide; Removal of oxide } \\
\text { Pulse cycling reduced the } \\
\text { adherence and integrity of the } \\
\text { oxide formation to remain } \\
\text { attached to the base metal } \\
\text { substrate particle }\end{array}$ & $\begin{array}{l}\text { Multiple layers } \\
\text { After } 225 \mathrm{hrs:} \\
\text { o.d. surface: Continuous oxide formation } \\
\text { External : } \sim 2.5-8.8 \mu \mathrm{m} \text { O-Fe-Ni } \\
\text { Subsurface: } \sim 1.8-5 \mu \mathrm{m} \text { Chromia } \\
\text { After } 496 \mathrm{hrs:} \\
\text { o.d. surface : } \\
\text { External : } \sim 6.5-8.5 \mu \mathrm{m} \text { O-Fe-Ni } \\
\text { Subsurface: } \sim 1.6-4 \mu \mathrm{m} \text { Chromia } \\
\text { Near the center of the cross-sectioned filter } \\
\text { wall, and particularly along the i.d., crack } \\
\text { formations were readily evident through the } \\
\text { oxide; Where present, the thickness of the } \\
\text { residual chromia oxide was } \sim 2-5 \mu \mathrm{m} \\
\text { Removal of the external oxide from the } \\
\text { chromia-enriched surface was expected to } \\
\text { have resulted along the i.d. surface of the } \\
\text { filter material after } 496 \text { hrs }\end{array}$ \\
\hline Internal Oxidation* & Limited/negligible & $\begin{array}{c}\text { Internal oxidation, and oxidation } \\
\text { along the grain boundaries evident } \\
\text { after } 524.5 \mathrm{hrs}\end{array}$ & $\begin{array}{l}\text { Internal oxidation along the } \\
\text { periphery of the particles } \\
\text { evident after } 259 \mathrm{hr} \text {, and } \\
\text { tended to increase with time; } \\
\text { Oxidation also observed } \\
\text { along the grain boundaries } \\
\text { evident after } 259 \mathrm{hrs} \\
\end{array}$ & $\begin{array}{l}\text { Internal oxidation along the } \\
\text { periphery of the particles, as } \\
\text { well as along the sinter bonds } \\
\text { observed after } 253 \mathrm{hrs} \text {; Internal } \\
\text { oxidation became more } \\
\text { pronounced with extended } \\
\text { exposure time } \\
\end{array}$ & $\begin{array}{l}\text { After } 225-496 \text { hrs, internal oxidation along } \\
\text { the periphery of the particles, and along the } \\
\text { sinter bonds between adjacent particles was } \\
\text { observed }\end{array}$ \\
\hline $\begin{array}{l}\text { Recommendation for } \\
\text { PFBC Use }\end{array}$ & Yes & 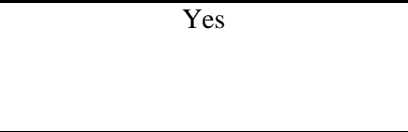 & $\begin{array}{l}\text { Yes; Stability of matrix } \\
\text { questioned with extended } \\
\text { exposure time }\end{array}$ & $\begin{array}{l}\text { Possible short-term use; } \\
\text { Integrity of the particles } \\
\text { questioned with extended } \\
\text { operating time }\end{array}$ & $\begin{array}{l}\text { Yes; Stability of matrix questioned with } \\
\text { extended exposure time }\end{array}$ \\
\hline
\end{tabular}

* Based on SEM/EDX analyses. 


\begin{tabular}{|c|c|c|c|c|c|}
\hline \multirow[b]{2}{*}{$\begin{array}{c}\mathrm{Ni} \mathrm{Bal} ; 15.5 \% \mathrm{Cr}, 8 \% \mathrm{Fe} \\
0.3 \% \mathrm{Mn}, 0.2 \% \mathrm{Si}, 0.2 \% \mathrm{Al} \\
0.2 \% \mathrm{Ti}\end{array}$} & \multicolumn{5}{|c|}{ Simulated PFBC Operating Conditions } \\
\hline & $\begin{array}{c}650^{\circ} \mathrm{C} \\
\left(1200^{\circ} \mathrm{F}\right) \\
242 \text { and } 500 \mathrm{Hrs}\end{array}$ & $\begin{array}{c}760^{\circ} \mathrm{C} \\
\left(1400^{\circ} \mathrm{F}\right) \\
\\
\text { 258, 524.5, and } 1016 \mathrm{Hrs}\end{array}$ & $\begin{array}{c}815-840^{\circ} \mathrm{C} \\
\left(1500-1550^{\circ} \mathrm{F}\right) \\
259,476, \text { and } 986 \mathrm{Hrs}\end{array}$ & $\begin{array}{c}840^{\circ} \mathrm{C}\left(1550^{\circ} \mathrm{F}\right) \\
-\mathrm{No} \mathrm{SO}_{2}- \\
253,546.5 \text {, and } 1014 \text { Hrs }\end{array}$ & $\begin{array}{l}8^{840^{\circ} \mathrm{C}\left(1550^{\circ} \mathrm{F}\right)} \\
-\mathrm{SO}_{2} \& \mathrm{Na}- \\
225 \text { and } 496 \mathrm{Hrs}\end{array}$ \\
\hline Physical Integrity & Intact & Intact & Intact & Intact & Intact; Densified external surface \\
\hline Open Porosity* & $\begin{array}{l}\text { Retained after } 242 \text { hrs; Limited } \\
\text { after } 500 \text { hrs of operation }\end{array}$ & $\begin{array}{l}\text { Retained. Localized area of } \\
\text { external surface pore closure after } \\
524.5-1016 \mathrm{hrs}\end{array}$ & $\begin{array}{l}\text { Localized areas of external } \\
\text { surface pore closure after } \\
259-986 \mathrm{hrs}\end{array}$ & $\begin{array}{c}\text { Localized areas of external } \\
\text { surface pore closure after } 253 \text { - } \\
546.5 \mathrm{hrs} \text {; Continuous } \\
\text { amorphous external surface } \\
\text { oxide layer formed after } \\
1014 \mathrm{hrs} \\
\end{array}$ & Extensive pore closure after $225-496 \mathrm{hrs}$ \\
\hline Surface Oxidation* & $\begin{array}{l}\text { Multiple layers: } \\
\qquad \sim 8-11 \mu \mathrm{m} \\
\text { External: } \sim 2 \mu \mathrm{m} \text { thick O-Ni-Fe } \\
\text { or O-Ni layer; Sulfur identified } \\
\text { to be present within the NiO } \\
\text { layer, forming a filament-like } \\
\text { structure } \\
\text { Subsurface: } \sim 8 \mu \mathrm{m} \text { nickel } \\
\text { chromate layer } \\
\text { Along the o.d. surface of the } \\
\text { filtration media, removal of the } \\
\text { oxide from the fibers was } \\
\text { observed; Retention of the } \\
\text { oxide along the i.d. surface } \\
\text { resulted }\end{array}$ & $\begin{array}{c}\sim 1.5 \mu \mathrm{m} \text { after } 258 \mathrm{hrs} ; ~ \\
\text { after } 1016 \mathrm{hrs} \\
\text { External: Chromia/Ni-O or } \\
\text { chrome-nickel spinel after } 258 \mathrm{hrs} \\
\\
\text { Fe/Ni-O formed along the outer } \\
\text { surface of the continuous oxide } \\
\text { layer; Subsurface chromia; Crack } \\
\text { formations intermittently } \\
\text { observed } \\
\text { After } 1016 \text { hrs, NiO formed along } \\
\text { the outer surface of the } \\
\text { continuous oxide; Subsurface Fe- } \\
\text { Ni-O spinel and nickel chromate } \\
\text { phases }\end{array}$ & $\begin{array}{c}\text { Multiple layers: } \\
\sim 7.6 \mu \mathrm{m} \text { after } 259 \mathrm{hrs} \\
\sim 4-7.2 \mu \mathrm{m} \text { after } 476 \mathrm{hrs} ; \\
\sim 8-10 \mu \mathrm{m} \text { after } 986 \mathrm{hrs} \\
\\
\text { External: } \mathrm{NiO} \\
\text { Subsurface: O-Ni-Fe, O-Ni, } \\
\text { O-Ni-Cr, O-Cr-Ni } \\
\text { Crack formations were } \\
\text { observed within the external } \\
\text { oxide layer after } 259 \mathrm{hrs}\end{array}$ & $\begin{array}{c}\text { Multiple layers: } \\
\sim 6.25 \mu \mathrm{m} \text { after } 253 \mathrm{hrs} ; \\
\sim 7.5 \mu \mathrm{m} \text { after } 546.5 \mathrm{hrs} ; \\
\sim 8.3-10 \mu \mathrm{m} \text { after } 1014 \mathrm{hrs} \\
\\
\text { External: Ni/NiO } \\
\text { Subsurface: Nickel chromate; } \\
\text { Chromia } \\
\text { Crack formations within, and } \\
\text { separation of the external oxide } \\
\text { phase from the underlying } \\
\text { subsurface oxides evident after } \\
253 \mathrm{hrs}\end{array}$ & $\begin{array}{l}\text { Extensive oxidation of the fibers resulting in } \\
\text { pore closure and restriction of gas flow } \\
\text { through the filter media } \\
\text { A continuous, amorphous, } \mathrm{Ni} / \mathrm{NiO} \text {-enriched } \\
\text { layer formed along the o.d. surface of the } \\
\text { filter element } \\
\text { Along discrete, sinter bonded fibers, cracks } \\
\text { were observed through the } ~ 6.7 \mu \mathrm{m} \text { thick } \\
\text { surface oxide } \\
\text { External: O-Ni/Fe } \\
\text { Subsurface: } \mathrm{Ni} / \mathrm{NiO}, \mathrm{O}-\mathrm{Ni}-\mathrm{Cr} / \mathrm{Fe}, \mathrm{O}-\mathrm{Ni}-\mathrm{Cr} \\
\text { Adjacent to substrate: } \mathrm{Chromia}\end{array}$ \\
\hline Internal Oxidation* & Negligible & $\begin{array}{c}\text { Internal oxidation initially along } \\
\text { the periphery of the fiber; } \\
\text { Extensive oxidation with } \\
\text { extended time } \\
\end{array}$ & $\begin{array}{c}\text { Internal oxidation along the } \\
\text { periphery of the fiber, as well } \\
\text { as within the cross-sectioned } \\
\text { fiber }\end{array}$ & $\begin{array}{c}\text { Void formations through the } \\
\text { cross-sectioned fiber, } \\
\text { increasing with extended } \\
\text { operating time } \\
\end{array}$ & $\begin{array}{c}\text { Within discrete fibers, void formations were } \\
\text { evident along the cross-sectioned fiber } \\
\text { surface }\end{array}$ \\
\hline $\begin{array}{l}\text { Recommendation for } \\
\text { PFBC Use }\end{array}$ & $\begin{array}{l}\text { Possible short-term use; } \\
\text { Integrity of the fibers/element } \\
\text { questioned with extended } \\
\text { operating time }\end{array}$ & $\begin{array}{l}\text { Possible short-term use; Integrity } \\
\text { of the fibers/element questioned } \\
\text { with extended operating time }\end{array}$ & $\begin{array}{l}\text { Possible short-term use; } \\
\text { Integrity of the fibers/ } \\
\text { element questioned with } \\
\text { extended operating time }\end{array}$ & $\begin{array}{l}\text { Possible short-term use; } \\
\text { Integrity of the fibers/element } \\
\text { questioned with extended } \\
\text { operating time }\end{array}$ & No \\
\hline
\end{tabular}

* Based on SEM/EDX analyses. 


\begin{tabular}{|c|c|c|c|c|c|}
\hline & \multicolumn{5}{|c|}{ Simulated PFBC Operating Conditions } \\
\hline $\begin{array}{c}\mathrm{Ni} \mathrm{Bal} ; 15.5 \% \mathrm{Cr}, 8 \% \mathrm{Fe} \\
0.3 \% \mathrm{Mn}, 0.2 \% \mathrm{Si}, 0.2 \% \mathrm{Al} \\
0.2 \% \mathrm{Ti}\end{array}$ & $\begin{array}{c}650^{\circ} \mathrm{C} \\
\left(1200^{\circ} \mathrm{F}\right) \\
242 \text { and } 500 \text { Hrs }\end{array}$ & $\begin{array}{c}760^{\circ} \mathrm{C} \\
\left(1400^{\circ} \mathrm{F}\right) \\
258,524.5 \text {, and } 1016 \mathrm{Hrs}\end{array}$ & $\begin{array}{c}\mathbf{8 1 5}-840^{\circ} \mathrm{C} \\
(1500-1550 \\
\\
259,476, \text { and } 986 \text { Hrs }\end{array}$ & $\begin{array}{c}840^{\circ} \mathrm{C}\left(1550^{\circ} \mathrm{F}\right) \\
-\mathrm{No} \mathrm{SO}_{2}- \\
253,546.5, \text { and } 1014 \mathrm{Hrs}\end{array}$ & $\begin{array}{l}840^{\circ} \mathrm{C}\left(1550^{\circ} \mathrm{F}\right) \\
-\mathrm{SO}_{2} \& \mathrm{Na}- \\
225 \text { and } 496 \mathrm{Hrs}\end{array}$ \\
\hline Physical Integrity & Intact & Intact & Intact & Intact & $\begin{array}{l}\text { Crack detected near circumferential weld to } \\
\text { ring with } 225 \mathrm{hrs}\end{array}$ \\
\hline Open Porosity* & Retained after $500 \mathrm{hrs}$ & Retained & $\begin{array}{l}\text { Retained with the exception } \\
\text { of localized areas of pore } \\
\text { closure }\end{array}$ & $\begin{array}{l}\text { Retained with the exception of } \\
\text { localized areas of pore closure } \\
\text { after } 253-546.5 \mathrm{hrs} \text {; Extensive } \\
\text { pore closure after } 1014 \mathrm{hrs}\end{array}$ & $\begin{array}{l}\text { Pore closure resulted along the o.d. surface; } \\
\text { Open porosity was retained throughout the } \\
\text { remainder of the filter wall }\end{array}$ \\
\hline Surface Oxidation* & $\begin{array}{c}\text { After } 242 \text { hrs: } \\
\text { o.d. surface: } \\
\text { External: } \sim 3-3.5 \mu \mathrm{m} \text { Nickel } \\
\text { chromate-iron } \\
\text { Subsurface: } \sim 4.5 \mu \mathrm{m} \mathrm{NiO}, \\
\text { nickel chromate } \\
\text { Thickness of the oxide was not } \\
\text { continuous along the outer } \\
\text { surface of the particle, but } \\
\text { appeared to be preferential to } \\
\text { the direction of the process gas } \\
\text { Mid-section: Limited oxidation } \\
\text { i.d surface : } \sim 3.2 \mu \mathrm{m} \text { oxide } \\
\text { After } 500 \text { hrs: } \\
\sim 1-2 \mu \mathrm{m} \text { along o.d. } \\
\sim 1 \mu \mathrm{m} \text { along mid-section } \\
\sim 2-4 \mu \mathrm{m} \text { along i.d. }\end{array}$ & $\begin{array}{c}\text { Multiple layers } \\
\text { External: NiO } \\
\text { Subsurface: Nickel chromate } \\
\text { Interface: Chromia } \\
\\
\text { Crack formations and debonding } \\
\text { of oxide observed after 258- } \\
1016 \mathrm{hrs} \\
\text { Oxide thickness where retained: } \\
\text { After } 258 \mathrm{hrs:} \sim 3.3 \mu \mathrm{m} \\
\text { After } 524.5 \mathrm{hrs}: \sim 6 \mu \mathrm{m} \\
\text { After } 1016 \mathrm{hrs}: 4-11.7 \mu \mathrm{m}\end{array}$ & $\begin{array}{c}\text { Multiple layers: } \\
\text { External: NiO } \\
\text { Subsurface: Nickel chromate, } \\
\text { O-Fe-Ni, chromia } \\
\text { Interface: NiO } \\
\text { More extensive oxidation } \\
\text { resulted along the o.d. and i.d. } \\
\text { surface of the filter element in } \\
\text { comparison to along the mid- } \\
\text { section } \\
\text { Crack formations were } \\
\text { typically observed through } \\
\text { the oxide; Separation of the } \\
\text { oxide from the base metal } \\
\text { evident after } 986 \text { hrs along } \\
\text { o.d. surface of the filter } \\
\text { element } \\
\text { Oxide thickness: } \\
\text { After } 259 \text { hrs: } \sim 8.3-16.6 \mu \mathrm{m} \\
\text { After } 476 \text { hrs: } \sim 1.6-7.5 \mu \mathrm{m} \\
\text { After } 986 \text { hrs: } \sim 4.6-10 \mu \mathrm{m} \\
\end{array}$ & $\begin{array}{c}\text { Multiple layers } \\
\text { After } 253 \mathrm{hrs:} \\
\text { External: Ni/Cr-O } \\
\text { Subsurface: NiO, Nickel } \\
\text { chromate } \\
\text { Interface: Chromia } \\
\text { After } 546.5 \text { hrs: } \\
\text { External: Nickel chromate } \\
\text { Subsurface: O-Ni-Fe, O-Ni-Cr } \\
\text { Interface: Chromia } \\
\text { After } 1014 \text { hrs: } \\
\text { External: NiO } \\
\text { Subsurface: O-Ni(Fe), O-Cr-Ni } \\
\text { Interface: Chromia } \\
\text { Oxide thickness: } \\
\text { o.d. surface: } ~ 7.2-17.2 \mu \mathrm{m} \\
\text { i.d surface : } ~ 8.8 \mu \mathrm{m}\end{array}$ & $\begin{array}{c}\text { Multiple layers } \\
\text { After } 225 \mathrm{hrs:} \\
\text { o.d. surface: } 2.2 \mu \mathrm{m} \mathrm{Cr} / \mathrm{Ni}-\mathrm{O} \\
\text { i.d. surface: } \sim 0.1-0.26 \mu \mathrm{m} \\
\text { After } 496 \mathrm{hrs:} \\
\text { o.d. surface: } 3 \mu \mathrm{m} \mathrm{Cr}-\mathrm{Fe}-\mathrm{Ni}-\mathrm{O} \\
\text { Mid-section: } \\
\text { Dendritic chromia-enriched whiskers } \\
\text { extended from the surface of the particles; } \\
\text { Subsurface: } \sim 6 \mu \mathrm{m} \mathrm{Cr} / \mathrm{Ni}-\mathrm{O} \\
\text { i.d. surface: } \sim 5 \mu \mathrm{m} \\
\text { External: Nickel chromate } \\
\text { Subsurface: Chromia } \\
\text { Crack formations through the oxide, } \\
\text { separation, and removal of the oxide evident } \\
\text { after } 225 \mathrm{hrs}\end{array}$ \\
\hline Internal Oxidation* & $\begin{array}{l}\text { Limited penetration into } \\
\text { particle after } 500 \text { hrs of } \\
\text { operation }\end{array}$ & $\begin{array}{l}\text { Internal oxidation within and } \\
\text { along the periphery of the } \\
\text { particles, as well as along the } \\
\text { sinter bonds observed after } 258 \\
\text { hr. Tendency to increase with } \\
\text { time, particularly on i.d. surface } \\
\text { of filter media }\end{array}$ & $\begin{array}{l}\text { Extensive internal oxidation } \\
\text { along the periphery of the } \\
\text { base metal resulted after } 259 \\
\text { hr along the o.d. and i.d. } \\
\text { surfaces of the filter element }\end{array}$ & $\begin{array}{l}\text { An internal oxidation zone was } \\
\text { typically present in localized } \\
\text { areas beneath the external } \\
\text { oxide layer } \\
\text { Penetration: } \\
\text { o.d. surface: } \sim 4.8-7.2 \mu \mathrm{m} \\
\text { i.d. surface: } \sim 12-14 \mu \mathrm{m} \\
\text { Internal oxidation within the } \\
\text { particles and along the sinter } \\
\text { bonds more frequently } \\
\text { observed on i.d. surface in } \\
\text { comparison to o.d. or mid- } \\
\text { section of the filter element }\end{array}$ & $\begin{array}{l}\text { Along the o.d. surface of the filter element, } \\
\text { internal oxidation penetrated to depths of } \\
\sim 2.0 \mu \mathrm{m} \text { after } 225 \mathrm{hrs} \text {, and } \sim 10 \mu \mathrm{m} \text { after } \\
\qquad 496 \mathrm{hrs} \\
\text { Internal oxidation was limited along the i.d. } \\
\text { surface of the filter element }\end{array}$ \\
\hline $\begin{array}{l}\text { Recommendation for } \\
\text { PFBC Use }\end{array}$ & Yes & Yes & $\begin{array}{l}\text { Possible short-term use; } \\
\text { Integrity of the particles/ } \\
\text { element questioned with } \\
\text { extended operating time }\end{array}$ & $\begin{array}{l}\text { Possible short-term use; } \\
\text { Integrity of the particles/ } \\
\text { element questioned with } \\
\text { extended operating time }\end{array}$ & $\begin{array}{l}\text { Possible short-term use; Integrity of the } \\
\text { particles/element questioned with extended } \\
\text { operating time }\end{array}$ \\
\hline
\end{tabular}

* Based on SEM/EDX analyses. 
USF 310S

\begin{tabular}{|c|c|c|c|c|c|}
\hline \multirow[b]{2}{*}{$\begin{array}{c}\mathrm{Fe} \mathrm{Bal;} 25 \% \mathrm{Cr}, 20.5 \% \mathrm{Ni} \\
1.6 \% \mathrm{Mn}, 0.75 \% \mathrm{Mo} \\
0.5 \% \mathrm{Si}, 0.05 \% \mathrm{C}\end{array}$} & & & & & \\
\hline & $\begin{array}{c}650^{\circ} \mathrm{C} \\
\left(1200^{\circ} \mathrm{F}\right) \\
242 \text { and } 500 \mathrm{Hrs}\end{array}$ & $\begin{array}{c}760^{\circ} \mathrm{C} \\
\left(1400^{\circ} \mathrm{F}\right) \\
258,524.5 \text {, and } 1016 \text { Hrs }\end{array}$ & $\begin{array}{c}815-840^{\circ} \mathrm{C} \\
\left(1500-1550^{\circ} \mathrm{F}\right) \\
259,476, \text { and } 986 \text { Hrs }\end{array}$ & $\begin{array}{c}8^{840} \mathrm{C}\left(1550^{\circ} \mathrm{F}\right) \\
-\mathrm{No} \mathrm{SO}_{2}- \\
253,546.5 \text {, and } 1014 \mathrm{Hrs}\end{array}$ & $\begin{array}{l}840^{\circ} \mathrm{C}\left(1550^{\circ} \mathrm{F}\right) \\
-\mathrm{SO}_{2} \& \mathrm{Na}- \\
225 \text { and } 496 \mathrm{Hrs}\end{array}$ \\
\hline Physical Integrity & Intact & Intact & Intact & Intact & Intact; Densified external surface \\
\hline Open Porosity* & $\begin{array}{l}\text { Limited open porosity due to } \\
\text { coalescence of fibers after } \\
500 \mathrm{hrs}\end{array}$ & $\begin{array}{l}\text { Localized pore closure; Loss of } \\
\text { open porosity increased with } \\
\text { time particularly along the o.d. } \\
\text { surface of the filter element }\end{array}$ & $\begin{array}{l}\text { Localized pore closure; Loss of } \\
\text { open porosity increased with } \\
\text { time particularly along the o.d. } \\
\text { surface of the filter element }\end{array}$ & $\begin{array}{c}\text { Pore closure restricting gas } \\
\text { flow through the filter element } \\
\text { after } 253-1014 \mathrm{hrs}\end{array}$ & $\begin{array}{l}\text { Pore closure restricting gas flow through the } \\
\text { filter element after } 225-496 \mathrm{hrs}\end{array}$ \\
\hline Surface Oxidation* & $\begin{array}{c}\text { After } 242 \mathrm{hrs} \\
\text { External: } \sim 1 \mu \mathrm{m} \text { Iron oxide } \\
\text { layer } \\
\text { Subsurface: } \sim 1 \mu \mathrm{m} \\
\text { O-Cr-Fe-Ni } \\
\text { After } 500 \mathrm{hrs:} \\
\text { Thicknesses of both external } \\
\text { and subsurface oxides } \\
\text { increased to } \sim 3-5 \mu \mathrm{m} ; \\
\text { Typically cracks extended } \\
\text { through the oxide formations }\end{array}$ & $\begin{array}{c}\text { Extensive oxidation after } 258- \\
1016 \mathrm{hrs} \\
\text { External: FeO, Fe/Ni-Cr-O } \\
\text { Subsurface: Chromia } \\
\text { Oxide thickness: } \\
\text { After } 258 \text { hrs: } \sim 3 \mu \mathrm{m} \\
\text { After } 524.5 \mathrm{hrs:} \sim 6.6-13.3 \mu \mathrm{m} \\
\text { After } 1016 \mathrm{hrs:} \sim 3.5 \mu \mathrm{m} \\
\text { Separation between the oxide } \\
\text { layers, as well as at the base } \\
\text { metal interface } \\
\text { Crack formations observed } \\
\text { through external surface oxide } \\
\text { layer along i.d. surface of the } \\
\text { filter element }\end{array}$ & $\begin{array}{c}\text { Extensive oxidation } \\
\text { External: Fe-Ni-O spinel } \\
\text { Subsurface: Chromia } \\
\text { Separation between the oxide } \\
\text { layers, as well as at the base } \\
\text { metal interface }\end{array}$ & $\begin{array}{c}\text { Extensive oxidation } \\
\text { After } 253 \mathrm{hrs} \\
\text { External: } \mathrm{Fe}-\mathrm{Ni} / \mathrm{Cr}-\mathrm{O} \text { spinel } \\
\text { Subsurface: Chromia } \\
\text { After } 1014 \mathrm{hrs} \\
\text { External: } \mathrm{Fe}-\mathrm{Cr}-\mathrm{O} \\
\text { Subsurface: } \mathrm{Fe}-\mathrm{Cr}-\mathrm{Ni}-\mathrm{O} \text {, } \\
\text { Cr-Fe-O, Ni-Fe-Cr-O } \\
\text { Crack formations within the } \\
\text { oxide(s) observed }\end{array}$ & $\begin{array}{c}\text { Extensive oxidation } \\
\text { Multiple layers } \\
\text { External: Fe-Ni-O spinel } \\
\text { Subsurface: } \mathrm{FeO}, \mathrm{Fe}-\mathrm{Ni} / \mathrm{Cr}-\mathrm{O} \\
\\
\text { Primarily along the i.d. surface of the filter } \\
\text { element, cracks were observed within the } \\
\text { oxide formations, as well as between } \\
\text { adjacent sinter bonded fibers }\end{array}$ \\
\hline Internal Oxidation* & Negligible & $\begin{array}{l}\text { Extensive internal oxidation } \\
\text { along the periphery, as well as } \\
\text { within the fibers, and at the } \\
\text { sinter bonds }\end{array}$ & Extensive internal oxidation & Extensive internal oxidation & Extensive internal oxidation \\
\hline $\begin{array}{l}\text { Recommendation for } \\
\text { PFBC Use }\end{array}$ & $\begin{array}{l}\text { Acceptable for short-term use; } \\
\text { Integrity of the particle } \\
\text { questioned with extended } \\
\text { exposure time }\end{array}$ & No & No & No & No \\
\hline
\end{tabular}

* Based on SEM/EDX analyses.

Simulated PFBC Operating Conditions 
Pall 310S

\begin{tabular}{|c|c|c|c|c|c|}
\hline $\begin{array}{c}\mathrm{Fe} \mathrm{Bal;} 25 \% \mathrm{Cr}, 20.5 \% \mathrm{Ni} \\
1.6 \% \mathrm{Mn}, 0.75 \% \mathrm{Mo} \\
0.5 \% \mathrm{Si}, 0.05 \% \mathrm{C}\end{array}$ & $\begin{array}{c}650^{\circ} \mathrm{C} \\
\left(1200^{\circ} \mathrm{F}\right) \\
242 \text { and } 500 \text { Hrs }\end{array}$ & $\begin{array}{c}\mathbf{7 6 0}^{\circ} \mathrm{C} \\
\left(1400^{\circ} \mathrm{F}\right) \\
\\
\text { 258, 524.5, and } 1016 \mathrm{Hrs}\end{array}$ & $\begin{array}{c}815-840^{\circ} \mathrm{C} \\
\left(1500-1550^{\circ} \mathrm{F}\right) \\
259,476, \text { and } 986 \mathrm{Hrs}\end{array}$ & $\begin{array}{c}840^{\circ} \mathrm{C}\left(1550^{\circ} \mathrm{F}\right) \\
-\mathrm{No} \mathrm{SO}_{2}- \\
253,546.5, \text { and } 1014 \mathrm{Hrs}\end{array}$ & $\begin{array}{l}840^{\circ} \mathrm{C}\left(1550^{\circ} \mathrm{F}\right) \\
-\mathrm{SO}_{2} \& \mathrm{Na}- \\
225 \text { and } 496 \mathrm{Hrs}\end{array}$ \\
\hline Physical Integrity & Intact & $\begin{array}{l}\text { Circumferential failure at metal } \\
\text { ring weld within } 258 \mathrm{hrs}\end{array}$ & $\begin{array}{l}\text { Circumferential failure at metal } \\
\text { ring weld within } 259 \mathrm{hrs}\end{array}$ & $\begin{array}{l}\text { Circumferential failure at metal } \\
\text { ring weld within } 253 \mathrm{hrs}\end{array}$ & $\begin{array}{l}\text { Circumferential failure at metal ring weld } \\
\text { within } 225 \mathrm{hrs}\end{array}$ \\
\hline Open Porosity* & Retained after $242-500 \mathrm{hrs}$ & $\begin{array}{c}\text { Retained } \\
\text { Expected decrease }\end{array}$ & Not characterized & Not characterized & $\begin{array}{l}\text { Extensive pore closure along both outer and } \\
\text { inner external surfaces of the filter element; } \\
\text { Open porosity retained along } \sim 1 \mathrm{~mm} \text { thick } \\
\text { mid-section of the filter element }\end{array}$ \\
\hline Surface Oxidation* & $\begin{array}{c}\text { After } 242 \mathrm{hrs:} \\
\sim 1 \mu \mathrm{m} \text { Cr-Fe-O } \\
\\
\text { After } 500 \mathrm{hrs:} \\
\sim 4-7 \mu \mathrm{m} \text { Chromia; Iron } \\
\text { chromate; Crack formations } \\
\text { were frequently observed, with } \\
\text { spallation, exposing base metal }\end{array}$ & $\begin{array}{c}\text { Multiple oxide layers } \\
\text { After } 258 \text { hrs, } \sim 6 \mu \text { oxide thick } \\
\text { oxide formed } \\
\text { External: Fe-O, Fe-Cr-O } \\
\text { Subsurface: O-Ni-Cr or O-Cr- } \\
\text { Ni-Fe } \\
\text { Interface: Chromia } \\
\text { Frequently the external oxide } \\
\text { was separated from subsurface } \\
\text { spinel layer }\end{array}$ & Not characterized & Not characterized & $\begin{array}{c}\text { Multiple oxide layers } \\
\text { o.d. surface: } \sim 6.6-8.3 \mu \mathrm{m} \text { oxide } \\
\text { External : Fe-O } \\
\text { Subsurface: O-Ni-Fe } \\
\text { Mid-section: } \\
\text { Chromia-enriched whiskers } \\
\text { Interface: Chromia } \\
\text { i.d. surface: } \\
\text { External: Fe-O } \\
\text { Subsurface: Chromia }\end{array}$ \\
\hline Internal Oxidation* & $\begin{array}{c}\text { Limited internal oxidation; } \\
\text { Limited oxidation along sinter } \\
\text { bonds }\end{array}$ & $\begin{array}{l}\text { Along the periphery of the } \\
\text { particles; Within the cross- } \\
\text { sectioned particles }\end{array}$ & Not characterized & Not characterized & $\begin{array}{l}\text { Extensive internal oxidation observed along } \\
\text { both outer and inner surface-contained } \\
\text { particles }\end{array}$ \\
\hline $\begin{array}{c}\text { Recommendation for } \\
\text { PFBC Use }\end{array}$ & $\begin{array}{l}\text { Acceptable for short-term use; } \\
\text { Integrity of the particle } \\
\text { questioned with extended } \\
\text { exposure time }\end{array}$ & Limited short-term use & No & No & No \\
\hline
\end{tabular}

* Based on SEM/EDX analyses. 